\title{
Stakeholder theory in finance : on the financial relevance of nonfinancial stakeholders
}

Citation for published version (APA):

Hann, D. Y. (2011). Stakeholder theory in finance : on the financial relevance of nonfinancial stakeholders. [Doctoral Thesis, Maastricht University]. Maastricht University. https://doi.org/10.26481/dis.20110630dh

Document status and date:

Published: 01/01/2011

DOI:

$10.26481 /$ dis.20110630dh

Document Version:

Publisher's PDF, also known as Version of record

\section{Please check the document version of this publication:}

- A submitted manuscript is the version of the article upon submission and before peer-review. There can be important differences between the submitted version and the official published version of record.

People interested in the research are advised to contact the author for the final version of the publication, or visit the DOI to the publisher's website.

- The final author version and the galley proof are versions of the publication after peer review.

- The final published version features the final layout of the paper including the volume, issue and page numbers.

Link to publication

\footnotetext{
General rights rights.

- You may freely distribute the URL identifying the publication in the public portal. please follow below link for the End User Agreement:

www.umlib.nl/taverne-license

Take down policy

If you believe that this document breaches copyright please contact us at:

repository@maastrichtuniversity.nl

providing details and we will investigate your claim.
}

Copyright and moral rights for the publications made accessible in the public portal are retained by the authors and/or other copyright owners and it is a condition of accessing publications that users recognise and abide by the legal requirements associated with these

- Users may download and print one copy of any publication from the public portal for the purpose of private study or research.

- You may not further distribute the material or use it for any profit-making activity or commercial gain

If the publication is distributed under the terms of Article $25 \mathrm{fa}$ of the Dutch Copyright Act, indicated by the "Taverne" license above, 


\section{STAKEHOLDER THEORY IN FINANCE}

On the Financial Relevance of Nonfinancial Stakeholders 
(C) Daniel Hann, 2011

All rights reserved. No part of this publication may be reproduced, stored in a retrieval system, or transmitted in any form, or by any means, electronic, mechanical, photocopying, recording or otherwise, without the prior permission in writing from the author.

ISBN 978-3-86130-267-4

Cover: Verlagsgruppe Mainz

Printed by Druckerei Mainz, Aachen 


\section{STAKEHOLDER THEORY IN FINANCE}

On the Financial Relevance of Nonfinancial Stakeholders

\section{DISSERTATION}

to obtain the degree of Doctor at

Maastricht University, on the authority of Rector Magnificus,

Prof. mr. G.P.M.F. Mols,

in accordance with the decision of the Board of Deans,

to be defended in public

on Thursday, June 30, 2011, at 12:00 hours

by

DANIEL YONG-KI HANN 


\section{Supervisor}

Prof. dr. R.M.M.J. Bauer

\section{Co-Supervisor}

Dr. J.M.M. Derwall (Maastricht University and Tilburg University)

\section{Assessment Committee}

Prof. dr. P.M.A. Eichholtz (chairman)

Prof. dr. C.G. Koedijk (Tilburg University, The Netherlands)

Prof. dr. F. Moers

This dissertation benefited from the financial support granted by the Maastricht School of Economics of Technology and Organization Research (METEOR), the European Centre for Corporate Engagement (ECCE), and the Foundation for Strategic Environmental Research (MISTRA). 
Dedicated to my parents, for all their love and support. 



\section{Acknowledgments}

Writing this dissertation has allowed me to fulfill many of the goals that I had set out to achieve at the beginning of my Ph.D. It has given me the opportunity to deepen my understanding of finance, broaden my horizons, and learn about myself. When "an expert is a person who has made all the mistakes that can be made in a very narrow field" (Niels Bohr), then the experiences of the last years have certainly brought me closer in my pursuit of becoming one. Nevertheless, reflecting on the many things that I have learned during my Ph.D., I could not agree more with the Will Durant's statement that "education is a progressive discovery of your own ignorance". The process of writing this dissertation would have been a lot more difficult and certainly less enjoyable, were it not for the support and inspiration of the many people that accompanied me along the way. I thus gladly take this opportunity to express my gratitude for their help.

My first words of gratitude are directed at my supervisor, Rob Bauer, who inspired and made it possible for me to pursue a Ph.D. in finance. Rob, without your offer this Ph.D. would have merely remained a daunting consideration of mine and not the great learning experience that I now proudly look back on. I thank you for all your support throughout the process, the freedom you gave me in exploring my own research interests, and your encouragement as well as trust in my capabilities whenever I was doubting my progress. Your friendly supervision, pragmatic advice, and occasional singing of a Neue Deutsche Welle hit have always been greatly appreciated. Thank you for guiding me on this journey!

I want to thank my daily supervisor, Jeroen Derwall, for his kind and tireless support, for sharing his knowledge on sustainable finance with me, and for being a good friend as well as colleague. Jeroen, your enthusiasm for research has been an inspiration, and working with you a challenging as well as pleasant experience. I am grateful for the many discussions, intellectual fistfights, and funny anecdotes that we shared at the office, in bars, or on journeys across the world. Thank you for being a good companion throughout my Ph.D.!

I also want to express my gratitude to Piet Eichholtz, Kees Koedijk, and Frank Moers for agreeing to evaluate my dissertation and their decision to approve it. Piet, thank you for your constructive feedback and advice. Thank you Kees, for helping to lay the foundations of my research by agreeing to make me part of the ECCE program. Who would have thought that buying someone a coffee during a job interview, could turn out to be an investment that lasts one a lifetime? Frank, thank you for your critical views and constructive comments, they were greatly appreciated as was the early opportunity to present my research at your department. At this point, I also like to extend my gratitude to the European Center for Corporate Engagement (ECCE) and the Foundation for Strategic Environmental Research (MISTRA) for providing me with the funding to make this research happen and a broad network to communicate my findings to both an academic and professional audience. 
During my Ph.D. I have greatly benefited from my colleagues and the friendly work environment at the Finance Department of the Maastricht University School of Business and Economics. I thank you all kindly for contributing to a great work experience and for making the department a pleasant place despite the many long hours that I have spent there. My special thanks go to those colleagues who have shared and supported me throughout the highs and lows of the last years: Bart and Thies, as my office mates you were literally there from the start to the finish. I am grateful for the great times that we shared in- and outside the office, and

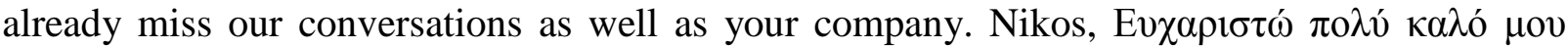
qí $\lambda$ o for your kindness and generosity. "All the world's a stage, and all the men and women merely players...", indeed. Dani, thank you for all the fun that we shared during the Ph.D., for having been the best roommate one can imagine and living proof that working hard and having a good time are not mutually exclusive.

I would also like to make a special mention of Rachel Pownall, Nadja Guenster, Nils Kok, Simone Wies, Michael Viehs, Kathrin Nies, Charlotte Rolef, Julius André, Robin Braun, Piet Eichholtz, Frank Lutgens, Dennis Bams, Stefan Straetmans, Roger Otten, Georges Hübner, Peter Schotman, and Jaap Bos. You have all helped me along the way, and I hope to keep in close contact with you in the future! Many thanks to the ladies of the secretariat (in alphabetical order) - Carina, Cécile, Els, and Francien. You have been extremely supportive over these years, and I will miss our friendly banter.

An important milestone in my Ph.D. program was the time as visiting scholar at the NYU Stern School of Business. I am indebted to Marcin Kacperczyk for inviting me to the Finance Department, for challenging me to dig deeper into my research, and for making this memorable experience possible. I also thank the faculty and Ph.D. students at Stern for sharing their knowledge with me and making me feel welcome throughout my stay.

My biggest thanks go to my family, Ma, Pa, Ben, Ellen, Billie, Mignon and her partner Alex. Without your loving support, faith in me and my decisions, and your encouragement during difficult times this dissertation could not have been completed the way it was. Thank you for being there for me! Finally, I want to thank Clare with all my heart for brightening up the last year of my Ph.D.. Thank you for stepping into my life and turning it upside down, for your love and patience, and for making me a happier person.

In taking my leave from the academic world and looking at the challenges that lie ahead, I feel it is fitting to quote from Wilhelm Meisters Wanderjahre by Goethe (1829):

"Knowing is not enough; we must apply. Willing is not enough; we must do."

Maastricht, June 2011

Daniel Hann 


\section{Contents}

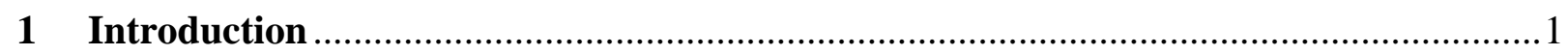

\section{Employee Relations and Credit Risk}

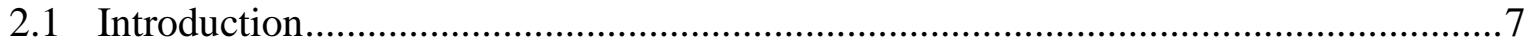

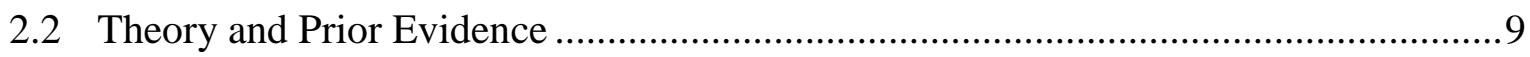

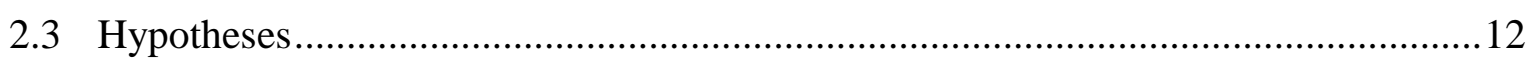

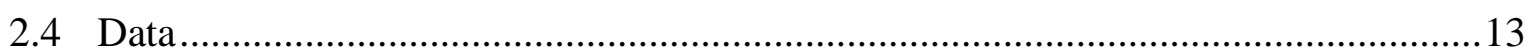

2.4.1 Employee relations...............................................................................13

2.4.2 Credit risk measures...................................................................................... 15

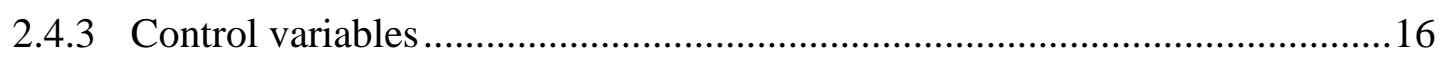

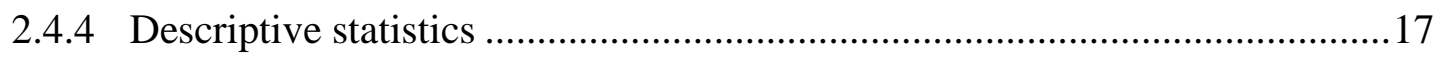

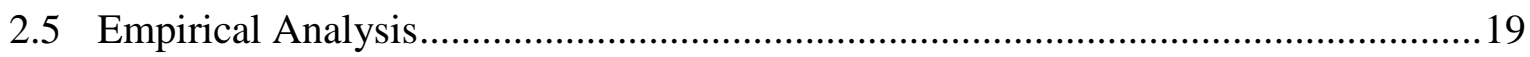

2.5.1 Employee relations and the cost of debt ...................................................... 19

2.5.2 Employee relations and credit ratings ..............................................................21

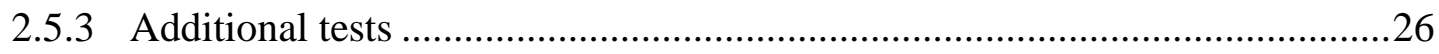

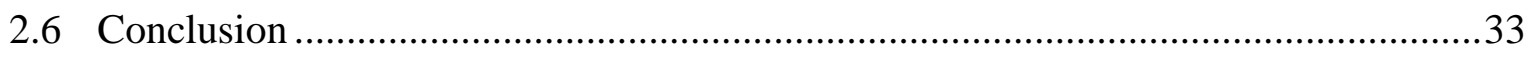

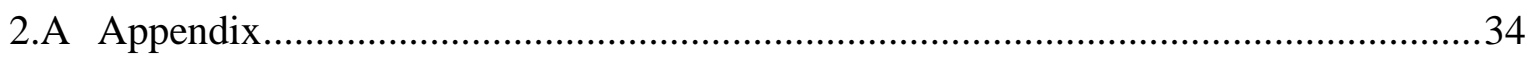

\section{Corporate Environmental Management and Credit Risk}

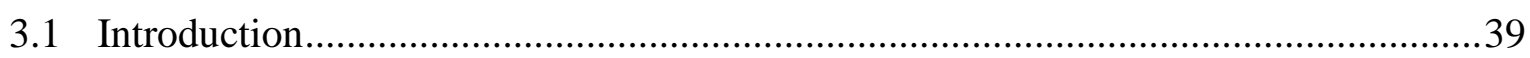

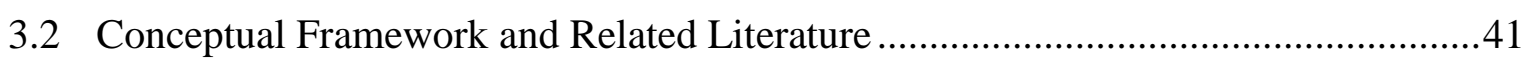

3.2.1 Environmental management and bondholder risk ..........................................4

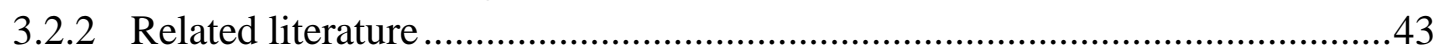

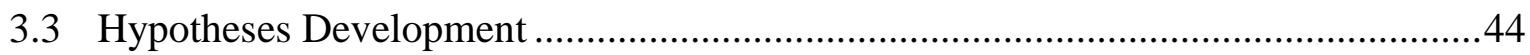

3.4 Data

3.4.1 Environmental management performance ………………………………......4

3.4.2 Credit risk measures....................................................................................

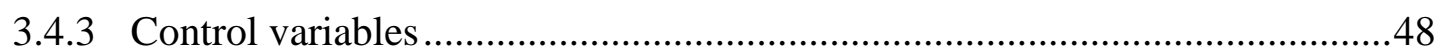

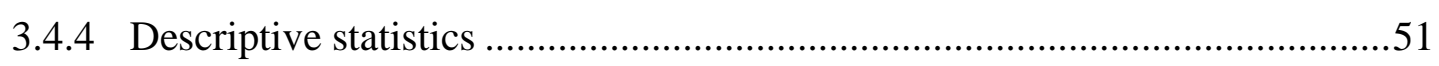

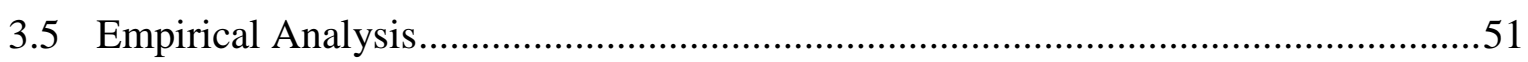

3.5.1 Environmental management and the cost of debt .........................................51

3.5.2 Environmental management and credit ratings.................................................54

3.5.3 Analyzing the effect of individual environmental activities .............................56

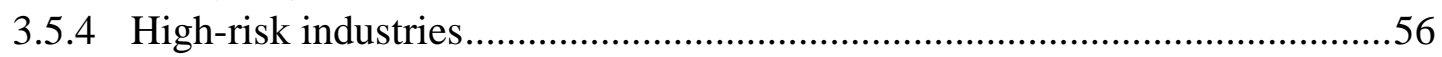

3.5.5 Change in the relevance of environmental management over time.................61

3.5.6 Robustness checks ....................................................................................... 


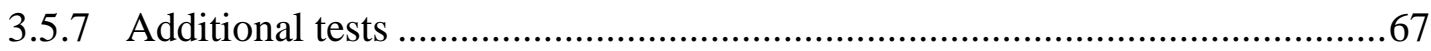

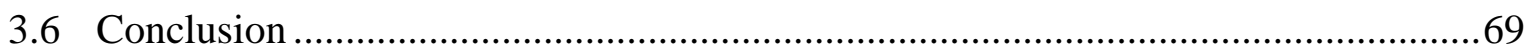

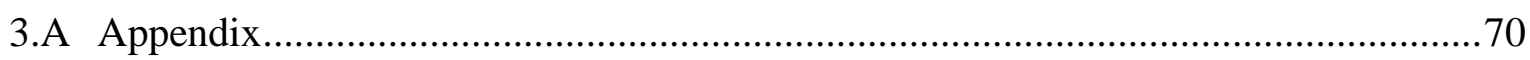

4 Does the Market Misprice Customer Satisfaction?

New Evidence on Errors in Investors' Expectations

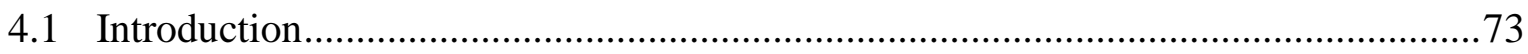

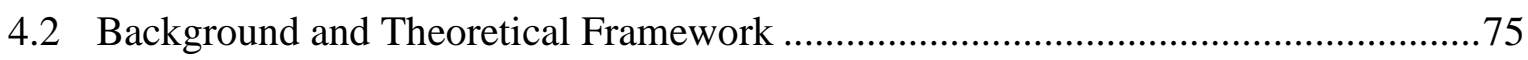

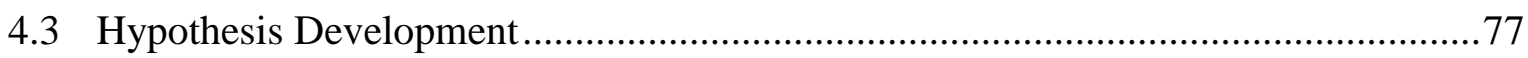

4.3.1 Customer satisfaction and future operating performance .............................77

4.3.2 Customer satisfaction and errors in investors' expectations ...........................78

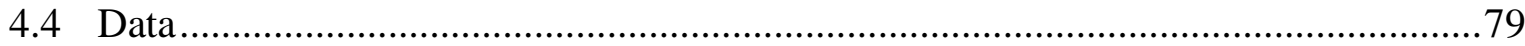

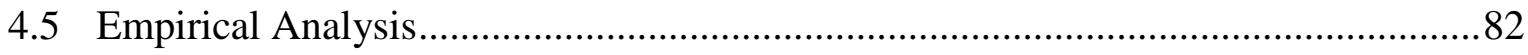

4.5.1 Customer satisfaction and future operating performance .............................82

4.5.2 Customer satisfaction and earnings forecast errors ...................................8 84

4.5.3 Customer satisfaction and earnings announcement returns ...........................8 88

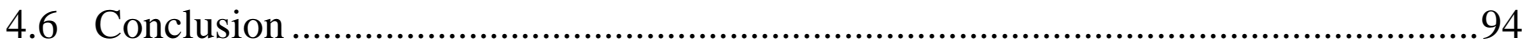

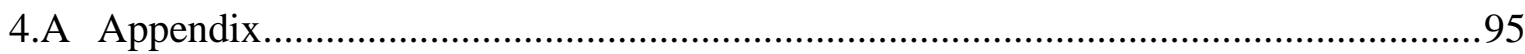

5 Customer Relationships and Financial Policy:

The Role of Customer Claims in Capital Structure Decisions

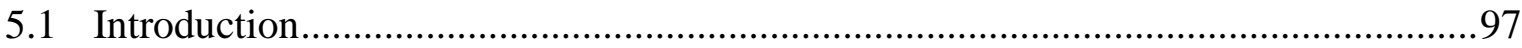

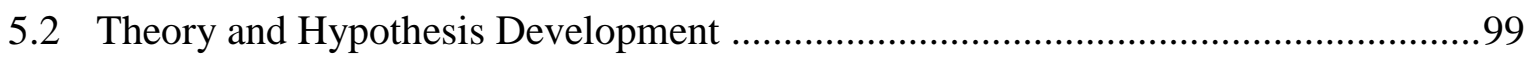

5.2.1 Stakeholder theory and capital structure decisions ....................................99

5.2.2 Measuring the commitment to customer claims ....................................... 100

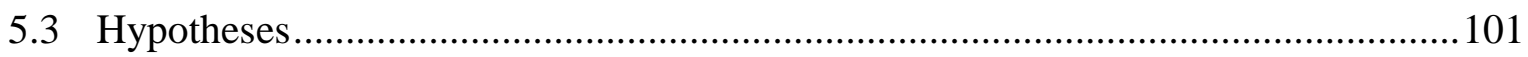

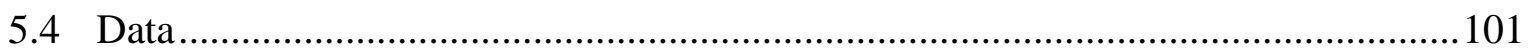

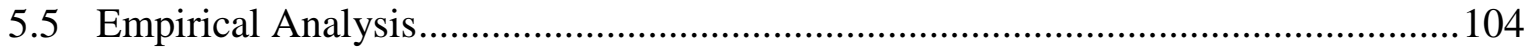

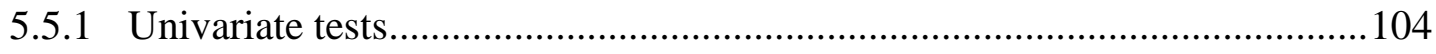

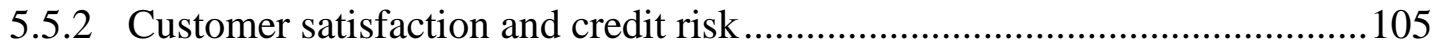

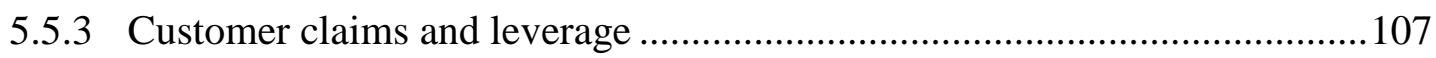

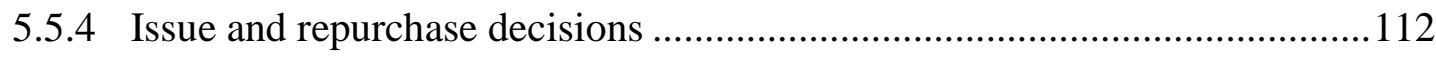

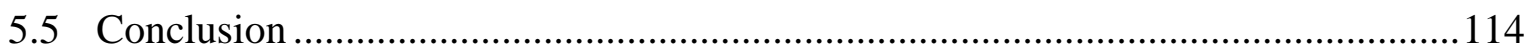

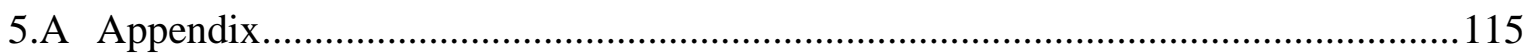

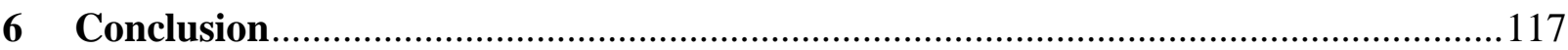

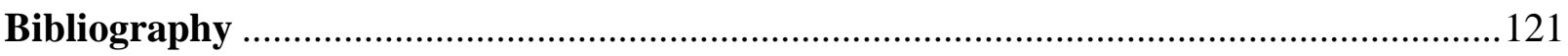

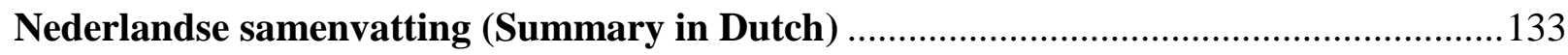

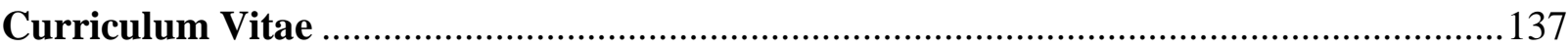




\section{List of Tables}

\section{Chapter 2}

2.1 Types of civil rights complaints (involving private suits) filed in U.S. district

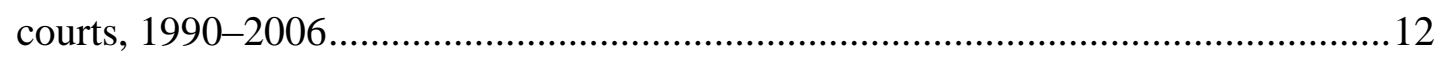

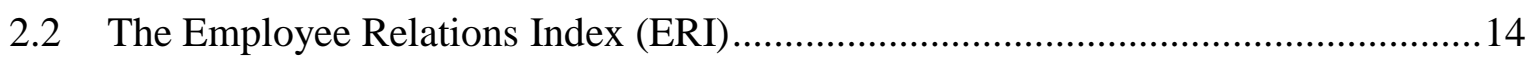

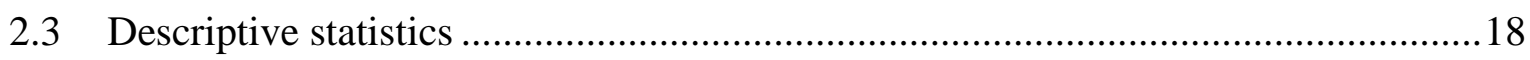

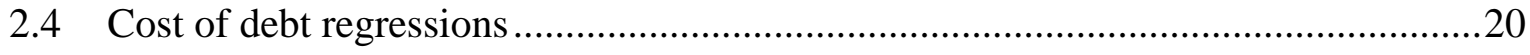

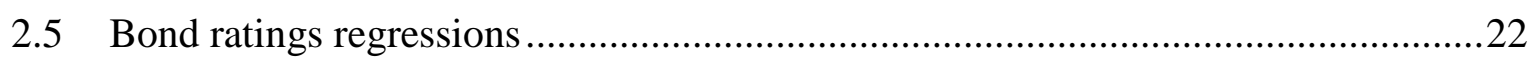

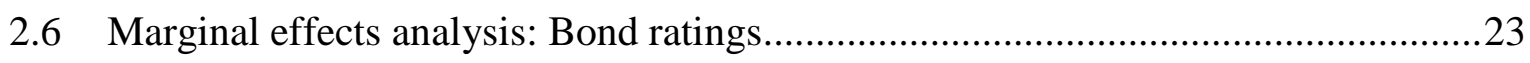

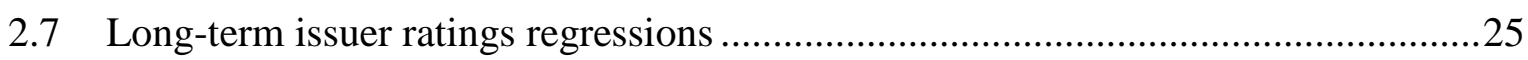

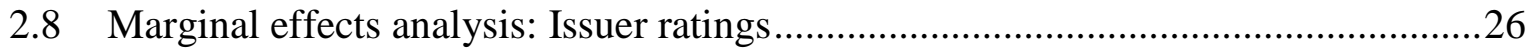

2.9 Controlling for endogeneity: Two-stage instrumental variable tests........................27

2.10 Employee relations and credit risk - Industry fixed effects .................................29

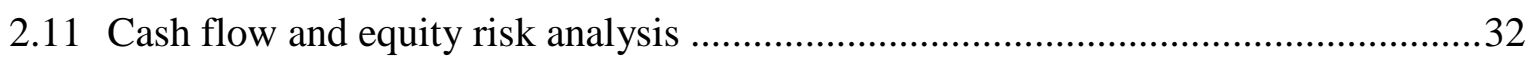

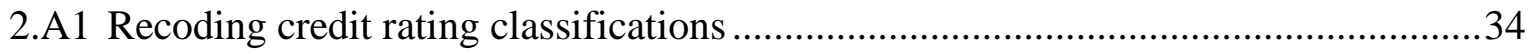

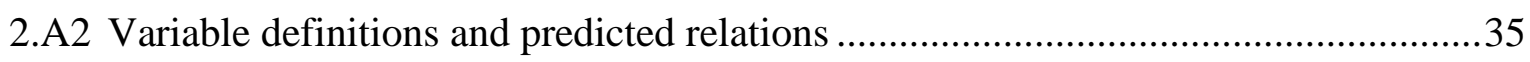

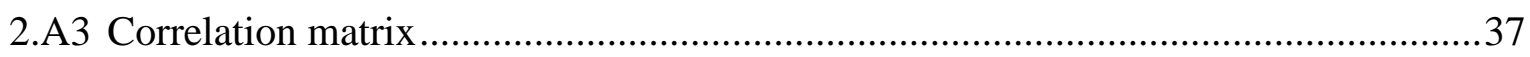

\section{Chapter 3}

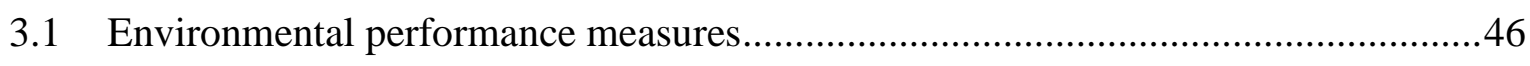

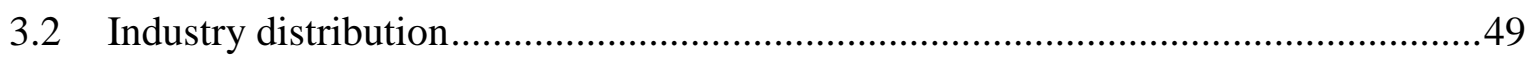

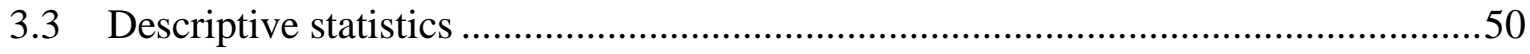

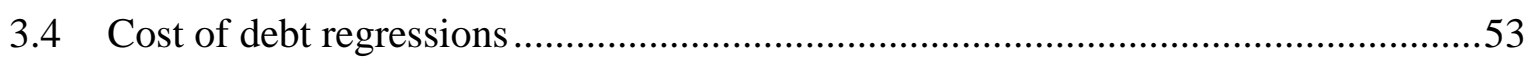

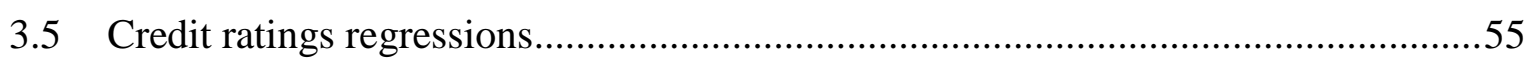

3.6 Credit risk implications of environmental performance activities............................57

3.7 Environmental performance and credit risk: High-risk industries............................58

3.8 Environmental performance and credit risk: Pulp \& allied products industry ..........60

3.9 Credit risk implications of environmental management over time...........................61

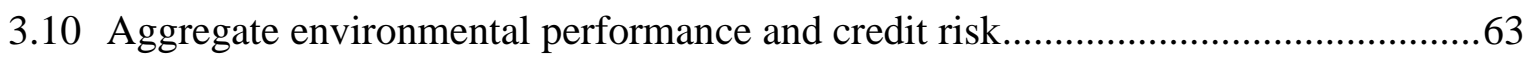

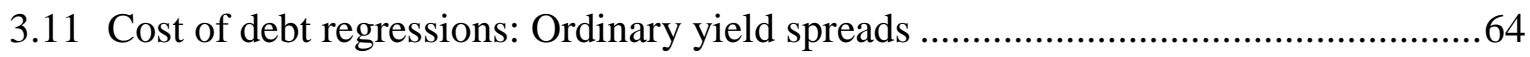

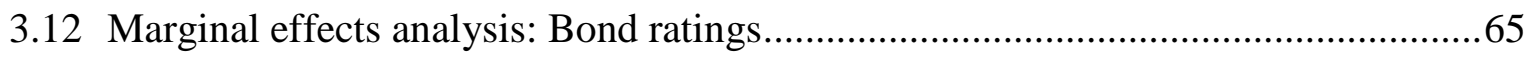

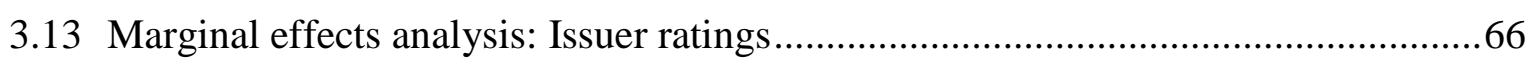

3.14 Credit risk implications of environmental performance activities (2002-2006)........68

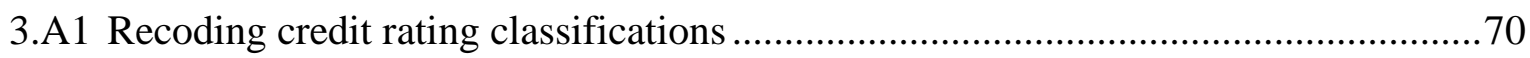




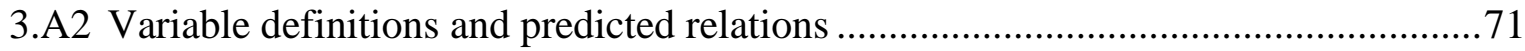

3.A3 Credit risk implications of environmental performance activities (non-orthogonalized)

\section{Chapter 4}

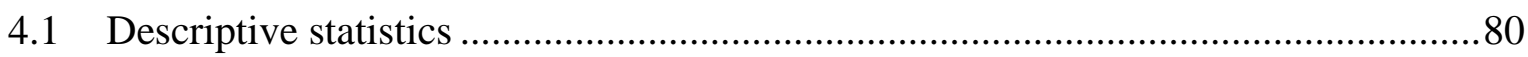

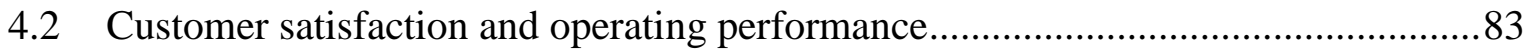

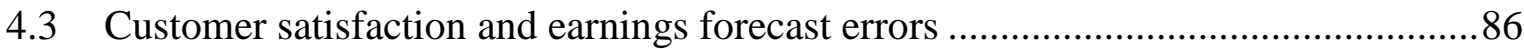

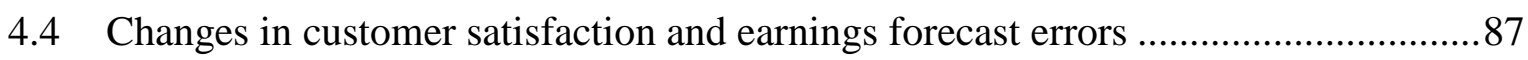

4.5 Customer satisfaction and abnormal earnings announcement returns.......................90

4.6 Changes in customer satisfaction and abnormal earnings announcement returns .....91

4.7 Levels \& changes in customer satisfaction and abnormal earnings

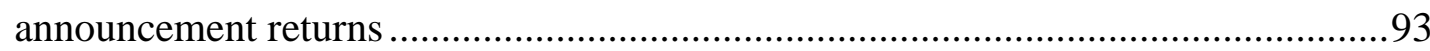

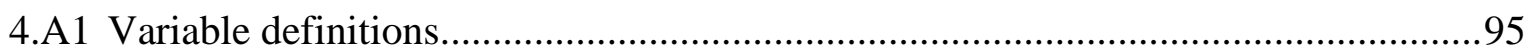

4.A2 Levels \& changes in customer satisfaction and value-weighted abnormal earnings announcement returns

\section{Chapter 5}

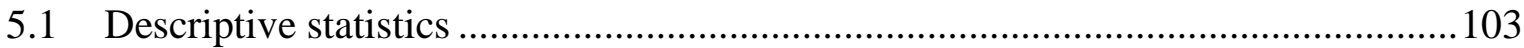

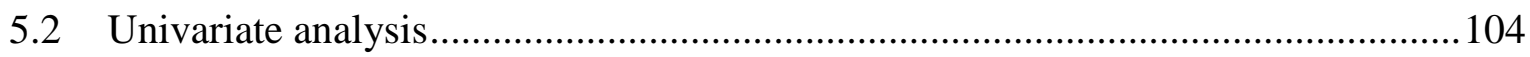

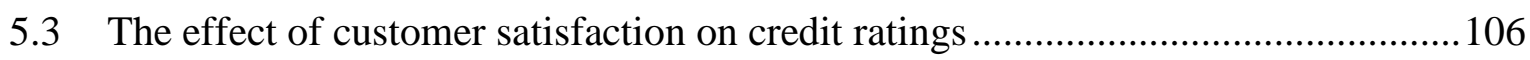

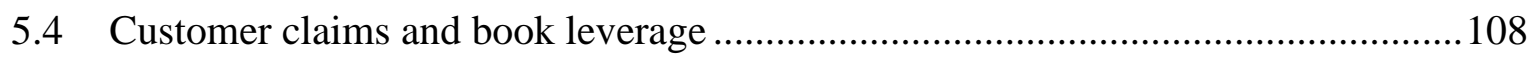

5.5 Customer claims and market leverage .............................................................. 110

5.6 Customer claims and firm leverage (excluding banks and utilities).......................111

5.7 Customer claims and issue and repurchase decisions.......................................... 113

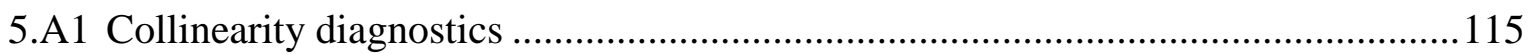

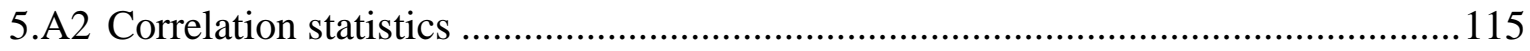




\section{Chapter 1}

\section{Introduction}

The traditional finance literature commonly assumes that stakeholders other than investors and management are of little relevance to the valuation, corporate governance, and financing of the firm. This view is primarily rooted in the prevailing theory of the firm, according to which the latter represents a nexus of contracts that balances the conflicting interests of stakeholders and protects their claims (e.g., Alchian and Demsetz, 1972; Jensen and Meckling, 1976; Klein, Crawford, and Alchian, 1978; and Fama and Jensen 1983a, 1983b). Whereas financial economists as early as Jensen and Meckling (1976) assert that this nexus of contracts comprises both the explicit and implicit claims of all stakeholders, financial theory has generally taken to focus on explicit contracts when evaluating the economic circumstances of the firm. However, when the firm is merely defined by its explicit contracts, nonfinancial stakeholders (e.g., customers, employees, suppliers) play a limited role in the main areas of finance because their claims are considered risk-free in the absence of financial distress.

Over the last decades, a stream of literature has challenged this view as being too narrow, and has instead called for a more comprehensive definition of the firm that accounts for nonfinancial stakeholder as an essential link between corporate strategy and corporate finance (e.g., Cornell and Shapiro, 1987; Zingales, 2000; Baker, Gibbons, and Murphy, 2002). The theoretical argument that is forwarded by this literature is that once the complete set of contracts is considered (i.e., the presence of risky implicit contracts is acknowledged), nonfinancial stakeholder claims become relevant in the interpretation of classic problems in finance. A growing number of empirical studies support the idea that stakeholders other than shareholders and bondholders influence the financial position and decisions of firms. For example, unions have been shown to affect the performance, value, and cost of capital of firms (Ruback and Zimmerman, 1984; Bronars and Deere, 1991; Faleye, Mehrotra, and Morck, 2006; Chen, Kacperczyk, and Ortiz-Molina, 2008a and 2008b). Other studies in turn suggest that buyers and suppliers exercise a significant influence on the financial policies of firms (e.g., Titman, 1984; Maksimovic and Titman, 1991; Kale and Shahrur, 2007; Banerjee, Dasgupta, and Kim, 2008).

This dissertation contributes to the discussion on the role of nonfinancial stakeholders in finance. Given that an exhaustive analysis of this broad topic is well beyond the scope of a single thesis, my research instead aims to fill a number of important empirical gaps in the literature. I conduct four studies on the relevance of key nonfinancial stakeholders; namely 
employees, customers, and in one case stakeholders at large. These studies can be broadly grouped into three separate themes, which I briefly introduce in the following.

\section{The Relevance of Employees for Credit Risk}

The first part of my dissertation focuses on employees, who play a central role among the stakeholders of the firm because of their function as primary input providers for the value chain. Following the transition to a global and service-driven economy, firms have become increasingly dependent on the skills and the commitment of talented employees in order to meet the growing demand for process innovation and high quality goods or services. While human capital is thus emerging as the key competitive asset for modern firms, management has experienced a continuous decline in its control over the employees that hold it. The growth in alternative employment opportunities and resulting reduction in the specificity of human capital nowadays make it easier for employees to exit the firm and withdraw their human capital (e.g., Cornell and Shapiro, 1987; Zingales, 2000). Management therefore commits considerable resources to attract, develop, and retain valuable human capital.

Central to these managerial efforts is the cultivation of employee relations, which is reflected in the employment policies and practices that a firm establishes. A growing number of studies show that the firm and its shareholders can profit from strong employee relations in the form of a reduction in employee turnover, greater productivity, higher profitability, increased firm value, and superior stock returns (e.g., Huselid, 1995; Ichniowski, Shaw, and Prennushi, 1997; Ichniowski and Shaw, 1999; Edmans, 2011). However, an important aspect that is so far not addressed in this literature is what implications human capital and the management thereof have for the credit market. On the one hand, debt investors might favor strong employee relations because of the expected improvement in the firm's financial outlook. On the other hand, the cultivation of strong employee relations entails ongoing, often considerable, and sometimes uncertain investments in human capital that may be opposed by debt investors as unwanted drains to the cash position of borrowing firms.

In Chapter 2, I study whether employee relations influence the credit risk of borrowing firms. Employee relations are expected to affect bondholder wealth through their influence on the firm's operating performance and idiosyncratic risk. Firms with sound and competitive employment practices can enhance their cash flows, while also preempting or mitigating the harmful behavior of dissatisfied employees. In contrast, poor employee relations can provoke the exit of valuable employees, limit the access to their human capital, increase both reputation and employment-related litigation risk, give rise to higher transaction costs, and thus weaken the financial outlook of the firm.

To assess the quality of employee relations, I construct an aggregate performance measure that I term the Employee Relations Index (ERI). The measure is based on the evaluation of a wide range of employment policies and practices of U.S. firms, which are covered by a specialized rating agency. In comprehensive tests of the relation between the ERI and several credit risk measures, I demonstrate that the quality of employee relations has significant implications for the credit risk of borrowing firms. 


\section{Climate Change and the Corporate Bond Market}

The second part of my dissertation takes a broader stakeholder view on finance by addressing climate change implications for the corporate bond market. The recent decades have witnessed a series of environmental disasters, in which corporate neglect caused significant damage to the natural environment, human health, and economy in the affected regions (e.g., the Seveso incident in 1976, the Exxon Valdez oil spill in 1985, the Sheng Neng 1 freighter collision with the Great Barrier Reef in 2010, and the more recent Deepwater Horizon oil spill in the Gulf of Mexico). While these incidents have triggered an ongoing controversy over a stricter regulation of corporate activities and the social responsibility of firms, it is in particular the recent climate change debate that has drawn considerable attention to the environmental impact of businesses. With public pressure on policy makers building up and calls for stricter environmental regulations growing louder, financial markets are growing wary of the potential downside risks that can arise from regulatory interventions and the generally poor understanding of the environmental risk exposure of firms.

Although the academic literature has started investigating the climate change implications for equity markets, there is comparably little research on the effect of environmental issues on the credit markets. I consider the latter as particularly surprising given that debt forms the primary means of raising long-term capital in developed markets, such as the United States. The Deepwater Horizon oil spill in the Gulf of Mexico illustrates the tremendous negative impact that environmental incidents can have for bond investors. Following BP p.l.c.'s naming as responsible party by the U.S. Government, the firm experienced a significant deterioration of its financial position. While the stock price dropped from $\$ 60.48$ to as low as $\$ 26.75$, the firm's credit default spread skyrocketed from $44 \mathrm{bps}$ up to $600 \mathrm{bps}$, and rating agencies downgraded its credit standing by several notches from AA to BBB. Bond investors who aim to protect themselves against such environmental performance related losses thus require a better understanding of how the environmental profile of firms relates to their credit risk, before making the decision to lend.

Chapter 3 analyzes whether the environmental management of firms has credit risk implications for bond investors. Environmental practices are expected to influence the solvency of borrowing firms by determining their exposure to environmental violations and the associated consequences. Firms with poor environmental practices are more likely to default on their debt obligations because of their higher exposure to potentially costly environmental litigation, reputational losses, and regulatory risk. In contrast, a proactive engagement in environmental matters can reduce both the likelihood and consequences of environmental violations, while serving as a signal that the borrowing firm is following a low-risk environmental strategy. Earlier research suggests that a proactive environmental management can also enhance the firm's financial position by reducing its costs and increasing profitability (e.g., Reinhardt, 1999; Klassen and McLaughlin, 1996; Russo and Fouts, 1997; Konar and Kohen, 2001; King and Lenox, 2002).

To assess the environmental management of borrowing firms, I construct measures for both environmental strengths and environmental concerns by using information on a wide set of their environmental activities. The respective performance information is again supplied by a specialized rating agency. Comprehensive tests of the relation between the two environmental performance measures and several credit risk proxies show that the environmental management of borrowing firms affects their credit standing significantly. My findings not only correspond with the conceptual framework that is put forward, but also suggest that the credit risk 
implications of environmental management have become more relevant over time and are not simply limited to high-risk industries.

\section{The Role of Customers in the Pricing of Stocks and Financial Policy}

The third part of this dissertation focuses on the financial relevance of customers as the primary source of income for the firm. Previous studies in the rapidly growing marketing-finance literature find that the management of customer relationships has a significant influence on the financial performance of firms. For example, customer satisfaction is reported to enhance productivity (Anderson, Fornell, and Rust, 1997), profit margins (Ittner and Larcker, 1998, Ittner, Larcker, and Taylor, 2009), return on assets as well as return on invested capital (e.g., Anderson, Fornell, and Lehmann, 1994; Anderson et al., 1997; Ittner et al., 2009), while reducing cash flow volatility (Gruca and Rego, 2005). Anderson and Mansi (2009) furthermore show that customer satisfaction is also related to higher credit ratings and a lower cost of debt.

I add to this stream of literature in two empirical studies, which follow up on theories regarding the relevance of customers in both asset pricing and corporate finance.

\section{On the mispricing of customer satisfaction}

Chapter 4 contributes to the ongoing debate on whether or not customer satisfaction is associated with abnormal stock returns. Previous studies in the marketing-finance literature suggest that stock investors do not incorporate information on customer satisfaction in their assessment of firm value (Fornell, Mithas, Morgeson III, and Krishnan, 2006; Aksoy, Cooil, Groening, Keiningham, and Yalçin, 2008). A systematic failure to account for the effect of customer satisfaction on firm performance would thus constitute a potential source of stock mispricing. The literature is still divided on the matter, since corresponding tests of short-run stock price changes (Ittner and Larcker, 1998; Fornell et al., 2006; Ittner, Larcker, and Taylor, 2009) and portfolio studies on long-run stock returns (Fornell et al., 2006; Aksoy et al., 2008; O'Sullivan, Hutchinson, and O'Connell, 2009; Jacobson and Mizik, 2009a; Ittner et al., 2009) provide mixed evidence on a mispricing of customer satisfaction by the stock market.

This study proposes complementary methods for testing whether customer satisfaction is a source of abnormal stock returns. The methods that are introduced into the discussion are extensively used in finance and accounting literatures on potential sources of stock market inefficiency (e.g., Abarbanell and Bernard, 1992; Chen, Jegadeesh, and Lakonishok, 1996; La Porta, Lakonishok, Shleifer, and Vishny, 1997; Bradshaw, Richardson, and Sloan, 2001; Skinner and Sloan, 2002; Core, Guay, and Rusticus, 2006; Edmans, 2011), and provide a more direct assessment of the hypothesis that investors fail to anticipate the effect of customer satisfaction. Should the errors in expectations hypothesis indeed hold, then I expect to find evidence that investors systematically misjudge the relation between customer satisfaction and future earnings. Moreover, investors are expected to adjust their valuations once they learn about their forecasting errors, which usually takes place around the earnings announcements of firms.

For the test of the errors in expectations hypothesis, I form portfolios based on customer satisfaction scores that are provided by the American Customer Satisfaction Index (ACSI), and submit them to the proposed methods: First, I confirm whether customer satisfaction has predictive power for the future operating performance of firms. Second, I examine whether 
customer satisfaction is associated with systematic biases in the earnings forecasts of stock market analysts. Lastly, I study whether customer satisfaction is related to stock price changes following the earnings announcements of firms. My analysis suggests that investors correctly assess the effect of customer satisfaction on the future performance of firms, and that it is thus unlikely that expectational errors are the source of abnormal stock performance.

\section{Customers and financial policy}

Chapter 5 investigates whether customers influence the financial policies of firms. Stakeholder theories argue that corporate strategy and corporate finance are inevitably intertwined, and conjecture that nonfinancial stakeholder constitute an essential link between the two (e.g., Cornell and Shapiro, 1987). While customers form an integral part of corporate strategy through marketing and their impact on financial performance, the literature remains relatively silent on whether the implementation of customer-based strategies requires the choice of a congruent financial policy. This study adds to this literature, by empirically testing a central prediction in the stakeholder theory on capital structure decisions.

The stakeholder approach predicts that firms that are committed to strong customer relationships hold relatively less debt in their capital structure than those that are not (Titman, 1984; Cornell and Shapiro, 1987; Maksimovic and Titman, 1991; Zingales 2000). The reasoning underlying this prediction is that a high debt ratio increases the likelihood that the firm defaults on the explicit and implicit claims that it issues to customers. Customers respond to this risk by adjusting their willingness to pay for the goods and services that these claims are sold together with, according to their perception of how able and willing management is to honor its promises. Firms that are committed to honoring customer claims because they expect to optimize returns or to mitigate associated downside risks, thus have an incentive to pursue a conservative capital structure so as to certify their ability and willingness to service these claims.

In order to assess whether a commitment to customer claims affects the capital structure decisions of firms, my analysis relies on the American Customer Satisfaction Index (ACSI) as a proxy for the level of such a commitment. I conjecture that the concept of customer satisfaction constitutes a suitable measure for the commitment to customer claims because it captures both, the expectations that customers have about the claims that a firm sells and their perception on how well the firm is able to meet these expectations. Using standard models from the capital structure literature, I demonstrate a significant and consistent relation between the debt leverage of firms and the proposed proxy for their commitment to customer claims. 



\title{
Chapter 2
}

\section{Employee Relations and Credit Risk*}

\begin{abstract}
This chapter studies the relevance of human capital management for bond investors. Consistent with the theory that human capital management influences organizational performance and risk, I find that employee relations explain the cross-sectional variation in credit risk. I construct an aggregate measure for the quality of employee relations based on the firm's employment practices and policies, and document that firms with stronger employee relations enjoy a statistically and economically lower cost of debt financing, higher credit ratings, and lower firmspecific risk. My findings are robust to the inclusion of a comprehensive set of controls as well as alternative explanations.
\end{abstract}

\subsection{Introduction}

In this chapter, we examine whether the credit risk of firms is affected by an important group of nonfinancial stakeholders, its employees. More specifically, we analyze how the quality with which a firm manages its human capital affects its cost of debt financing and credit ratings. Studying this association is relevant because the transition to a global and service-driven business environment has triggered a significant change in the nature of the modern firm, from the rigid and asset-intensive traditional corporation to the more flexible organizational forms that rely heavily on employees (see, e.g., Zingales, 2000). Human capital nowadays constitutes a key competitive asset that has substantial influence on organizational performance. Accordingly, managers commit considerable resources to attract, develop, and retain valuable human capital. Central to these managerial efforts is the cultivation of employee relations, which are reflected in the employment policies and practices that firms establish. But despite the fact that a growing number of studies supports the theory that strong employee relations are associated with greater productivity, higher profitability, firm value, and superior shareholder returns (e.g., Huselid, 1995; Ichniowski et al., 1997; Ichniowski and Shaw, 1999; Edmans,

\footnotetext{
* This chapter is based on Bauer, Derwall, and Hann (2011), which was presented at the 2009 American Accounting Association Meetings (New York, USA), the 2009 Academy of Management Meetings (Chicago, USA), the Labor and Human Rights Conference at Harvard Law School (Cambridge, USA), the European Centre for Corporate Engagement Conference (Maastricht, The Netherlands), and the oikos PRI Young Scholars in Finance Academy (Gais, Switzerland). I thank the Swedish foundation for strategic environmental research (MISTRA) for its financial support.
} 
2011), surprisingly little is known about how the management of human capital affects bondmarket investors.

We argue that employee relations affect bondholders through their influence on firm risk. Firms with sound and competitive employment practices can enhance their capacity to generate higher and more stable cash flows, and at the same time preempt or mitigate the harmful behavior of dissatisfied employees. In contrast, poor employee relations can limit firms' access to human capital, lead to the exit of valuable employees, increase both litigation and reputation risks, and raise transaction costs. The costs associated with such employment-related risks range from unexpected drains on the firm's cash balance to a potentially permanent impairment of its financial outlook. Although it is often implicitly assumed that firm-specific losses can be diversified away, Amato and Remolona (2003) show that investors' limited ability to fully diversify bond portfolios is likely to result in the pricing of firm specific risks in expected corporate bond returns. Consequently, we expect that the quality of employee relations is negatively related to the credit risk and hence to the firm's cost of debt financing.

To test the hypothesized relation, we construct an aggregate measure for the quality of a firm's employee relations, which we term the Employee Relations Index (ERI). We base ERI on a wide range of performance indicators for a firm's employment policies and practices that are extensively used by researchers and practitioners, in which a higher ERI score indicates relatively stronger employee relations. We assess the relevance of employee relations for bondholders by relating ERI to the cost of debt and credit ratings, based on a sample of U.S. corporate bond issues and issuer ratings.

Our analysis yields several key findings. First, we show that firms with strong employee relations enjoy a lower cost of debt financing. The relation is both economically and statistically significant: a one-point increase in ERI is associated with a decrease in the annual yield spread by 2 to 4 basis points. Second, we find that firms with strong employee relations benefit from significantly higher bond ratings. We use a broader sample of long-term issuer ratings to validate these results, and continue to find that ERI is positively associated with credit ratings.

We provide further insights into the risk implications of employee relations by using alternative risk measures. To corroborate our theory that employee relations affect bondholders through their influence on firm risk, we analyze the association between ERI and the firm's cash flow volatility (i.e., variation in ROA), systematic stock risk (i.e., CAPM beta), and idiosyncratic (i.e., firm-specific) stock volatility. Our measure of employee relations displays a negative and significant relation to idiosyncratic volatility. Since researchers such as Dai et al. (2008) believe that litigation, reputation risks, and the associated higher transaction costs positively affect firm-specific stock volatility, the results reinforce the view that these types of risk are reduced through strong employee relations.

We conduct several additional robustness tests: First, we show that the effects of union control on the cost of debt documented in Chen et al. (2008a) do not subsume the relation between ERI and credit risk. Next, we show that our results are not driven by the effects of anti-takeover provisions on the cost of debt. We control for these effects using the Gompers et al. (2003) anti-takeover index as a proxy, because earlier studies associate managerial entrenchment with the cost of debt (see, e.g., Klock et al., 2005; Cremers et al., 2007). We also address potential endogeneity biases by using two-stage least squares regressions that allow employee relations to be endogenous. 
Our study provides new insights into the determinants of credit risk by reporting that the quality of employee relations is associated with key credit risk measures on which bond investors base their decisions. Most of the earlier research that explained yield spreads and credit ratings concentrates on the relevance of conventional financial health indicators, which are largely based on accounting information (e.g., Fisher, 1959; Cohen, 1962; Horrigan, 1966; Altman, 1968; West, 1970; Kaplan and Urwitz, 1979; Lamy and Thompson, 1988; Ziebart and Reiter, 1992). However, recent work demonstrates that information about corporate governance structures, which can influence both managerial decision making and the information asymmetry between the firm and its investors, is important for the explanation of the cost of debt and credit ratings (see, e.g., Bhojraj and Sengupta, 2003; Klock et al., 2005; and Ashbaugh-Skaife et al., 2006). Given these earlier findings, there is considerable scope for research that describes associations between credit risk and the firm's relation with nonfinancial stakeholders (Bradley et al., 2008; Chen et al., 2008a and 2008b). We fill one of those gaps by studying how credit risk is affected by the management of employees, who have become a major asset in today's organizations.

A better understanding of corporate spreads not only helps to improve the risk management of defaultable securities and the liquidity of portfolios, it can also lead to more accurate pricing and an increase in the efficiency of corporate bond and derivative markets. Understanding the price that debt holders charge to borrowers is particularly important because in the United States, debt is the primary means of raising long-term capital. Although corporate bond issues in 1996 amounted to about $\$ 651$ billion while stock issues amounted to merely $\$ 122$ billion (Bhojraj and Sengupta, 2003), this gap has continuously increased over recent years: in 2006 the value of new corporate bond issues rose to about $\$ 2.59$ trillion, but according to the Federal Reserve (www.federalreserve.gov), new stock issues experienced a comparative decrease to $\$ 119$ billion. Thus, even small changes in cost of debt financing caused by differences in the management of competitive human capital, could lead to notable shifts in capital allocation.

Our study extends the findings of prior human capital studies, which have so far mainly focused on how employment practices influence productivity (e.g., Huselid, 1995; Ichniowski et al., 1997; Ichniowski and Shaw, 1999; Faleye and Trahan, 2006), employee turnover (Huselid, 1995), accounting measures of performance (Huselid, 1995), firm value (Huselid, 1995; Faleye and Trahan, 2006), and equity returns (Filbeck and Preece, 2003; Kempf and Osthoff, 2007; Edmans, 2011). To the best of our knowledge, our study is the first to provide a comprehensive assessment of the importance of employee relations for bondholder wealth.

The chapter is organized as follows. Section 2 describes how the quality of employee relations can influence firm risk, and in turn has implications for bondholder wealth. In section 3 we develop testable hypotheses for this relation. In section 4 we introduce our sample and data sources, define the variable measurements, and provide descriptive statistics. Section 5 presents our empirical models, results, and robustness tests. Section 6 concludes this chapter.

\subsection{Theory and Prior Evidence}

There is a growing consensus that firm value maximization depends on managers' relationship with multiple stakeholders, including customers, employees, suppliers, regulators, and society at large (see, e.g., Jensen and Meckling, 1976; Titman, 1984; Cornell and Shapiro, 1987; 
Boatright, 2002). Among these stakeholders, employees are particularly important because their human capital has become a key competitive asset in today's service-oriented business (Cornell and Shapiro, 1987; Pfeffer, 1996; Zingales, 2000). Firms depend on the skills and commitment of their employees to meet the global economy's growing demand for innovation, quality, speed, and adaptability. To utilize their employees as a competitive asset, managers increasingly need to rely on the quality of their employee relations as an important determinant of the decisions that employees take with respect to the firm.

Researchers such as Leat (2001) and Gennard and Hayward (2005) define employee relations as those policies and practices that aim to gain the commitment of staff and workers and to reconcile possible conflicts in the employment relationship in order to achieve organizational goals and objectives. In modern firms, such practices take into account the extent to which employees value both the monetary and the nonmonetary benefits that their employer offers them. Although conventional economic theory emphasizes the role of monetary incentive systems, the usefulness of providing both types of benefits can be justified by human relations theories (see, e.g., Maslow, 1943; Hertzberg, 1959; McGregor, 1960). These theories suggest that in societies in which the workers' basic physical needs are relatively easily satisfied, employees assign relatively more importance to nonmonetary benefits that cannot be purchased outside the firm (Edmans, 2011). Recent studies go so far as to argue that monetary incentive system can be both costly and ineffective when used in isolation (see, e.g., Akerlof and Kranton, 2005; Gibbons, 1998; Prendergast, 1999). This view is based on evidence that monetary benefits are able to "crowd out" nonmonetary incentives and thus lead to worse overall performance. ${ }^{1}$ Thus, firms now integrate more nonmonetary forms of compensation into their employment practices, such as employee involvement, health and safety programs, fair treatment policies, and job satisfaction.

There are several reasons why employee relations should matter to bondholders. First, employees can affect firm-specific risks that bondholders are vulnerable to. Whenever the quality of employee relations induces employees to take actions that either decrease the firm's ability to generate cash flows, or increase the volatility of these cash flows, it forms a source of risk for bondholders. This is generally the case if employment policies and practices do not satisfy the expectations of employees, or if management goes as far as to violate their claims (e.g., discrimination, misinformation, wrongful discharge). The main ways through which dissatisfied employees can respond to improper management practices are to limit access to their human capital, to quit, and to take legal actions against the firm.

Poor employment practices signal a management's lack of commitment to its employees and their claims, thereby negatively affecting the willingness of employees to make firmspecific investments in human capital or to permit access to it (see, e.g., Cornell and Shapiro, 1984; Rajan and Zingales, 1998; Zingales, 2000). Turnley and Feldman (1999) provide evidence that the violation of employees' expectations provokes a notable reduction in both their commitment and their loyalty to the firm, and encourages behaviors such as half-hearted effort, lateness, absenteeism, and less attention to service and product quality. The costs associated with dissatisfied employees include among others reductions in the firm's productivity, the rate of innovation, operating quality, and the ability to develop personnel who are competitive.

\footnotetext{
${ }^{1}$ For an outline of the studies that investigate the "crowding out" effect of monetary incentives see Akerlof and Kranton (2005).
} 
Turnley and Feldman (1999) also point out that employees who feel that their expectations have been ignored, report a significantly higher propensity to quit their jobs. A firm that depends heavily on its people to obtain competitive advantages is especially vulnerable to this decision, because employees who leave the firm can cause not only a competitive disadvantage, but also expropriate the firm from the significant investments that the firm had made in its workers. According to Zingales (2000), the easier access to financial capital and growing number of independent suppliers have exacerbated the problem of human capital mobility, by making it less firm-specific and thus reducing employees' dependence on one particular employer.

Next, improperly managed employee relations can result in costly litigations that create direct costs, such as damages and legal fees, and indirect costs, such as reputation loss and higher transaction costs. The U.S. Congress and federal courts have passed numerous laws that penalize exploitation and discrimination in labor markets, and employees have become more aware of their legal claims and their ability to enforce claims of improper working environments or infringement on labor rights (see, e.g., Miller and Kahn, 2003). This is particularly the case for firms with poor diversity management, which have become more prone to discrimination charges and claims for indemnity. Table 2.1 summarizes the Department of Justice Statistics, which show that employment-related complaints have accounted for about $50 \%$ of all civil rights complaints that were filed in U.S. District Courts between 1990 and 2006. ${ }^{2}$ Also the Equal Employment Opportunity Commission (EEOC), which monitors and enforces claims on discrimination, unlawful retaliation, and harassment, documents a notable increase in employment-related damages during this period. ${ }^{3}$

Even if the direct costs of employment litigation may not in themselves be the primary cause for corporate bankruptcy, such legal actions can trigger substantial reputational risks and increases in transaction costs, both of which raise the firm's probability of default. Both Karpoff and Lott (1999) as well as Bradford (2005) report that the total costs incurred by corporate defendants often significantly exceed the benefits awarded to the plaintiffs. By studying the associated drops in share prices, these authors argue that the indirect costs that corporate defendants incur in discrimination lawsuits can to a large extent be attributed to reputation loss. Moreover, Engelmann and Cornell (1988) argue that this cost-benefit difference is partially explained by the higher transaction costs that the firm incurs in establishing explicit and implicit contracts with stakeholders (see also Dai et al., 2008). Employee relations are often based on informal agreements, and the value of these agreements depends on management's reputation for fulfilling its implicit contracts (Cornell and Shapiro, 1987; Zingales, 2000). When a firm engages in questionable practices that are likely to violate the implicit claims of employees, or even becomes a defendant in a related lawsuit, then employees will assign less value to existing and future implicit contracts. Instead, they will insist that their agreements be secured in the form of explicit contracts, which will come at a higher cost to the firm. Bondholders can expect both the reputation risks and the higher transaction costs that arise from poor employment practices and litigation to disrupt a firm's regular operations, diminish its financial outlook, and consequently add to its credit risk.

\footnotetext{
${ }^{2}$ www.ojp.usdoj.gov/bjs

${ }^{3}$ www.eeoc.gov
} 
TABLE 2.1

Types of civil rights complaints (involving private suits) filed in U.S. district courts, 1990-2006 ${ }^{\mathrm{a}}$

\begin{tabular}{ccccccc}
\hline \hline Year & Total & Employment & Voting & Housing & Welfare & Other $^{b}$ \\
\hline 1990 & 18,914 & 8,272 & 140 & 367 & 135 & 10,000 \\
1991 & 19,892 & 8,370 & 247 & 452 & 130 & 10,693 \\
1992 & 24,233 & 10,771 & 494 & 527 & 125 & 12,316 \\
1993 & 27,655 & 12,962 & 213 & 590 & 114 & 13,776 \\
1994 & 32,622 & 15,965 & 224 & 730 & 122 & 15,581 \\
1995 & 36,600 & 19,059 & 208 & 735 & 116 & 16,482 \\
1996 & 42,007 & 23,152 & 229 & 932 & 83 & 17,611 \\
1997 & 43,278 & 23,796 & 141 & 854 & 91 & 18,396 \\
1998 & 42,354 & 23,735 & 108 & 838 & 66 & 17,510 \\
1999 & 41,304 & 22,490 & 102 & 1,136 & 63 & 17,513 \\
2000 & 40,908 & 21,032 & 167 & 1,284 & 80 & 18,345 \\
2001 & 37,878 & 19,371 & 173 & 1,151 & 53 & 17,130 \\
2002 & 37,391 & 19,225 & 209 & 1,231 & 61 & 16,665 \\
2003 & 37,602 & 18,768 & 139 & 1,261 & 63 & 17,371 \\
2004 & 37,374 & 18,040 & 152 & 1,169 & 54 & 17,959 \\
2005 & 33,390 & 15,344 & 143 & 821 & 48 & 17,034 \\
2006 & 30,405 & 13,042 & 122 & 593 & 49 & 16,599 \\
\hline
\end{tabular}

a. Excludes prisoner petitions from 1990-2000.

b. Specific types of civil rights cases within the "other" category cannot be distinguished.

Sources: For 1990-2000, U.S. Department of Justice, Office of Justice Programs, Civil Justice Data Brief (July 2002).

For 2001-2006, Annual Report of the Director. Washington, D.C.: Administrative Office of the U.S. Courts (table C-2).

\subsection{Hypotheses}

The main theory underlying our hypotheses is that the quality of employee relations affects bondholders through its influence on firm-specific risks. We expect to find that sound employment practices and policies enhance the level and stability of expected cash flows, and also mitigate the risks associated with the harmful behavior of dissatisfied employees.

Although earlier studies often implicitly assume that bond investors, like equity investors, can diversify their corporate portfolios against firm-specific losses, Amato and Remolona (2003) show that the high negative skewness in bond returns makes efficient diversification difficult. Bondholders have a limited upside potential and considerably larger downside potential from exposure to firm-specific events, which means that to achieve full diversification they would be required to invest in a very large number of different bonds. Since bond portfolios of this magnitude are rarely observed, the expected return on corporate bonds is likely to reflect firm-specific default risk. Consequently, bondholders should be sensitive to the risk that a borrower's policies and practices may pose to the recovery of their loan and interest, 
particularly if these practices pertain to competitive assets. We derive the following hypotheses, stated in alternative form:

Hypothesis 1: Firms with stronger employee relations have a lower cost of debt.

Hypothesis 2: Firms with stronger employee relations have higher credit ratings.

\subsection{Data}

\subsubsection{Employee relations}

We measure the quality of a firm's employee relations by using data from Kinder, Lydenberg and Domini Research \& Analytics (KLD). KLD is an independent investment research provider that specializes in the analysis of firms' employment practices, community involvement, corporate governance, product quality, environmental performance, adherence to human rights standards. One of the advantages of using KLD is that it avoids potential conflicts of interest by not consulting with the firms that it researches. It evaluates a large cross-section of firms by systematically collecting information from, e.g., surveys among firms' investor relations officers, government agencies, nongovernmental organizations, over 14,000 global media publications, financial reports, regulatory filings (e.g., 10-Ks), corporate websites, external surveys and ratings, and academic studies. The resulting KLD STATS database contains performance information on all Standard \& Poor (S\&P) 500 constituents as of 1991, the 1,000 largest publicly traded U.S. companies from 2001 to 2002, and the 3,000 largest publicly traded U.S. companies thereafter.

To achieve a cross-sectional ranking of the quality of employee relations, we focus on performance indicators of the two KLD dimensions that relate to the management of human capital, Diversity Management and Employee Relations. These two categories cover the strengths and concerns that each firm in the database displays for the employment policies and practices listed in Table 2.2.

The indicators correspond with monetary and nonmonetary employment practices and policies that previous studies have identified as determinants of organizational performance and firm value (see, e.g., Huselid, 1995; Ichnioswki et al., 1997; Ichniowski and Shaw, 1999; Faleye and Trahan, 2006), or that have been central to numerous legal complaints (www.eeoc.gov). KLD assigns a value of zero or one to each of the indicators. These values denote the absence and presence of a strength or concern, respectively. The individual indicators are summed to obtain the total number of strengths and the total number of concerns.

To develop a measure for employee relations that integrates all strengths and concerns, we follow previous studies that use KLD. It is common practice to aggregate the individual items by adding all strengths and subtracting all weaknesses in a given year; see, e.g., Graves and Waddock (1994); Waddock and Graves (1997); Johnson and Greening (1999); Kane et al. (2005); Fisman et al. (2006); Kempf and Osthoff (2007); and Statman and Glushkov (2009). The score that we obtain for each firm represents our measure for the quality of employee relations, the Employee Relations Index (ERI). 
TABLE 2.2

\section{The Employee Relations Index (ERI)}

This table lists the employment related performance indicators that we use to construct our measure of a firm's employee relations quality. We collect information on these qualitative indicators from the Employee Relations and Diversity dimensions of KLD's STATS database. Panel A lists the performance strength indicators for both dimensions. Panel B reports their performance concern indicators. If a firm displays a respective strength or concern, KLD assigns a value of zero or one to the corresponding indicator, where zero denotes "no concern/strength" and one denotes a "concern/strength". The employee relations index (ERI) equals the difference between the total number of strengths and the total number of concerns. Source: www.kld.com.

\section{PANEL A: Performance strength indicators}

$\begin{array}{ll}\text { CEO } & \begin{array}{l}\text { The company's chief executive officer is a woman or a member of a minority } \\ \text { group. }\end{array}\end{array}$

Promotion

\section{Board of Directors}

Work/Life Benefits

Women \& Minority Contracting

Employment of Disabled

Gay \& Lesbian Policies

Other Diversity Management Strengths

Union Relations

Cash Profit Sharing

Employee Involvement

Retirement Benefits Strength

Health and Safety Strength

Other Strength
The company has made notable progress in the promotion of women and minorities, particularly to line positions with profit-and-loss responsibilities in the corporation.

Women, minorities, and/or the disabled hold four seats or more (with no double counting) on the board of directors, or one third or more of the board seats if the board numbers less than 12 .

The company has outstanding employee benefits or other programs addressing work/life concerns, e.g., childcare, elder care, or flextime.

The company does at least $5 \%$ of its subcontracting, or otherwise has a demonstrably strong record on purchasing or contracting, with women and/or minority-owned businesses.

The company has implemented innovative hiring programs; other innovative human resource programs for the disabled, or otherwise has a superior reputation as an employer of the disabled.

The company has implemented notably progressive policies towards its gay and lesbian employees. In particular, it provides benefits to the domestic partners of its employees.

The company has made a notable commitment to diversity that is not covered by other KLD ratings.

The company has taken exceptional steps to treat its unionized workforce fairly.

The company has a cash profit-sharing program through which it has recently made distributions to a majority of its workforce.

The company strongly encourages worker involvement and/or ownership through stock options available to a majority of its employees; gain sharing, stock ownership, sharing of financial information, or participation in management decision-making.

The company has a notably strong retirement benefits program.

The company has strong health and safety programs.

The company has strong employee relations initiatives not covered by other KLD ratings. 
TABLE 2.2 (continued)

The Employee Relations Index (ERI)

\begin{tabular}{ll}
\hline PANEL B: Performance concern indicators \\
\hline Diversity Management Controversies & $\begin{array}{l}\text { The company has either paid substantial fines or civil penalties as a result of } \\
\text { affirmative action controversies, or has otherwise been involved in major } \\
\text { controversies related to affirmative action issues. } \\
\text { The company has no women on its board of directors or among its senior line } \\
\text { managers. }\end{array}$ \\
Other Diversity Management Concerns & $\begin{array}{l}\text { The company is involved in diversity controversies not covered by other KLD } \\
\text { ratings. }\end{array}$ \\
Tnion Relations & $\begin{array}{l}\text { The company has a history of notably poor union relations. } \\
\text { The company has made significant reductions in its workforce in recent years. }\end{array}$ \\
Retirement Benefits Concern & $\begin{array}{l}\text { The company has either a substantially underfunded defined benefit pension } \\
\text { plan, or an inadequate retirement benefits program. }\end{array}$ \\
Health and Safety Concern & $\begin{array}{l}\text { The company recently has either paid substantial fines or civil penalties for } \\
\text { willful violations of employee health and safety standards, or has been otherwise } \\
\text { involved in major health and safety controversies. } \\
\text { The company is involved in an employee relations controversy that is not } \\
\text { covered by other KLD ratings. }\end{array}$ \\
\hline
\end{tabular}

\subsubsection{Credit risk measures}

We collect yield spreads and bond ratings from the Mergent Fixed Income Securities Database (FISD). FISD provides information on more than 140,000 publicly offered U.S. bonds that were issued between 1950 and 2006, including details on more than 550 bond characteristics. To limit any confounding effects that might result from bond issue-specific characteristics, we restrict our analysis to unsecured senior and senior-subordinated corporate debt. We also exclude bonds with option components or other nonstandard features (i.e., callable, puttable, convertible, exchangeable, preferred, perpetual, asset-backed, private placements, part of unit deals, sinking fund provisions). After matching our credit risk measures with the ERI and control variables, our sample comprises 2,265 bonds issued by 568 firms during the period from 1995 to 2006. FISD reports market quoted yield spreads for 2,141 of these bond issues, and compiles bond ratings for each bond in the sample.

The first dependent variable is the firm's cost of debt financing, Spread, which we define as the market quoted yield spread of a new debt issue (see, e.g., Bhojraj and Sengupta, 2003). The yield spread equals the difference between a bond issue's offering yield to maturity and the yield to maturity of its corresponding treasury benchmark. Therefore, the spread reflects the premium that the market requires for assuming the risk that a borrowing firm will not be able to honor its debt obligations. Since the distribution of the corporate yield spreads exhibits positive skewness, we study yield spreads after lognormal transformation, $\ln ($ Spread).

Our second dependent variable is the bond specific credit rating, Bond Rating. We take an equally weighted average of S\&P and Moody's ratings to construct our bond ratings variable. If only a single bond rating from either rating agency is available, then this rating receives the full 
weight. ${ }^{4}$ For a bond rating to be included in our sample, we require that the bond issue's offering date and its rating date are at most 90 days apart. We recode the multiple rating classifications into numerical values by using a seven-point scale that ranges from $\mathrm{CCC}^{+}-\mathrm{D}$ (lowest ratings) to AAA (highest rating), following Ashbaugh-Skaife et al. (2006). A detailed overview of the rating schedule that we use to recode the credit ratings is presented in Panel A of Table 2.A1 in the appendix.

As a third dependent variable we use the S\&P long-term issuer ratings, Issuer Rating, which we collect from Compustat. The data cover 1,070 firms over the same sample period, and comprise 5,568 issuer ratings that we convert into a numerical ranking according to the conversion scheme used for the bond ratings.

\subsubsection{Control variables}

Our investigation includes two comprehensive sets of control variables that account for the role of bond issuer specific and bond issue specific characteristics as cross-sectional determinants of credit risk (see, e.g., Ashbaugh-Skaife et al., 2006; Bradley et al., 2007; Bhojraj and Sengupta, 2003; Cremers et al., 2007). Table 2.A2 in the appendix provides variable definitions and their predicted relation with the dependent variables.

The first set of controls comprises characteristics that are specific to the bond issuer which we obtain from Compustat. Leverage is the firm's financial leverage, defined as the ratio of its total liabilities to total assets. Size measures firm size, and is defined as the natural logarithm of its total assets. Capital Intensity is the ratio of fixed assets to total assets. Interest Coverage is the interest coverage ratio, defined as operating income before depreciation divided by interest expense. ROA is the accounting return on assets, defined as the ratio of income before extraordinary items to total assets. Loss is a dummy variable that equals one if a firm's net income before extraordinary items is negative in the current and prior fiscal year. Financial and Utility are dummy variables that equal one if a firm operates in the financial or utility sector. We control for firms operating in these regulated industries because they have traditionally experienced less default risk than firms operating in nonregulated industries.

The second set of controls comprises characteristics that are specific to the bond issue. The data are compiled by Mergent FISD and accompany the sampled bond issues. TTM is a bond's time-to-maturity stated in years, and is positively associated with a debt issue's risk. Issue Size is the size of a bond issue, defined as the natural logarithm of its initially offered par value. The relation between the debt amount issued and credit risk is ambiguous. Larger debt issues are generally associated with higher liquidity, and therefore with a lower yield spread. However, a large debt issue also implies a higher probability of default for the issuer and a higher expected absolute loss for the bondholder. Subordinate is a dummy variable that equals one if the bond issue is denoted senior-subordinated. Speculative is a dummy variable that is equal to one if the bond issue is below investment grade according to $\mathrm{S} \& \mathrm{P}\left(\mathrm{BBB}^{-}\right)$or Moody's (Baa3). A downgrading to speculative grade is generally accompanied by a considerable increase in the cost of debt financing, resulting from the lower credit status and reduced liquidity of the firm's debt securities.

\footnotetext{
${ }^{4}$ Results of regressions that are based on separate S\&P or Moody's ratings are similar to those reported in this chapter and are available on request.
} 
We also account for two variables that have been linked to the dependent variables. Union is our proxy for the ability of unions to influence corporate decisions in the interest of employees. Unions play a central role in voicing employee interests and in the formulation of employment contracts. They have been shown to influence firm performance, firm value (see, e.g., Ruback and Zimmerman, 1984; Bronars and Deere, 1991; Faleye, Mehrotra, and Morck, 2006), and the cost of capital (Chen et al. 2008a, 2008b). We obtain information on union control from the Union Membership and Coverage Database (Hirsch and MacPherson, 2003), which defines it as the percentage of workers in a firm's census industry classification (CIC) industry, ${ }^{5}$ who are covered by unions in their collective bargaining (see, e.g., Connolly et al., 1986; Bronars and Deere, 1991). Hirsch and Macpherson (2003) compile the data from the Current Population Survey (CPS), which is conducted by the U.S. Census Bureau and the U.S. Bureau of Labor Statistics. Matching Union with our samples reduces the bond issue data to 1,793 yield spreads and 1,895 bond ratings. We note that we exclude 61 firms for which we can make no clear allocation to a census industry classification, for example, because their operations are diversified across different industry segments.

Gindex, is the governance index of anti-takeover provisions introduced by Gompers, Ishii, and Metrick (2003), and serves as our proxy for the rights that shareholders hold within the corporate governance structure of a firm. The Gindex ranges from one to 24, where one denotes the strongest shareholder rights. Recent governance studies (e.g., Bhojraj and Sengupta 2003; Ashbaugh-Skaife et al. 2006) document that the cross-sectional variation in the credit risk of firms is partially explained by their corporate governance structure. Takeover defenses and their impact on the agency cost of debt have received considerable attention in studies such as those by Klock et al. (2005), Cremers et al. (2007) and Chava et al. (2008). Taken as a whole, these studies suggest that creditors favor protection from market control because such protection limits the risk of costly takeovers or corporate restructuring. Because information on the Gindex is only available for 1995, 1998, 2000, 2002, 2004, and 2006, including this control reduces the samples to respectively, 790 yield spreads, 823 bond ratings, and 2,421 issuer ratings. We note that we follow a conservative approach and do not fill the missing years by interpolating information on the Gindex.

\subsubsection{Descriptive statistics}

Table 2.3 provides summary statistics on the regression variables that are used in our analysis of credit risk. For ease of interpretation, we report the variables $\ln ($ Spread), Size, and Issue Size in real values instead of their logarithms. To control that our results are not affected by outliers, we winsorize all continuous variables at the first and $99^{\text {th }}$ percentile.

The employee relations index has a median score of one, and a sample variation that ranges from -4 to eight, and is evenly distributed (see Figure 2.A1 in the Appendix). The statistics on bond issue characteristics confirm that our tests are based on an economically meaningful and representative sample. The median Spread is 120 basis points, and the mean is 149 basis points. Spread exhibits considerable variation, with a sample range of $9.42 \%$ and standard deviation of 104 basis points. The median Bond Rating equals $\mathrm{BBB}^{+}$, which corresponds with the reported median issue yield spread and a median maturity of ten years. The median bond issue size equals $\$ 300$ million. Of the 2,265 bond issues, only $2 \%$ are denoted senior- subordinated debt

\footnotetext{
${ }^{5}$ See www.unionstats.com for a conversion of the CIC codes into SIC or NAICS codes.
} 
TABLE 2.3

\section{Descriptive statistics}

This table provides summary statistics of the regression variables used in our yield spread and credit rating analyses for the 1995-2006 period. We note that we report log-transformed variables (i.e., Spread, Size, Issue Size) in real values for ease of interpretation. ERI is the employee relations index. Spread is the issue yield spread expressed in basis points, defined as the natural logarithm of the difference between an issue's offering yield and the yield of its benchmark treasury issue. Bond Rating is the issue-specific credit rating, defined as the average of $\mathrm{S} \& \mathrm{P}$ and Moody's issued ratings. We define Issuer Rating as the S\&P long-term domestic issuer rating, Leverage as the ratio of total liabilities to total assets, Size as the natural logarithm of total assets, Capital Intensity as the ratio of fixed assets to total assets, and Interest Coverage as operating income before depreciation divided by interest expense. ROA is the ratio of income before extraordinary items to total assets. Loss is a dummy variable that equals one if a firm's net income before extraordinary items is negative in the current and prior fiscal year and zero otherwise. Financial and Utility are dummy variables that equal one if a firm operates in the financial or utility sector, respectively, and zero otherwise. TTM is the issue's time to maturity stated in years. Issue Size is the size of a bond issue, defined as the natural logarithm of its initially offered par value. Subordinate is a dummy variable that equals 1 if the bond issue is denoted senior-subordinated. Speculative is a dummy variable that is equal to one if the issued debt is of speculative grade and zero otherwise. We define Union as the percentage of workers in the firm's CIC industry that are covered by unions in their collective bargaining. Gindex is a governance index that measures shareholder rights/takeover defenses, which is available for the years 1995, 1998, 2000, 2002, 2004, and 2006. We winsorize all continuous variables at the $1^{\text {st }}$ and $99^{\text {th }}$ percentile to control for outliers.

\begin{tabular}{|c|c|c|c|c|c|c|}
\hline Variable & \# Obs. & Mean & Std. Dev. & Median & Min. & Max. \\
\hline \multicolumn{7}{|l|}{ Employee Relations Index } \\
\hline ERI & 2,265 & 0.94 & 1.85 & 1 & -4 & 8 \\
\hline \multicolumn{7}{|l|}{ Credit Risk Measures } \\
\hline Spread (in bps) & 2,141 & 149.25 & 104.31 & 120 & 3 & 945 \\
\hline Bond Rating & 2,265 & 4.40 & 0.96 & 4 & 1 & 7 \\
\hline Issuer Rating & 5,568 & 3.69 & 1.17 & 4 & 1 & 7 \\
\hline \multicolumn{7}{|l|}{ Issuer Specific Controls } \\
\hline Leverage (in \%) & 2,265 & 69.35 & 15.12 & 68.38 & 36.08 & 123.09 \\
\hline Size (in $\mathrm{BM} \$$ ) & 2,265 & 39.09 & 93.17 & 12.92 & 0.28 & 979.41 \\
\hline Capital Intensity (in \%) & 2,265 & 57.83 & 40.21 & 54.20 & 0.06 & 174.85 \\
\hline Interest Coverage & 2,265 & 9.16 & 8.94 & 6.44 & -1.51 & 45.96 \\
\hline ROA (in \%) & 2,265 & 4.23 & 4.58 & 3.74 & -21.73 & 15.76 \\
\hline Loss & 2,265 & 0.03 & 0.18 & 0 & 0 & 1 \\
\hline Financial & 2,265 & 0.14 & 0.35 & 0 & 0 & 1 \\
\hline Utility & 2,265 & 0.08 & 0.28 & 0 & 0 & 1 \\
\hline \multicolumn{7}{|l|}{ Issue Specific Controls } \\
\hline Subordinated & 2,265 & 0.02 & 0.15 & 0 & 0 & 1 \\
\hline TTM (in years) & 2,265 & 12.48 & 11.82 & 10 & 0.25 & 100 \\
\hline Issue Size (in MM\$) & 2,265 & 439.69 & 398.12 & 300 & 10 & 2,500 \\
\hline Speculative & 2,265 & 0.13 & 0.34 & 0 & 0 & 1 \\
\hline \multicolumn{7}{|l|}{ Additional Controls } \\
\hline Union (in \%) & 1,895 & 15.98 & 16.22 & 10.20 & 0 & 75.3 \\
\hline Gindex & 823 & 9.92 & 2.43 & 10 & 3 & 17 \\
\hline
\end{tabular}


and $13 \%$ fall into the speculative grade category. The spread and rating statistics are consistent with the observation that most issues in the sample are senior and investment grade issues. The median size of the debt issuing firms is around $\$ 13$ billion but there is large variation in issue size.

Table 2.A3 in the Appendix reports pairwise Pearson product-moment correlations (lower left of matrix) and Spearman rank-order correlations (upper right of matrix) for the regression variables. We include the rank-order correlations for the interpretation of the ordinal variables, Bond Rating, ERI, and the Gindex. An inspection of the correlations indicates that multicollinearity is not a real concern, which is confirmed by additional (unreported) variance inflation factors (VIF) tests, which show that the VIFs are all well below the usual critical value of four. A VIF of four implies that the standard error of the corresponding regression coefficient is doubled due to multicollinearity.

The correlation statistics provide a first indication that the quality of employee relations is negatively related to credit risk, before controlling for the effects of any other variables. ERI is negatively correlated with $\ln$ (Spread) $(\rho=-0.22)$ and positively correlated with Bond Rating $(\rho=0.34)$. Also, firms with better employee relations tend to be larger in size $(\rho=0.34)$, enjoy a higher profitability $(\rho=0.12)$, and interest coverage $(\rho=0.18)$. Furthermore, the correlation between $E R I$ and union control is negative $(\rho=-0.15)$, suggesting that the influence of unions on corporate strategy is negatively associated with firms' investments in employee relations.

\subsection{Empirical Analysis}

\subsubsection{Employee relations and the costs of debt}

In our first test, we regress the firm's cost of debt on our measure of the quality of employee relations and control variables. The general model for the cost of debt takes the form:

$$
\ln \left(\text { Spread }_{i, t}=\alpha+\beta \text { ERI }_{i, t}+\sum_{k=1}^{K} \gamma_{k} \text { Issuer }_{k, i, t}+\sum_{j=1}^{J} \delta_{j} \text { Issue }_{j, i, t}+\varepsilon_{i, t}\right.
$$

where $\ln ($ Spread $)$ is the natural logarithm of the bond issue's yield spread, and ERI denotes the firm's employee relations index. Issuer and Issue refer to the respective sets of characteristics that serve as control variables in the regressions.

We run pooled OLS tests with fixed time effects to estimate model (1), and test the significance of its coefficients using standard errors that are robust to heteroskedasticity and conservatively clustered at the firm level. Not correcting standard errors for correlation within clusters can lead to exaggerated $t$-statistics (Petersen, 2008). Table 2.4 reports the multivariate regression results for the cost of debt. Our confidence in the model's fit is reinforced by the adjusted $\mathrm{R}^{2} \mathrm{~s}$, which are 0.62 to 0.66 . The coefficients of the control variables are in general statistically significant under all model specifications, and carry signs that are consistent with previous studies. The only exceptions are the Financial and Utility variable, whose coefficients do not show their predicted signs, yet are not statistically significant. ${ }^{6}$

\footnotetext{
${ }^{6}$ We note that regressions based on a sample that excludes bond issues from financial firms and utilities does not affect the conclusions of this study. These results are available from the authors on request.
} 


\section{TABLE 2.4}

\section{Cost of debt regressions}

This table reports on pooled OLS tests of the log-transformed yield spread ( $\ln ($ Spread $)$ ) on the employee relations index $(E R I)$, an array of issuer and issue specific control variables, and year effects. We extend the general model to account for the level of union control (Union) and the governance structure of the firm (Gindex). To ensure that the reduction in sample size caused by the inclusion of Gindex does not drive the results, we regress $\ln (\operatorname{Spread})$ on the employee relations index using the limited sample (model (1c)), before including Gindex in model (1d).

\begin{tabular}{|c|c|c|c|c|}
\hline & (1a) & (1b) & (1c) & (1d) \\
\hline ERI & $\begin{array}{l}-0.0165 * * * \\
(-2.30)\end{array}$ & $\begin{array}{l}-0.0182 * * \\
(-2.25)\end{array}$ & $\begin{array}{l}-0.0318^{* * * *} \\
(-3.03)\end{array}$ & $\begin{array}{l}-0.0322 * * * \\
(-3.07)\end{array}$ \\
\hline Union & & $\begin{array}{l}0.0001 \\
(0.09)\end{array}$ & $\begin{array}{l}-0.0014 \\
(-1.40)\end{array}$ & $\begin{array}{l}-0.0014 \\
(-1.46)\end{array}$ \\
\hline Gindex & & & & $\begin{array}{l}0.0075 \\
(1.10)\end{array}$ \\
\hline Leverage & $\begin{array}{l}0.0020^{*} \\
(1.91)\end{array}$ & $\begin{array}{l}0.0022 * * \\
(2.10)\end{array}$ & $\begin{array}{l}0.0011 \\
(1.00)\end{array}$ & $\begin{array}{l}0.0007 \\
(0.53)\end{array}$ \\
\hline Size & $\begin{array}{l}-0.1321 * * * \\
(-10.38)\end{array}$ & $\begin{array}{l}-0.1263 * * * \\
(-9.45)\end{array}$ & $\begin{array}{l}-0.1311 \text { *** } \\
(-8.83)\end{array}$ & $\begin{array}{l}-0.1151 * * * \\
(-6.59)\end{array}$ \\
\hline Capital Intensity & $\begin{array}{l}-0.0009 * * * \\
(-2.67)\end{array}$ & $\begin{array}{l}-0.0009 * * \\
(-2.56)\end{array}$ & $\begin{array}{l}-0.0010^{* *} \\
(-2.20)\end{array}$ & $\begin{array}{l}-0.0006 \\
(-1.23)\end{array}$ \\
\hline Interest Coverage & $\begin{array}{l}-0.0083 * * * \\
(-4.44)\end{array}$ & $\begin{array}{l}-0.0075 * * * \\
(-4.02)\end{array}$ & $\begin{array}{l}-0.0072 * * * \\
(-3.73)\end{array}$ & $\begin{array}{l}-0.0086 * * * \\
(-4.33)\end{array}$ \\
\hline ROA & $\begin{array}{l}-0.0278 * * * \\
(-8.45)\end{array}$ & $\begin{array}{l}-0.0274 * * * \\
(-8.51)\end{array}$ & $\begin{array}{l}-0.0289 * * * \\
(-8.23)\end{array}$ & $\begin{array}{l}-0.0265 * * * \\
(-5.69)\end{array}$ \\
\hline Loss & $\begin{array}{l}0.1573 * * \\
(2.18)\end{array}$ & $\begin{array}{l}0.1604 * * \\
(2.17)\end{array}$ & $\begin{array}{l}0.1940 * * \\
(2.47)\end{array}$ & $\begin{array}{l}0.2315^{* *} \\
(2.13)\end{array}$ \\
\hline Subordinated & $\begin{array}{l}0.1721 \text { *** } \\
(2.68)\end{array}$ & $\begin{array}{l}0.1789 \text { *** } \\
(2.82)\end{array}$ & $\begin{array}{l}0.2260^{* * *} \\
(3.11)\end{array}$ & $\begin{array}{l}0.2149 \text { *** } \\
(3.29)\end{array}$ \\
\hline TTM & $\begin{array}{l}0.0100^{* * * *} \\
(11.11)\end{array}$ & $\begin{array}{l}0.0100 * * * \\
(11.02)\end{array}$ & $\begin{array}{l}0.0112^{* * * *} \\
(10.12)\end{array}$ & $\begin{array}{l}0.0121 \text { *** } \\
(7.71)\end{array}$ \\
\hline Issue size & $\begin{array}{l}0.0273 \\
(1.18)\end{array}$ & $\begin{array}{l}0.0306 \\
(1.35)\end{array}$ & $\begin{array}{l}0.0364 \\
(1.42)\end{array}$ & $\begin{array}{l}-0.0108 \\
(-0.27)\end{array}$ \\
\hline Speculative & $\begin{array}{l}0.6761 \text { *** } \\
(20.31)\end{array}$ & $\begin{array}{l}0.6719 \text { *** } \\
(20.40)\end{array}$ & $\begin{array}{l}0.6922 * * * \\
(19.12)\end{array}$ & $\begin{array}{l}0.6162 * * * \\
(12.76)\end{array}$ \\
\hline Financial & $\begin{array}{l}0.0698 \\
(1.52)\end{array}$ & $\begin{array}{l}0.0618 \\
(1.33)\end{array}$ & $\begin{array}{l}0.0824 \\
(1.60)\end{array}$ & $\begin{array}{l}0.0588 \\
(1.05)\end{array}$ \\
\hline Utility & $\begin{array}{l}0.0451 \\
(1.16)\end{array}$ & $\begin{array}{l}0.0471 \\
(1.20)\end{array}$ & $\begin{array}{l}0.0559 \\
(1.35)\end{array}$ & $\begin{array}{l}0.0578 \\
(0.94)\end{array}$ \\
\hline Adjusted $\mathrm{R}^{2}$ & 0.66 & 0.65 & 0.62 & 0.62 \\
\hline \# Observations & 2,141 & 1.793 & 790 & 790 \\
\hline
\end{tabular}

$* * * \mathrm{p}<0.01, * * \mathrm{p}<0.05, * \mathrm{p}<0.1$

Robust t-statistics in parentheses

Standard errors are heteroskedasticity robust and clustered at the firm 
The results consistently support our hypothesis that firms with better employee relations enjoy a lower cost of debt. We find that our general model (1a) reports a negative and statistically significant loading on ERI, even after controlling for the effects of issuer and issue specific determinants of corporate bond spreads. Furthermore, this effect is independent from any union effect documented in prior studies (Chen et al., 2008a). Model (1b) shows that the ERI coefficient continues to be negative and statistically significant in the presence of the Union control variable. Since an extension of the model using the Gindex substantially reduces the number of observations, we re-estimate model (1b) using the reduced sample in (1c), before augmenting this model with the Gindex in (1d). The purpose of this re-estimation is to ensure that the factor loadings reported in model (1d) are not affected by sample bias. A comparison of models (1c) and (1d) confirms that firms with stronger employee relations enjoy a lower spread, independent of the corporate governance index.

To assess the economic significance of employee relations, we estimate how much a firm would enjoy a decrease in the cost of debt resulting from a unit increase in ERI. The estimated decrease in the yield spread associated with a one-point increase in ERI is in the order of two to four basis points, depending on the estimated model. The regression coefficients for ERI range between -0.0165 and -0.0322 . Since $\ln ($ Spread $)$ is in log-form, the coefficients translate into a $1.65-3.22 \%$ change in the cost of debt per unit change in the employee relations index. Based on a median Spread of 120 basis points, this effect is equivalent to an expected decrease of 1.98 to 3.86 basis points, per increase in ERI. Note that we use rounding to arrive at our final results.

Given that the median bond issue size is $\$ 300$ million, the effect of the decrease translates into a $\$ 60,000-\$ 120,000$ decrease in the annual interest expense per point increase in the employee relations index. As the sample range for ERI is 13 (i.e., from -4 to eight), the estimated maximum impact of ERI on the cost of debt ranges between 26-50 basis points $(\$ 780,000-\$ 1,500,000)$, or about $22-42 \%$ of the $\$ 3.6$ million annual median interest expense that is payable in excess of the Treasury benchmark rate.

\subsubsection{Employee relations and credit ratings}

\subsubsection{Bond ratings}

To show the bondholder-risk implications of employee relations, we conduct additional tests on the link between the quality of firms' employee relations and their bond ratings. The general model for bond ratings takes the form:

$$
\text { Bond Rating }_{i, t}=\alpha+\beta \text { ERI }_{i, t}+\sum_{k=1}^{K} \gamma_{k} \text { Issuer }_{k, i, t}+\sum_{l=1}^{L} \delta_{l} \text { Issue }_{l, i, t}+\varepsilon_{i, t}
$$

where Bond Rating is the credit rating assigned to a specific bond issue of a firm, and the $E R I$ and control variables are defined almost exactly as in model (1). The only difference vis-àvis the yield spread regression is that we exclude the Speculative variable in the set of issue characteristics, because its information content is inherent in the Bond Rating variable. Due to the ordinal in nature of credit ratings, we perform ordered probit regressions with year fixed effects to obtain coefficient estimates and corresponding $\mathrm{z}$-statistics. The significance of the co- 


\section{TABLE 2.5}

\section{Bond ratings regressions}

This table reports on ordered probit regressions of equally weighted S\&P and Moody's ratings (Bond Rating) on the employee relations index $(E R I)$, an array of issuer and issue specific determinants, and year effects. We extend the general model with union control (Union) and the governance index (Gindex). To ensure that the reduction in sample size caused by the inclusion of Gindex does not drive the results, we regress Bond Rating on the employee relations index using the limited sample (model (2c)) before including the Gindex in model (2d).

\begin{tabular}{|c|c|c|c|c|}
\hline & (2a) & $(2 b)$ & (2c) & $(2 d)$ \\
\hline ERI & $\begin{array}{l}0.1160 \text { *** } \\
(3.85)\end{array}$ & $\begin{array}{l}0.1140 \text { *** } \\
(3.48)\end{array}$ & $\begin{array}{l}0.1153^{* * *} \\
(2.78)\end{array}$ & $\begin{array}{l}0.1144 \text { *** } \\
(2.74)\end{array}$ \\
\hline Union & & $\begin{array}{l}-0.0084 * * \\
(-2.41)\end{array}$ & $\begin{array}{l}-0.0062 \\
(-1.36)\end{array}$ & $\begin{array}{l}-0.0063 \\
(-1.39)\end{array}$ \\
\hline Gindex & & & & $\begin{array}{l}0.0140 \\
(0.49)\end{array}$ \\
\hline Leverage & $\begin{array}{l}-0.0131 * * * * \\
(-3.35)\end{array}$ & $\begin{array}{l}-0.0117 * * * \\
(-2.86)\end{array}$ & $\begin{array}{l}-0.0098^{*} \\
(-1.82)\end{array}$ & $\begin{array}{l}-0.0096^{*} \\
(-1.80)\end{array}$ \\
\hline Size & $\begin{array}{l}0.4584 * * * \\
(9.35)\end{array}$ & $\begin{array}{l}0.4438 * * * \\
(7.98)\end{array}$ & $\begin{array}{l}0.4841 * * * \\
(6.70)\end{array}$ & $\begin{array}{l}0.4895^{* * * *} \\
(6.84)\end{array}$ \\
\hline Capital Intensity & $\begin{array}{l}0.0012 \\
(0.81)\end{array}$ & $\begin{array}{l}0.0028 \\
(1.60)\end{array}$ & $\begin{array}{l}0.0012 \\
(0.52)\end{array}$ & $\begin{array}{l}0.0012 \\
(0.52)\end{array}$ \\
\hline Interest Coverage & $\begin{array}{l}0.0341 * * * \\
(4.20)\end{array}$ & $\begin{array}{l}0.0302 * * * \\
(3.67)\end{array}$ & $\begin{array}{l}0.0377 * * * \\
(3.52)\end{array}$ & $\begin{array}{l}0.0380 * * * \\
(3.60)\end{array}$ \\
\hline ROA & $\begin{array}{l}0.0776 * * * \\
(5.66)\end{array}$ & $\begin{array}{l}0.0766^{* * * *} \\
(5.30)\end{array}$ & $\begin{array}{l}0.0898 * * * \\
(3.78)\end{array}$ & $\begin{array}{l}0.0902 * * * \\
(3.79)\end{array}$ \\
\hline Loss & $\begin{array}{l}-0.8039 * * * \\
(-3.24)\end{array}$ & $\begin{array}{l}-0.8403 * * * \\
(-3.09)\end{array}$ & $\begin{array}{l}-0.1778 \\
(-0.41)\end{array}$ & $\begin{array}{l}-0.1663 \\
(-0.38)\end{array}$ \\
\hline Subordinated & $\begin{array}{l}-1.2147 * * * \\
(-5.37)\end{array}$ & $\begin{array}{l}-1.2083 * * * \\
(-4.76)\end{array}$ & $\begin{array}{l}-1.0613 * * * \\
(-2.77)\end{array}$ & $\begin{array}{l}-1.0668 * * * \\
(-2.79)\end{array}$ \\
\hline TTM & $\begin{array}{l}0.0048^{*} \\
(1.85)\end{array}$ & $\begin{array}{l}0.0066^{* * * *} \\
(2.15)\end{array}$ & $\begin{array}{l}0.0073 * \\
(1.86)\end{array}$ & $\begin{array}{l}0.0071 * \\
(1.79)\end{array}$ \\
\hline Issue size & $\begin{array}{l}-0.0396 \\
(-0.73)\end{array}$ & $\begin{array}{l}-0.0923 \\
(-1.53)\end{array}$ & $\begin{array}{l}-0.1440^{*} \\
(-1.88)\end{array}$ & $\begin{array}{l}-0.1460 * \\
(-1.91)\end{array}$ \\
\hline Financial & $\begin{array}{l}0.7419 \text { *** } \\
(3.75)\end{array}$ & $\begin{array}{l}0.6865^{* * * *} \\
(3.30)\end{array}$ & $\begin{array}{l}0.6179 * * \\
(2.05)\end{array}$ & $\begin{array}{l}0.6047 * * \\
(2.03)\end{array}$ \\
\hline Utility & $\begin{array}{l}0.1719 \\
(0.88)\end{array}$ & $\begin{array}{l}0.1318 \\
(0.67)\end{array}$ & $\begin{array}{l}0.4036^{*} \\
(1.77)\end{array}$ & $\begin{array}{l}0.4047^{*} \\
(1.78)\end{array}$ \\
\hline Pseudo R² & 0.23 & 0.24 & 0.23 & 0.24 \\
\hline \# Observations & 2,265 & 2,265 & 1,895 & 823 \\
\hline
\end{tabular}

$* * * \mathrm{p}<0.01, * * \mathrm{p}<0.05, * \mathrm{p}<0.1$

Robust z-statistics in parentheses

Standard errors are heteroskedasticity robust and clustered at the firm 


\section{TABLE 2.6}

\section{Marginal effects analysis: Bond ratings}

This table reports the marginal effects for the bond rating analysis, based on the most comprehensive model specification. The marginal effects are nonlinear functions of the parameter estimates and the levels of the explanatory variables, i.e., they estimate the probability of a firm being ranked in a particular bond rating category (AAA, AA, AA, BBB, BB, B, or CCC-D) given a change in an explanatory variable, while holding the other variables fixed at the mean.

\begin{tabular}{|c|c|c|c|c|c|c|c|}
\hline & CCC-D & B & BB & BBB & A & AA & AAAA \\
\hline ERI & $\begin{array}{l}-0.0000 \\
(-0.83)\end{array}$ & $\begin{array}{l}-0.0009 * * \\
(-2.07)\end{array}$ & $\begin{array}{l}-0.0138 * * * \\
(-2.71)\end{array}$ & $\begin{array}{l}-0.0296^{* *} \\
(-2.47)\end{array}$ & $\begin{array}{l}0.0369 * * * \\
(2.72)\end{array}$ & $\begin{array}{l}0.0073 * * \\
(2.12)\end{array}$ & $\begin{array}{l}0.0001 \\
(1.22)\end{array}$ \\
\hline Union & $\begin{array}{l}0.0000 \\
(0.68)\end{array}$ & $\begin{array}{l}0.0001 \\
(1.27)\end{array}$ & $\begin{array}{l}0.0008 \\
(1.41)\end{array}$ & $\begin{array}{l}0.0016 \\
(1.34)\end{array}$ & $\begin{array}{l}-0.0020 \\
(-1.38)\end{array}$ & $\begin{array}{l}-0.0004 \\
(-1.32)\end{array}$ & $\begin{array}{l}-0.0000 \\
(-0.96)\end{array}$ \\
\hline Gindex & $\begin{array}{l}-0.0000 \\
(-0.43)\end{array}$ & $\begin{array}{l}-0.0001 \\
(-0.49)\end{array}$ & $\begin{array}{l}-0.0017 \\
(-0.48)\end{array}$ & $\begin{array}{l}-0.0036 \\
(-0.49)\end{array}$ & $\begin{array}{l}0.0045 \\
(0.48)\end{array}$ & $\begin{array}{l}0.0009 \\
(0.49)\end{array}$ & $\begin{array}{l}0.0000 \\
(0.44)\end{array}$ \\
\hline Leverage & $\begin{array}{l}0.0000 \\
(0.81)\end{array}$ & $\begin{array}{l}0.0001 \\
(1.53)\end{array}$ & $\begin{array}{l}0.0012^{*} \\
(1.66)\end{array}$ & $\begin{array}{l}0.0025^{*} \\
(1.79)\end{array}$ & $\begin{array}{l}-0.0031^{*} \\
(-1.76)\end{array}$ & $\begin{array}{l}-0.0006^{*} \\
(-1.76)\end{array}$ & $\begin{array}{l}-0.0000 \\
(-1.10)\end{array}$ \\
\hline Size & $\begin{array}{l}-0.0001 \\
(-0.84)\end{array}$ & $\begin{array}{l}-0.0039 * * \\
(-2.49)\end{array}$ & $\begin{array}{l}-0.0591 * * * \\
(-4.75)\end{array}$ & $\begin{array}{l}-0.1267 * * * \\
(-5.02)\end{array}$ & $\begin{array}{l}0.1580^{* * * *} \\
(6.09)\end{array}$ & $\begin{array}{l}0.0312 * * * \\
(3.40)\end{array}$ & $\begin{array}{l}0.0006 \\
(1.32)\end{array}$ \\
\hline Capital Intensity & $\begin{array}{l}-0.0000 \\
(-0.44)\end{array}$ & $\begin{array}{l}-0.0000 \\
(-0.50)\end{array}$ & $\begin{array}{l}-0.0001 \\
(-0.52)\end{array}$ & $\begin{array}{l}-0.0003 \\
(-0.52)\end{array}$ & $\begin{array}{l}0.0004 \\
(0.52)\end{array}$ & $\begin{array}{l}0.0001 \\
(0.52)\end{array}$ & $\begin{array}{l}0.0000 \\
(0.50)\end{array}$ \\
\hline Interest Coverage & $\begin{array}{l}-0.0000 \\
(-0.80)\end{array}$ & $\begin{array}{l}-0.0003 * * \\
(-2.06)\end{array}$ & $\begin{array}{l}-0.0046 * * * \\
(-2.99)\end{array}$ & $\begin{array}{l}-0.0098 * * * \\
(-3.38)\end{array}$ & $\begin{array}{l}0.0123 * * * \\
(3.62)\end{array}$ & $\begin{array}{l}0.0024^{* *} \\
(2.45)\end{array}$ & $\begin{array}{l}0.0000 \\
(1.16)\end{array}$ \\
\hline ROA & $\begin{array}{l}-0.0000 \\
(-0.84)\end{array}$ & $\begin{array}{l}-0.0007 * * \\
(-2.15)\end{array}$ & $\begin{array}{l}-0.0109 * * * \\
(-3.24)\end{array}$ & $\begin{array}{l}-0.0233 * * * \\
(-3.42)\end{array}$ & $\begin{array}{l}0.0291 * * * \\
(3.56)\end{array}$ & $\begin{array}{l}0.0057 * * * \\
(2.97)\end{array}$ & $\begin{array}{l}0.0001 \\
(1.37)\end{array}$ \\
\hline $\mathrm{Loss}^{+}$ & $\begin{array}{l}0.0000 \\
(0.28)\end{array}$ & $\begin{array}{l}0.0016 \\
(0.31)\end{array}$ & $\begin{array}{l}0.0224 \\
(0.35)\end{array}$ & $\begin{array}{l}0.0389 \\
(0.43)\end{array}$ & $\begin{array}{l}-0.0537 \\
(-0.39)\end{array}$ & $\begin{array}{l}-0.0091 \\
(-0.44)\end{array}$ & $\begin{array}{l}-0.0002 \\
(-0.45)\end{array}$ \\
\hline Subordinated $^{+}$ & $\begin{array}{l}0.0014 \\
(0.77)\end{array}$ & $\begin{array}{l}0.0361 \\
(1.14)\end{array}$ & $\begin{array}{l}0.2215^{* *} \\
(2.04)\end{array}$ & $\begin{array}{l}0.0561 \\
(0.71)\end{array}$ & $\begin{array}{l}-0.2867 * * * \\
(-4.13)\end{array}$ & $\begin{array}{l}-0.0280^{* * * *} \\
(-3.22)\end{array}$ & $\begin{array}{l}-0.0003 \\
(-1.20)\end{array}$ \\
\hline Time-to-maturity & $\begin{array}{l}-0.0000 \\
(-0.75)\end{array}$ & $\begin{array}{l}-0.0001 \\
(-1.47)\end{array}$ & $\begin{array}{l}-0.0009 * \\
(-1.66)\end{array}$ & $\begin{array}{l}-0.0018^{*} \\
(-1.78)\end{array}$ & $\begin{array}{l}0.0023 * \\
(1.77)\end{array}$ & $\begin{array}{l}0.0005^{*} \\
(1.66)\end{array}$ & $\begin{array}{l}0.0000 \\
(1.07)\end{array}$ \\
\hline Issue size & $\begin{array}{l}0.0000 \\
(0.76)\end{array}$ & $\begin{array}{l}0.0012 \\
(1.55)\end{array}$ & $\begin{array}{l}0.0176^{*} \\
(1.71)\end{array}$ & $\begin{array}{l}0.0378^{*} \\
(1.94)\end{array}$ & $\begin{array}{l}-0.0471^{*} \\
(-1.89)\end{array}$ & $\begin{array}{l}-0.0093^{*} \\
(-1.79)\end{array}$ & $\begin{array}{l}-0.0002 \\
(-1.02)\end{array}$ \\
\hline Financial $^{+}$ & $\begin{array}{l}-0.0000 \\
(-0.80)\end{array}$ & $\begin{array}{l}-0.0029 * \\
(-1.88)\end{array}$ & $\begin{array}{l}-0.0534 * * \\
(-2.43)\end{array}$ & $\begin{array}{l}-0.1813^{*} \\
(-1.92)\end{array}$ & $\begin{array}{l}0.1777 * * \\
(2.35)\end{array}$ & $\begin{array}{l}0.0582 \\
(1.45)\end{array}$ & $\begin{array}{l}0.0017 \\
(0.90)\end{array}$ \\
\hline Utility $^{+}$ & $\begin{array}{l}-0.0000 \\
(-0.77)\end{array}$ & $\begin{array}{l}-0.0021 * \\
(-1.71)\end{array}$ & $\begin{array}{l}-0.0382 * * \\
(-2.02)\end{array}$ & $\begin{array}{l}-0.1196^{*} \\
(-1.66)\end{array}$ & $\begin{array}{l}0.1237 * * \\
(1.96)\end{array}$ & $\begin{array}{l}0.0354 \\
(1.27)\end{array}$ & $\begin{array}{l}0.0009 \\
(0.79)\end{array}$ \\
\hline
\end{tabular}

$* * * \mathrm{p}<0.01, * * \mathrm{p}<0.05, * \mathrm{p}<0.1$

${ }^{+} d y / d x$ is for discrete change of dummy variable from 0 to 1 
efficients is again based on heteroskedasticity robust standard errors that are clustered at the firm level.

The results in Table 2.5 show that most coefficients on the control variables are statistically significant and have signs consistent with prior studies. Although the coefficient on TTM is positive and statistically significant, and therefore not in line with the predicted sign, this empirical result is not unique to this study (see Bhojraj and Sengupta, 2003). Most importantly, and in line with our second hypothesis, all models in Table 2.5 consistently produce positive and statistically significant coefficients on the ERI variable. This finding implies that the better the quality of employee relations, the greater the likelihood of a higher bond rating and a lower bond risk.

To derive an economic interpretation of ordered probit regression coefficients in Table 2.5, we calculate marginal effects. The marginal effects predict how a change in the ERI translates into the probability of observing a particular bond rating category, while holding the other explanatory variables fixed at their means.

The marginal effects analysis shows that an increase in the ERI reduces the probability of being rated $\mathrm{BBB}$ or lower, and increases the probability of being rated A or higher: If ERI increases by one point, we expect the probabilities of receiving a $\mathrm{BBB}, \mathrm{BB}$, or $\mathrm{B}$ to decrease by $2.96 \%, 1.38 \%$, and $0.1 \%$ respectively. By contrast, the probabilities of obtaining an A and AA bond rating are expected to increase by $3.69 \%$ and $0.73 \%$ respectively.

\subsubsection{Issuer ratings}

To reinforce our evidence on the connection between employee relations and credit risk, we augment our bond ratings analyses with tests in which we use a more comprehensive sample of long-term issuer ratings. The general model for the issuer ratings takes the form:

$$
\text { Issuer Rating }_{i, t}=\alpha+\beta E R I_{i, t}+\sum_{k=1}^{K} \gamma_{k} \text { Issuer }_{k, i, t}+\varepsilon_{i, t}
$$

Since issuer ratings pertain to the general creditworthiness of a rated entity rather than a particular bond issue, Model (3) includes only the firm specific characteristics of the bond issuer as control variables. We again perform ordered probit regressions with year fixed effects to estimate the Issuer Rating model.

Table 2.7 shows that all models consistently produce positive and statistically significant loadings on the ERI variable, which provides additional support for the idea that stronger employee relations are associated with higher credit ratings and lower credit risk. Again, the coefficients of the control variables remain mostly statistically significant and have the expected signs.

Table 2.8 reports the corresponding marginal effects analysis, which corresponds with the results reported in the preceding bond ratings analysis. 


\section{TABLE 2.7}

\section{Long-term issuer ratings regressions}

This table reports results for the additional test of the association between the quality of employee relations and credit ratings. We implement ordered probit regressions of S\&P long-term domestic issuer ratings (Issuer Rating) on the employee relations index $(E R I)$, while controlling for a set of issuer specific determinants and year effects. We extend the general model with union control (Union) and the governance index (Gindex). Including the Gindex substantially reduces the sample, as it is only available for a subset of the sample years. To ensure that the reduction in sample size caused by the inclusion of Gindex does not drive our results, we regress Issuer Rating on the employee relations index using the limited sample, model (3c), before including the Gindex in model (3d). We note that Subordinated here denotes a dummy variable that equals one if a firm holds subordinated debt (data80) in its capital structure, and zero otherwise.

\begin{tabular}{|c|c|c|c|c|}
\hline & (3a) & $(3 b)$ & $(3 c)$ & $(3 d)$ \\
\hline ERI & $\begin{array}{l}0.0574 * * * \\
(2.59)\end{array}$ & $\begin{array}{l}0.0539 * * \\
(2.43)\end{array}$ & $\begin{array}{l}0.0501 * * \\
(2.23)\end{array}$ & $\begin{array}{l}0.0486^{* *} \\
(2.16)\end{array}$ \\
\hline Union & & $\begin{array}{l}-0.0043 \\
(-1.28)\end{array}$ & $\begin{array}{l}-0.0039 \\
(-1.11)\end{array}$ & $\begin{array}{l}-0.0040 \\
(-1.15)\end{array}$ \\
\hline Gindex & & & & $\begin{array}{l}0.0232 \\
(1.55)\end{array}$ \\
\hline Leverage & $\begin{array}{l}-0.0100 * * * \\
(-4.86)\end{array}$ & $\begin{array}{l}-0.0098 * * * \\
(-4.75)\end{array}$ & $\begin{array}{l}-0.0121 * * * \\
(-5.14)\end{array}$ & $\begin{array}{l}-0.0121 * * * \\
(-5.15)\end{array}$ \\
\hline Size & $\begin{array}{l}0.4773 * * * \\
(14.95)\end{array}$ & $\begin{array}{l}0.4840 * * * \\
(15.01)\end{array}$ & $\begin{array}{l}0.4921 * * * \\
(13.48)\end{array}$ & $\begin{array}{l}0.4959 * * * \\
(13.58)\end{array}$ \\
\hline Capital Intensity & $\begin{array}{l}0.0006 \\
(0.57)\end{array}$ & $\begin{array}{l}0.0010 \\
(1.10)\end{array}$ & $\begin{array}{l}0.0005 \\
(0.47)\end{array}$ & $\begin{array}{l}0.0004 \\
(0.40)\end{array}$ \\
\hline Interest Coverage & $\begin{array}{l}0.0006 \\
(0.54)\end{array}$ & $\begin{array}{l}0.0005 \\
(0.47)\end{array}$ & $\begin{array}{l}-0.0004 \\
(-0.37)\end{array}$ & $\begin{array}{l}-0.0003 \\
(-0.27)\end{array}$ \\
\hline ROA & $\begin{array}{l}0.0615 * * * \\
(11.88)\end{array}$ & $\begin{array}{l}0.0611 * * * \\
(11.79)\end{array}$ & $\begin{array}{l}0.0690 * * * \\
(10.48)\end{array}$ & $\begin{array}{l}0.0693 * * * \\
(10.45)\end{array}$ \\
\hline Loss & $\begin{array}{l}-0.3927 * * * \\
(-4.14)\end{array}$ & $\begin{array}{l}-0.4001 * * * \\
(-4.19)\end{array}$ & $\begin{array}{l}-0.3283 * * * \\
(-2.38)\end{array}$ & $\begin{array}{l}-0.3111 * * * \\
(-2.25)\end{array}$ \\
\hline Subordinated & $\begin{array}{l}-0.3413 * * * \\
(-4.81)\end{array}$ & $\begin{array}{l}-0.3476 * * * \\
(-4.85)\end{array}$ & $\begin{array}{l}-0.3719 * * * \\
(-4.62)\end{array}$ & $\begin{array}{l}-0.3645^{* * *} \\
(-4.45)\end{array}$ \\
\hline Financial & $\begin{array}{l}0.4901 * * * \\
(4.28)\end{array}$ & $\begin{array}{l}0.4635^{* * * *} \\
(3.89)\end{array}$ & $\begin{array}{l}0.5136^{* * * *} \\
(3.88)\end{array}$ & $\begin{array}{l}0.5148 * * * \\
(3.84)\end{array}$ \\
\hline Utility & $\begin{array}{l}0.8460 \\
(0.72)\end{array}$ & $\begin{array}{l}0.8794 \\
(0.74)\end{array}$ & $\begin{array}{l}-0.3210 \\
(-0.30)\end{array}$ & $\begin{array}{l}-0.3188 \\
(-0.30)\end{array}$ \\
\hline Pseudo R ${ }^{2}$ & 0.19 & 0.19 & 0.18 & 0.18 \\
\hline \# Observations & 5,568 & 5,568 & 2,421 & 2,421 \\
\hline
\end{tabular}

$* * * \mathrm{p}<0.01, * * \mathrm{p}<0.05, * \mathrm{p}<0.1$

Robust z-statistics in parentheses

Standard errors are heteroskedasticity robust and clustered at the firm 


\section{TABLE 2.8}

\section{Marginal effects analysis: Issuer ratings}

This table reports the marginal effects for the issuer rating analysis, based on the most comprehensive model specification. The marginal effects are nonlinear functions of the parameter estimates and the levels of the explanatory variables, i.e., they estimate the probability of a firm being ranked in a particular bond rating category (AAA, AA, AA, BBB, BB, B, or CCC-D) given a change in an explanatory variable, while holding the other variables fixed at the mean.

\begin{tabular}{|c|c|c|c|c|c|c|c|}
\hline & CCC-D & B & BB & BBB & $\mathbf{A}$ & $\mathbf{A A}$ & $\mathbf{A A A}$ \\
\hline ERI & $\begin{array}{l}-0.0000 \\
(-1.17)\end{array}$ & $\begin{array}{l}-0.0065^{* *} \\
(-2.21)\end{array}$ & $\begin{array}{l}-0.0114 * * \\
(-2.10)\end{array}$ & $\begin{array}{l}0.0032 * \\
(1.91)\end{array}$ & $\begin{array}{l}0.0132 * * \\
(2.14)\end{array}$ & $\begin{array}{l}0.0013 * * \\
(1.97)\end{array}$ & $\begin{array}{l}0.0002 \\
(1.48)\end{array}$ \\
\hline Union & $\begin{array}{l}0.0000 \\
(0.88)\end{array}$ & $\begin{array}{l}0.0005 \\
(1.15)\end{array}$ & $\begin{array}{l}0.0009 \\
(1.14)\end{array}$ & $\begin{array}{l}-0.0003 \\
(-1.12)\end{array}$ & $\begin{array}{l}-0.0011 \\
(-1.14)\end{array}$ & $\begin{array}{l}-0.0001 \\
(-1.11)\end{array}$ & $\begin{array}{l}-0.0000 \\
(-0.95)\end{array}$ \\
\hline Gindex & $\begin{array}{l}-0.0000 \\
(-1.01)\end{array}$ & $\begin{array}{l}-0.0031 \\
(-1.52)\end{array}$ & $\begin{array}{l}-0.0055 \\
(-1.54)\end{array}$ & $\begin{array}{l}0.0015 \\
(1.43)\end{array}$ & $\begin{array}{l}0.0063 \\
(1.54)\end{array}$ & $\begin{array}{l}0.0006 \\
(1.46)\end{array}$ & $\begin{array}{l}0.0001 \\
(1.22)\end{array}$ \\
\hline Leverage & $\begin{array}{l}0.0000 \\
(1.25)\end{array}$ & $\begin{array}{l}0.0016^{* * *} \\
(4.55)\end{array}$ & $\begin{array}{l}0.0028 * * * \\
(4.79)\end{array}$ & $\begin{array}{l}-0.0008 * * * \\
(-2.98)\end{array}$ & $\begin{array}{l}-0.0033^{* * * *} \\
(-5.01)\end{array}$ & $\begin{array}{l}-0.0003 * * * \\
(-3.24)\end{array}$ & $\begin{array}{l}-0.0000^{*} \\
(-1.70)\end{array}$ \\
\hline Size & $\begin{array}{l}-0.0005 \\
(-1.26)\end{array}$ & $\begin{array}{l}-0.0663 * * * \\
(-8.77)\end{array}$ & $\begin{array}{l}-0.1165 * * * \\
(-9.26)\end{array}$ & $\begin{array}{l}0.0330 * * * \\
(3.80)\end{array}$ & $\begin{array}{l}0.1350^{* * * *} \\
(10.87)\end{array}$ & $\begin{array}{l}0.0135 * * * \\
(3.80)\end{array}$ & $\begin{array}{l}0.0017^{*} \\
(1.73)\end{array}$ \\
\hline Capital Intensity & $\begin{array}{l}-0.0000 \\
(-0.39)\end{array}$ & $\begin{array}{l}-0.0001 \\
(-0.40)\end{array}$ & $\begin{array}{l}-0.0001 \\
(-0.40)\end{array}$ & $\begin{array}{l}0.0000 \\
(0.40)\end{array}$ & $\begin{array}{l}0.0001 \\
(0.40)\end{array}$ & $\begin{array}{l}0.0000 \\
(0.40)\end{array}$ & $\begin{array}{l}0.0000 \\
(0.41)\end{array}$ \\
\hline Interest Coverage & $\begin{array}{l}0.0000 \\
(0.26)\end{array}$ & $\begin{array}{l}0.0000 \\
(0.27)\end{array}$ & $\begin{array}{l}0.0001 \\
(0.27)\end{array}$ & $\begin{array}{l}-0.0000 \\
(-0.27)\end{array}$ & $\begin{array}{l}-0.0001 \\
(-0.27)\end{array}$ & $\begin{array}{l}-0.0000 \\
(-0.27)\end{array}$ & $\begin{array}{l}-0.0000 \\
(-0.27)\end{array}$ \\
\hline ROA & $\begin{array}{l}-0.0001 \\
(-1.24)\end{array}$ & $\begin{array}{l}-0.0093 * * * \\
(-6.98)\end{array}$ & $\begin{array}{l}-0.0163 * * * \\
(-8.51)\end{array}$ & $\begin{array}{l}0.0046^{* * * *} \\
(3.72)\end{array}$ & $\begin{array}{l}0.0189 * * * \\
(8.89)\end{array}$ & $\begin{array}{l}0.0019 * * * \\
(3.61)\end{array}$ & $\begin{array}{l}0.0002^{*} \\
(1.73)\end{array}$ \\
\hline $\mathrm{Loss}^{+}$ & $\begin{array}{l}0.0005 \\
(1.15)\end{array}$ & $\begin{array}{l}0.0505^{*} \\
(1.84)\end{array}$ & $\begin{array}{l}0.0687 * * \\
(2.46)\end{array}$ & $\begin{array}{l}-0.0356 \\
(-1.57)\end{array}$ & $\begin{array}{l}-0.0771^{* *} \\
(-2.52)\end{array}$ & $\begin{array}{l}-0.0063^{* *} \\
(-2.41)\end{array}$ & $\begin{array}{l}-0.0007 \\
(-1.46)\end{array}$ \\
\hline Subordinated $^{+}$ & $\begin{array}{l}0.0005 \\
(1.24)\end{array}$ & $\begin{array}{l}0.0582 * * * \\
(3.85)\end{array}$ & $\begin{array}{l}0.0809^{* * * *} \\
(4.34)\end{array}$ & $\begin{array}{l}-0.0398^{* * * *} \\
(-3.09)\end{array}$ & $\begin{array}{l}-0.0912^{* * *} \\
(-4.68)\end{array}$ & $\begin{array}{l}-0.0077 * * * \\
(-3.09)\end{array}$ & $\begin{array}{l}-0.0009 \\
(-1.61)\end{array}$ \\
\hline Financial $^{+}$ & $\begin{array}{l}-0.0003 \\
(-1.18)\end{array}$ & $\begin{array}{l}-0.0509 * * * \\
(-4.39)\end{array}$ & $\begin{array}{l}-0.1196^{* * *} \\
(-3.94)\end{array}$ & $\begin{array}{l}-0.0056 \\
(-0.42)\end{array}$ & $\begin{array}{l}0.1509 * * * \\
(3.66)\end{array}$ & $\begin{array}{l}0.0219 * * \\
(2.39)\end{array}$ & $\begin{array}{l}0.0036^{*} \\
(1.65)\end{array}$ \\
\hline Utility $^{+}$ & $\begin{array}{l}0.0005 \\
(0.18)\end{array}$ & $\begin{array}{l}0.0531 \\
(0.25)\end{array}$ & $\begin{array}{l}0.0696 \\
(0.33)\end{array}$ & $\begin{array}{l}-0.0385 \\
(-0.21)\end{array}$ & $\begin{array}{l}-0.0778 \\
(-0.34)\end{array}$ & $\begin{array}{l}-0.0062 \\
(-0.44)\end{array}$ & $\begin{array}{l}-0.0007 \\
(-0.51)\end{array}$ \\
\hline
\end{tabular}

$* * * \mathrm{p}<0.01, * * \mathrm{p}<0.05, * \mathrm{p}<0.1$

${ }^{+} d y / d x$ is for discrete change of dummy variable from 0 to 1

\subsubsection{Additional tests}

\subsubsection{Endogeneity}

We perform a robustness test that manages possible endogeneity bias in our research design. We investigate the association between the yield spread and ERI by using a two-stage least squares approach, which allows the employee relations index to be endogenous.

One of the main problems of the approach concerns the identification of appropriate instrumental variables that are uncorrelated with the errors of the structural yield spread equation and partially correlated with the endogenous independent variable. We define the instrument as the firm's number of employees adjusted for the industry average number of em- 


\section{TABLE 2.9}

\section{Controlling for endogeneity: Two-stage instrumental variable tests (2nd stage)}

Reported are the second-stage results for the two-stage least squares (2SLS) tests. We implement instrumental variable regressions of the log-transformed yield spread $(\ln ($ Spread $))$ on the instrumented employee relations index $\left(E R I^{+}\right)$, while controlling for an array of issuer and issue specific determinants and for year effects. We compute the instrumental variable as the ratio of the number of employees in the firm (data29) divided by the average number of employees in the firm's three-digit SIC industry. Consistent with our previous tests, we gradually extend the general model to account for the level of union control (Union) and the governance structure of the firm (Gindex).

\begin{tabular}{|c|c|c|c|c|}
\hline & $\left(1 \mathrm{a}^{+}\right)$ & $\left(1 b^{+}\right)$ & $\left(1 c^{+}\right)$ & $\left(1 d^{+}\right)$ \\
\hline $\mathrm{ERI}^{+}$ & $\begin{array}{l}-0.1385^{* * *} \\
(-4.00)\end{array}$ & $\begin{array}{l}-0.1817 * * * \\
(-3.83)\end{array}$ & $\begin{array}{l}-0.2465^{* * *} \\
(-4.21)\end{array}$ & $\begin{array}{l}-0.2339 * * * \\
(-4.28)\end{array}$ \\
\hline Union & & $\begin{array}{l}-0.0021 \\
(-1.47)\end{array}$ & $\begin{array}{l}-0.0046^{* *} \\
(-2.16)\end{array}$ & $\begin{array}{l}-0.0044 * * \\
(-2.22)\end{array}$ \\
\hline Gindex & & & & $\begin{array}{l}0.0105 \\
(1.01)\end{array}$ \\
\hline Leverage & $\begin{array}{l}0.0037 * * * \\
(2.57)\end{array}$ & $\begin{array}{l}0.0032 * \\
(1.93)\end{array}$ & $\begin{array}{l}0.0019 \\
(0.88)\end{array}$ & $\begin{array}{l}0.0018 \\
(0.91)\end{array}$ \\
\hline Size & $\begin{array}{l}-0.0852 * * * \\
(-3.40)\end{array}$ & $\begin{array}{l}-0.0728 * * \\
(-2.48)\end{array}$ & $\begin{array}{l}-0.0098 \\
(-0.19)\end{array}$ & $\begin{array}{l}-0.0116 \\
(-0.24)\end{array}$ \\
\hline Capital Intensity & $\begin{array}{l}-0.0005 \\
(-1.16)\end{array}$ & $\begin{array}{l}-0.0006 \\
(-0.94)\end{array}$ & $\begin{array}{l}-0.0008 \\
(-0.95)\end{array}$ & $\begin{array}{l}-0.0008 \\
(-0.98)\end{array}$ \\
\hline Interest Coverage & $\begin{array}{l}-0.0014 \\
(-0.49)\end{array}$ & $\begin{array}{l}-0.0010 \\
(-0.33)\end{array}$ & $\begin{array}{l}-0.0018 \\
(-0.38)\end{array}$ & $\begin{array}{l}-0.0020 \\
(-0.44)\end{array}$ \\
\hline ROA & $\begin{array}{l}-0.0256 * * * \\
(-6.54)\end{array}$ & $\begin{array}{l}-0.0236 * * * \\
(-4.73)\end{array}$ & $\begin{array}{l}-0.0181 * * * \\
(-2.73)\end{array}$ & $\begin{array}{l}-0.0182 * * * \\
(-2.87)\end{array}$ \\
\hline Loss & $\begin{array}{l}0.1781^{*} \\
(1.86)\end{array}$ & $\begin{array}{l}0.2185^{*} \\
(1.92)\end{array}$ & $\begin{array}{l}0.4338^{* *} \\
(2.23)\end{array}$ & $\begin{array}{l}0.4316^{* *} \\
(2.31)\end{array}$ \\
\hline Subordinate & $\begin{array}{l}0.2245^{* * * *} \\
(3.06)\end{array}$ & $\begin{array}{l}0.2677 * * * \\
(2.79)\end{array}$ & $\begin{array}{l}0.2037^{*} \\
(1.75)\end{array}$ & $\begin{array}{l}0.1978^{*} \\
(1.75)\end{array}$ \\
\hline TTM & $\begin{array}{l}0.0106^{* * *} \\
(8.95)\end{array}$ & $\begin{array}{l}0.0111^{* * * *} \\
(7.75)\end{array}$ & $\begin{array}{l}0.0125^{* * * *} \\
(6.65)\end{array}$ & $\begin{array}{l}0.0123 * * * \\
(6.73)\end{array}$ \\
\hline Issue Size & $\begin{array}{l}0.0577 * * * \\
(2.26)\end{array}$ & $\begin{array}{l}0.0685^{* *} \\
(2.08)\end{array}$ & $\begin{array}{l}0.0557 \\
(1.17)\end{array}$ & $\begin{array}{l}0.0505 \\
(1.09)\end{array}$ \\
\hline Speculative & $\begin{array}{l}0.6409 * * * \\
(15.11)\end{array}$ & $\begin{array}{l}0.6504 * * * \\
(12.07)\end{array}$ & $\begin{array}{l}0.5692 * * * \\
(7.18)\end{array}$ & $\begin{array}{l}0.5851 \text { *** } \\
(7.61)\end{array}$ \\
\hline Financial & $\begin{array}{l}0.0026 \\
(0.04)\end{array}$ & $\begin{array}{l}0.0282 \\
(0.35)\end{array}$ & $\begin{array}{l}-0.0080 \\
(-0.07)\end{array}$ & $\begin{array}{l}-0.0112 \\
(-0.11)\end{array}$ \\
\hline Utility & $\begin{array}{l}0.0605 \\
(1.16)\end{array}$ & $\begin{array}{l}0.0862 \\
(1.40)\end{array}$ & $\begin{array}{l}0.1424 \\
(1.50)\end{array}$ & $\begin{array}{l}0.1405 \\
(1.53)\end{array}$ \\
\hline Pseudo R² & 0.55 & 0.46 & 0.22 & 0.28 \\
\hline Wald $\chi^{2}$ & 2,390 & 1,476 & 586 & 654 \\
\hline \# Observations & 2,106 & 1,758 & 767 & 767 \\
\hline
\end{tabular}

*** $\mathrm{p}<0.01, * * \mathrm{p}<0.05, * \mathrm{p}<0.1$

Robust z-statistics in parentheses

Standard errors are heteroskedasticity robust and clustered at the firm 
ployees. We base our choice of instrumental variable on the logic that firms should become more inclined to properly manage employee relations as they become more dependent on human resources. By using industry-adjusted values, we control for the possibility that the number of employees in a firm is affected by industry-wide employment conditions (e.g., rate of unemployment).

The (unreported) first-stage regression confirms that the number of employees is relevant for the determination of employee relations. Table 2.9 corroborates our earlier findings of a negative relation between ERI and the yield spread. The negative loading on the instrumentalized employee relations index, $E R I^{+}$, remains economically and statistically significant.

\subsubsection{ERI composition}

Although our measure for the quality of employee relations comprises KLD's entire spectrum of employment-related performance indicators, two of these indicators may deserve further attention.

First, KLD defines the "Union Relations" indicators as proxies for the general quality of a firm's union relations, and evaluates these indicators according to the firm's history of treating unions fairly. Although these indicators do not necessarily provide any clues about the influence that unions exercise over a firm's operations, we cannot rule out the possibility that the quality of union relations is correlated with the Union control variable. Second, KLD does not detail the performance criteria that it uses to evaluate the indicators in the Other category (e.g., Other Diversity Management Strengths). These indicators are broadly described as capturing employment-related strengths and concerns other than those that KLD explicitly lists in its respective dimensions, and we cannot clearly identify what information they comprise.

We tackle the ambiguity surrounding the "Union Relations" and "Other" indicators by excluding these categories from the employee relations index and repeating our tests. The (unreported) results for the modified ERI are statistically and economically similar to our main results. ${ }^{7}$ We therefore conclude that our main findings are not driven by these omitted indicators.

\subsubsection{Industry effects}

We next account for possible industry differences that may be driving our outcomes for the employee relations index, and extend our models with one-digit SIC industry dummies. (We note that the inclusion of the industry dummies requires the removal of the Financial and Utility dummies to avoid multicollinearity problems.) Table 2.10 shows the regression results for the most comprehensive Spread, Bond Rating, and Issuer Rating model.

The control variables are generally significant and carry their expected signs. Furthermore, the coefficients on Union become statistically significant. The loading on Union in the Spread regression confirms the negative relation that Chen et al. (2008a) report. A somewhat surprising result is the negative relation between the Union variable and credit ratings. One explanation for this conflicting finding is that strong union control can convey a mixed signal to the market: Faleye et al. (2006) document that labor control is associated with a reduction in

\footnotetext{
${ }^{7}$ All test results for the modified employee relations index are available from the authors on request.
} 


\section{TABLE 2.10}

\section{Employee relations and credit risk - Industry fixed effects}

This table shows the regression results of the most comprehensive Spread, Bond Rating, and Issuer Rating model (i.e., 1d, 2d, 3d), which we extend by using industry effects at the one-digit SIC level. We implement pooled OLS tests for the Spread model and ordered probit regressions for both credit rating categories, on the employee relations index $(E R I)$ and an array of issuer and issue specific control variables.

\begin{tabular}{|c|c|c|c|}
\hline & $\ln ($ Spread $)$ & Bond Ratings & Issuer Ratings \\
\hline ERI & $\begin{array}{l}-0.0253^{* *} \\
(-2.54)\end{array}$ & $\begin{array}{l}0.1111 * * * \\
(2.61)\end{array}$ & $\begin{array}{l}0.0253 \\
(1.06)\end{array}$ \\
\hline Union & $\begin{array}{l}-0.0024 * * \\
(-2.48)\end{array}$ & $\begin{array}{l}-0.0086^{* *} \\
(-1.98)\end{array}$ & $\begin{array}{l}-0.0076^{* *} \\
(-1.97)\end{array}$ \\
\hline Gindex & $\begin{array}{l}0.0094 \\
(1.47)\end{array}$ & $\begin{array}{l}0.0194 \\
(0.66)\end{array}$ & $\begin{array}{l}0.0187 \\
(1.23)\end{array}$ \\
\hline Leverage & $\begin{array}{l}0.0016 \\
(1.33)\end{array}$ & $\begin{array}{l}-0.0061 \\
(-1.30)\end{array}$ & $\begin{array}{l}-0.0122 * * * \\
(-5.17)\end{array}$ \\
\hline Size & $\begin{array}{l}-0.1294 * * * \\
(-7.30)\end{array}$ & $\begin{array}{l}0.5348^{* * * *} \\
(7.51)\end{array}$ & $\begin{array}{l}0.5368 * * * \\
(14.02)\end{array}$ \\
\hline Capital Intensity & $\begin{array}{l}-0.0014 * * * \\
(-2.69)\end{array}$ & $\begin{array}{l}0.0003 \\
(0.13)\end{array}$ & $\begin{array}{l}0.0013 \\
(1.08)\end{array}$ \\
\hline Interest Coverage & $\begin{array}{l}-0.0077 * * * \\
(-3.98)\end{array}$ & $\begin{array}{l}0.0413 * * * \\
(4.00)\end{array}$ & $\begin{array}{l}0.0000 \\
(0.00)\end{array}$ \\
\hline ROA & $\begin{array}{l}-0.0213 * * * \\
(-5.00)\end{array}$ & $\begin{array}{l}0.0748^{* * * *} \\
(3.32)\end{array}$ & $\begin{array}{l}0.0656^{* * * *} \\
(9.90)\end{array}$ \\
\hline Loss & $\begin{array}{l}0.3096^{* * * *} \\
(2.74)\end{array}$ & $\begin{array}{l}-0.3678 \\
(-0.90)\end{array}$ & $\begin{array}{l}-0.3437 * * \\
(-2.41)\end{array}$ \\
\hline Subordinated & $\begin{array}{l}0.2239 * * * \\
(3.40)\end{array}$ & $\begin{array}{l}-1.0169 * * \\
(-2.56)\end{array}$ & $\begin{array}{l}-0.3274 * * * \\
(-4.12)\end{array}$ \\
\hline TTM & $\begin{array}{l}0.0125 \text { *** } \\
(8.26)\end{array}$ & $\begin{array}{l}0.0078 * \\
(1.91)\end{array}$ & \\
\hline Issue Size & $\begin{array}{l}-0.0190 \\
(-0.49)\end{array}$ & $\begin{array}{l}-0.2191 * * * \\
(-2.97)\end{array}$ & \\
\hline Speculative & $\begin{array}{l}0.5918^{* * * *} \\
(11.25)\end{array}$ & & \\
\hline Year Fixed Effects & Yes & Yes & Yes \\
\hline Industry Fixed Effects & Yes & Yes & Yes \\
\hline Adjusted R² / Pseudo R² & 0.64 & 0.24 & 0.21 \\
\hline \# Observations & 790 & 823 & 2,421 \\
\hline
\end{tabular}

*** $\mathrm{p}<0.01, * * \mathrm{p}<0.05, * \mathrm{p}<0.1$

Robust t- or z-statistics in parentheses

Standard errors are heteroskedasticity robust and clustered at the firm level 
the firm's operating risk, as measured by the standard deviation of ROA, and lower R\&D spending. This relation is consistent with Chen et al.'s (2008b) view that risk-averse employees influence management decisions to reduce corporate risk taking, and in doing so lower the firm's default risk. By contrast, Faleye et al. demonstrate that labor-controlled firms deviate more from value maximization, invest less in long-term assets, grow more slowly, and exhibit lower labor and total factor productivity than do other firms. The latter findings predict an impaired financial outlook for the labor-controlled firm, and thereby imply a lower credit standing. Thus, the signal that strong union control conveys may be ambiguous.

Most importantly, the relation between ERI and both Spread and Bond Rating continue to be significant after including industry dummy variables. This result indicates that the association between the quality of firm's employee relations and their credit risk is not driven by industry differences. Although the ERI coefficient maintains its positive sign in the Issuer Rating regression, it is not statistically significant.

\subsubsection{Corporate governance effects}

The coefficients on the Gindex control variable are statistically nonsignificant throughout our analysis. Bebchuk et al. (2009) argue that only a subset of the governance provisions covered by the Gindex are relevant proxies for the takeover defenses of a firm, and instead suggest the use of a refined entrenchment index. We repeat our analysis using this alternative governance measure (unreported), and find that the coefficients on the entrenchment index remain statistically nonsignificant.

One possible explanation for the nonsignificance of the governance measures is that ERI is correlated with the entrenchment measures. Pagano and Volpin (2005) argue that if management has high private benefits and a small equity stake, then managers and workers are natural allies against takeover threats. Managers can entrench themselves by paying higher wages and issuing long-term labor contracts, thereby turning workers into effective barriers against hostile takeovers as they try protect these benefits. Cronqvist et al. (2009) provide empirical evidence that entrenched managers pay their workers higher wages.

To test whether ERI captures part of an entrenchment effect, we repeat our analysis and include the governance variables first, before adding the ERI in a subsequent stage. The (unreported) results confirm that neither Gindex nor the entrenchment index are significant determinants of credit risk before and after the addition of the ERI. One explanation for the insignificance of the governance measures is provided by Qui and Yu (2008), who report that the market for corporate control has virtually no effect on investment grade firms, which comprise about $87 \%$ of our sample.

Finally, we relax our assumptions on the clustering of the coefficient standard errors, and instead cluster them by three-digit SIC codes or CIC industry codes. We find that doing so boosts the statistical significance of the observed relation between ERI and our measures of credit risk.

\subsubsection{Cash flow risk and equity risk}

The credit risk analyses are consistent with the idea that strong employee relations reduce employment-related risks and improve the firm's financial health. Given that litigation, reputation, and other human capital risks are mainly firm-specific in nature, we expect that $E R I$ 
is also negatively associated with other measures of firm risk. To investigate this possibility, we estimate regression models of the firm's cash flow volatility as well as alternative stock-based volatility measures (i.e., total equity volatility, systematic risk, and idiosyncratic volatility).

We collect data for 976 firms over the 1995-2006 period using CRSP and Compustat. ${ }^{8}$ As our proxy for cash flow volatility, we use the standard deviation of the firm's return on assets $\left(\sigma_{R O A}\right)$ over the previous 15 quarterly observations. Although the volatility of ROA is commonly used in empirical studies, the measurement of ROA is vulnerable to estimation errors caused by small-sample issues (low frequency data) and sensitive to managers' latitude. Therefore, we extend the cash flow volatility analysis by using tests on the association between $E R I$ and risk measures that we base on the firm's stock returns. We estimate these market-based measures with higher-frequency data, so they are arguably more reliable than accounting-based measures. We define total equity volatility $\left(\sigma_{R E T}\right)$ as the annual standard deviation of daily stock returns. We define systematic risk $\left(\beta_{M K T}\right)$ as the beta coefficient from Sharpe's (1964) Capital Asset Pricing Model (CAPM), and estimate it using monthly stock returns over the previous five years. We define idiosyncratic volatility $\left(\sigma_{r e s}\right)$ as the standard deviation of residuals from the CAPM regression and use it to measure firm-specific equity risk.

Our choice of control variables for the supplementary risk analysis is based on previous empirical studies (e.g., Cheung and Ng, 1992; Bushee and Noe, 2000; Ashbaugh et al., 2000; Gaspar and Massa, 2006; John et al., 2008). We define the variables Union, Size, and Leverage identically to those of the preceding analyses. Tobin's Q is the natural logarithm of the firm's market value of assets (data181 + data25* data199 + data10 - data35) divided by total assets (data6). We define Profit as operating income (data13) divided by total assets; and define Total payout as dividends (data19 + data $21+$ data127) plus repurchases (data115) divided by total assets. We measure Invest by the natural logarithm of capital expenditure (data128) divided by net property, plant, and equipment (data8). Business Concentration is the natural logarithm of a Herfindahl Index measuring the concentration of a firm's sales (data12) across its business segments. $H H I$ is the natural logarithm of the Herfindahl-Hirschman Index of sales concentration in the firm's three-digit SIC industry. Sales Beta is the slope from the time-series regression of annual changes in log industry net sales (using quarterly three-digit SIC code level data) on log GDP growth over the same period. Nasdaq is a dummy variable that equals one if the firm trades on Nasdaq, and zero otherwise. Sales Growth is the annual change in the natural logarithm of sales. Productivity is defined as the ratio of sales over total assets. To estimate the association between the quality of employee relations and the risk measures, we run pooled OLS tests with year and industry fixed effects.

Table 2.11 shows that the coefficients for the control variables are generally significant and carry their expected signs across all models. Moreover, the factor loadings on the Union control variable are negative and significant in the cash flow risk and idiosyncratic risk regressions, which is consistent with earlier predictions by Chen et al. (2008a) and Faleye et al. (2006).

The effect of ERI on cash flow volatility is negative as expected, but not statistically significant. When we consider market-based risk measures, we find that the ERI coefficient primarily relates to idiosyncratic equity risk. The corresponding negative coefficient implies that stronger employee relations reduce the uncertainty about expected cash flows, which is associated with a firm's idiosyncratic risk (Grinblatt and Titman, 1998). We note that when standard errors are clustered at the SIC or CIC industry level (not reported here), we obtain a

\footnotetext{
${ }^{8}$ Data on our measure of cash flow risk are only available for 942 of the sampled firms.
} 


\section{TABLE 2.11}

\section{Cash flow and equity risk analysis}

This table reports pooled OLS regression results for the link between the employee relation index (ERI) and measures for the firm's cash flow and equity risk. We define Cash Flow Risk as the standard deviation of ROA over the previous 15 quarterly observations. Total Equity Risk is the annual standard deviation of daily stock returns. Systematic Risk is the factor loading derived from a regression of a firm's stock returns on the returns of the CRSP value-weighted U.S. stock portfolio, using daily returns over the previous 60 months. Idiosyncratic Risk is the standard deviation of residuals from the preceding regression. Union is defined as the percentage of workers covered by unions in a firm's CIC industry, Leverage as the ratio of total liabilities to total assets, Size as the natural logarithm of total assets, Profit as operating income divided by total assets, and Total payout as dividends plus repurchases divided by total assets. Invest is the natural logarithm of capital expenditure divided by net property, plant, and equipment. Business Concentration is the natural logarithm of a Herfindahl Index measuring the concentration of a firm's sales across its business segments. HHI is the natural logarithm of the HerfindahlHirschman Index of sales concentration in the firm's three-digit SIC industry. Sales Beta is the cyclicality of revenues in the firm's three-digit SIC industry, using quarterly data as slope from the full-sample time-series regression of changes in log industry net sales over the one-year period on log GDP growth over the same period. Nasdaq is a dummy variable that equals one if the firm trades on Nasdaq, and zero otherwise. Sales Growth is the annual change in the natural logarithm of sales. Productivity is defined as the ratio of sales over total assets.

\begin{tabular}{|c|c|c|c|c|}
\hline & Cash Flow Risk & Total Risk & Idiosyncratic Risk & Systematic Risk \\
\hline ERI & $\begin{array}{l}-0.0006 \\
(-1.50)\end{array}$ & $\begin{array}{l}0.0001 \\
(0.48)\end{array}$ & $\begin{array}{l}-0.1001^{*} \\
(-1.73)\end{array}$ & $\begin{array}{l}0.0133 \\
(1.43)\end{array}$ \\
\hline Union & $\begin{array}{l}-0.0001 * \\
(-1.85)\end{array}$ & $\begin{array}{l}0.0000 \\
(-0.93)\end{array}$ & $\begin{array}{l}-0.0269 * * * \\
(-3.76)\end{array}$ & $\begin{array}{l}0.0007 \\
(0.49)\end{array}$ \\
\hline Size & $\begin{array}{l}-0.0020 * * * \\
(-4.63)\end{array}$ & $\begin{array}{l}-0.0011 * * * \\
(-6.86)\end{array}$ & $\begin{array}{l}-0.6560 * * * \\
(-7.77)\end{array}$ & $\begin{array}{l}-0.0017 \\
(-0.12)\end{array}$ \\
\hline Tobin’s Q & $\begin{array}{l}0.0071 * * * \\
(4.07)\end{array}$ & $\begin{array}{l}0.0009 \\
(1.35)\end{array}$ & $\begin{array}{l}0.3592 \\
(1.13)\end{array}$ & $\begin{array}{l}0.2077 * * * \\
(3.72)\end{array}$ \\
\hline Leverage & $\begin{array}{l}0.0152 * * * \\
(3.07)\end{array}$ & $\begin{array}{l}0.0059 * * * \\
(4.50)\end{array}$ & $\begin{array}{l}3.7964 * * * \\
(5.33)\end{array}$ & $\begin{array}{l}0.1320 \\
(1.06)\end{array}$ \\
\hline Profit & $\begin{array}{l}-0.0286^{* *} \\
(-2.05)\end{array}$ & $\begin{array}{l}-0.0186 * * * \\
(-3.72)\end{array}$ & $\begin{array}{l}-5.2648 * * \\
(-2.46)\end{array}$ & $\begin{array}{l}-1.6786 * * * \\
(-4.36)\end{array}$ \\
\hline Total Payout & $\begin{array}{l}0.0039 \\
(0.54)\end{array}$ & $\begin{array}{l}-0.0119 * * * \\
(-3.52)\end{array}$ & $\begin{array}{l}-6.2566 * * * \\
(-3.95)\end{array}$ & $\begin{array}{l}-0.6241 * * \\
(-2.30)\end{array}$ \\
\hline Invest & $\begin{array}{l}0.0016^{*} \\
(1.91)\end{array}$ & $\begin{array}{l}0.0009 * * * \\
(2.62)\end{array}$ & $\begin{array}{l}0.2120 \\
(1.07)\end{array}$ & $\begin{array}{l}0.0815^{* * * *} \\
(2.66)\end{array}$ \\
\hline Business Concentration & $\begin{array}{l}-0.0004 \\
(-0.63)\end{array}$ & $\begin{array}{l}0.0007 * * * \\
(2.64)\end{array}$ & $\begin{array}{l}0.3964 * * * \\
(2.91)\end{array}$ & $\begin{array}{l}0.0037 \\
(0.17)\end{array}$ \\
\hline HHI & $\begin{array}{l}-0.0013^{* *} \\
(-2.02)\end{array}$ & $\begin{array}{l}-0.0001 \\
(-0.44)\end{array}$ & $\begin{array}{l}-0.0712 \\
(-0.48)\end{array}$ & $\begin{array}{l}0.0070 \\
(0.29)\end{array}$ \\
\hline Sales Beta & $\begin{array}{l}0.0000 \\
(0.04)\end{array}$ & $\begin{array}{l}0.0000 \\
(0.10)\end{array}$ & $\begin{array}{l}0.0103 \\
(0.51)\end{array}$ & $\begin{array}{l}0.0092 * * * \\
(2.66)\end{array}$ \\
\hline Nasdaq & $\begin{array}{l}0.0068 * * * \\
(3.68)\end{array}$ & $\begin{array}{l}0.0057 * * * \\
(8.28)\end{array}$ & $\begin{array}{l}2.8698 * * * \\
(7.98)\end{array}$ & $\begin{array}{l}0.3236^{* * * *} \\
(5.20)\end{array}$ \\
\hline Sales Growth & $\begin{array}{l}0.0003 \\
(0.36)\end{array}$ & $\begin{array}{l}0.0002 \\
(0.73)\end{array}$ & $\begin{array}{l}0.2444 * \\
(1.90)\end{array}$ & $\begin{array}{l}0.0147 \\
(0.72)\end{array}$ \\
\hline Productivity & $\begin{array}{l}0.0010 \\
(1.07)\end{array}$ & $\begin{array}{l}0.0008 * * \\
(2.04)\end{array}$ & $\begin{array}{l}0.3942 * \\
(1.91)\end{array}$ & $\begin{array}{l}-0.0080 \\
(-0.25)\end{array}$ \\
\hline Year Fixed Effects & Yes & Yes & Yes & Yes \\
\hline Industry Fixed Effects & Yes & Yes & Yes & Yes \\
\hline Adjusted $\mathrm{R}^{2}$ & 0.10 & 0.41 & 0.40 & 0.22 \\
\hline \# Observations & 4,536 & 4,705 & 4,705 & 4,705 \\
\hline
\end{tabular}

$* * * \mathrm{p}<0.01, * * \mathrm{p}<0.05, * \mathrm{p}<0.1$

Robust t-statistics in parentheses. Standard errors are heteroskedasticity robust and clustered at the firm. 
significantly negative coefficient on ERI in both the cash flow risk and idiosyncratic risk regression. The relation between $E R I$ and, respectively, total equity risk as well as systematic risk remains statistically insignificant.

These results are consistent with our conjecture that stronger employee relations reduce firm specific risks. Finding that ERI relates negatively to firm-specific equity risk is consistent with the view that better employee relations mitigate litigation and reputational risks, among other, because these types of risk are known to affect idiosyncratic volatility. In turn, idiosyncratic volatility has been associated positively with the yield spread on corporate bonds by Campbell and Taksler (2003). Building on Merton's (1974) bond pricing framework, the authors confirm that higher equity volatility increases the firm's likelihood of reaching the boundary condition for default, and that informed investors in turn require a higher yield spread (see also, Jones et al., 1984). Campbell and Taksler (2003) also point out that this condition holds if default risk is idiosyncratic, and that the effect of volatility on bond spreads alters the expected payoffs on corporate debt, even if it does not influence the expected return or risk premium on debt.

\subsection{Conclusion}

This study provides comprehensive evidence that human capital management affects a firm's credit risk. We develop a measure for the quality of employee relations for a large cross-section of U.S. firms, and find that firms with stronger employee relations have a lower cost of debt financing, higher credit ratings, and lower firm-specific risk. These findings are robust to a host of control variables and alternative model specifications. Our results support the theory that adequate management of employee relations improves the firm's credit standing by reducing various firm-specific risks that affect the level and stability of expected cash flows, and which cannot easily be diversified away by bondholders.

The results of this chapter have important practical implications. Information about the quality of employee relations is not easily obtained without consulting costly external research providers. The ability of employment policies and practices to explain variations in credit risk, makes a case for rethinking current corporate disclosure practices and accounting conventions, which still pay limited attention to stakeholder relations. Given the major role of debt as a source of capital for businesses, we conclude that firms benefit from doing a better job of disclosing their employment practices to bondholders, since doing so helps to attract capital at more favorable rates. 


\section{A Appendix}

\section{TABLE 2.A1}

\section{Recoding credit rating classifications}

We standardize the multiple bond and issuer rating classifications according to the rating schedule presented in Panel A. We base Bond Ratings on equally weighted Moody's and S\&P bond issue ratings collected from Mergent FISD (Columns 1-2), and Issuer Ratings on S\&P's long-term domestic issuer ratings as compiled by Compustat (Column 3). Column 4 lists the S\&P and Moody's ratings, which we collapse into seven categories ranging from one (lowest creditworthiness) to seven (highest credit-worthiness). This approach follows Ashbaugh-Skaife et al. (2006). Debt to which we assign a rating category of one to three (i.e. below BBB-) constitutes speculative grade debt, and that between four and seven represents investment grade debt. Panel B presents summary statistics of the recoded Bond Rating and Issuer Rating distributions.

\begin{tabular}{|c|c|c|c|c|c|c|}
\hline \multicolumn{7}{|c|}{ PANEL A: Recoding schedule for rating categories } \\
\hline Moody's Rating & $S \& P$ Rating & $\begin{array}{l}\text { Compustat } \\
\text { (data280) }\end{array}$ & & $\begin{array}{l}\text { Assigned } \\
\text { Rating Code }\end{array}$ & & Rating Grade \\
\hline Ааa & AAA & 2 & & 7 & & Investment \\
\hline Aa1 & $\mathrm{AA}+$ & 4 & & 6 & & Investment \\
\hline $\mathrm{Aa} 2$ & AA & 5 & & 6 & & Investment \\
\hline Aa3 & AA- & 6 & & 6 & & Investment \\
\hline $\mathrm{A} 1$ & $A+$ & 7 & & 5 & & Investment \\
\hline $\mathrm{A} 2$ & A & 8 & & 5 & & Investment \\
\hline $\mathrm{A} 3$ & A- & 9 & & 5 & & Investment \\
\hline Baa1 & $\mathrm{BBB}+$ & 10 & & 4 & & Investment \\
\hline Baa2 & BBB & 11 & & 4 & & Investment \\
\hline Baa3 & BBB- & 12 & & 4 & & Investment \\
\hline B1 & $\mathrm{BB}+$ & 13 & & 3 & & Speculative \\
\hline B2 & $\mathrm{BB}$ & 14 & & 3 & & Speculative \\
\hline B3 & BB- & 15 & & 3 & & Speculative \\
\hline $\mathrm{B}$ & $\mathrm{B}+$ & 16 & & 2 & & Speculative \\
\hline B2 & B & 17 & & 2 & & Speculative \\
\hline B3 & B- & 18 & & 2 & & Speculative \\
\hline Caa1 & $\mathrm{CCC}+$ & 19 & & 1 & & Speculative \\
\hline $\mathrm{Caa} 2$ & $\mathrm{CCC}$ & 20 & & 1 & & Speculative \\
\hline Caa3 & CCC- & 21 & & 1 & & Speculative \\
\hline $\mathrm{Ca}$ & $\mathrm{CC}$ & 23 & & 1 & & Speculative \\
\hline $\mathrm{C}$ & $\mathrm{D}, \mathrm{SD}$ & 27,29 & & 1 & & Speculative \\
\hline \multicolumn{7}{|c|}{ PANEL B: Distributions of bond and issuer ratings } \\
\hline \multirow{2}{*}{\multicolumn{2}{|c|}{$\begin{array}{l}\text { Assigned } \\
\text { Rating Category }\end{array}$}} & \multicolumn{2}{|c|}{ Bond Rating } & & \multicolumn{2}{|c|}{ Issuer Rating } \\
\hline & & Freq. & $\%$ & & Freq. & $\%$ \\
\hline 7 (AAA) & & 32 & 1.41 & & 42 & 0.75 \\
\hline $6(\mathrm{AA}+$ to $\mathrm{AA}-)$ & & 189 & 8.34 & & 943 & 16.94 \\
\hline $5(\mathrm{~A}+$ to $\mathrm{A}-)$ & & 826 & 36.47 & & 1,495 & 26.85 \\
\hline $4(\mathrm{BBB}+$ to $\mathrm{BBB}-)$ & & 916 & 40.44 & & 1,624 & 29.17 \\
\hline $3(\mathrm{BB}+$ to $\mathrm{BB}-)$ & & 229 & 10.11 & & 1,223 & 21.96 \\
\hline $2(\mathrm{~B}+$ to $\mathrm{B}-)$ & & 63 & 2.78 & & 181 & 3.25 \\
\hline $1(\mathrm{CCC}+$ to $\mathrm{D})$ & & 10 & 0.44 & & 60 & 1.08 \\
\hline Total & & 2,265 & 100 & & 5,568 & 100 \\
\hline
\end{tabular}


TABLE 2.A2

\section{Variable definitions and predicted relations}

This table describes the test and control variables of the analysis. Column 1 reports the variable categories, names, and data sources. Column 2 lists their predicted relation with the dependent variables, the cost of debt (Spread) and credit ratings (Bond Rating, Issuer Rating), respectively. Column 3 provides variable definitions, and Column 4 denotes the data items or categories used within each data source.

\begin{tabular}{|c|c|c|c|}
\hline Variables & $\begin{array}{l}\text { Predicted Sign } \\
\text { Spread/Ratings }\end{array}$ & Definition & Data Items \\
\hline \multicolumn{4}{|c|}{ Employee Relations Index (Source: KLD Stats) } \\
\hline ERI & $-1+$ & $\begin{array}{l}\text { Performance strength indicators - } \\
\text { Performance concern indicators }\end{array}$ & $\begin{array}{l}\text { Employee Relations, } \\
\text { Diversity }\end{array}$ \\
\hline \multicolumn{4}{|c|}{ Credit issuer specific controls (Source: Compustat North America) } \\
\hline Leverage & $+/-$ & Total liabilities / Total assets & $($ data181/data6)*100 \\
\hline Size & $-1+$ & Natural logarithm of total assets. & $\ln ($ data6) \\
\hline Capital Intensity & $-1+$ & Gross property, plant \& equipment / Total assets & $($ data7/data6)*100 \\
\hline Interest Coverage & $-1+$ & $\begin{array}{l}\text { Operating income before depreciation / } \\
\text { Interest expense }\end{array}$ & data $13 /($ data 15 or data339) \\
\hline Return on Assets & $-1+$ & Income before extraordinary items / Total assets & $($ data18/data6)*100 \\
\hline Loss & $+1-$ & $\begin{array}{l}\text { Equal to one if the net income before extraordinary } \\
\text { items is negative in current and prior fiscal year, } \\
\text { otherwise zero. }\end{array}$ & data18 \\
\hline Financial & $-1+$ & $\begin{array}{l}\text { Equal to one if firm classifies as financial firm, } \\
\text { otherwise zero. }\end{array}$ & one-digit SIC $=6$ \\
\hline Utility & $-1+$ & $\begin{array}{l}\text { Equal to one if firm classifies as utility, otherwise } \\
\text { zero. }\end{array}$ & two-digit SIC $=49$ \\
\hline \multicolumn{4}{|c|}{ Credit issue specific controls (Source: Mergent FISD) } \\
\hline TTM & $+1-$ & $\begin{array}{l}\text { Time-to-maturity, the time until expiration of the } \\
\text { bond contract. }\end{array}$ & offering_date ; maturity \\
\hline Issue Size & $?$ & $\begin{array}{l}\text { Natural logarithm of the par value of debt originally } \\
\text { issued. }\end{array}$ & offering_amt \\
\hline Subordinated & $+1-$ & $\begin{array}{l}\text { Equal to one if bond issue classifies as senior- } \\
\text { subordinated, otherwise zero. }\end{array}$ & security_level \\
\hline Speculative & $+1-$ & $\begin{array}{l}\text { Equal to one if firm has subordinated debt, otherwise } \\
\text { zero. }\end{array}$ & Rating \\
\hline \multicolumn{4}{|c|}{ Additional controls (Source: RiskMetrics; Union Membership and Coverage Database) } \\
\hline Gindex & $-1+$ & $\begin{array}{l}\text { Measure of the number of governance provisions } \\
\text { that limit the rights of the firm's shareholders } \\
\text { (Gompers, Ishii, and Metrick, 2003). }\end{array}$ & Governance Index \\
\hline Union & $-1+$ & $\begin{array}{l}\text { Percentage of workers in a CIC industry, who are } \\
\text { covered by unions in their collective bargaining. }\end{array}$ & $\% \operatorname{Cov}$ \\
\hline
\end{tabular}


FIGURE 2.A1

Distribution of the Employee Relations Index (ERI)

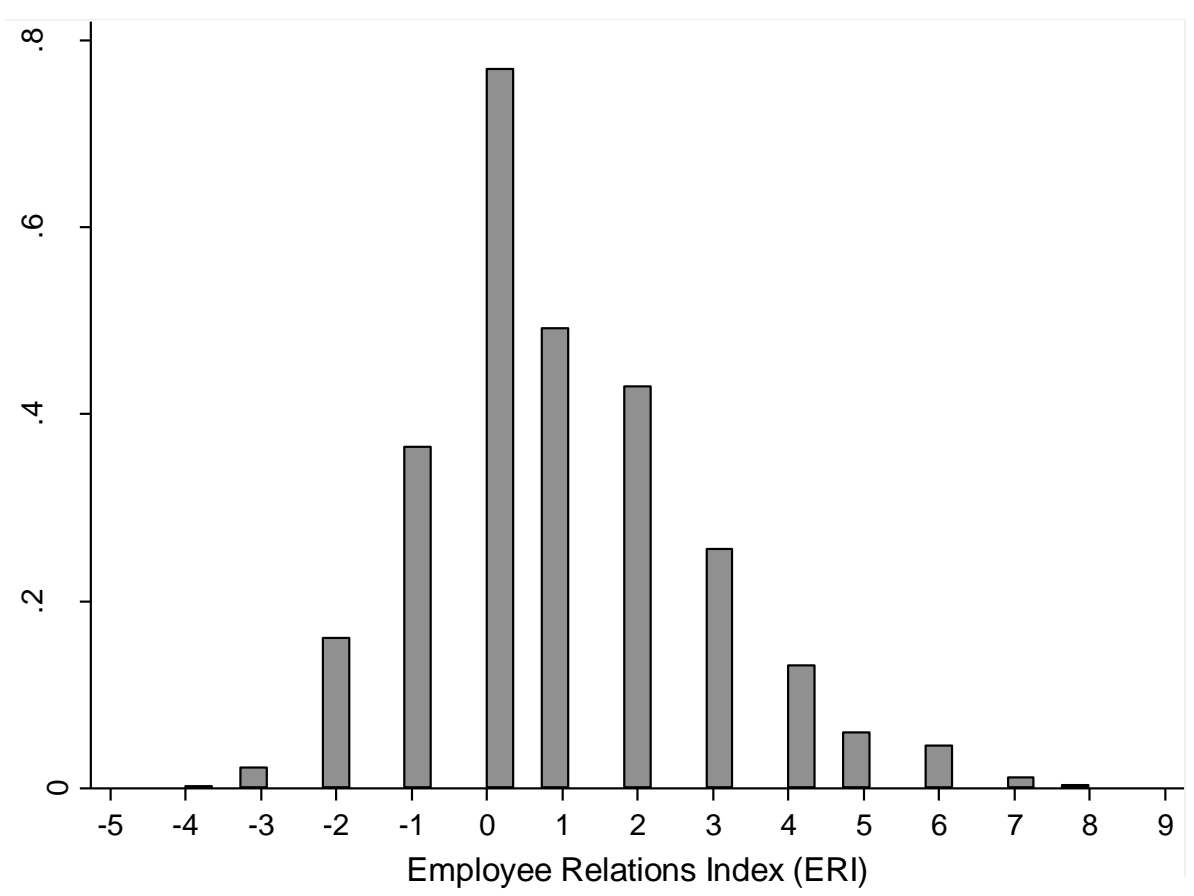




\section{TABLE 2.A3}

\section{Correlation matrix}

This table provides the correlation statistics for the model variables. The lower left-hand part of the matrix reports pairwise Pearson product-moment correlations, while the upper right-hand part reports Spearman rank-order correlations. Coefficients at or below the $1 \%$ significance level are printed in bold.

\begin{tabular}{|c|c|c|c|c|c|c|c|c|c|c|c|c|c|c|c|c|c|c|}
\hline & & $\mathbf{A}$ & B & $\mathbf{C}$ & D & $\mathbf{E}$ & $\mathbf{F}$ & $\mathbf{G}$ & $\mathbf{H}$ & I & $\mathbf{J}$ & $\mathbf{K}$ & $\mathbf{L}$ & $\mathbf{M}$ & $\mathbf{N}$ & $\mathbf{O}$ & $\mathbf{P}$ & $\mathbf{Q}$ \\
\hline (A) & ERI & & -0.22 & 0.34 & 0.05 & 0.34 & -0.07 & 0.18 & 0.12 & -0.03 & 0.12 & 0.04 & -0.02 & 0.23 & 0.00 & -0.16 & -0.15 & 0.03 \\
\hline (B) & $\ln ($ Spread $)$ & -0.24 & & -0.63 & 0.21 & -0.20 & 0.01 & -0.51 & -0.38 & 0.20 & -0.08 & 0.14 & 0.08 & 0.05 & 0.08 & 0.47 & -0.01 & 0.06 \\
\hline (C) & Bond Rating & 0.35 & -0.65 & & -0.11 & 0.26 & -0.07 & 0.47 & 0.35 & -0.17 & 0.18 & -0.10 & 0.05 & 0.03 & -0.06 & -0.64 & -0.16 & -0.02 \\
\hline (D) & Leverage & 0.03 & 0.22 & -0.15 & & 0.23 & -0.04 & -0.41 & -0.41 & 0.12 & 0.26 & 0.17 & 0.03 & 0.11 & 0.14 & 0.14 & 0.01 & -0.04 \\
\hline (E) & Size & 0.35 & -0.22 & 0.32 & 0.24 & & -0.17 & 0.01 & -0.18 & -0.04 & 0.34 & -0.01 & 0.05 & 0.58 & 0.04 & -0.18 & -0.10 & -0.14 \\
\hline$(\mathrm{F})$ & Capital Intensity & -0.11 & 0.02 & -0.07 & -0.02 & -0.23 & & -0.10 & 0.11 & 0.02 & -0.56 & 0.29 & 0.11 & -0.15 & -0.14 & 0.02 & 0.38 & 0.04 \\
\hline (G) & Interest Coverage & 0.22 & -0.41 & 0.40 & -0.33 & 0.06 & -0.17 & & 0.66 & -0.22 & 0.13 & -0.30 & 0.05 & -0.03 & -0.21 & -0.33 & -0.16 & -0.04 \\
\hline (H) & ROA & 0.11 & -0.40 & 0.36 & -0.35 & -0.14 & 0.07 & 0.51 & & -0.26 & -0.21 & -0.24 & 0.07 & -0.11 & -0.14 & -0.18 & -0.05 & -0.04 \\
\hline (I) & Loss & 0.01 & 0.25 & -0.21 & 0.12 & -0.04 & 0.02 & -0.13 & -0.34 & & -0.04 & -0.05 & -0.06 & 0.03 & 0.04 & 0.23 & -0.01 & -0.07 \\
\hline$(\mathrm{J})$ & Financial & 0.09 & -0.06 & 0.17 & 0.27 & 0.42 & -0.54 & 0.12 & -0.16 & -0.04 & & -0.12 & 0.03 & 0.11 & 0.16 & -0.14 & -0.37 & -0.01 \\
\hline$(\mathrm{K})$ & Utility & 0.00 & 0.13 & -0.06 & 0.14 & -0.04 & 0.29 & -0.20 & -0.22 & -0.05 & -0.12 & & -0.09 & 0.01 & -0.04 & -0.05 & -0.03 & 0.03 \\
\hline (L) & TTM & 0.00 & 0.03 & 0.13 & 0.00 & 0.03 & 0.11 & -0.01 & 0.07 & -0.08 & 0.01 & -0.04 & & -0.05 & 0.02 & -0.04 & 0.11 & 0.05 \\
\hline (M) & Issue Size & 0.26 & 0.01 & 0.05 & 0.03 & 0.47 & -0.13 & 0.13 & -0.04 & 0.00 & 0.03 & -0.01 & -0.05 & & 0.07 & 0.03 & -0.16 & -0.09 \\
\hline$(\mathrm{N})$ & Subordinate & -0.02 & 0.10 & -0.14 & 0.11 & 0.09 & -0.13 & -0.11 & -0.09 & 0.03 & 0.13 & -0.05 & -0.04 & 0.06 & & 0.13 & -0.10 & 0.00 \\
\hline$(\mathrm{O})$ & Speculative & -0.16 & 0.48 & -0.69 & 0.15 & -0.18 & 0.04 & -0.24 & -0.19 & 0.22 & -0.14 & -0.06 & -0.12 & 0.03 & 0.16 & & 0.11 & -0.12 \\
\hline (P) & Union & -0.17 & 0.02 & -0.14 & 0.05 & -0.04 & 0.45 & -0.24 & -0.11 & -0.03 & -0.29 & 0.08 & 0.09 & -0.11 & -0.08 & 0.03 & & 0.08 \\
\hline (Q) & Gindex & -0.03 & 0.06 & 0.00 & -0.05 & -0.15 & 0.06 & -0.10 & -0.04 & -0.06 & -0.03 & 0.04 & 0.06 & -0.08 & -0.01 & -0.12 & 0.06 & \\
\hline
\end{tabular}





\title{
Chapter 3
}

\section{Corporate Environmental Management and Credit Risk*}

\begin{abstract}
This chapter examines whether corporate environmental management has credit risk implications for bond investors. I present evidence supporting the view that the credit standing of borrowing firms is influenced by legal, reputational, and regulatory risks associated with environmental incidents. Using information on the environmental profile of 582 U.S. public corporations between 1995 and 2006, I document that (i) environmental concerns are associated with a higher cost of debt financing and lower credit ratings, and (ii) proactive environmental practices are associated with a lower cost of debt. The results are robust to numerous controls for company and bond specific characteristics, alternative model specifications, and industry membership.
\end{abstract}

\subsection{Introduction}

The environmental impact of businesses has been the subject of public debates ever since corporate negligence repeatedly results in incidents with immense damage caused to the environment and human health (e.g., the Seveso incident in 1976; Bhopal incident in 1984; Exxon Valdez oil spill in 1985; Brent Spar incident in 1995; and the Great Barrier Reef collision of the freighter Sheng Neng 1 as well as Deepwater Horizon oil spill in 2010). In the wake of growing climate change concerns and recent environmental disasters, the matter is gaining unprecedented public attention and fuels the ongoing controversy over the social responsibility of firms and the role of governments in regulating corporate behavior. With calls for stricter environmental regulations growing louder, financial markets are wary of the often uncertain financial implications that arise from such regulatory interventions. To better evaluate their exposure to environmental risks, investors therefore increasingly demand that firms assess and disclose their management of environmental issues.

In this chapter, we investigate the credit risk implications of corporate environmental management for bond investors. Our conceptual framework is based on the view that environmental practices influence the solvency of borrowing firms by determining their exposure to legal, reputational, and regulatory risks. Firms that engage in environmental

\footnotetext{
* This chapter is based on Bauer and Hann (2011), which was presented at the 2010 SRI in Rockies Conference (San Antonio, USA). I thank the Haas School of Business, University of California at Berkeley and Social Investment Forum for awarding this study the 2010 Moskowitz Prize for Best Paper in Socially Responsible Investing. I am also grateful for the financial support provided by the Swedish foundation for strategic environmental research (MISTRA).
} 
misconduct can incur costly penalties and evoke strong negative reactions from both financial and non-financial stakeholders, each of which affect their default risk and thus impair the value of their fixed income securities. The Deepwater Horizon oil spill in the Gulf of Mexico illustrates the tremendous negative impact that environmental incidents can have on the credit standing of firms. ${ }^{9}$ Bond investors who want to protect themselves against environmental performance related losses require a better understanding of how the different corporate environmental activities relate to credit risk, before making their decision to lend. This study aims to provide a better insight into this issue.

To test the hypothesized relation, our analysis takes advantage of the growing coverage and popularity of independent rating agencies that specialize in the evaluation of corporate environmental performance (e.g., Luck and Pilotte, 1993; Derwall, Guenster, Bauer, and Koedijk, 2005; Fisman, Heal, and Nair, 2006; Kempf and Osthoff, 2007; Statman and Glushkov, 2009). These widely used performance ratings typically combine a range of public and proprietary information to provide a comprehensive overview on the environmental management of firms. We collect data on a range of corporate environmental activities to construct aggregate measures of the firm's environmental strengths and concerns, and subsequently regress the cost of debt and credit ratings on these measures.

The results presented herein are consistent with the prediction that the environmental management of firms has wealth implications for bond investors. We report economically meaningful and statistically significant relations between the environmental performance measures and both the cost of debt and credit ratings of borrowing firms. The corporate activities underlying the documented relations are mainly attributable to regulatory and climate change issues, but also to efforts to reduce environmental risk exposure, and to enhance cash flows by supplying innovative products and services with environmental benefits. We estimate a maximum environmental performance effect on the cost of debt of up to 64 basis points per annum. Our analysis provides no evidence that the impact of environmental management is consistently higher or restricted to firms in high risk industries, but rather suggests that it is important to account for the heterogeneity across these industries. Finally, we show that the relevance of environmental management issues has increased for bond investors over the recent decade, consistent with the view that widespread climate change concerns have heightened investors' awareness of potential regulatory changes and other associated financial risks.

Our study adds to the literature by providing comprehensive evidence that corporate environmental management is a cross-sectional determinant in the valuation of credit risk. We follow up on earlier work that reports on a credit risk effect for misreported environmental liabilities (Graham, Maher, and Northcut, 2001; Graham and Maher, 2006), and show that the environmental practices of firms are reflected in the pricing of newly issued bonds in anticipation of the associated risks. Unlike similar studies that exclusively focus on environmental concerns (Schneider, 2010; Sharfman and Fernando, 2008), this study is the first to also consider corporate activities that are directed at reducing environmental risk exposure or enhancing cash flows. Furthermore, it is the first study to investigate the hypothesized relations in a comprehensive sample across multiple industries. Finally, our work complements earlier

\footnotetext{
${ }^{9}$ In April 2010, an explosion on the Deepwater Horizon drilling rig resulted in the largest offshore oil spill in U.S. history. Following this incident, BP p.l.c., which was named the responsible party by the U.S. Government, experienced a significant deterioration of its financial condition. The firm's stock price dropped from $\$ 60.48$ to as low as $\$ 26.75$, while its credit ratings were downgraded from AA to BBB and its credit default spread soared from 44 bps up to 600 bps.
} 
credit risk research on lender liability (e.g., Pitchford, 1995, 2001; Boyer and Laffont, 1995, 1997; Heyes, 1996; Balkenborg, 2001; Kroszner and Strahan, 2001), by demonstrating that environmental concerns do not only constitute a meaningful risk for bank lenders (see Chava, 2010), but also for investors in non-secured publicly traded debt. Our analysis contributes to an enhanced understanding of how environmental performance aspects influence the pricing of credit risk, and provides better guidance to risk managers on where to direct their attention to.

The chapter is organized as follows. Section 2 introduces the conceptual framework for our analysis. We discuss environmental management as a potential source of risk for bond investors, and contrast our work with earlier research. Section 3 formulates testable hypotheses for the relation between environmental management and credit risk. Section 4 describes the sample selection and data sources, define the variables, and provide descriptive statistics. Section 5 presents our results and corresponding robustness tests. Section 6 concludes this study.

\subsection{Conceptual Framework and Related Literature}

\subsubsection{Environmental management and bondholder risk}

Bond investors primarily need to concern themselves with the environmental management of borrowing firms, because of the potential liabilities that arise for businesses under the U.S. legal and regulatory framework. Firms that are held responsible for environmental violations can incur substantial clean-up costs, fines, and damage awards. These environmental liabilities do not only burden the solvency of borrowers, but according to environmental law also often subordinate the claims of their debt holders. Furthermore, if these liabilities pose a significant risk to the firm's financial viability, management can be tempted to file for strategic bankruptcy in an attempt to avoid them. ${ }^{10}$ Given that an inadequate management of environmental risks increases the likelihood of costly future liabilities, bondholders should expect a higher default risk for borrowers with poor environmental practices, and a consequently impaired value of their investments.

The potentially far-reaching legal consequences of poor environmental management are best illustrated through the Comprehensive Environmental Response, Compensation, and Liability Act (CERCLA). ${ }^{11}$ Commonly known as Superfund, this federal law gives the Environmental Protection Agency (EPA) the authority to identify parties responsible for the pollution of sites, and compel them to bear the costs and responsibility for remediating contaminations. ${ }^{12}$ Environmental liabilities imposed under CERCLA are retroactive, joint and several, and strict. That is, (i) parties can be held liable for incidents that occurred before the enactment of CERCLA in 1980; (ii) if the damage is caused by multiple parties but cannot be

\footnotetext{
${ }^{10}$ Filing a petition for bankruptcy under Chapter 11 enables firms to reorganize their business by preventing the complete liquidation of their assets, and discharging many of their pre-petition debts. Environmental violators can attempt to exploit the existing legal ambiguity on whether environmental liabilities constitute dischargeable claims or not, in order to avoid them (e.g., Greenberg and Shaw, 1991; Kishiyama, 2003).

${ }^{11}$ Other environmental laws that generate potential liabilities for businesses include the Clean Air Act; Clean Water Act; Emergency Protection and the Community Right-to-Know Act; Federal Insecticide, Fungicide, and Rodenticide Act; Marine Protection, Research, and Sanctuaries Act; Pollution Prevention Act; Resource Conservation and Recovery Act; Safe Drinking Water Act; and the Toxic Substance Control Act.

${ }^{12}$ www.epa.gov/superfund
} 
separated, any single party may be held liable for the entire cleanup; (iii) and no negligence is required to be held liable, only involvement at the site (e.g., as generator, transporter, operator, or owner). Moreover, if a responsible firm merges or is acquired, its environmental liabilities are generally not discharged, but carried over to the new entity.

Allegations or charges of environmental violations also have economic implications that extend beyond the direct costs of litigation. Stakeholders who take issue with socially questionable practices or fear reputational risks from being associated with an environmental scandal are likely to restrict or dissolve their relationship with the firm. A deterioration of key stakeholder relationships in turn affects the level and volatility of cash flows, which influences firm value and raises the default risk of borrowers. For example, Konar and Cohen (2001) report that the size of legally emitted toxic chemicals is negatively correlated with the intangible asset value of the firm. In addition, environmental offenders can experience difficulties in attaining cost-efficient funding as well as a reduction in the liquidity of their securities. Particularly banks are cautious about financing firms with poor environmental practices because - next to the risk of incurring reputation and repayment losses (McKenzie and Wolfe, 2004) - a too close involvement with such clients can make them liable for environmental obligations (e.g., Pitchford, 1995, 2001; Boyer and Laffont, 1995, 1997; Heyes, 1996; Balkenborg, 2001; Kroszner and Strahan, 2001). ${ }^{13}$ Adding to these liquidity constraints are increasing public demands to limit or shun investments in firms with socially irresponsible practices, which leads institutional investors to gradually adopt environmental performance screens for their portfolios. The reluctance of investors to finance or hold securities of environmental offenders can thus require an additional risk and liquidity premium on the cost of capital for firms with questionable practices (e.g., Garber and Hammitt, 1998).

While the current environmental laws and regulations address a wide range of corporate activities, the risk of regulatory intervention has progressively increased over the recent decades. Primary drivers of this development are the growing concerns about global climate change, and the repeated environmental disasters in which corporate neglect has resulted in immense environmental damage and social costs. Whereas the climate change debate has sensitized the public to the environmental impact of business, the controversy over stricter regulation has in particular been fuelled by environmental incidents that expose the inability of governments to effectively hold environmental offenders liable for the damage that they cause (see, e.g., Exxon Valdez spill in 1985; Deepwater Horizon oil spill in 2010).

In view of the persistent media coverage and public pressure on policy makers to implement environmental reforms, state and federal governments are expected to eventually respond by more rigorously enforcing existing environmental regulations, imposing more stringent regulations, and introducing more severe criminal and civil penalties for polluters. Although such a tightening of regulations typically targets firms in high-risk industries, borrowers in seemingly low-risk industries can increasingly constitute a credit risk as well, if they fail to recognize and manage the very environmental risks that they are exposed to. The higher compliance costs and tighter oversight that accompany stricter regulations represent an

\footnotetext{
${ }^{13}$ Following the CERCLA Amendments in 1996, banks are liable as 'owners or operators' of a polluted site, if their participation in management can be established (see, e.g., New York vs. HSBC USA, N.A.). Although generally protected under the secured creditor exemption rule, a number of situations exist that continue to expose banks to lender liability (Ahrens and Langer, 2008). Bondholders, unlike banks, cannot be held directly responsible for the environmental liabilities of their borrowers. Our focus on unsecured publicly traded debt therefore makes lender liability only indirectly relevant to this study.
} 
additional drain on cash flows, which can pose a significant burden for firms that operate at minimal compliance standards. Altogether, the relevance of environmental management as a means to protect firms and their investors against legal, reputational, and regulatory risks is likely to increase over time and across industries.

\subsubsection{Related literature}

Prior research suggests that the credit market accounts for the impact of environmental liabilities on the solvency of borrowers. Graham, Maher, and Northcut (2001) report that a firm's listing as potentially responsible party for Superfund liabilities is associated with a significant deterioration of its bond ratings. Graham and Maher (2006) confirm and extend this finding, by showing that bond ratings and bond yields are both significantly related to the number of times that a firm is named a potentially responsible party. A commonality in these studies is that they are motivated by the potential misreporting of existing Superfund liabilities: According to the environmental accounting literature, financial statements do not accurately reflect the firm's past or present environmental liabilities under the prevailing accounting standards and practices (Barth and McNichols, 1994; Gamble, Hsu, Kite, and Radtke, 1995; Barth, McNichols, and Wilson, 1997; Blacconiere and Northcut, 1997; Graham et al. 2001). Schneider (2010) discusses these accounting regulations in detail, and points to the considerable discretion that firms are granted in their reporting of environmental liabilities. ${ }^{14}$ The resulting understatement or omission of environmental liabilities is particularly problematic for lenders, because when these obligations are finally realized, their actual values can significantly exceed the ones reported on the balance sheet, and thus cause an adverse shock to debt recovery.

Our study differs from the preceding literature in that we analyze the credit risk relations for a broad range of corporate environmental activities, instead of focusing on the potential misreporting of environmental liabilities after their occurrence. Bond investors who want to protect themselves from environmental performance related losses need to identify and evaluate environmental risks prior to their decision to lend. We aim to contribute to the environmental risk assessment of borrowing firms by providing an improved understanding of the relation between environmental management and credit risk. For this purpose, we test the credit risk implications of a comprehensive set of past and ongoing corporate environmental activities across multiple industries. Next to studying the environmental concerns of firms, this paper is the first to also consider their efforts to reduce environmental risk exposure.

The papers closest to our work are Chava (2010) and Schneider (2010). Chava (2010) studies whether the environmental performance of firms affects the cost of their bank loans. The study documents a significantly negative relation, which is suggested to result from an increase in environmentally responsible lending. Moreover, it provides initial evidence that this relation does not simply capture an omitted component of firm's default risk. Schneider (2010) tests the impact of toxic emission levels on the pricing of bonds for firms in the paper and pulp or chemical industry. The author reports that higher toxic emission levels are associated with

\footnotetext{
${ }^{14}$ More specifically, firms need not recognize a liability in a given period, if it can be argued that a reasonable estimate is not feasible. When the estimation of a liability produces a range of possible outcomes, the most likely amount is recorded. In the case that each of these estimates is equally likely, the firm is permitted to report the lowest amount.
} 
lower bond ratings and a premium on the cost of debt, but that this relation fades with increasing bond quality.

\subsection{Hypotheses Development}

The preceding discussion suggests that environmental performance constitutes a source of credit risk, and that the informed lender tries to anticipate associated losses through a comprehensive assessment of the borrower's environmental management prior to lending. We formally test the credit risk implications of environmental management by relating information on the firm's environmental activities to key measures of its credit standing. While fixedincome investors typically focus on the downside risk of borrowers, they may also benefit from corporate initiatives that prevent environmental incidents or mitigate their consequences. Our analysis therefore distinguishes between corporate activities that increase environmental risks, and those that are directed at reducing environmental risk exposure.

Our first hypothesis regards the link between environmental concerns and credit risk. We argue that firms with poor environmental practices are more likely to default on their debt obligations, because of their higher exposure to potentially costly environmental litigation, reputational losses, and regulatory risk. Consequently, we expect that the credit market requires a compensation for this incremental risk in form of a higher cost of debt, and lower credit ratings to reflect the lower credit standing. We derive the following hypothesis stated in alternative form:

\section{Hypothesis 1: Firms with more environmental concerns have a higher cost of debt financing and lower credit ratings.}

In contrast, a proactive engagement in environmental matters is expected to reduce the likelihood as well as consequences of environmental violations, and can serve as a signal that management is committed to a low-risk environmental strategy. Earlier research also suggests that environmental management can enhance the firm's financial position by reducing costs and increasing profitability. Reinhardt (1999) argues that an engagement beyond compliance standards can improve production efficiency, increase demand from environmentally sensitive consumers, discourage stakeholder activism, and help firms to attract skilled workers. Several studies confirm that strong environmental performance is indeed associated with higher profitability and firm value (e.g., Klassen and McLaughlin, 1996; Russo and Fouts, 1997; Konar and Kohen, 2001; King and Lenox, 2002). Given these positive cash flow implications, we derive the following hypothesis on the effect of environmental engagement on credit risk:

\section{Hypothesis 2: Firms with a more proactive environmental engagement have a lower cost of debt financing and higher credit ratings.}

The preceding hypotheses both implicitly assume that environmental management equally affects the credit standing of firms across different industries. However, since firms that operate in environmentally risky industries are considered more prone to incidents, they should also 
form a more likely credit risk to bond investors. We thus expect that the credit risk implications of environmental management are more significant for firms in inherently risky industries:

\section{Hypothesis 3: The link between environmental performance and credit risk is stronger for firms that operate in environmentally risky industries.}

We argue that corporate environmental management affects credit risk through the associated legal, regulatory, and reputational consequences. An important factor underlying this relation is the general attention that is awarded to environmental issues, because of its role in shaping public opinion and influencing regulatory policy. Although the protection of the natural environment and human health has been an ongoing public concern for decades, it is only since the recent climate change debate that the environmental impact of corporations has gained widespread attention from the media and policy makers. Notable events that fall into our sample period include the third assessment report on climate change by the Intergovernmental Panel on Climate Change (IPCC) in 2001, the coming into effect of the Kyoto Protocol ${ }^{15}$ and initiation of the United Nations Principles for Responsible Investment (UNPRI) in 2005, and the Stern Review on the economics of climate change in 2006. Given this growing awareness of environmental concerns, we hypothesize that the risks associated with corporate environmental violations have increased over time, and with it the relevance of environmental management for bond investors.

\section{Hypothesis 4: The impact of environmental performance on credit risk has increased over the recent decade.}

\subsection{Data}

\subsubsection{Environmental management performance}

We construct measures for the firm's environmental management performance using data from Kinder, Lydenberg, and Domini Research \& Analytics (KLD). KLD is an independent investment research company that specializes in the assessment of firms' environmental management, social performance, corporate governance standards, and product quality. It issues annual performance evaluations based on a wide variety of information, which include external surveys and ratings, corporate websites, global media publications, governmental and nongovernmental institutions, financial reports, regulatory filings, and academic studies. The resulting performance information is aggregated into the KLD STATS database, which covers all Standard \& Poor's (S\&P) 500 constituents as of 1991, the 1,000 largest publicly traded U.S. firms from 2001 to 2002, and the 3,000 largest publicly traded U.S. firms thereafter.

\footnotetext{
15 Although the United States is a signatory to the Kyoto Protocol, the signature is merely symbolic (i.e., nonbinding), because it has neither ratified nor withdrawn from the protocol. Nevertheless, a federal objective of the current administration is to reduce greenhouse gas emissions back to 1990 levels by 2020, and an additional 80\% by 2050 . Next to this national objective, individual States have supplementary policies to cut emissions.
} 
To rank firms according to the quality of their environmental management, we focus on the qualitative performance indicators that are contained in the Environment dimension of KLD STATS. These indicators cover the strengths and concerns that each firm in the database displays with regard to its environmental activities. We exclude the categories Property, Plant, and Equipment and Ozone Depleting Chemicals from the set of available indicators, because of their limited and highly clustered observations.16 We also exclude an indicator for the firm's environmental reporting, Communications, to separate the effect of voluntary environmental disclosures. ${ }^{17}$ Panels A and B in Table 3.1 provide details on the indicators that comprise our measures of environmental management performance.

\section{TABLE 3.1}

\section{Environmental performance measures}

This table lists the performance indicators that we use to construct our measures of environmental management performance. Information on these qualitative indicators is collected from the Environment dimension in the KLD STATS database. Panel A reports the performance strength indicators for this dimension, and Panel B reports its performance concern indicators. If a firm displays a related environmental strength or concern, KLD assigns a value of zero or one to the corresponding indicator, where zero denotes "no concern/strength" and one denotes a "concern/ strength". We sum each group of indicators to respectively construct an aggregate measure for the firm's environmental management strengths, $E N V_{\text {Strengths, }}$, and concerns, $E N V_{\text {Concerns }}$.

\section{PANEL A: Performance strength indicators, $E N V_{\text {Strengths }}$}

Beneficial Products and Services

Pollution Prevention

Recycling

Clean Energy

Other Strength
The company derives substantial revenues from innovative remediation products, environmental services, or products with environmental benefits. (The term "environmental service" excludes services with questionable environmental effects, such as landfills, incinerators, waste-to-energy plants, and deep injection wells.)

The company has notably strong pollution prevention programs including both emissions reductions and toxic-use reduction programs.

The company either is a substantial user of recycled materials as raw materials in its manufacturing processes, or a major factor in the recycling industry.

The company has taken significant measures to reduce its impact on climate change and air pollution through use of renewable energy and clean fuels or through energy efficiency. The company has demonstrated a commitment to promoting climate-friendly policies and practices outside its own operations.

The company has demonstrated a superior commitment to management systems, voluntary programs, or other environmentally proactive activities.

\footnotetext{
${ }^{16}$ KLD has not passed judgment on the Property, Plant, and Equipment category since 1995, which leaves us with a single sample observation after database matching. The Ozone Depleting Chemicals category contains at most 22 observations, 15 of which are clustered around two companies.

${ }^{17}$ While voluntary environmental disclosures can contain useful information for decision makers, we choose to ignore them since they ultimately represent an unaudited self-portrayal of the firm's environmental performance. However, incorporating the Communications indicator into our analysis does not alter the significance of the presented findings.
} 
TABLE 3.1 (continued)

Measures of environmental management performance

\begin{tabular}{ll}
\hline \hline & PANEL B: Performance concern indicators, $\boldsymbol{E N V _ { \text { Concerns } }}$ \\
\hline Hazardous Waste & The company's liabilities for hazardous waste sites exceed $\$ 50$ million, or \\
the company has recently paid substantial fines or civil penalties for waste \\
management violations. \\
The company has recently paid substantial fines or civil penalties for \\
violations of air, water, or other environmental regulations, or it has a \\
pattern of regulatory controversies under the Clean Air Act, Clean Water \\
Act or other major environmental regulations. \\
The company's legal emissions of toxic chemicals (as defined by and \\
reported to the EPA) from individual plants into the air and water are \\
among the highest of the companies followed by KLD. \\
The company is a substantial producer of agricultural chemicals, i.e., \\
pesticides or chemical fertilizers. \\
The company derives substantial revenues from the sale of coal or oil and \\
Thimate Change \\
its derivative fuel products, or the company derives substantial revenues \\
indirectly from the combustion of coal or oil and its derivative fuel \\
products. Such companies include electric utilities, transportation \\
companies with fleets of vehicles, auto and truck manufacturers, and other \\
transportation equipment companies. In 1999, KLD added the climate \\
Change Concern. \\
The company has been involved in an environmental controversy that is not \\
covered by other KLD ratings.
\end{tabular}

KLD assigns a value of zero or one to each of the indicators, which respectively denote the absence and presence of a strength or concern. We sum the individual indicators to obtain measures for the total number of environmental strengths, $E N V_{\text {Strengths, }}$, and the total number of environmental concerns, $E N V_{\text {Concerns. }}$. This approach follows our objective to distinguish between the effects of corporate activities that increase environmental risks, and those that are aimed at mitigating the same. It also controls for earlier concerns that positive and negative social actions may be both empirically and conceptually distinct constructs (Mattingly and Berman, 2006).

\subsubsection{Credit risk measures}

We use three distinct measures of credit risk to test the relevance of environmental management for bond investors: the cost of debt financing, bond ratings, and long-term issuer ratings. Information on the cost of debt and bond ratings are collected from the Mergent Fixed Income Securities Database (FISD), which provides data on more than 140,000 publicly offered U.S. corporate bonds, together with more than 550 bond characteristics. We perform several screens to limit confounding effects that may result from bond specific characteristics: First, we focus our analysis on unsecured corporate bonds that are either classified as senior or senior-subordinated debt. Next, we exclude bonds with option or other nonstandard components (i.e., callable, puttable, convertible, exchangeable, preferred, perpetual, asset- 
backed, private placements, part of unit deals, sinking fund provisions). After the matching of our credit risk measures with the test and control variables, we are left with a sample of 2,242 bonds that were issued by 582 firms in the period from 1995 to 2006. FISD reports yield spreads for 2,119 of these bonds, and bond ratings for the entire sample.

Our first dependent variable is the firm's cost of debt financing, which we define as the market quoted yield spread of newly issued bonds, Spread. The yield spread equals the difference between the offering yield to maturity of a bond issue and the yield to maturity of a corresponding treasury bond. Consequently, it reflects the premium that the market charges borrowers for assuming the risk that they may default on their debt obligations. We study the cost of debt in its log form, $\ln ($ Spread), because of the significant positive skewness in the yield spread distribution.

The second dependent variable is the credit rating that is assigned to a particular bond issue, Bond Rating. We use an equally weighted average of S\&P and Moody's ratings to construct our bond ratings measure. In the case that only a single bond rating from either rating agency is available, we assign the full weight to this rating. To ensure a reasonable match with the issue yield spreads, we require that the distance between a bond's offering date and its rating date does not exceed 90 days, before adding a bond rating to the sample. We then recode the standard rating classifications into numerical values according to the conversion schedule in Panel A of Table 3.A1 (Ashbaugh-Skaife, Collins, and LaFond, 2006), provided in the Appendix. The values that we assign range on a seven-point scale, where one denotes the lowest $\left(\mathrm{CCC}^{+}-\mathrm{D}\right)$ and seven the highest (AAA) credit rating category.

Our third dependent variable is the Issuer Rating, which reflects the general creditworthiness of a firm in relation to its senior unsecured obligations. We obtain S\&P longterm issuer ratings from Compustat for the same period as for the other credit risk measures. After matching the data with the control variables our sample comprises 6,420 issuer ratings that were assigned to 1,094 firms. We follow the same approach as for the bond ratings to recode the Compustat rating classifications into a numerical ranking from one to seven.

\subsubsection{Control variables}

Our credit risk analysis incorporates two sets of control variables, which account for borrower and bond characteristics that previous studies have identified as cross-sectional determinants of credit risk (e.g., Ashbaugh-Skaife et al. , 2006; Bradley, Chen, Dallas, and Snyderwine, 2008; Bhojraj and Sengupta, 2003; Cremers, Nair, and Wei, 2007). Table 3.A2 in the appendix lists the control variables, together with their definitions and predicted credit risk relations.

The first set of control variables comprises bond issuer characteristics, which we collect from Compustat. Leverage is the financial leverage of the firm, defined as the ratio of its total liabilities to total assets. Size measures firm size, and is defined as the natural logarithm of the firm's total assets. Capital Intensity equals the ratio of fixed assets to total assets. Interest Coverage is the interest coverage ratio, defined as operating income before depreciation divided by interest expense. ROA measures the accounting return on assets, and is defined as the ratio of net income before extraordinary items to total assets. Loss is an indicator variable that equals one if a firm's net income before extraordinary items is negative in the current and prior fiscal year. A recurring negative net income can be an indicator for financial distress.

The second set of control variables accounts for bond issue specific characteristics, which we obtain from Mergent FISD. TTM is the time-to-maturity of a bond, measured in years. Issue 
Size equals the size of a bond issue, measured as the natural logarithm of its offering amount. The expected relation between the issue size of a bond and its default risk is ambiguous. Large debt issues are generally associated with higher liquidity, and thus expected to reduce the issue yield spread. However, large debt obligations also imply a higher default probability for the bond issuer, and higher expected absolute loss for the bondholder. Subordinate is an indicator variable that equals one if a bond's order of repayment classifies as senior-subordinated. ${ }^{18}$ Speculative is an indicator variable that equals one if a bond issue has a speculative credit grade, i.e., its bond rating is below $\mathrm{BBB}^{-}(\mathrm{S} \& \mathrm{P})$ or $\mathrm{Baa}^{3}$ (Moody's). Firms whose credit status is downgraded to speculative grade generally experience a significant markup in their cost of debt financing, due to the lower liquidity of their debt securities and higher default risk that accompany this downgrade.

We introduce a modified bond rating, BRmod, as additional control variable for the cost of debt analysis. BRmod is defined as the residual of a bond rating regression on $E N V_{\text {Strengths }}$ and $E N V_{\text {Concerns. }}$. This approach follows a procedure that is frequently used in earlier studies on the cost of debt, to place an orthogonality condition on Bond Rating with respect to environmental management information (see, e.g., Datta, Iskandar-Datta, and Patel, 1999; Anderson, Mansi, and Reeb, 2003; Klock, Mansi, and Maxwell, 2005; Ortiz-Molina, 2006; Goss and Roberts, 2009; Schneider, 2010). We include the modified bond rating to control for additional credit risk determinants that are missing from our set of control variables, while accounting for the fact that credit rating agencies scrutinize borrowing firms for environmental liabilities (Standard \& Poor's, 2008).

\section{TABLE 3.2}

\section{Industry distribution}

This table summarizes the industry distribution of our credit risk samples. The sample observations are allocated to industry classifications according to their membership in a major SIC division.

\begin{tabular}{lrrr}
\hline \hline SIC Division & Cost of Debt & Bond Rating & Issuer Rating \\
\hline Agriculture, Forestry, Fishing & $0.05 \%$ & $0.04 \%$ & $0.21 \%$ \\
Mining & $3.88 \%$ & $4.06 \%$ & $5.14 \%$ \\
Construction & $2.34 \%$ & $2.25 \%$ & $1.44 \%$ \\
Manufacturing & $41.66 \%$ & $40.84 \%$ & $45.01 \%$ \\
Transportation, Communication, & $19.34 \%$ & $19.56 \%$ & $17.94 \%$ \\
Electric, Gas, Sanitary services & & & \\
Wholesale trade & $2.34 \%$ & $2.25 \%$ & $2.58 \%$ \\
Retail trade & $7.61 \%$ & $7.95 \%$ & $7.79 \%$ \\
Finance, Insurance, Real estate & $13.03 \%$ & $13.86 \%$ & $9.74 \%$ \\
Services & $9.57 \%$ & $8.96 \%$ & $9.66 \%$ \\
Nonclassifiable establishment & $0.19 \%$ & $0.22 \%$ & $0.48 \%$ \\
$\quad$ \# Observations & 2,119 & 2,242 & 6,447 \\
\hline
\end{tabular}

\footnotetext{
${ }^{18}$ This definition applies for the cost of debt and bond rating analyses. In the issuer rating analysis, Subordinated denotes an indicator variable that equals one if a firm has subordinated debt (data80) in its capital structure, and zero otherwise.
} 


\section{TABLE 3.3}

\section{Descriptive statistics}

This table provides summary statistics of the test variables for a sample of 2,242 bond issues over the period from 1995 to 2006. Note that log-transformed variables are reported in real values to facilitate their interpretation (i.e., In(Spread), Size, Issue Size). Spread is the issue yield spread expressed in basis points, defined as the difference between a bond issue's offering yield and the yield of its Treasury benchmark. $E N V_{\text {Strengths }}$ and $E N V_{\text {Concerns }}$ respectively denote the sum of a firm's environmental management strengths and concerns. $E N V_{\text {Total }}$ equals the difference between $E N V_{\text {Strengths }}$ and $E N V_{\text {Concerns, }}$, and is a proxy for the firm's aggregate environmental performance. Bond Rating is the issue-specific credit rating, defined as the average S\&P and Moody's rating assigned to a particular bond issue. Issuer Rating is the S\&P long-term domestic issuer rating. Leverage is defined as the ratio of total liabilities to total assets; Size measures firm size, defined as the natural logarithm of total assets; Capital Intensity is the ratio of fixed assets to total assets; Interest Coverage is a solvency ratio expressed as multiple, defined as operating income before depreciation divided by interest expense; $R O A$ is defined as the ratio of income before extraordinary items to total assets; Loss is an indicator variable that equals 1 if a firm's net income before extraordinary items is negative in the current and prior fiscal year. TTM is the bond issue's time to maturity stated in years; Issue Size is the bond issue's dollar denomination, defined as the natural logarithm of its initially offered par value; Subordinate is an indicator variable that equals 1 if the bond issue is denoted senior-subordinated; Speculative is defined as an indicator variable that equals 1 for bond issues that are assigned a speculative-grade credit rating. All continuous variables are winsorized at the $1^{\text {st }}$ and $99^{\text {th }}$ percentile.

\begin{tabular}{|c|c|c|c|c|c|c|}
\hline Variable & \# Obs. & Mean & Std. Dev. & Median & Min. & Max. \\
\hline \multicolumn{7}{|l|}{ Environmental Performance } \\
\hline $\mathrm{ENV}_{\text {Strengths }}$ & 2,242 & 0.30 & 0.59 & 0 & 0 & 4 \\
\hline $\mathrm{ENV}_{\text {Concerns }}$ & 2,242 & 0.67 & 1.06 & 0 & 0 & 5 \\
\hline $\mathrm{ENV}_{\text {Total }}$ & 2,242 & -0.37 & 1.07 & 0 & -4 & 4 \\
\hline \multicolumn{7}{|l|}{ Credit Risk Measures } \\
\hline Spread (in bps) & 2,119 & 149.85 & 104.59 & 120 & 3 & 945 \\
\hline Bond Rating & 2,242 & 4.41 & 0.93 & 4 & 1 & 7 \\
\hline Issuer Rating & 6,420 & 3.73 & 1.18 & 4 & 1 & 7 \\
\hline \multicolumn{7}{|l|}{ Issuer Specific Controls } \\
\hline Leverage (in \%) & 2,242 & 69.38 & 15.18 & 68.62 & 36.08 & 123.09 \\
\hline Size (in $\mathrm{BM} \$$ ) & 2,242 & 39.21 & 93.63 & 12.54 & 0.28 & 979.41 \\
\hline Capital Intensity (in \%) & 2,242 & 57.64 & 40.28 & 53.82 & 0.06 & 174.85 \\
\hline Interest Coverage & 2,242 & 9.17 & 8.99 & 6.21 & -1.51 & 45.96 \\
\hline ROA (in \%) & 2,242 & 4.23 & 4.59 & 3.64 & -21.73 & 15.76 \\
\hline Loss & 2,242 & 0.03 & 0.18 & 0 & 0 & 1 \\
\hline \multicolumn{7}{|l|}{ Issue Specific Controls } \\
\hline Subordinated & 2,242 & 0.02 & 0.15 & 0 & 0 & 1 \\
\hline TTM (in years) & 2,242 & 12.50 & 11.85 & 10 & 0.25 & 100 \\
\hline Issue Size (in MM\$) & 2,242 & 438.66 & 399.14 & 300 & 10 & 2,500 \\
\hline Speculative & 2,242 & 0.13 & 0.34 & 0 & 0 & 1 \\
\hline
\end{tabular}




\subsubsection{Descriptive statistics}

In Table 3.2, we summarize the sample distribution of our credit risk measures across industries. The observations are allocated into industry classifications according to the debt issuer's membership in a major SIC division. The majority of observations is concentrated in the Manufacturing division (41-45\%), ${ }^{19}$ or Transportation, Communication, Electric, Gas, and Sanitary Services division (18-20\%).

We present summary statistics on our regression variables in Table 3.3. ${ }^{20}$ The logarithmic variables $\ln ($ Spread), Size, and Issue Size are reported in real values to facilitate interpretation. To ensure that the significance of our results is not driven by extreme outliers, we winsorize all continuous variables at the one-percent level.

An inspection of the bond statistics confirms that our sample is representative of bond issues with similar features that were traded in the credit market during the period of interest. The median Spread equals 120 basis points, and shows considerable sample variation with a standard deviation of 105 basis points and a range of 9.42\%. The median Bond Rating equals $\mathrm{BBB}^{+} / \mathrm{Baa}^{3}$, and $13 \%$ of all bond ratings are rated below investment grade. Only $2 \%$ of the bonds classify as debt issues whose seniority is denoted senior-subordinated. The median issue size of the bonds is $\$ 300$ million, and their median maturity is ten years. The bond issuer statistics show that the firms in our sample are relatively large and highly levered. Their median Size is reported at about $\$ 12.54$ billion (total assets), and their median Leverage at $69 \%$. However, both measures show considerable variation within the sample. The median Issuer Rating for the bond issuing firms is $\mathrm{BBB}^{+}$, which is consistent with the presented bond rating statistics.

The data show no signs of multicollinearity in correlation as well as variance inflation factor (VIF) tests.

\subsection{Empirical Analysis}

\subsubsection{Environmental management and the cost of debt}

In the first step of our analysis, we regress the cost of debt on our measures of environmental management performance and the two sets of control variables. The general model for the cost of debt financing has the form:

$$
\ln \left(\text { Spread }_{i, t}=\alpha+\beta E N V_{i, t}+\sum_{k=1}^{K} \gamma_{k} \text { Issuer }_{k, i, t}+\sum_{j=1}^{J} \delta_{j} \text { Issue }_{j, i, t}+\varepsilon_{i, t}\right.
$$

where $E N V$ represents a vector of environmental performance measures that capture the firm's environmental management strengths and concerns $\left(E N V_{\text {Strengths }} ; E N V_{\text {Concerns }}\right)$, and Issuer and Issue denote the sets of corresponding characteristics that are employed as control variables. Throughout our analysis, all regression models control for year fixed effects and

\footnotetext{
${ }^{19}$ These percentage numbers refer to the bond issue sample and issuer ratings sample, respectively.

${ }^{20}$ The presented summary statistics are based on the bond issue sample. Corresponding summary statistics for our issuer ratings sample are excluded for brevity, but available on request.
} 
industry fixed effects (2-digit SIC codes). We estimate the cost of debt model using pooled OLS regressions, and assess the significance of the coefficient estimates using robust standard errors that are clustered at the industry level (2-digit SIC codes). The clustering of errors makes the assumption that observations are independent across industries, but not necessarily independent within industries. Not correcting standard errors for correlation within clusters can result in exaggerated $t$-statistics (Petersen, 2009). Given its minimal assumptions about the correlation structure of the error term, the clustering method is likely to provide the most conservative standard errors.

Table 3.4 reports multivariate regression results for the cost of debt analysis. Column (1a) summarizes the outcomes for our basic model, which only comprises the sets of control variables. In Column (1b), we present the findings for the general model. Column (1c) contains the results for the most comprehensive model specification, which adds the modified bond rating as a control for additional credit risk determinants. Our confidence in the model's fit is supported by the adjusted $\mathrm{R}^{2} \mathrm{~s}$, which range between 0.70 and 0.74 . Moreover, the control variables have coefficients that are statistically significant in almost all cases, and signs that correspond with their predicted relations across all model specifications.

The regression results support our hypotheses that environmental management is a valuerelevant determinant of bond prices. The general model reports a negative and statistically significant factor loading on $E N V_{\text {Strengths }}$, and a positive and statistically significant factor loading on $E N V_{\text {Concerns. }}$. Extending the model with BRmod further increases the statistical significance of both coefficients. Our findings illustrate that borrowers who engage in environmentally risky activities are charged a premium on their cost of debt financing, which substantiates earlier evidence that the credit market is sensitive to environmental liabilities. Furthermore, they show that firms with proactive environmental engagement pay a lower cost of debt financing.

To assess the economic significance of our findings, we estimate the expected change in the cost of debt given a one standard deviation change in the environmental performance measures. We calculate that a standard deviation increase in $E N V_{\text {Strengths }}$ corresponds with a reduction in the yield spread by 6 basis points, while a standard deviation increase in $E N V_{\text {Concerns }}$ is associated with an increase in the yield spread by 5 basis points. We arrive at these estimates by calculating standardized coefficients for $E N V_{\text {Strengths }}(-0.0487)$ and $E N V_{\text {Concerns }}(0.0411)$ based on the most comprehensive model specification. Since the cost of debt is in log-form, a standard deviation change in $E N V_{\text {Strengths }}$ or $E N V_{\text {Concerns }}$ translates into a 4.87\% and $4.11 \%$ change in Spread, respectively. Using the median Spread as a conservative reference point, we infer our final estimates after rounding. The maximum impact of a combined change in our environmental performance measures on the annual cost of debt is estimated at 64 basis points, or 53\% of the $\$ 3.6$ million annual median interest expense that is payable in excess of the Treasury benchmark rate. ${ }^{21}$

\footnotetext{
${ }^{21}$ If we base our estimation on the mean Spread $(150 \mathrm{bps})$, a standard deviation change in $E N V_{\text {Strengths }}$ is associated with a $7 \mathrm{bps}$ decrease in the cost of debt, while an equivalent change in $E N V_{\text {concerns }}$ is associated with a 6 bps increase in the cost of debt. The maximum impact on the cost of debt then equals 80 bps per year.
} 


\section{TABLE 3.4}

\section{Cost of debt regressions}

This table shows the effect of environmental management performance on the cost of debt financing. We regress the $\log$-transformed yield spread $(\ln ($ Spread $))$ on measures of environmental management performance $\left(E N V_{\text {Strengths }}, E N V_{\text {Concerns }}\right)$, and an array of issuer and issue control variables. The general model is extended with a modified bond rating variable (BRmod) that is orthogonal to the environmental performance measures, to account for credit relevant information that is not captured by our control variables but incorporated by credit rating agencies. All models include year and industry fixed effects (2-digit SIC codes), and estimate standard errors that are clustered at the industry level (2-digit SIC codes). Robust $t$-statistics are reported in parentheses below the coefficients.

\begin{tabular}{|c|c|c|c|}
\hline & (1a) & (1b) & (1c) \\
\hline $\mathrm{ENV}_{\text {Strengths }}$ & & $\begin{array}{l}-0.0387 * * \\
(-2.06)\end{array}$ & $\begin{array}{l}-0.0839 * * * \\
(-4.79)\end{array}$ \\
\hline $\mathrm{ENV}_{\text {Concerns }}$ & & $\begin{array}{l}0.0491 \text { *** } \\
(2.91)\end{array}$ & $\begin{array}{l}0.0388 * * * \\
(3.04)\end{array}$ \\
\hline BRmod & & & $\begin{array}{l}-0.3259 * * * \\
(-14.15)\end{array}$ \\
\hline Leverage & $\begin{array}{l}0.0040 * * * \\
(3.25)\end{array}$ & $\begin{array}{l}0.0038 * * * \\
(3.14)\end{array}$ & $\begin{array}{l}0.0031 * * \\
(2.52)\end{array}$ \\
\hline Size & $\begin{array}{l}-0.1327 * * * \\
(-8.82)\end{array}$ & $\begin{array}{l}-0.1427 * * * \\
(-9.30)\end{array}$ & $\begin{array}{l}-0.0693 * * * \\
(-3.97)\end{array}$ \\
\hline Capital Intensity & $\begin{array}{l}-0.0010 * * \\
(-2.06)\end{array}$ & $\begin{array}{l}-0.0011 * \\
(-1.83)\end{array}$ & $\begin{array}{l}-0.0001 \\
(-0.17)\end{array}$ \\
\hline Interest Coverage & $\begin{array}{l}-0.0066^{* * *} \\
(-2.09)\end{array}$ & $\begin{array}{l}-0.0065^{* *} \\
(-2.12)\end{array}$ & $\begin{array}{l}-0.0025 \\
(-1.12)\end{array}$ \\
\hline ROA & $\begin{array}{l}-0.0248 * * * \\
(-6.20)\end{array}$ & $\begin{array}{l}-0.0248 * * * \\
(-6.71)\end{array}$ & $\begin{array}{l}-0.0159 * * * \\
(-5.17)\end{array}$ \\
\hline Loss & $\begin{array}{l}0.1569 * * * \\
(3.68)\end{array}$ & $\begin{array}{l}0.1578 * * * \\
(3.71)\end{array}$ & $\begin{array}{l}0.1216^{*} \\
(1.70)\end{array}$ \\
\hline Subordinated & $\begin{array}{l}0.1964 * * \\
(2.53)\end{array}$ & $\begin{array}{l}0.1974 * * * \\
(2.64)\end{array}$ & $\begin{array}{l}0.2008 * * * \\
(2.89)\end{array}$ \\
\hline TTM & $\begin{array}{l}0.0098 * * * \\
(8.52)\end{array}$ & $\begin{array}{l}0.0097 * * * \\
(8.50)\end{array}$ & $\begin{array}{l}0.0096^{* * *} \\
(9.31)\end{array}$ \\
\hline Issue size & $\begin{array}{l}0.0220 \\
(0.82)\end{array}$ & $\begin{array}{l}0.0207 \\
(0.80)\end{array}$ & $\begin{array}{l}0.0300 \\
(1.07)\end{array}$ \\
\hline Speculative & $\begin{array}{l}0.5936 * * * \\
(13.07)\end{array}$ & $\begin{array}{l}0.5961 * * * \\
(13.00)\end{array}$ & \\
\hline Year Fixed Effects & Yes & Yes & Yes \\
\hline Industry Fixed Effects & Yes & Yes & Yes \\
\hline Adj. $R^{2}$ & 0.70 & 0.70 & 0.74 \\
\hline \# Observations & 2,119 & 2,119 & 2,068 \\
\hline
\end{tabular}

$* * * \mathrm{p}<0.01, * * \mathrm{p}<0.05, * \mathrm{p}<0.1$ 


\subsubsection{Environmental management and credit ratings}

We conduct additional tests on the relevance of environmental management for credit risk, by studying the link between our environmental performance measures and credit ratings. Our first set of regressions assesses the link with bond ratings. The general model takes the form:

$$
\text { Bond Rating } \text { Rit }=\alpha+\beta \text { ENV }_{i, t}+\sum_{k=1}^{K} \gamma_{k} \text { Issuer }_{k, i, t}+\sum_{l=1}^{L} \delta_{l} \text { Issue }_{l, i, t}+\varepsilon_{i, t}
$$

where Bond Rating is the credit rating assigned to a specific bond issue of a firm, and the control variables are defined almost identically to those in the cost of debt analysis. We exclude Speculative and BRmod from the set of issue specific control variables, since their information content derives from the dependent variable. To account for the ordinal nature of the credit ratings, we perform ordered probit regressions on the pooled bond ratings sample to obtain coefficient estimates and corresponding z-statistics. Panel A of Table 3.5 reports the regression output for the bond ratings analysis.

The coefficients of the control variables are again mostly statistically significant, and have signs that are consistent with prior studies. The time-to-maturity variable forms the only exception, with a coefficient that contradicts its predicted sign, but although this outcome is unexpected, our study is not the first to observe this relation (see Bhojraj and Sengupta, 2003). More importantly, the results for the environmental performance measures are again consistent with our first two hypotheses: The general model specification produces a positive and statistically significant coefficient for $E N V_{\text {Strengths, }}$, and a negative and statistically significant coefficient for $E N V_{\text {Concerns. }}$. Consequently, firms with better environmental management capabilities or activities are more likely to receive a higher bond rating, while firms with more environmental concerns are associated with lower bond ratings.

To corroborate our evidence on the link between environmental management and credit ratings, we study a supplementary sample of long-term issuer ratings. The general model for the issuer ratings takes the form:

$$
\text { Issuer Rating }_{i, t}=\alpha+\beta E N V_{i, t}+\sum_{k=1}^{K} \gamma_{k} \text { Issuer }_{k, i, t}+\varepsilon_{i, t}
$$

The issuer rating analysis only incorporates control variables that capture firm specific characteristics, given that the dependent variable reflects the general creditworthiness of a rated entity, rather than that of a particular bond issue. The Subordinated variable is accordingly redefined as an indicator variable that equals one if the firm has subordinated debt in its capital structure, and zero otherwise.

Panel B of Table 3.5 summarizes the results for the issuer ratings regressions. The coefficients of the control variables have their expected signs and are mostly statistically significant. The coefficients of $E N V_{\text {Strengths }}$ and $E N V_{\text {Concerns }}$ are generally consistent with the bond rating results, although only the measure for environmental management concerns achieves statistical significance. This finding is indicative that information related to environmental concerns plays a more prominent role for rating agencies when assessing the general creditworthiness of borrowers. 


\section{TABLE 3.5}

\section{Credit ratings regressions}

This table summarizes the effect of environmental management performance on credit ratings. Panel A reports results for ordered probit regressions of equally weighted S\&P and Moody's bond ratings (Bond Rating) on measures of environmental management performance $\left(E N V_{\text {Strengths }}, E N V_{\text {Concerns }}\right)$, and an array of issuer and issue specific control variables. Panel B reports results for ordered probit regressions of S\&P long-term domestic issuer ratings (Issuer Rating) on the same environmental performance measures, and a set of issuer specific control variables. All models include year and industry fixed effects (2-digit SIC codes), and estimate standard errors that are clustered at the industry level (2-digit SIC codes). Robust $t$-statistics are reported in parentheses below the coefficients.

\begin{tabular}{|c|c|c|c|c|}
\hline & \multicolumn{2}{|c|}{ Panel A: Bond Ratings } & \multicolumn{2}{|c|}{ Panel B: Issuer Ratings } \\
\hline & $(2 a)$ & $(2 b)$ & $(2 a)$ & $(2 b)$ \\
\hline $\mathrm{ENV}_{\text {Strengths }}$ & & $\begin{array}{l}0.1622^{*} \\
(1.93)\end{array}$ & & $\begin{array}{l}0.0745 \\
(1.48)\end{array}$ \\
\hline $\mathrm{ENV}_{\text {Concerns }}$ & & $\begin{array}{l}-0.1925^{* *} \\
(-2.18)\end{array}$ & & $\begin{array}{l}-0.1458^{* *} \\
(-2.09)\end{array}$ \\
\hline Leverage & $\begin{array}{l}-0.0169 * * * \\
(-3.93)\end{array}$ & $\begin{array}{l}-0.0165 * * * \\
(-3.90)\end{array}$ & $\begin{array}{l}-0.0106^{* * * *} \\
(-3.76)\end{array}$ & $\begin{array}{l}-0.0104 * * * \\
(-3.69)\end{array}$ \\
\hline Size & $\begin{array}{l}0.5708 * * * \\
(4.68)\end{array}$ & $\begin{array}{l}0.6164 * * * \\
(5.99)\end{array}$ & $\begin{array}{l}0.5329 * * * \\
(8.67)\end{array}$ & $\begin{array}{l}0.5584 * * * \\
(10.10)\end{array}$ \\
\hline Capital Intensity & $\begin{array}{l}0.0067 * * * \\
(3.21)\end{array}$ & $\begin{array}{l}0.0069 * * * \\
(3.19)\end{array}$ & $\begin{array}{l}0.0041 * * * \\
(3.19)\end{array}$ & $\begin{array}{l}0.0046^{* * * *} \\
(3.49)\end{array}$ \\
\hline Interest Coverage & $\begin{array}{l}0.0321 * * \\
(2.29)\end{array}$ & $\begin{array}{l}0.0323 * * \\
(2.31)\end{array}$ & $\begin{array}{l}0.0007 \\
(0.59)\end{array}$ & $\begin{array}{l}0.0006 \\
(0.51)\end{array}$ \\
\hline ROA & $\begin{array}{l}0.0739 * * * \\
(3.88)\end{array}$ & $\begin{array}{l}0.0746 * * * \\
(4.23)\end{array}$ & $\begin{array}{l}0.0565^{* * * *} \\
(10.65)\end{array}$ & $\begin{array}{l}0.0567 * * * \\
(10.83)\end{array}$ \\
\hline Loss & $\begin{array}{l}-0.9782 * * * * \\
(-4.14)\end{array}$ & $\begin{array}{l}-0.9814 * * * \\
(-4.02)\end{array}$ & $\begin{array}{l}-0.3809 * * * \\
(-5.18)\end{array}$ & $\begin{array}{l}-0.3914 * * * \\
(-5.40)\end{array}$ \\
\hline Subordinated & $\begin{array}{l}-1.2784 * * * \\
(-4.27)\end{array}$ & $\begin{array}{l}-1.2924 * * * \\
(-4.45)\end{array}$ & $\begin{array}{l}-0.3634 * * * \\
(-4.27)\end{array}$ & $\begin{array}{l}-0.3543 * * * \\
(-4.26)\end{array}$ \\
\hline TTM & $\begin{array}{l}0.0061 * * \\
(1.99)\end{array}$ & $\begin{array}{l}0.0068 * * \\
(2.31)\end{array}$ & & \\
\hline Issue size & $\begin{array}{l}-0.0028 \\
(-0.05)\end{array}$ & $\begin{array}{l}0.0002 \\
(0.00)\end{array}$ & & \\
\hline Year Fixed Effects & Yes & Yes & Yes & Yes \\
\hline Industry Fixed Effects & Yes & Yes & Yes & Yes \\
\hline Pseudo $\mathrm{R}^{2}$ & 0.33 & 0.34 & 0.23 & 0.23 \\
\hline \# Observations & 2,242 & 2,242 & 6,420 & 6,420 \\
\hline
\end{tabular}

$* * * \mathrm{p}<0.01, * * \mathrm{p}<0.05, * \mathrm{p}<0.1$ 


\subsubsection{Analyzing the effect of individual environmental activities}

To enhance our understanding of the link between environmental management and credit risk, we disaggregate both environmental performance measures and regress our credit risk proxies on the underlying factors. Since the environmental activities within each performance measure are partially correlated, we first orthogonalize them with respect to each other to document their separate effects. ${ }^{22}$ Table 3.6 summarizes the regression results for the most comprehensive model specifications. We do not report on the control variables for brevity.

The coefficients on the environmental performance categories generally carry their expected signs. Among the tested performance strengths, the categories Beneficial Products, Clean Energy, and Other Strength load statistically significant. For the performance concerns, we document significant coefficients on all categories. However, the categories that are most consistently associated with the different credit risk measures are Regulatory Problems, Substantial Emissions, and Climate Change. The only unexpected outcome is the negative and significant loading on Recycling in the issuer ratings regression, which is however not sustained in further tests.

The presented evidence corresponds with the idea that climate change related issues and regulatory concerns are linked to a higher expected default risk of firms. Moreover, our analysis suggests that the better credit standing which we observe for firms with proactive environmental activities is not only linked to a reduction in environmental risk exposure, but also appears to be associated with an improvement in cash flows.

\subsubsection{High-risk industries}

The credit market is expected to be particularly sensitive to the environmental performance of borrowers in inherently risky industries, because of their higher susceptibility to environmental violations and the associated costs. To test this hypothesis, we extend the credit risk models with two interaction variables that combine our measures of environmental performance with an indicator variable, HighRisk, which denotes whether or not a firm operates in an environmentally risky industry. Using SIC codes, we identify 92 firms in the following high risk industries: paper and allied products (2600), chemicals and allied products $(2800,5160$, $5161,5169)$, petroleum refining $(2910,2911,2900)$, primary metal (3300), and mining (1000, 1200). Our selection is guided by earlier environmental performance studies (e.g., Cormier and Magnan, 1997). Since credit rating agencies account for industry specific risks in their evaluations, we perform the cost of debt regressions with and without the modified bond rating to control that BRmod does not capture part of the predicted effect.

\footnotetext{
22 Since this modification of the environmental performance categories complicates the interpretation of the regression coefficients, we run regressions without the orthogonality conditions to corroborate our inferences. The respective output is presented in Table A3 of the Appendix, and confirms that the outcomes of both sets of regressions are very similar.
} 
TABLE 3.6

\section{Credit risk implications of environmental performance activities}

This table summarizes the effect of individual environmental performance factors on credit risk. We decompose our measures of environmental management performance $\left(\mathrm{ENV}_{\text {Strengths }}, \mathrm{ENV}_{\text {Concerns }}\right)$, and test the effect of their components on the cost of debt financing and credit ratings. To account for correlation within each of the performance measures, we orthogonalize the environmental activities with respect to each other. The control variables are not reported for brevity. All models control for year and industry fixed effects (2-digit SIC codes), and estimate standard errors that are clustered at the industry level (2-digit SIC code). Robust $t$-statistics are reported in parentheses below the coefficients.

\begin{tabular}{|c|c|c|c|}
\hline & $\ln ($ Spread $)$ & Bond Rating & Issuer Rating \\
\hline \multicolumn{4}{|l|}{$\mathrm{ENV}_{\text {Strengths }}$} \\
\hline Beneficial Products & $\begin{array}{l}-0.1900 * * * \\
(-3.47)\end{array}$ & $\begin{array}{l}0.0393 \\
(0.15)\end{array}$ & $\begin{array}{l}0.3550 * * * \\
(4.08)\end{array}$ \\
\hline Pollution Prevention & $\begin{array}{l}0.0023 \\
(0.03)\end{array}$ & $\begin{array}{l}0.2461 \\
(0.68)\end{array}$ & $\begin{array}{l}0.1898 \\
(0.85)\end{array}$ \\
\hline Recycling & $\begin{array}{l}-0.1257 \\
(-1.45)\end{array}$ & $\begin{array}{l}-0.0118 \\
(-0.04)\end{array}$ & $\begin{array}{l}-0.3450 * \\
(-1.72)\end{array}$ \\
\hline Clean Energy & $\begin{array}{l}-0.0704 * * * \\
(-2.62)\end{array}$ & $\begin{array}{l}0.2721 * * \\
(2.08)\end{array}$ & $\begin{array}{l}0.1207 \\
(0.42)\end{array}$ \\
\hline Other Strength & $\begin{array}{l}-0.1856^{* * *} \\
(-2.00)\end{array}$ & $\begin{array}{l}0.2888 * \\
(1.88)\end{array}$ & $\begin{array}{l}-0.1082 \\
(-0.72)\end{array}$ \\
\hline \multicolumn{4}{|l|}{$\mathrm{ENV}_{\text {Concerns }}$} \\
\hline Hazardous Waste & $\begin{array}{l}0.0197 \\
(0.43)\end{array}$ & $\begin{array}{l}-0.4161 \\
(-1.37)\end{array}$ & $\begin{array}{l}-0.3515^{*} \\
(-1.90)\end{array}$ \\
\hline Regulatory Problems & $\begin{array}{l}0.1339 * * \\
(2.15)\end{array}$ & $\begin{array}{l}-0.5917^{*} \\
(-1.95)\end{array}$ & $\begin{array}{l}-0.6784 * * * \\
(-3.11)\end{array}$ \\
\hline Substantial Emissions & $\begin{array}{l}0.1478 * * \\
(2.46)\end{array}$ & $\begin{array}{l}-0.5933 \\
(-1.59)\end{array}$ & $\begin{array}{l}-0.4252 * * \\
(-2.33)\end{array}$ \\
\hline Agricultural Chemicals & $\begin{array}{l}0.0794 * * \\
(2.21)\end{array}$ & $\begin{array}{l}-0.4475 \\
(-1.34)\end{array}$ & $\begin{array}{l}0.0022 \\
(0.01)\end{array}$ \\
\hline Climate Change & $\begin{array}{l}0.1395 * * * \\
(2.86)\end{array}$ & $\begin{array}{l}-0.6838 * \\
(-1.73)\end{array}$ & $\begin{array}{l}-0.5341 * * \\
(-2.02)\end{array}$ \\
\hline Other Concern & $\begin{array}{l}0.1697 * * * \\
(4.05)\end{array}$ & $\begin{array}{l}-0.1842 \\
(-0.74)\end{array}$ & $\begin{array}{l}0.1668 \\
(0.59)\end{array}$ \\
\hline Year Fixed Effects & Yes & Yes & Yes \\
\hline Industry Fixed Effects & Yes & Yes & Yes \\
\hline Adj. $R^{2} /$ Pseudo $R^{2}$ & 0.72 & 0.35 & 0.26 \\
\hline \# Observations & 1,545 & 1,674 & 5,291 \\
\hline
\end{tabular}

$* * * \mathrm{p}<0.01, * * \mathrm{p}<0.05, * \mathrm{p}<0.1$ 
TABLE 3.7

Environmental performance and credit risk: High-risk industries

This table reports the effect of environmental management performance on credit risk for firms that operate in industries with intrinsically higher environmental risk. We regress the cost of debt and credit ratings on measures of environmental management performance $\left(E N V_{\text {Strengths }}, E N V_{\text {Concerns }}\right)$ and respective interaction terms (ENV $V_{\text {Strengths }} *$ HighRisk, ENV $V_{\text {Concerns }} *$ HighRisk), while controlling for issuer and issue specific control variables. HighRisk denotes an indicator variable that equals one if a firm operates in the paper and allied products, chemicals and allied products, petroleum refining, primary metal industry, or mining sector; and otherwise zero. All models include year and industry fixed effects (2-digit SIC codes), and estimate standard errors that are clustered at the industry level (2-digit SIC codes). Robust $t$-statistics are reported in parentheses below the coefficients.

\begin{tabular}{|c|c|c|c|c|}
\hline & $\ln ($ Spread $)$ & $\ln ($ Spread $)$ & Bond Rating & Issuer Rating \\
\hline $\mathrm{ENV}_{\text {Strengths }}$ & $\begin{array}{l}-0.0811 \text { *** } \\
(-4.24)\end{array}$ & $\begin{array}{l}-0.0297 \\
(-1.11)\end{array}$ & $\begin{array}{l}0.1289 \\
(1.21)\end{array}$ & $\begin{array}{l}0.0017 \\
(0.03)\end{array}$ \\
\hline $\mathrm{ENV}_{\text {Concerns }}$ & $\begin{array}{l}0.0474 * * * \\
(3.02)\end{array}$ & $\begin{array}{l}0.0578 * * * \\
(2.58)\end{array}$ & $\begin{array}{l}-0.2026^{*} \\
(-1.72)\end{array}$ & $\begin{array}{l}-0.1341 \\
(-1.19)\end{array}$ \\
\hline $\mathrm{ENV}_{\text {Strengths }}{ }^{*}$ HighRisk & $\begin{array}{l}-0.0144 \\
(-0.38)\end{array}$ & $\begin{array}{l}-0.0278 \\
(-0.55)\end{array}$ & $\begin{array}{l}0.1348 \\
(0.96)\end{array}$ & $\begin{array}{l}0.2074 * * \\
(2.44)\end{array}$ \\
\hline $\mathrm{ENV}_{\text {Concerns }}{ }^{*}$ HighRisk & $\begin{array}{l}-0.0208 \\
(-1.18)\end{array}$ & $\begin{array}{l}-0.0285 \\
(-0.88)\end{array}$ & $\begin{array}{l}0.0060 \\
(0.03)\end{array}$ & $\begin{array}{l}-0.0170 \\
(-0.12)\end{array}$ \\
\hline HighRisk & $\begin{array}{l}-0.1971 \text { *** } \\
(-2.81)\end{array}$ & $\begin{array}{l}-0.1912 * \\
(-1.88)\end{array}$ & $\begin{array}{l}0.1792 \\
(0.30)\end{array}$ & $\begin{array}{l}-0.7395 \\
(-1.50)\end{array}$ \\
\hline BRmod & $\begin{array}{l}-0.3255^{* * *} \\
(-14.04)\end{array}$ & & & \\
\hline Leverage & $\begin{array}{l}0.0030 * * \\
(2.43)\end{array}$ & $\begin{array}{l}0.0056^{* * * *} \\
(3.51)\end{array}$ & $\begin{array}{l}-0.0163 * * * \\
(-3.76)\end{array}$ & $\begin{array}{l}-0.0103 * * * \\
(-3.67)\end{array}$ \\
\hline Size & $\begin{array}{l}-0.0691 * * * \\
(-3.99)\end{array}$ & $\begin{array}{l}-0.1767 * * * \\
(-11.96)\end{array}$ & $\begin{array}{l}0.6168 * * * \\
(5.99)\end{array}$ & $\begin{array}{l}0.5609 * * * \\
(10.04)\end{array}$ \\
\hline Capital Intensity & $\begin{array}{l}-0.0001 \\
(-0.11)\end{array}$ & $\begin{array}{l}-0.0014 * * \\
(-2.21)\end{array}$ & $\begin{array}{l}0.0069 * * * \\
(3.11)\end{array}$ & $\begin{array}{l}0.0047 * * * \\
(3.51)\end{array}$ \\
\hline Interest Coverage & $\begin{array}{l}-0.0025 \\
(-1.11)\end{array}$ & $\begin{array}{l}-0.0078 * * \\
(-2.42)\end{array}$ & $\begin{array}{l}0.0323^{* *} \\
(2.31)\end{array}$ & $\begin{array}{l}0.0007 \\
(0.52)\end{array}$ \\
\hline ROA & $\begin{array}{l}-0.0161 * * * \\
(-5.20)\end{array}$ & $\begin{array}{l}-0.0285 * * * \\
(-5.67)\end{array}$ & $\begin{array}{l}0.0750 * * * \\
(4.30)\end{array}$ & $\begin{array}{l}0.0567 * * * \\
(11.09)\end{array}$ \\
\hline Loss & $\begin{array}{l}0.1250^{*} \\
(1.72)\end{array}$ & $\begin{array}{l}0.2957 * * * \\
(6.63)\end{array}$ & $\begin{array}{l}-0.9851 * * * \\
(-4.03)\end{array}$ & $\begin{array}{l}-0.3863 * * * \\
(-5.37)\end{array}$ \\
\hline Subordinated & $\begin{array}{l}0.2008 * * * \\
(2.88)\end{array}$ & $\begin{array}{l}0.4748 * * * \\
(4.45)\end{array}$ & $\begin{array}{l}-1.2917 * * * \\
(-4.44)\end{array}$ & $\begin{array}{l}-0.3562 * * * \\
(-4.28)\end{array}$ \\
\hline TTM & $\begin{array}{l}0.0287 \\
(1.03)\end{array}$ & $\begin{array}{l}0.0280 \\
(0.99)\end{array}$ & $\begin{array}{l}0.0016 \\
(0.03)\end{array}$ & \\
\hline Issue size & $\begin{array}{l}0.0096 * * * \\
(9.27)\end{array}$ & $\begin{array}{l}0.0086^{* * * *} \\
(6.45)\end{array}$ & $\begin{array}{l}0.0070 * * \\
(2.34)\end{array}$ & \\
\hline Year Fixed Effects & Yes & Yes & Yes & Yes \\
\hline Industry Fixed Effects & Yes & Yes & Yes & Yes \\
\hline Adj. $R^{2} /$ Pseudo $R^{2}$ & 0.74 & 0.64 & 0.34 & 0.23 \\
\hline \# Observations & 2,068 & 2,119 & 2,242 & 6,420 \\
\hline
\end{tabular}

$* * * \mathrm{p}<0.01, * * \mathrm{p}<0.05, * \mathrm{p}<0.1$ 
The results in Table 3.7 do not lend support to the hypothesized relation. The coefficients of the interaction variables are statistically insignificant in nearly all cases, which gives rise to the conclusion that there is no incremental effect of environmental management performance on the credit standing of inherently risky firms. ${ }^{23}$

An alternative explanation for the observed outcome is provided by earlier studies that point to the presence of considerable heterogeneity among environmentally risky industries (Cormier and Magnan, 1997; Schneider, 2010). Since HighRisk fails to take account of this heterogeneity, the interaction terms may inaccurately identify the predicted empirical relations. To test for this possibility, we separately analyze the two high-risk industries with the most available sample observations: the paper and allied products industry (19 firms), and the chemicals and allied products industry (40 firms). ${ }^{24} \mathrm{We}$ respectively create two new interaction variables that either combine our environmental performance measures with an indicator variable for the paper and allied products industry, $P \& A$; or chemicals and allied products industry, $C \& A$. The regression results for the paper and allied products industry are reported in Table 3.8.

In line with the existing evidence (Cormier and Magnan, 1997; Schneider, 2010), we find that the credit market is particular sensitive to the environmental concerns of firms in the paper and allied products industry. The coefficients on the interaction variable $E N V_{\text {Concerns }} * P \& A$ are both economically and statistically significant across regression models. The cost of debt regressions suggest that credit rating agencies consider industry-specific risks other than but correlated with the factors comprised in $E N V_{\text {Concerns }}$, since the respective interaction term only assumes the predicted sign after excluding BRmod. Given that $E N V_{\text {Concerns }}$ partially incorporates the same information sources as previous studies, these findings may in themselves not be surprising. Perhaps more interestingly, the coefficients on $E N V_{\text {Strengths }}{ }^{*} P \& A$ are in general economically and statistically significant, which implies that activities aimed at reducing environmental risk exposure improve the credit standing of firms in this high-risk industry. The basic environmental performance measures have their predicted signs and remain generally significant.

The regression results for the chemicals and allied products industry are less conclusive. ${ }^{25}$ While the outcomes for the basic environmental performance measures are very similar to those in the preceding analyses, we find no consistent evidence on an incremental effect for chemical firms. Altogether, our findings correspond with earlier conjectures that environmentally risky industries are fairly heterogeneous, and one should exercise care when pooling them for analysis. The outcomes for the tested industries may be explained by the varying degree of homogeneity among firms in both industries. Business operations in the paper and allied products industry are arguably more homogenous than that of firms in the chemicals and allied products industry (Schneider, 2010).

\footnotetext{
${ }^{23}$ An analysis of a more comprehensive set of risky industries produces very similar results. This extended set adds the following sectors to HighRisk: printing, publishing, and allied industries (2700); rubber and miscellaneous plastics products (3000); electronic and other electric equipment (3600); miscellaneous manufacturing industries (3900); textile mill products (2200); industrial machinery and equipment (5084); and lumber and wood products - except furniture (2400). We also test our general regression models on the sample subsets, and find that $E N V_{\text {Strengths }}$ and $E N V_{\text {Concerns }}$ generally load consistent with our main results.

${ }^{24}$ The complementary issuer ratings analysis covers 27 firms in the paper and allied products industry, and 84 firms in the chemicals and allied products industry, respectively.

${ }^{25}$ The respective regression results are excluded for brevity, but readily available from the authors on request.
} 
TABLE 3.8

\section{Environmental performance and credit risk: Pulp \& allied products industry}

This table reports on the effect of environmental management performance on credit risk for firms that operate in the environmental risky paper and allied products sector. We regress the cost of debt and credit ratings on measures of environmental management performance $\left(E N V_{\text {Strengths }}\right.$, $\left.E N V_{\text {Concerns }}\right)$ and respective interaction terms $\left(E N V_{\text {Strengths }} * P \& A, E N V_{\text {Concerns }} * P \& A\right)$, while controlling for issuer and issue specific control variables. $P \& A$ is an indicator variable that equals one if a firm operates in the paper and allied products sector, and otherwise zero. All models control for year fixed effects, and estimate standard errors that are clustered at the industry level (2-digit SIC code). Robust $t$-statistics are reported in parentheses below the coefficients.

\begin{tabular}{|c|c|c|c|c|}
\hline & $\ln ($ Spread $)$ & $\ln ($ Spread $)$ & Bond Rating & Issuer Rating \\
\hline $\mathrm{ENV}_{\text {Strengths }}$ & $\begin{array}{l}-0.0761 * * * \\
(-4.64)\end{array}$ & $\begin{array}{l}-0.0285 \\
(-1.24)\end{array}$ & $\begin{array}{l}0.1616^{*} \\
(1.76)\end{array}$ & $\begin{array}{l}0.0709 \\
(1.28)\end{array}$ \\
\hline $\mathrm{ENV}_{\text {Concerns }}$ & $\begin{array}{l}0.0421 * * * \\
(3.31)\end{array}$ & $\begin{array}{l}0.0437 * * \\
(2.31)\end{array}$ & $\begin{array}{l}-0.1522 * \\
(-1.70)\end{array}$ & $\begin{array}{l}-0.1334 * \\
(-1.81)\end{array}$ \\
\hline $\mathrm{ENV}_{\text {Strengths }} * \mathrm{P} \& \mathrm{~A}$ & $\begin{array}{l}-0.1330 * * * \\
(-7.37)\end{array}$ & $\begin{array}{l}-0.1464 * * * \\
(-5.41)\end{array}$ & $\begin{array}{l}0.0692 \\
(0.72)\end{array}$ & $\begin{array}{l}0.1210^{*} \\
(1.82)\end{array}$ \\
\hline $\mathrm{ENV}_{\text {Concerns }} * \mathrm{P} \& \mathrm{~A}$ & $\begin{array}{l}-0.0291 * \\
(-1.91)\end{array}$ & $\begin{array}{l}0.0557 * * * \\
(2.57)\end{array}$ & $\begin{array}{l}-0.6163 * * * \\
(-4.74)\end{array}$ & $\begin{array}{l}-0.2354 * * * \\
(-2.72)\end{array}$ \\
\hline P\&A & $\begin{array}{l}-1.0938 * * * \\
(-15.62)\end{array}$ & $\begin{array}{l}-1.2937 * * * \\
(-25.55)\end{array}$ & $\begin{array}{l}1.0499 * * * \\
(5.51)\end{array}$ & $\begin{array}{l}-0.4527 * * \\
(-2.14)\end{array}$ \\
\hline Brmod & $\begin{array}{l}-0.3273 * * * \\
(-13.96)\end{array}$ & & & \\
\hline Leverage & $\begin{array}{l}0.0031 * * \\
(2.51)\end{array}$ & $\begin{array}{l}0.0057 * * * \\
(3.61)\end{array}$ & $\begin{array}{l}-0.0168 * * * \\
(-3.87)\end{array}$ & $\begin{array}{l}-0.0104 * * * \\
(-3.69)\end{array}$ \\
\hline Size & $\begin{array}{l}-0.0690 * * * \\
(-3.89)\end{array}$ & $\begin{array}{l}-0.1777 * * * \\
(-11.72)\end{array}$ & $\begin{array}{l}0.6238 * * * \\
(5.85)\end{array}$ & $\begin{array}{l}0.5593 * * * \\
(10.05)\end{array}$ \\
\hline Capital Intensity & $\begin{array}{l}-0.0001 \\
(-0.18)\end{array}$ & $\begin{array}{l}-0.0015 * * \\
(-2.30)\end{array}$ & $\begin{array}{l}0.0071 * * * \\
(3.24)\end{array}$ & $\begin{array}{l}0.0046^{* * * *} \\
(3.47)\end{array}$ \\
\hline Interest Coverage & $\begin{array}{l}-0.0024 \\
(-1.08)\end{array}$ & $\begin{array}{l}-0.0078 * * \\
(-2.42)\end{array}$ & $\begin{array}{l}0.0327 * * \\
(2.32)\end{array}$ & $\begin{array}{l}0.0007 \\
(0.52)\end{array}$ \\
\hline ROA & $\begin{array}{l}-0.0162 * * * \\
(-5.31)\end{array}$ & $\begin{array}{l}-0.0284 * * * \\
(-5.66)\end{array}$ & $\begin{array}{l}0.0731 * * * \\
(4.16)\end{array}$ & $\begin{array}{l}0.0566^{* * * *} \\
(10.84)\end{array}$ \\
\hline Loss & $\begin{array}{l}0.1150 \\
(1.64)\end{array}$ & $\begin{array}{l}0.2889 * * * \\
(6.68)\end{array}$ & $\begin{array}{l}-1.0205 * * * \\
(-4.34)\end{array}$ & $\begin{array}{l}-0.3901 * * * \\
(-5.40)\end{array}$ \\
\hline Subordinated & $\begin{array}{l}0.2013 \text { *** } \\
(2.89)\end{array}$ & $\begin{array}{l}0.4778 * * * \\
(4.50)\end{array}$ & $\begin{array}{l}-1.2986 * * * \\
(-4.45)\end{array}$ & $\begin{array}{l}-0.3598 * * * \\
(-4.30)\end{array}$ \\
\hline Issue size & $\begin{array}{l}0.0095^{* * * *} \\
(9.22)\end{array}$ & $\begin{array}{l}0.0086^{* * * *} \\
(6.42)\end{array}$ & $\begin{array}{l}0.0068 * * \\
(2.28)\end{array}$ & \\
\hline TTM & $\begin{array}{l}0.0288 \\
(1.03)\end{array}$ & $\begin{array}{l}0.0287 \\
(1.02)\end{array}$ & $\begin{array}{l}-0.0007 \\
(-0.01)\end{array}$ & \\
\hline Year Fixed Effects & Yes & Yes & Yes & Yes \\
\hline Industry Fixed Effects & Yes & Yes & Yes & Yes \\
\hline Adj. R² / Pseudo R & 0.74 & 0.64 & 0.34 & 0.23 \\
\hline \# Observations & 2,068 & 2,119 & 2,242 & 6,420 \\
\hline
\end{tabular}

$* * * \mathrm{p}<0.01, * * \mathrm{p}<0.05, * \mathrm{p}<0.1$ 


\subsubsection{Change in the relevance of environmental management over time}

We argue that the relevance of corporate environmental management has increased over the recent years, as a result of the growing climate change concerns and investors' awareness of the associated regulatory risks. To test this hypothesis for bond investors, we split our sample into two periods from 1995-2001 and 2002-2006, and repeat our main analyses for both subperiods. Our selection is motivated by the distinction between the pre and post dot-com bubble periods. During the boom phase of the IT economy, environmental concerns are expected to have played a subordinated role in financial markets. In contrast, the subsequent period includes or follows shortly after a number of influential climate change initiative and publications that drew considerable attention to the issue.

Table 3.9 summarizes the credit risk effect of environmental management over time. Panel A reports on regression results for the period from 1995 to 2001, and Panel B on those for the period from 2002 to 2006 . For brevity, we do not show the coefficients on the control variables.

The results suggest that the relevance of environmental management for credit risk has indeed increased over time, and that this increase is mainly attributable to impact of environmental concerns. Panel A only shows a significant relation for $E N V_{\text {Strengths }}$ in the cost of debt regression, which supports the view that the credit market only assigned little value to corporate environmental concerns prior to the dot-com bubble. The subsequent period reports significant factor loadings on $E N V_{\text {Concerns }}$ across all credit models, which corresponds with the hypothesis that investors are increasingly concerned about the financial implications of climate change.

TABLE 3.9

\section{Credit risk implications of environmental management over time}

This table shows the effect of environmental management performance on credit risk over different time periods. We split our sample into two periods: Panel A summarizes regression results for the 1995 to 2001 period. Panel B reports the respective regression results for the period from 2002 to 2006. All regression results are based on the comprehensive model specifications, while we do not report on the control variables for brevity. We control for year and industry fixed effects (2-digit SIC codes), and estimate standard errors that are clustered at the industry level (2-digit SIC code). Robust $t$-statistics are reported in parentheses below the coefficients.

PANel A: 1995-2001 period

\begin{tabular}{llll}
\hline \hline & ln(Spread) & Bond Rating & Issuer Rating \\
\hline ENV $_{\text {Strengths }}$ & $-0.1266^{* * *}$ & 0.2105 & 0.0571 \\
& $(-2.87)$ & $(1.28)$ & $(0.71)$ \\
ENV $_{\text {Concerns }}$ & -0.0084 & -0.1479 & -0.0794 \\
& $(-0.29)$ & $(-1.42)$ & $(-0.87)$ \\
Year Fixed Effects & Yes & Yes & Yes \\
Industry Fixed Effects & Yes & Yes & Yes \\
Adj. R ${ }^{2}$ / Pseudo R & & & 0.33 \\
\# Observations & 0.52 & 1,195 & 2,323 \\
\hline
\end{tabular}

$* * * \mathrm{p}<0.01, * * \mathrm{p}<0.05, * \mathrm{p}<0.1$ 
PANEL B: 2002-2006 period

\begin{tabular}{llll}
\hline \hline & ln(Spread) & Bond Rating & Issuer Rating \\
\hline ENV $_{\text {Strengths }}$ & $-0.0251^{*}$ & 0.1480 & 0.0651 \\
& $(-1.70)$ & $(0.98)$ & $(0.77)$ \\
ENV $_{\text {Concerns }}$ & $0.0852^{* * *}$ & $-0.2285^{* *}$ & $-0.2147^{* * *}$ \\
& $(3.99)$ & $(-2.34)$ & $(-3.86)$ \\
Year Fixed Effects & Yes & Yes & Yes \\
Industry Fixed Effects & Yes & Yes & Yes \\
Adj. R $\mathbf{R}^{2}$ Pseudo R & & & 0.26 \\
\# Observations & 0.68 & 1,047 & 4,097 \\
\hline
\end{tabular}

*** $\mathrm{p}<0.01, * * \mathrm{p}<0.05, * \mathrm{p}<0.1$

$E N V_{\text {Strengths }}$ continues to only load significantly in the cost of debt regression, although its economical and statistical significance diminish. From 2002 to 2006, a standard deviation increase in $E N V_{\text {Strengths }}$ corresponded with a reduction in the yield spread by 5 basis points, whereas a standard deviation increase in $E N V_{\text {Concerns }}$ was associated with an increase in the yield spread by 10 basis points.

\subsubsection{Robustness checks}

\subsubsection{Aggregate environmental management performance}

Our analysis up to this point focuses on environmental management strengths and concerns as separate constructs. This approach differs from most of the earlier studies that rely on data from KLD, and combine both groups of performance indicators to construct aggregate performance measures (see, e.g., Graves and Waddock, 1994; Waddock and Graves, 1997; Johnson and Greening, 1999; Kane et al., 2005; Fisman et al., 2006; Kempf and Osthoff, 2007; and Statman and Glushkov, 2009). To consider this alternative, we calculate a measure for the firm's aggregate environmental performance, $E N V_{\text {Total }}$, by subtracting $E N V_{\text {Concerns }}$ from $E N V_{\text {Strengths. }}$ A higher score on $E N V_{\text {Total }}$ suggests that a firm displays a better general environmental performance, and vice versa. We repeat our main analyses using the aggregate performance measure, and summarize the outcomes in Table 3.10.

The regression results closely align with our earlier findings: $E N V_{\text {Total }}$ has a statistically significant coefficient in all credit risk models, and the signs suggest that a better general environmental performance is associated with an enhanced credit standing of the firm.

\subsubsection{Ordinary yield spread}

We log-transform our measure for the cost of debt financing, $\ln ($ Spread), to account for the considerable skewness in yield spreads. To verify that our results are not sensitive to this adjustment, we repeat our cost of debt analysis using the ordinary yield spread, Spread. 


\section{TABLE 3.10}

\section{Aggregate environmental performance and credit risk}

This table presents regression results for the effect of firms' aggregate environmental management performance $\left(E N V_{\text {Total }}\right)$ on measures of their credit risk. We implement pooled OLS regressions for the cost of debt, and ordered probit models for the credit ratings. All models include year and industry fixed effects (2-digit SIC codes). Standard errors are clustered at the industry level (2-digit SIC codes). Robust $t$-statistics are reported in parentheses below the coefficients.

\begin{tabular}{llll}
\hline \hline & ln(Spread $)$ & Bond Rating & Issuer Rating \\
\hline ENV $_{\text {Total }}$ & $-0.0459^{* * *}$ & $0.1826^{* *}$ & $0.1239^{* * *}$ \\
& $(-5.39)$ & $(2.55)$ & $(2.85)$ \\
Brmod & $-0.3257^{* * *}$ & & \\
& $(-14.13)$ & & \\
Leverage & $0.0031^{* *}$ & $-0.0165^{* * *}$ & $-0.0104^{* * *}$ \\
Size & $(2.52)$ & $(-3.90)$ & $(-3.69)$ \\
& $-0.0712^{* * *}$ & $0.6112^{* * *}$ & $0.5485^{* * *}$ \\
Capital Intensity & $(-4.02)$ & $(5.79)$ & $(9.10)$ \\
& -0.0002 & $0.0068^{* * *}$ & $0.0044^{* * *}$ \\
Interest Coverage & $(-0.23)$ & $(3.20)$ & $(3.44)$ \\
& -0.0025 & 0.0323 & 0.0007 \\
ROA & $(-1.10)$ & $(2.33)$ & $(0.53)$ \\
& $-0.0159^{* * *}$ & $0.0747^{* * *}$ & $0.0566^{* * *}$ \\
Loss & $(-5.13)$ & $(4.22)$ & $(10.81)$ \\
Subordinated & $0.1204^{*}$ & $-0.9851^{* * *}$ & $-0.3885^{* * *}$ \\
TTM & $(1.67)$ & $(-4.03)$ & $(-5.37)$ \\
Issue size & $0.2006^{* * *}$ & $-1.2932^{* * *}$ & $-0.3517^{* * *}$ \\
& $(2.89)$ & $(-4.45)$ & $(-4.17)$ \\
Year Fixed Effects & $0.0096^{* * *}$ & $0.0067^{* * *}$ & \\
Industry Fixed Effects & $(9.32)$ & $(2.29)$ & \\
Adj. R & 0.0302 & 0.0005 & \\
\# Observations & $(1.07)$ & $(0.01)$ & \\
\hline
\end{tabular}

$* * * \mathrm{p}<0.01, * * \mathrm{p}<0.05, * \mathrm{p}<0.1$

Table 3.11 shows that the regression outcomes are very similar to those for $\ln (\operatorname{Spread})$. The coefficients on the environmental performance measures are statistically significant, and their economic magnitude comparable in size: A one standard deviation change in $E N V_{\text {Strengths }}$ corresponds with a 7 basis point reduction in the cost of debt; and a one standard deviation change in $E N V_{\text {Concerns }}$ is associated with a 6 basis point increase in the cost of debt. 


\section{TABLE 3.11}

\section{Cost of debt regressions: Ordinary yield spreads}

This table shows the effect of environmental management performance on the cost of debt financing, using ordinary yield spreads (Spread). We regress Spread on measures of environmental management performance $\left(E N V_{\text {Strengths, }} E N V_{\text {Concerns }}, E N V_{\text {Total }}\right)$, and an array of issuer and issue control variables. The general model is extended with a modified bond rating variable (BRmod) that is orthogonal to the environmental performance measures, to account for credit relevant information that is not captured by our control variables but incorporated by credit rating agencies. All models include year and industry fixed effects (2-digit SIC codes), and estimate standard errors that are clustered at the industry level (2-digit SIC codes). Robust $t$-statistics are reported in parentheses below the coefficients.

\begin{tabular}{|c|c|c|c|c|}
\hline & (I.b) & (I.c) & (II.b) & (II.c) \\
\hline $\mathrm{ENV}_{\text {Strengths }}$ & $\begin{array}{l}-5.05 \\
(-1.29)\end{array}$ & $\begin{array}{l}-11.81 \text { *** } \\
(-3.50)\end{array}$ & & \\
\hline $\mathrm{ENV}_{\text {Concerns }}$ & $\begin{array}{l}8.00 * * * \\
(3.03)\end{array}$ & $\begin{array}{l}5.94 * * * \\
(3.04)\end{array}$ & & \\
\hline $\mathrm{ENV}_{\text {Concerns }}$ & & & $\begin{array}{l}-7.06 * * * \\
(-3.79)\end{array}$ & $\begin{array}{l}-6.68 * * * \\
(-4.23)\end{array}$ \\
\hline BRmod & & $\begin{array}{l}-50.86 * * * \\
(-10.33)\end{array}$ & & $\begin{array}{l}-50.85 * * * \\
(-10.25)\end{array}$ \\
\hline Leverage & $\begin{array}{l}0.66^{* * *} \\
(3.33)\end{array}$ & $\begin{array}{l}0.64 * * * \\
(2.65)\end{array}$ & $\begin{array}{l}0.66^{* * * *} \\
(3.34)\end{array}$ & $\begin{array}{l}0.64 * * * \\
(2.65)\end{array}$ \\
\hline Size & $\begin{array}{l}-20.51 * * * \\
(-9.05)\end{array}$ & $\begin{array}{l}-10.70^{* * * *} \\
(-3.83)\end{array}$ & $\begin{array}{l}-20.01 * * * \\
(-8.96)\end{array}$ & $\begin{array}{l}-10.78^{* * * *} \\
(-3.66)\end{array}$ \\
\hline Capital Intensity & $\begin{array}{l}-0.14 \\
(-1.20)\end{array}$ & $\begin{array}{l}-0.01 \\
(-0.03)\end{array}$ & $\begin{array}{l}-0.13 \\
(-1.12)\end{array}$ & $\begin{array}{l}-0.01 \\
(-0.04)\end{array}$ \\
\hline Interest Coverage & $\begin{array}{l}-0.16 \\
(-0.42)\end{array}$ & $\begin{array}{l}0.38 \\
(0.92)\end{array}$ & $\begin{array}{l}-0.17 \\
(-0.44)\end{array}$ & $\begin{array}{l}0.38 \\
(0.91)\end{array}$ \\
\hline ROA & $\begin{array}{l}-4.49 * * * \\
(-6.05)\end{array}$ & $\begin{array}{l}-3.39 * * * \\
(-4.14)\end{array}$ & $\begin{array}{l}-4.50 * * * \\
(-6.08)\end{array}$ & $\begin{array}{l}-3.39 * * * \\
(-4.15)\end{array}$ \\
\hline Loss & $\begin{array}{l}56.61 * * * \\
(3.76)\end{array}$ & $\begin{array}{l}58.29 * * * \\
(2.82)\end{array}$ & $\begin{array}{l}56.97 * * * \\
(3.76)\end{array}$ & $\begin{array}{l}58.24 * * * \\
(2.80)\end{array}$ \\
\hline Subordinated & $\begin{array}{l}84.52 * * * \\
(3.52)\end{array}$ & $\begin{array}{l}96.03 * * * \\
(3.88)\end{array}$ & $\begin{array}{l}84.65 * * * \\
(3.50)\end{array}$ & $\begin{array}{l}96.02 * * * \\
(3.88)\end{array}$ \\
\hline TTM & $\begin{array}{l}0.98 * * * \\
(7.52)\end{array}$ & $\begin{array}{l}0.92 * * * \\
(7.97)\end{array}$ & $\begin{array}{l}0.99 * * * \\
(7.70)\end{array}$ & $\begin{array}{l}0.92 * * * \\
(8.12)\end{array}$ \\
\hline Issue size & $\begin{array}{l}1.62 \\
(0.42)\end{array}$ & $\begin{array}{l}3.92 \\
(1.09)\end{array}$ & $\begin{array}{l}1.55 \\
(0.39)\end{array}$ & $\begin{array}{l}3.93 \\
(1.09)\end{array}$ \\
\hline Speculative & $\begin{array}{l}121.68^{* * *} \\
(11.69)\end{array}$ & & $\begin{array}{l}121.66^{* * * *} \\
(11.60)\end{array}$ & \\
\hline Year Fixed Effects & Yes & Yes & & Yes \\
\hline Industry Fixed Effects & Yes & Yes & & Yes \\
\hline Adj. $R^{2}$ & 0.62 & 0.61 & 0.62 & 0.61 \\
\hline \# Observations & 2,148 & 2,093 & 2,148 & 2,093 \\
\hline
\end{tabular}




\subsubsection{Marginal effects analysis for credit ratings}

Interpreting the ordered probit coefficients in the credit ratings analyses is unfortunately not straightforward: While the factor loadings enable us to infer the odds of being assigned into a higher (or lower) credit rating category given a change in an independent variable, they do not provide information on how the effect is distributed across the different credit rating categories. More specifically, judging only by the sign of the coefficient, it is not possible to infer whether the signs of the marginal effects are internally consistent. To enhance our understanding of the link between environmental management information and credit ratings, we complement our ordered probit regressions with marginal effects analyses. The marginal effects predict how a change in a variable translates into the probability of observing a particular bond rating outcome, while holding the other explanatory variables fixed at their mean. Table 3.12 reports results for our bond rating analysis:

\section{TABLE 3.12}

\section{Marginal effects analysis: Bond ratings}

This table reports the marginal effects for the bond rating analysis. The marginal effects estimate the probability of a firm being ranked in a particular bond rating category (AAA, AA, AA, BBB, BB, B, or CCC-D) given a change in an explanatory variable, while holding the explanatory variables fixed at their mean. $\mathrm{T}$-statistics are reported in parentheses below the coefficients.

\begin{tabular}{|c|c|c|c|c|c|c|c|}
\hline & CCC-D & B & BB & BBB & $\mathbf{A}$ & $\mathbf{A A}$ & $\mathbf{A A A}$ \\
\hline $\mathrm{ENV}_{\text {Strengths }}$ & $\begin{array}{l}0.0000 \\
(-0.54)\end{array}$ & $\begin{array}{l}-0.0004 \\
(-1.18)\end{array}$ & $\begin{array}{l}-0.0106^{*} \\
(-1.87)\end{array}$ & $\begin{array}{l}-0.0526^{*} \\
(-1.92)\end{array}$ & $\begin{array}{l}0.0585^{*} \\
(1.94)\end{array}$ & $\begin{array}{l}0.0050 \\
(1.63)\end{array}$ & $\begin{array}{l}0.0001 \\
(0.79)\end{array}$ \\
\hline $\mathrm{ENV}_{\text {Concerns }}$ & $\begin{array}{l}0.0000 \\
(0.54)\end{array}$ & $\begin{array}{l}0.0004 \\
(1.12)\end{array}$ & $\begin{array}{l}0.0126^{* * *} \\
(2.00)\end{array}$ & $\begin{array}{l}0.0625^{* *} \\
(2.18)\end{array}$ & $\begin{array}{l}-0.0695^{* *} \\
(-2.20)\end{array}$ & $\begin{array}{l}-0.0060 * \\
(-1.72)\end{array}$ & $\begin{array}{l}-0.0001 \\
(-0.86)\end{array}$ \\
\hline Leverage & $\begin{array}{l}0.0000 \\
(0.63)\end{array}$ & $\begin{array}{l}0.0000 * \\
(1.67)\end{array}$ & $\begin{array}{l}0.0011 * * * \\
(3.51)\end{array}$ & $\begin{array}{l}0.0053 * * * \\
(3.73)\end{array}$ & $\begin{array}{l}-0.0059 * * * \\
(-3.77)\end{array}$ & $\begin{array}{l}-0.0005^{* * *} \\
(-3.22)\end{array}$ & $\begin{array}{l}0.0000 \\
(-0.94)\end{array}$ \\
\hline Size & $\begin{array}{l}0.0000 \\
(-0.66)\end{array}$ & $\begin{array}{l}-0.0013 * \\
(-1.66)\end{array}$ & $\begin{array}{l}-0.0403 * * * \\
(-5.40)\end{array}$ & $\begin{array}{l}-0.2001 * * * \\
(-5.29)\end{array}$ & $\begin{array}{l}0.2224 * * * \\
(5.47)\end{array}$ & $\begin{array}{l}0.0191 * * * \\
(4.50)\end{array}$ & $\begin{array}{l}0.0002 \\
(0.96)\end{array}$ \\
\hline Capital Intensity & $\begin{array}{l}0.0000 \\
(-0.60)\end{array}$ & $\begin{array}{l}0.0000 \\
(-1.43)\end{array}$ & $\begin{array}{l}-0.0005^{* * *} \\
(-3.47)\end{array}$ & $\begin{array}{l}-0.0023 * * * \\
(-3.02)\end{array}$ & $\begin{array}{l}0.0025 * * * \\
(3.15)\end{array}$ & $\begin{array}{l}0.0002 * * \\
(2.57)\end{array}$ & $\begin{array}{l}0.0000 \\
(1.05)\end{array}$ \\
\hline Interest Coverage & $\begin{array}{l}0.0000 \\
(-0.63)\end{array}$ & $\begin{array}{l}-0.0001 * \\
(-1.71)\end{array}$ & $\begin{array}{l}-0.0021^{* *} \\
(-2.47)\end{array}$ & $\begin{array}{l}-0.0105^{* *} \\
(-2.22)\end{array}$ & $\begin{array}{l}0.0116^{* *} \\
(2.25)\end{array}$ & $\begin{array}{l}0.0010 * * \\
(2.56)\end{array}$ & $\begin{array}{l}0.0000 \\
(0.92)\end{array}$ \\
\hline ROA & $\begin{array}{l}0.0000 \\
(-0.63)\end{array}$ & $\begin{array}{l}-0.0002 \\
(-1.37)\end{array}$ & $\begin{array}{l}-0.0049 * * * \\
(-3.47)\end{array}$ & $\begin{array}{l}-0.0242 * * * \\
(-4.11)\end{array}$ & $\begin{array}{l}0.0269 * * * \\
(4.17)\end{array}$ & $\begin{array}{l}0.0023 * * * \\
(2.83)\end{array}$ & $\begin{array}{l}0.0000 \\
(0.91)\end{array}$ \\
\hline $\operatorname{Loss}^{+}$ & $\begin{array}{l}0.0001 \\
(0.52)\end{array}$ & $\begin{array}{l}0.0107 \\
(1.12)\end{array}$ & $\begin{array}{l}0.1366^{* *} \\
(2.43)\end{array}$ & $\begin{array}{l}0.1633 * * * \\
(7.98)\end{array}$ & $\begin{array}{l}-0.2983 * * * \\
(-5.98)\end{array}$ & $\begin{array}{l}-0.0123 * * * \\
(-2.97)\end{array}$ & $\begin{array}{l}-0.0001 \\
(-0.86)\end{array}$ \\
\hline Subordinated $^{+}$ & $\begin{array}{l}0.0003 \\
(0.64)\end{array}$ & $\begin{array}{l}0.0239 \\
(1.17)\end{array}$ & $\begin{array}{l}0.2151 * * \\
(2.53)\end{array}$ & $\begin{array}{l}0.1253 * * \\
(2.03)\end{array}$ & $\begin{array}{l}-0.3517 * * * \\
(-8.06)\end{array}$ & $\begin{array}{l}-0.0127 * * * \\
(-3.12)\end{array}$ & $\begin{array}{l}-0.0001 \\
(-0.85)\end{array}$ \\
\hline Time-to-maturity & $\begin{array}{l}0.0000 \\
(-0.55)\end{array}$ & $\begin{array}{l}0.0000 \\
(-1.15)\end{array}$ & $\begin{array}{l}-0.0004 * * \\
(-1.97)\end{array}$ & $\begin{array}{l}-0.0022 * * \\
(-2.34)\end{array}$ & $\begin{array}{l}0.0025^{* *} \\
(2.35)\end{array}$ & $\begin{array}{l}0.0002 * \\
(1.65)\end{array}$ & $\begin{array}{l}0.0000 \\
(0.89)\end{array}$ \\
\hline Issue size & $\begin{array}{l}0.0000 \\
(0.00)\end{array}$ & $\begin{array}{l}0.0000 \\
(0.00)\end{array}$ & $\begin{array}{l}0.0000 \\
(0.00)\end{array}$ & $\begin{array}{l}-0.0001 \\
(0.00)\end{array}$ & $\begin{array}{l}0.0001 \\
(0.00)\end{array}$ & $\begin{array}{l}0.0000 \\
(0.00)\end{array}$ & $\begin{array}{l}0.0000 \\
(0.00)\end{array}$ \\
\hline
\end{tabular}

$* * * \mathrm{p}<0.01, * * \mathrm{p}<0.05, * \mathrm{p}<0.1$

${ }^{+} d y / d x$ is for discrete change of dummy variable from 0 to 1 
The marginal effects show that an increase in $E N V_{\text {Strengths }}$ significantly decreases the probability of receiving a bond rating of "BBB" or lower, while increasing the probability of being rated "A" or higher. By contrast, an increase in $E N V_{\text {Concerns }}$ significantly decreases the probability of being rated " $\mathrm{A}$ " or higher, and increases the probability of receiving a rating of "BBB" or lower.

Table 3.13 reports marginal effects for the issuer rating analysis, which are generally consistent with those of the bond ratings. A change in ENVConcerns significantly decreases the firm's probability of receiving a long-term issuer rating of "BBB" or higher, while increasing the probability of being rated "BB" or lower.

Taken as a whole, the marginal effects lend support to our earlier conclusions on the ordered probit regressions. Environmental management performance, and especially corporate activities that increase environmental risks, are significantly and consistently associated with the credit ratings of firms.

\section{TABLE 3.13}

\section{Marginal effects analysis: Issuer ratings}

This table reports the marginal effects for the issuer rating analysis. The marginal effects estimate the probability of a firm being ranked in a particular bond rating category (AAA, AA, AA, BBB, BB, B, or CCC-D) given a change in an explanatory variable, while holding the explanatory variables fixed at their mean. T-statistics are reported in parentheses below the coefficients.

\begin{tabular}{|c|c|c|c|c|c|c|c|}
\hline & CCC-D & B & BB & BBB & A & $\mathbf{A A}$ & AAAA \\
\hline $\mathrm{ENV}_{\text {Strengths }}$ & $\begin{array}{l}0.0000 \\
(-1.31)\end{array}$ & $\begin{array}{l}-0.0105 \\
(-1.50)\end{array}$ & $\begin{array}{l}-0.0180 \\
(-1.45)\end{array}$ & $\begin{array}{l}0.0089 \\
(1.38)\end{array}$ & $\begin{array}{l}0.0183 \\
(1.52)\end{array}$ & $\begin{array}{l}0.0013 \\
(1.31)\end{array}$ & $\begin{array}{l}0.0001 \\
(1.23)\end{array}$ \\
\hline $\mathrm{ENV}_{\text {Concerns }}$ & $\begin{array}{l}0.0001 \\
(1.06)\end{array}$ & $\begin{array}{l}0.0206^{*} \\
(1.89)\end{array}$ & $\begin{array}{l}0.0353^{* *} \\
(2.18)\end{array}$ & $\begin{array}{l}-0.0175^{* * *} \\
(-2.15)\end{array}$ & $\begin{array}{l}-0.0358^{* *} \\
(-2.04)\end{array}$ & $\begin{array}{l}-0.0025 \\
(-1.63)\end{array}$ & $\begin{array}{l}-0.0002 \\
(-1.09)\end{array}$ \\
\hline Leverage & $\begin{array}{l}0.0000 \\
(1.29)\end{array}$ & $\begin{array}{l}0.0015^{* * *} \\
(3.69)\end{array}$ & $\begin{array}{l}0.0025 * * * \\
(3.47)\end{array}$ & $\begin{array}{l}-0.0012 * * * \\
(-3.18)\end{array}$ & $\begin{array}{l}-0.0025 * * * \\
(-3.75)\end{array}$ & $\begin{array}{l}-0.0002 * * * \\
(-2.64)\end{array}$ & $\begin{array}{l}0.0000 \\
(-1.52)\end{array}$ \\
\hline Size & $\begin{array}{l}-0.0004 \\
(-1.31)\end{array}$ & $\begin{array}{l}-0.0789 * * * \\
(-8.71)\end{array}$ & $\begin{array}{l}-0.1352 * * * \\
(-7.36)\end{array}$ & $\begin{array}{l}0.0670 * * * \\
(5.31)\end{array}$ & $\begin{array}{l}0.1369 * * * \\
(11.83)\end{array}$ & $\begin{array}{l}0.0096^{* * * *} \\
(3.24)\end{array}$ & $\begin{array}{l}0.0009 \\
(1.45)\end{array}$ \\
\hline Capital Intensity & $\begin{array}{l}0.0000 \\
(-1.10)\end{array}$ & $\begin{array}{l}-0.0006^{* * * *} \\
(-3.45)\end{array}$ & $\begin{array}{l}-0.0011 * * * \\
(-3.31)\end{array}$ & $\begin{array}{l}0.0005^{* * * *} \\
(3.19)\end{array}$ & $\begin{array}{l}0.0011 * * * \\
(3.43)\end{array}$ & $\begin{array}{l}0.0001^{* *} \\
(2.56)\end{array}$ & $\begin{array}{l}0.0000 \\
(1.26)\end{array}$ \\
\hline Interest Coverage & $\begin{array}{l}0.0000 \\
(-0.53)\end{array}$ & $\begin{array}{l}-0.0001 \\
(-0.50)\end{array}$ & $\begin{array}{l}-0.0002 \\
(-0.51)\end{array}$ & $\begin{array}{l}0.0001 \\
(0.51)\end{array}$ & $\begin{array}{l}0.0002 \\
(0.51)\end{array}$ & $\begin{array}{l}0.0000 \\
(0.49)\end{array}$ & $\begin{array}{l}0.0000 \\
(0.44)\end{array}$ \\
\hline ROA & $\begin{array}{l}0.0000 \\
(-1.30)\end{array}$ & $\begin{array}{l}-0.0080^{* * *} \\
(-6.26)\end{array}$ & $\begin{array}{l}-0.0137 * * * \\
(-9.93)\end{array}$ & $\begin{array}{l}0.0068 * * * \\
(6.60)\end{array}$ & $\begin{array}{l}0.0139 * * * \\
(9.82)\end{array}$ & $\begin{array}{l}0.0010^{* * *} \\
(2.94)\end{array}$ & $\begin{array}{l}0.0001 \\
(1.40)\end{array}$ \\
\hline $\operatorname{Loss}^{+}$ & $\begin{array}{l}0.0005 \\
(1.13)\end{array}$ & $\begin{array}{l}0.0697 * * * \\
(4.85)\end{array}$ & $\begin{array}{l}0.0841 * * * \\
(5.06)\end{array}$ & $\begin{array}{l}-0.0669 * * * \\
(-3.93)\end{array}$ & $\begin{array}{l}-0.0824 * * * \\
(-5.97)\end{array}$ & $\begin{array}{l}-0.0046 * * * \\
(-3.31)\end{array}$ & $\begin{array}{l}-0.0004 \\
(-1.34)\end{array}$ \\
\hline Subordinated $^{+}$ & $\begin{array}{l}0.0004 \\
(1.22)\end{array}$ & $\begin{array}{l}0.0584 * * * \\
(3.79)\end{array}$ & $\begin{array}{l}0.0799 * * * \\
(4.17)\end{array}$ & $\begin{array}{l}-0.0545^{* * * *} \\
(-3.42)\end{array}$ & $\begin{array}{l}-0.0790 * * * \\
(-4.39)\end{array}$ & $\begin{array}{l}-0.0048^{* * *} \\
(-3.13)\end{array}$ & $\begin{array}{l}-0.0004 \\
(-1.47)\end{array}$ \\
\hline
\end{tabular}

$* * * \mathrm{p}<0.01, * * \mathrm{p}<0.05, * \mathrm{p}<0.1$

${ }^{+} d y / d x$ is for discrete change of dummy variable from 0 to 1 


\subsubsection{Credit relevance of environmental performance categories in more recent years}

Our preceding analysis suggests that corporate environmental management has become increasingly relevant for bond investors over the recent years. To identify which environmental activities drive the observed relations in the latter half of our sample period, we analyze their respective impact on credit risk during the years from 2002 to 2006. Table 3.14 summarizes the regression results.

The results are consistent with our earlier finding that the economic and statistical significance of environmental concerns has increased over recent years, while that for environmental engagement has diminished. The environmental activities that drive the credit risk relation continue to be the same as in our main analysis, although the previously significant Clean Energy and Other Strength categories only continue to be significant in the cost of debt analysis.

\subsubsection{Additional tests}

As an additional robustness check, we test the sensitivity of the main results to the clustering of standard errors at different levels (e.g., firm, year, industry and year), and confirm that our findings are robust to these modifications. Next, environmental performance studies in multiindustry settings generally face the concern that empirical outcomes may be driven by interindustry differences (e.g., Cormier and Magnan, 1997; Clarkson et al., 2004). We control for such industry effects by including 2-digit SIC code indicator variables into our analysis, while clustering the standard errors of the coefficients accordingly. To account for concerns about the low representation in some of the 2-digit SIC code industries, we repeat our analysis with industry fixed effects based on SIC division level codes. The significance of our findings slightly increases following this adjustment. 


\section{TABLE 3.14}

\section{Credit risk implications of environmental performance activities (2002-2006)}

This table summarizes the effect of individual environmental performance factors on credit risk during the period from 2002 to 2006. We decompose our measures of environmental management performance $\left(\mathrm{ENV}_{\mathrm{Strengths}}\right.$, $\left.\mathrm{ENV}_{\text {Concerns }}\right)$, and test the relation of their components with the cost of debt financing and credit ratings. To account for correlation within each of the performance measures, we orthogonalize the individual environmental activities with respect to each other. The control variables are not reported for brevity. All models control for year and industry fixed effects (2-digit SIC codes), and estimate standard errors that are clustered at the industry level (2digit SIC code). Robust $t$-statistics are reported in parentheses below the coefficients.

\begin{tabular}{|c|c|c|c|}
\hline & $\ln ($ Spread $)$ & Bond Rating & Issuer Rating \\
\hline \multicolumn{4}{|l|}{$\mathrm{ENV}_{\text {Strengths }}$} \\
\hline Beneficial Products & $\begin{array}{l}-0.0980 * * \\
(-2.23)\end{array}$ & $\begin{array}{l}-6.52 \\
(-0.47)\end{array}$ & $\begin{array}{l}0.2182 \\
(0.55)\end{array}$ \\
\hline Pollution Prevention & $\begin{array}{l}0.0279 \\
(0.32)\end{array}$ & $\begin{array}{l}10.24 \\
(0.64)\end{array}$ & $\begin{array}{l}0.3726 \\
(0.66)\end{array}$ \\
\hline Recycling & $\begin{array}{l}-0.0485 \\
(-0.47)\end{array}$ & $\begin{array}{l}-3.02 \\
(-0.15)\end{array}$ & $\begin{array}{l}-0.0831 \\
(-0.23)\end{array}$ \\
\hline Clean Energy & $\begin{array}{l}-0.0886 * * \\
(-2.35)\end{array}$ & $\begin{array}{l}-18.97 * * * \\
(-2.74)\end{array}$ & $\begin{array}{l}0.1408 \\
(0.67)\end{array}$ \\
\hline Other Strength & $\begin{array}{l}-0.2292 * * * \\
(-2.97)\end{array}$ & $\begin{array}{l}-29.05^{* *} \\
(-2.01)\end{array}$ & $\begin{array}{l}0.4299 \\
(1.47)\end{array}$ \\
\hline \multicolumn{4}{|l|}{$\mathrm{ENV}_{\text {Concerns }}$} \\
\hline Hazardous Waste & $\begin{array}{l}0.0671 \\
(0.99)\end{array}$ & $\begin{array}{l}9.00 \\
(0.76)\end{array}$ & $\begin{array}{l}-0.3009 \\
(-0.83)\end{array}$ \\
\hline Regulatory Problems & $\begin{array}{l}0.2009 * * * \\
(2.73)\end{array}$ & $\begin{array}{l}41.76 * * * \\
(3.51)\end{array}$ & $\begin{array}{l}-0.4808 \\
(-1.09)\end{array}$ \\
\hline Substantial Emissions & $\begin{array}{l}0.2274 * * * \\
(2.85)\end{array}$ & $\begin{array}{l}38.93 * * * \\
(2.73)\end{array}$ & $\begin{array}{l}-0.9263^{* *} \\
(-2.07)\end{array}$ \\
\hline Agricultural Chemicals & $\begin{array}{l}0.0466 \\
(0.80)\end{array}$ & $\begin{array}{l}-10.54 \\
(-0.79)\end{array}$ & $\begin{array}{l}-0.1232 \\
(-0.67)\end{array}$ \\
\hline Climate Change & $\begin{array}{l}0.2332 * * * \\
(3.09)\end{array}$ & $\begin{array}{l}56.29 * * * \\
(5.99)\end{array}$ & $\begin{array}{l}-0.7896^{* *} \\
(-1.99)\end{array}$ \\
\hline Other Concern & $\begin{array}{l}0.1291 \text { *** } \\
(2.47)\end{array}$ & $\begin{array}{l}9.93 \\
(1.01)\end{array}$ & $\begin{array}{l}-0.1122 \\
(-0.29)\end{array}$ \\
\hline Year Fixed Effects & Yes & Yes & Yes \\
\hline Industry Fixed Effects & Yes & Yes & Yes \\
\hline Adj. R² / Pseudo R ${ }^{2}$ & 0.74 & 0.53 & 0.37 \\
\hline \# Observations & 963 & 984 & 1,674 \\
\hline
\end{tabular}

$* * * \mathrm{p}<0.01, * * \mathrm{p}<0.05, * \mathrm{p}<0.1$ 


\subsection{Conclusion}

This paper presents comprehensive evidence that the environmental management of public corporations has credit risk implications for bond investors. The fundamental hypothesis underlying our analysis is that environmental practices affect the solvency of borrowing firms, by determining their exposure to potentially costly legal, reputational, and regulatory risks. We construct aggregate measures for the environmental strengths and concerns of firms, and test their relation with the yield spread of newly issued bonds, bond ratings, and long-term issuer ratings.

Our analysis shows that firms with environmental concerns pay a premium on the cost of debt financing and have lower credit ratings assigned to them. The corporate activities that underlie this relation are mainly related to regulatory and climate change issues. In contrast, firms with a proactive environmental engagement are charged a lower cost of debt, and there is evidence on a weak link to higher credit ratings. Particularly the supply of innovative products and services with environmental benefits, and the firm's efforts to reduce its impact on climate change and air pollution through the use of clean energy, energy efficiency, or its commitment to climate-friendly policies and practices, are associated with lower bond spreads. We find no evidence in support of the view that the stated relations are consistently stronger for firms in high-risk industries. However, our results indicate that environmental management practices have become increasingly relevant to bond investors over the recent decade. These outcomes are robust to controls for numerous credit risk determinants, varying model specifications, and industry membership.

The findings of this chapter extend earlier research by showing that the credit market does not only respond to the potential misreporting of existing environmental liabilities, but also prices the environmental management of borrowing firms in anticipation of associated losses. We present the first evidence that a proactive environmental engagement of firms is associated with a lower credit risk. However, since this relation is primarily reflected in bond prices, it may indicate that credit rating agencies do not yet fully account for this effect. The results are consistent with the view that the regulatory implications of climate change have sensitized lenders to the downside risk of poor environmental practices. Furthermore, we show that an assessment of past and ongoing corporate environmental activities enhances the accuracy in the pricing of corporate bond issues, by enabling bond investors to evaluate the risk of environmental performance related losses. Our findings contribute to a better understanding of how corporate environmental activities affect the credit standing of firms, and provide risk managers with improved guidance on where to focus their attention. 


\section{A Appendix}

\section{TABLE 3.A1}

\section{Recoding credit rating classifications}

We standardize the bond and issuer rating classifications according to the rating schedule presented in Panel A. We base Bond Rating on equally weighted Moody's and S\&P bond issue ratings collected from Mergent FISD (Columns 1 and 2), and Issuer Rating on S\&P's long-term domestic issuer ratings as compiled by Compustat (Column 3). Column 4 lists the S\&P and Moody's ratings, which we collapse into seven categories ranging from one (lowest creditworthiness) to seven (highest credit-worthiness). This approach follows Ashbaugh-Skaife et al. (2006). Debt to which we assign a rating category of one to three (i.e. below BBB-) constitutes speculative grade debt, and that between four and seven represents investment grade debt. Panel B presents summary statistics of the recoded Bond Rating and Issuer Rating distributions.

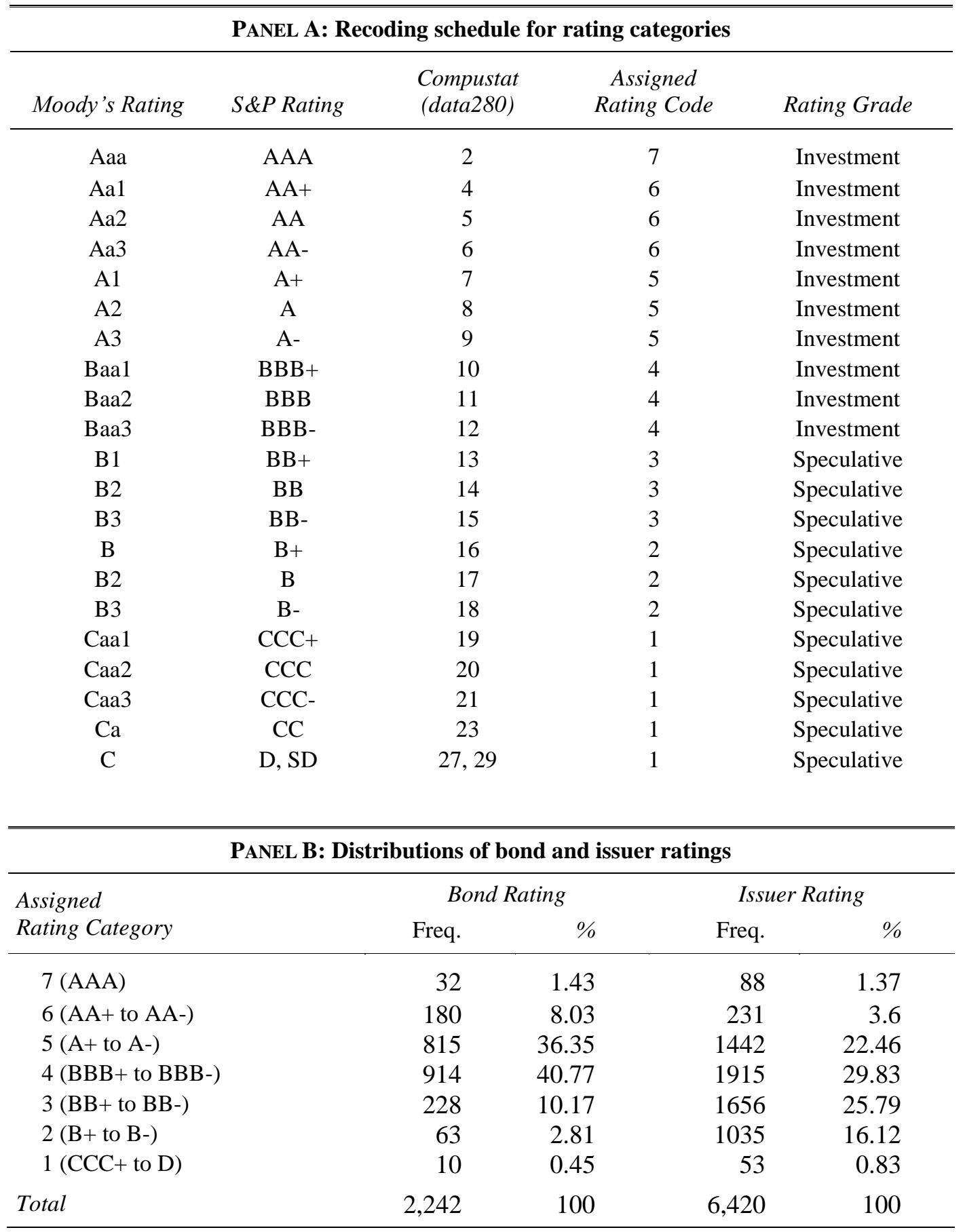


TABLE 3.A2

\section{Variable definitions and predicted relations}

This table describes the variables that we use in our analysis. Column 1 reports the variable categories, names, and data sources. Column 2 lists their predicted relations with the dependent variables, the Cost of Debt financing and credit ratings (Bond Rating, Issuer Rating), respectively. Column 3 provides variable definitions, and Column 4 denotes the data items or categories used within each data source.

\begin{tabular}{|c|c|c|c|}
\hline Variables & $\begin{array}{l}\text { Predicted Sign } \\
\text { Spread/Ratings }\end{array}$ & Definition & Data Items \\
\hline \multicolumn{4}{|c|}{ Environmental performance rating (KLD Stats) } \\
\hline $\mathrm{ENV}_{\text {Strengths }}$ & $-1+$ & Sum of environmental performance strengths & 'Environment' dimension \\
\hline $\mathrm{ENV}_{\text {Concerns }}$ & $+1-$ & Sum of environmental performance concerns & 'Environment' dimension \\
\hline $\mathrm{ENV}_{\text {Total }}$ & $+1-$ & $\begin{array}{l}\text { Aggregate environmental performance, i.e., } \\
\text { difference between } \mathrm{ENV}_{\text {Strengths }} \text { and } E N V_{\text {Concerns. }}\end{array}$ & 'Environment' dimension \\
\hline \multicolumn{4}{|c|}{ Credit issuer specific controls (Compustat North America) } \\
\hline Leverage & $+/-$ & Total liabilities / Total assets & $($ data181/data6)*100 \\
\hline Size & $-1+$ & Natural logarithm of total assets. & $\ln ($ data6) \\
\hline Capital Intensity & $-1+$ & Gross property, plant \& equipment / Total assets & $($ data $7 /$ data 6$) * 100$ \\
\hline Interest Coverage & $-1+$ & $\begin{array}{l}\text { Operating income before depreciation / } \\
\text { Interest expense }\end{array}$ & data13/(data15 or data339) \\
\hline Return on Assets & $-1+$ & Income before extraordinary items / Total assets & $($ data $18 /$ data6) $* 100$ \\
\hline Loss & $+1-$ & $\begin{array}{l}\text { Equal to one if the net income before extraordinary } \\
\text { items is negative in current and prior fiscal year, } \\
\text { otherwise zero. }\end{array}$ & data18 \\
\hline \multicolumn{4}{|c|}{ Credit issue specific controls (Mergent FISD) } \\
\hline TTM & $+1-$ & $\begin{array}{l}\text { Time-to-maturity, the time until expiration of the } \\
\text { bond contract. }\end{array}$ & offering_date ; maturity \\
\hline Issue Size & $?$ & $\begin{array}{l}\text { Natural logarithm of the par value of debt originally } \\
\text { issued. }\end{array}$ & offering_amt \\
\hline Subordinated & $+1-$ & $\begin{array}{l}\text { Equal to one if bond issue classifies as senior- } \\
\text { subordinated, otherwise zero. }\end{array}$ & security_level \\
\hline Speculative & $+/-$ & $\begin{array}{l}\text { Equal to one if firm has subordinated debt, otherwise } \\
\text { zero. }\end{array}$ & Rating \\
\hline Brmod & $-1+$ & $\begin{array}{l}\text { Bond rating that is orthogonalized with respect to } \\
E N V_{\text {Strengths }} \text { and } E N V_{\text {Concerns. }}\end{array}$ & $\% \mathrm{Cov}$ \\
\hline
\end{tabular}


TABLE 3.A3

Credit risk implications of environmental performance activities (non-orthogonalized)

This table summarizes the effect of individual environmental performance factors on credit risk. We decompose our measures of environmental management performance $\left(E N V_{\text {Strengths, }}, \mathrm{ENV}_{\text {Concerns }}\right)$ and test the effect of their components on the cost of debt financing and credit ratings. Note that the environmental performance indicators in this test are not orthonalized with respect to each other. The control variables are not reported for brevity. All models control for year and industry fixed effects (2-digit SIC codes), and estimate standard errors that are clustered at the industry level (2-digit SIC code). Robust $t$-statistics are reported in parentheses below the coefficients.

\begin{tabular}{|c|c|c|c|}
\hline & $\ln ($ Spread $)$ & Bond Rating & Issuer Rating \\
\hline \multicolumn{4}{|l|}{$\mathrm{ENV}_{\text {Strengths }}$} \\
\hline Beneficial Products & $\begin{array}{l}-0.1784 * * * \\
(-3.33)\end{array}$ & $\begin{array}{l}-28.52 * * \\
(-2.08)\end{array}$ & $\begin{array}{l}-0.0126 \\
(-0.05)\end{array}$ \\
\hline Pollution Prevention & $\begin{array}{l}0.0228 \\
(0.35)\end{array}$ & $\begin{array}{l}10.66 \\
(0.76)\end{array}$ & $\begin{array}{l}0.2289 \\
(0.63)\end{array}$ \\
\hline Recycling & $\begin{array}{l}-0.1039 \\
(-1.21)\end{array}$ & $\begin{array}{l}-20.51 \\
(-1.11)\end{array}$ & $\begin{array}{l}-0.0458 \\
(-0.15)\end{array}$ \\
\hline Clean Energy & $\begin{array}{l}-0.0678^{* *} \\
(-2.62)\end{array}$ & $\begin{array}{l}-18.01 * * * \\
(-3.92)\end{array}$ & $\begin{array}{l}0.2579 * \\
(1.79)\end{array}$ \\
\hline Other Strength & $\begin{array}{l}-0.1578^{*} \\
(-1.65)\end{array}$ & $\begin{array}{l}-11.78 \\
(-1.15)\end{array}$ & $\begin{array}{l}0.2718^{*} \\
(1.72)\end{array}$ \\
\hline \multicolumn{4}{|l|}{$\mathrm{ENV}_{\text {Concerns }}$} \\
\hline Hazardous Waste & $\begin{array}{l}0.0001 \\
(0.00)\end{array}$ & $\begin{array}{l}2.89 \\
(0.22)\end{array}$ & $\begin{array}{l}-0.3295 \\
(-1.06)\end{array}$ \\
\hline Regulatory Problems & $\begin{array}{l}0.1432 * * \\
(2.28)\end{array}$ & $\begin{array}{l}35.59 * * * \\
(2.83)\end{array}$ & $\begin{array}{l}-0.3276 \\
(-1.05)\end{array}$ \\
\hline Substantial Emissions & $\begin{array}{l}0.0843 \\
(1.36)\end{array}$ & $\begin{array}{l}14.16 \\
(1.01)\end{array}$ & $\begin{array}{l}-0.4626 \\
(-1.03)\end{array}$ \\
\hline Agricultural Chemicals & $\begin{array}{l}-0.0482 \\
(-1.00)\end{array}$ & $\begin{array}{l}-42.81 * * * \\
(-4.06)\end{array}$ & $\begin{array}{l}-0.1302 \\
(-0.37)\end{array}$ \\
\hline Climate Change & $\begin{array}{l}0.2348 * * * \\
(5.35)\end{array}$ & $\begin{array}{l}54.53 * * * \\
(6.83)\end{array}$ & $\begin{array}{l}-0.4586 \\
(-1.14)\end{array}$ \\
\hline Other Concern & $\begin{array}{l}0.0045 \\
(0.10)\end{array}$ & $\begin{array}{l}-6.17 \\
(-0.61)\end{array}$ & $\begin{array}{l}-0.1024 \\
(-0.42)\end{array}$ \\
\hline Year Fixed Effects & Yes & Yes & Yes \\
\hline Industry Fixed Effects & Yes & Yes & Yes \\
\hline Adj. R² / Pseudo R ${ }^{2}$ & 0.72 & 0.61 & 0.34 \\
\hline \# Observations & 1,545 & 1,567 & 1,674 \\
\hline
\end{tabular}

$* * * \mathrm{p}<0.01, * * \mathrm{p}<0.05, * \mathrm{p}<0.1$ 


\title{
Chapter 4
}

\section{Does the Market Misprice Customer Satisfaction? New evidence on errors in investors' expectations*}

\begin{abstract}
This chapter follows up on the current marketing-finance debate on whether customer satisfaction is associated with abnormal stock returns. Previous studies suggest that such a relation exists because investors neglect customer satisfaction in their valuation of firms. I examine the key mechanisms through which customer satisfaction manifests in abnormal stock returns when the suggested errors-in-expectations hypothesis holds. My findings show that: (i) customer satisfaction indeed has positive implications for the future earnings of firms; (ii) investors seem to correctly anticipate the future earnings associated with customer satisfaction over various forecast horizons; (iii) stock price reactions around the earnings announcements of firms are unrelated to customer satisfaction, which implies that investors are not surprised by, and thus don't correct for, systematic errors in their expectations of future earnings.
\end{abstract}

\subsection{Introduction}

Researchers in marketing increasingly examine how financial markets respond to the dynamics of market-based assets and strategies that are deemed to be consequential to firms' cash flows. An important research agenda within this domain is the stock market's response to news about customer satisfaction. There is an ongoing debate about whether investors quickly and adequately anticipate the implications of customer satisfaction for firm performance. This debate has motivated researchers to investigate whether customer satisfaction leads to either stock price changes in the short run (Ittner and Larcker, 1998; Fornell, Mithas, Morgeson III, and Krishnan, 2006; Ittner, Larcker, and Taylor, 2009) or abnormal stock returns in the long run (Fornell et al., 2006; Aksoy, Cooil, Groening, Keiningham, and Yalçin, 2008; O'Sullivan, Hutchinson, and O'Connell, 2009; Jacobson and Mizik, 2009a; Ittner et al., 2009). These studies have yet to reach agreement about the stock market's pricing of customer satisfaction.

However, the finance literature has taught us that long-term abnormal stock returns are imperfect measures of stock market mispricing. This caveat traces back to the "joint-hypothesis problem": Tests of "abnormal" returns inherently rely on an equilibrium model and an underlying asset pricing theory that defines "normal" security returns, and consequently we

\footnotetext{
* This chapter is based on Derwall, Hann, and Kalogeras (2011), which was presented at the 2010 Marketing Science Conference (Cologne, Germany).
} 
cannot determine whether abnormal returns are due to incorrect asset pricing models or due to market inefficiency. For example, instead of reflecting errors in investors' expectations about firms' future earnings, abnormal returns may simply represent risk premiums that are not captured by the models that researchers have used so far to measure equilibrium expected returns. $^{26}$

The mixed conclusions from earlier studies together with the difficulties with long-term abnormal returns create a strong appetite for alternative methods that shed light on the stock market's pricing of customer satisfaction (see, e.g., comments by Fornell, Mithas, and Morgeson III, 2009a, b; Jacobson and Mizik, 2009b). In this study, we propose alternative and highly complementary ways for testing whether customer satisfaction causes long-term abnormal stock returns because of systematic errors in investors' expectations of firms' future earnings. The methods that we introduce are used extensively in the finance and accounting literatures that focus on potential sources of stock market inefficiency. ${ }^{27}$ These more directly acknowledge that when errors in expectations cause a relation between customer satisfaction and abnormal long-term stock performance, we should find that investors systematically misjudge the relation between customer satisfaction and future earnings. For example, investors' too pessimistic expectations about firms with strong customer satisfaction, which is suggested in earlier studies, should lead to stock prices that are lower than stock prices that reflect the firms' fundamental value. Consequently, subsequent earnings announcements should reveal that the expectations implied by these prices are too pessimistic, which should result in positive abnormal stock returns. Therefore, important in testing whether abnormal stock returns, if any, are caused by errors in expectations is to (i) test explicitly for systematic errors in investors' expectations, and (ii) to test whether subsequent events informing investors of their errors are a primary source of the long-term abnormal return. If the errors-in-expectations hypothesis holds, then we expect that abnormal returns cluster around these events and explain much of the long-term abnormal return on satisfaction-based trading strategies.

Using errors in analysts' forecast of firms' future earnings as well as stock price reactions around firms' earnings announcements, this study introduces sharper tests of expectational errors by investors that can cause firms to display abnormal stock returns. Specifically, as a first step, we verify that customer satisfaction is associated with firms' future earnings. We then present two ways to examine whether investors anticipate the earnings implications of customer satisfaction: (i) an analysis of the relation between customer satisfaction and errors in investors' earnings forecasts, as measured by analysts' forecasts of firms' future earnings, and (ii) an analysis of the relation between customer satisfaction and stock price changes following firms' earnings announcements. If, for example, superior customer satisfaction causes positive abnormal returns because of errors in expectations, then analysts forecasts of future earnings should be systematically too low (relative to actual earnings) for firms with strong customer satisfaction, and stock price changes following earnings announcements should be positive.

For various forecast horizons, we find in most cases that analysts anticipate the positive association between customer satisfaction and future earnings, which suggests that the earnings

\footnotetext{
${ }^{26}$ According to Fama-and French (1993), for example, the return difference between stocks with high book-toprice ratios and those with low book-to-price ratios represent a premium for risks that the CAPM fails to capture, and these authors consequently advocate adding this return difference as a separate factor in pricing models.

${ }^{27}$ See, e.g., Abarbanell and Bernard (1992), Chen, Jegadeesh, and Lakonishok (1996), La Porta, Lakonishok, Shleifer, and Vishny (1997), Bradshaw, Richardson, and Sloan (2001), Skinner and Sloan (2002), Core, Guay, and Rusticus (2006), and Edmans (2011).
} 
that firms realize through customer satisfaction does not surprise investors. This conclusion finds even stronger support in stock price reactions to firms' earnings announcements and customer satisfaction. Neither firms with strong customer satisfaction nor firms with weak customer satisfaction experience statistically significant abnormal stock returns around earnings announcements. Taken together, our results reject the hypothesis that customer satisfaction causes abnormal stock returns because of errors in investors' expectations.

This study makes at least two important contributions to the literature. First, this study explicitly tests whether investors are systematically surprised by the relation between customer satisfaction and future earnings, and if so, whether these surprises are the source of abnormal stock returns. By doing so, the study sheds new light on the ongoing debate about the stock market's pricing of customer satisfaction and its implications for firms' stock returns.

Second, our analytical framework lays new foundations for the marketing-finance interface literature, which calls for methods and metrics that explain how marketing translates into financial outcomes. Recent examples are Hanssens, Rust, and Srivastava (2009), Srinivasan and Hanssens (2009), and Kimbrough and McAlister (2009). While our analyses focus on customer satisfaction, taken together, they comprise an all-encompassing framework for understanding the channels of transmission from any marketing-related activity to operating performance, firm value, investors' earnings expectations, and ultimately, stock market performance. It is common practice in the finance and accounting literatures to rely on these tests to make distinctions between stock returns that are anomalous due to market mispricing and stock returns that are due to differences in riskiness that is "priced" in an efficient market. Many of these studies show that patterns in analyst forecast errors and earnings announcement returns explain anomalous patterns in stock returns.

The paper proceeds as follows. Section 2 outlines the theoretical framework that we put forward for understanding the channels of transmission from customer satisfaction to abnormal stock returns caused by errors in investors' expectations of firms' future performance. Section 3 presents the hypotheses that are central to this study. Section 4 discusses the data. Section 5 presents the different hypothesis tests and their results. Section 6 concludes this study.

\subsection{Background and Theoretical Framework}

The finance and accounting literatures have a long tradition of developing tests for the efficient markets hypothesis and for understanding what causes stock market anomalies. Taken together, all of these studies form a theoretical framework that we rely on in our investigation into the stock markets' ability to price customer satisfaction efficiently, and its implications for the behavior of stock prices. Inspired by Ittner et al. (2009), we outline a number of conditions that lay the foundations for the errors-in-expectations hypothesis, and these conditions motivate a sequence of complementary empirical tests.

The first condition is that customer satisfaction influences the future earnings of firms, ceteris paribus. When the first condition holds, there is a priori a reason for investors to incorporate information about customer satisfaction into the valuation of companies. Whether information about customer satisfaction satisfies the first condition has received considerable attention in the marketing literature. Empirical evidence supports the idea that by having strong customer satisfaction a firm positively influences various drivers of future earnings, such as productivity (Anderson, Fornell, and Rust, 1997), profit margins (Ittner et al., 2009), return on 
assets (ROA), and return on invested capital (ROI) (e.g., Anderson, Fornell, and Lehmann, 1994; Anderson et al., 1997; Ittner et al., 2009).

The second condition of the errors-in-expectations hypothesis is that investors systematically underestimate or overestimate the influence of customer satisfaction on firms' future earnings. Whether the second condition of the errors-in-expectations hypothesis finds support in empirical evidence is still the subject of debate. On the one hand, Anderson et al. (2004) find that firms with stronger customer satisfaction have higher equity prices, higher price/book ratios, and a higher Tobin's $q$, which could imply that stock prices are reflective of value-relevant information about customer satisfaction. On the other hand, these variables teach us little about the speed and extent of incorporation, i.e., the extent to which news about customer satisfaction is quickly and fully factored into stock prices. Studies that investigate whether stock prices immediately react to new information about customer satisfaction have yet to reach consensus. Ittner and Larcker (1998) and Fornell et al. (2006) find that firms for which new information about customer satisfaction enters the market do not experience immediate stock price reactions, which suggests that the financial market misprices customer satisfaction (assuming that condition 1 holds). But Ittner et al. (2009) do find that the stock market responds to information about improved customer satisfaction when improvements are relatively large.

The third condition is that information about customer satisfaction predicts long-run abnormal stock returns. For example, if investors do not fully anticipate the influence of customer satisfaction on future earnings, then long-term abnormal returns can be achieved by means of trading strategies that exploit information about customer satisfaction. The portfolio returns are abnormal in the sense that they exceed over the long run the return that investors are expected to earn in an efficient market as a compensation for bearing the portfolio's risk. The aforementioned evidence that customer satisfaction relates positively to firm performance but that stock prices do not immediately respond to satisfaction news has prompted researchers to devote substantial attention to these trading strategies. Fornell et al. (2006) found that a portfolio composed of the $20 \%$ of firms that rank highest on the American Customer Satisfaction Index (ACSI) relative to competition and the national average score outperform all remaining firms as well as broad market indexes. Aksoy et al. (2008) suggest that a portfolio composed of firms with higher-than-average scores on the ACSI and which also experience positive changes in the ACSI earns a return that exceeds the return predicted by multifactor risk models. They interpret the abnormal return as evidence that the market is slow to recognize the positive effects of customer satisfaction on firms' future earnings, consistent with the errors-inexpectations hypothesis. However, Jacobson and Mizik (2009a) report that much of the abnormal returns on the portfolios mentioned in Aksoy et al. (2008) are due to a few stocks from the internet and utilities industries, which suggests that the mispricing of customer satisfaction is not widespread. O'Sullivan et al. (2009) find no evidence that trading strategies based on ASCI deliver abnormal long-term returns, and also Ittner et al. (2009) suggest that abnormal long-term returns associated with portfolios that are formed based on the ACSI are not evident.

Because of the inconsistency in methodologies and results across these studies, Ittner et al. (2009) propose three consecutive tests to investigate whether all three conditions holds in one single sample. Their proposed analytical framework concerns (i) the relation between customer satisfaction and return on assets, (ii) stock market responses immediately following satisfaction news, and (iii) the long-run abnormal returns on portfolios formed using firms' scores on customer satisfaction. However, short-run event studies do not resolve the question whether the 
financial market under- or overreacts to information about customer satisfaction, and long-term performance studies have been shown to be sensitive to (mis)specification of the expected return model.

For example, finding that stock markets do not immediately react to new information about customer satisfaction could imply that investors are slow to recognize the value implications of customer satisfaction, but could also indicate that evidence to support condition 1 is merely spurious. Moreover, a firm's stock price may increase subsequent to positive news about customer satisfaction even when investors fail to anticipate higher future earnings because they might expect a lower risk (which implies a decrease in the rate at which earnings are discounted). The latter idea has recently found support in evidence by Tuli and Bharadwaj (2009), who document that firms that experience an increase in customer satisfaction also experience decreases in the stock's systematic and idiosyncratic risks.

As for studies that focus on long-term abnormal returns, their results are plagued by debates on the appropriate expected-return model. Abnormal returns derived in prior studies of long-term portfolio performance are unavoidably vulnerable to the critique of incorrect benchmarking, which has been articulated by a substantial number of studies in the finance literature (see, e.g., Roll, 1977; Lehman and Modest, 1987; Fama and French, 1993). The problem is exacerbated by the fact that stocks of firms with strong customer satisfaction tend to be large-cap stocks with high price-to-book ratios, which according to Cremers, Petajisto, and Zitzewitz (2009) tend to produce abnormal returns under the Fama and French (1993) model because its benchmark factors put disproportionate weights on small-cap stocks with low pricebook ratios. Because of these and other methodological shortcomings, researchers (e.g., Jacobsen and Mizik, 2009b) emphasize the need for studies that provide alternative measures of the market's expectations of firms' future earnings instead of relying on long-term abnormal stock returns only.

In essence, there is a need for explicit tests of whether errors in investors' expectations about the future earnings of firms can be traced to customer satisfaction. And subsequently, if investors misunderstand the relation between customer satisfaction and future earnings, events that reveal actual future earnings information should be associated with abnormal stock returns. For example, if the abnormal stock returns in Aksoy et al. (2008) for firms with strong customer satisfaction represent a delayed response to predictable changes in these firms' future earnings, then we would expect the returns to be clustered around future earnings announcements. Whether expectational errors by investors, if any, are manifested this way in abnormal earnings announcement returns has yet to be investigated. This paper fills these critical gaps in the literature, by studying consecutively the relation between customer satisfaction and accounting return on assets (testing condition 1), errors in investor forecasts of firms' future earnings as measured by errors in consensus forecast of analysts (testing condition 2), and stock price reactions around firms' earnings announcement (testing condition 2 and 3).

\subsection{Hypothesis Development}

\subsubsection{Customer satisfaction and future operating performance}

The abovementioned discussion highlights that prior to establishing that investors misunderstand the relation between customer satisfaction and firms' future earnings, we need to establish that such a relation exists in the first place. From a theoretical perspective, 
researchers have suggested that firms with better customer satisfaction realize higher future cash flows through various economic channels, such as a higher productivity, higher revenues and profit margins, and a higher operating and net income. We reexamine this relation for our sample, and formalize it in null form as follows:

Hypothesis 1: Customer satisfaction is not associated with a firm's future earnings.

\subsubsection{Customer satisfaction and errors in investors' expectations}

Finding that customer satisfaction relates to firms' future earnings justifies neither the conclusion that the stock market misprices news about customer satisfaction nor the implication that investors can earn abnormal returns by utilizing the mispriced information in trading strategies. The key ingredient of the mispricing story, which prior literatures have not explored explicitly, is that the future earnings that firms can generate as a result of customer satisfaction are to some extent unexpected by investors. For example, the earlier evidence in Fornell et al. (2006) and Aksoy et al. (2008) that firms with strong customer satisfaction achieve superior (risk-adjusted) stock market returns can be taken to imply expectational errors among investors, but only when investors systematically underestimated the positive relation between customer satisfaction and firms' future earnings. If the latter does not hold, then the observed abnormal returns may point to explanations other than errors in expectations, such as a misspecification or poor estimation of the employed (benchmark) model that measures equilibrium expected stock returns, or a sample-specific statistical artifact.

We develop two hypotheses that explicitly address whether investors are surprised by the relation between customer satisfaction and future performance. For testing one of these hypotheses, we use analysts' forecasts of firms' future earnings (growth) as a proxy for investors' expectations of future earnings. If better customer satisfaction causes superior riskadjusted stock returns because of errors in investors' expectations, we would expect that firms with strong customer satisfaction systematically generate more positive unexpected earnings (i.e., relative to forecasted earnings) than do firms with weaker customer satisfaction. Stated in null form, the following hypothesis about errors in analysts' earnings forecasts is tested:

\section{Hypothesis 2: Customer satisfaction is not associated with analysts' earnings forecast errors.}

Implicit in Hypothesis 2 is the assumption that analysts' forecasts are reflective of investors' expectations. Thus, the assumption here is that investors' expectations about future earnings that are impounded in stock prices are at least as sophisticated as the expectations of analysts. Indeed, sell-side analysts' forecasts of earnings have often been shown to be more accurate and a better reflection of market expectations than alternative forecasts, such as simple earnings time-series models. ${ }^{28} \mathrm{~A}$ large body of research has used analyst forecast errors as a proxy for investors' earnings expectations to distinguish between stock returns that are abnormal due to investors' biased earnings expectations and stock returns that are attributable

\footnotetext{
${ }^{28}$ For an extensive discussion, see e.g., Kothari (2001).
} 
to a risk premium in an efficient market. For this reason, the forecast error test is suitable for understanding abnormal returns associated with customer satisfaction portfolios.

We nevertheless also consider a more direct way of assessing errors in the market's expectations using returns around firms' earnings announcements. ${ }^{29}$ If customer satisfaction causes abnormal returns because of errors in expectations, we should see stock price changes that reflect investors' learning about their incorrect expectations as soon as information about firms' actual future earnings is released. For example, if the market is too pessimistic about the implications of customer satisfaction for future firm performance, we would expect that firms with strong customer satisfaction experience stock returns immediately following earnings announcements that are higher than those of firms with weaker customer satisfaction. If customer satisfaction is the sole source of stock mispricing, and if all of the learning about incorrect expectations takes place at the time of earnings announcements, then we expect that earnings announcement returns capture the long-term abnormal returns associated with investment strategies that try to exploit mispricing of information about customer satisfaction. The null hypothesis concerning stock price reactions around earning announcements is stated as follows:

\section{Hypothesis 3: Customer satisfaction is not associated with earnings announcement returns.}

We hasten to emphasize the difference between our investigation into stock price changes following earnings announcement dates and previous studies on stock price changes following news on customer satisfaction on the date that they become publicly available. If the stock market responds immediately and adequately to new information about customer satisfaction, then we would expect that stock price changes take place immediately following the release of this information. In that case, earnings announcements should not reveal unanticipated earnings and hence stock price changes around earnings announcement dates should be unrelated to customer satisfaction. Earlier studies that found no clear-cut response following news about customer satisfaction motivate our examination of the market's reaction following the realization of unexpected earnings, at the time of earnings announcements.

\subsection{Data}

Our study relies on the American Customer Satisfaction Index (ACSI) introduced by Fornell, Johnson, and Anderson (1996), which has been the focus of the vast majority of studies on the financial market's response to information about customer satisfaction. The index periodically measures customer satisfaction for a range of more than 200 firms that hold a significant market share in their respective industry, and jointly cover a substantial portion of the U.S. economy. ${ }^{30}$ The ACSI metric is released on an annual basis, but it is important to note that the

\footnotetext{
${ }^{29}$ While earnings announcement returns provide sharper tests of investors' biased expectations than do analyst forecast errors, one potential limitation of studying earnings announcement returns is that firms may reveal actual earnings information prior to official earnings announcement dates. For this reason, the two tests are regarded as complementary in studies of errors in investors' expectations.

${ }^{30}$ The data are publicly available at http://www.theacsi.org.
} 
release date differs across firms, depending on their membership in one of the 10 economic sectors that are covered. ${ }^{31}$ Because the ACSI database has undergone an increase in coverage over time, and individual companies are added or deleted from ACSI as their market position changes or as a result of mergers and acquisitions, we study a changing cross-section of firms. We collect ACSI data from May 1995 to December 2008 for firms that are listed on the U.S. stock markets, and from these exclude multi-brand and non-domestic firms.

\section{TABLE 4.1}

\section{Descriptive statistics - Panel A}

This table reports summary statistics and additional details on the variables that are applied in our analysis of the relation between customer satisfaction and operating performance as well as earnings forecast errors.

\begin{tabular}{|c|c|c|c|c|c|}
\hline Variable & \# Obs. & Mean & Std. Dev. & Min. & Max. \\
\hline \multicolumn{6}{|l|}{ Operating Performance Analysis } \\
\hline $\operatorname{ACSI}_{t-1}$ & 1,096 & 76 & 6.03 & 49 & 88 \\
\hline Return on assets (ROA) & 1,096 & 0.14 & 0.08 & -0.32 & 0.59 \\
\hline Total assets (in millions of $\$$ ) & 1,096 & 35,816 & 115,088 & 172 & $2,187,631$ \\
\hline Book-to-market equity $\mathrm{t}_{\mathrm{t}-1}$ & 1,096 & 0.56 & 0.99 & -26.87 & 6.62 \\
\hline Market value of equity $\mathrm{t}_{\mathrm{t}-1}$ (in millions of $\$$ ) & 1,096 & 27,258 & 50,632 & 10 & 508,330 \\
\hline \multicolumn{6}{|l|}{ Forecast Errors Analysis } \\
\hline ACSI & 808 & 76 & 5.77 & 49 & 88 \\
\hline Forecast error (1-year)/total assets per share & 808 & -0.0013 & 0.0161 & -0.2968 & 0.1418 \\
\hline Forecast error (1-year)/price & 736 & -0.0021 & 0.0256 & -0.4110 & 0.1000 \\
\hline Number of forecasts in consensus & 808 & 17.28 & 6.72 & 1 & 42 \\
\hline Dispersion of analyst forecasts & 806 & 0.04 & 0.13 & -1.21 & 1.83 \\
\hline Forecast error (2-year)/total assets per share & 692 & -0.0039 & 0.0254 & -0.1133 & 0.4407 \\
\hline Forecast error (2-year)/price & 626 & -0.0061 & 0.0419 & -0.6759 & 0.1938 \\
\hline Number of forecasts in consensus & 692 & 13.22 & 5.56 & 1 & 32 \\
\hline Dispersion of analyst forecasts & 688 & 0.05 & 0.44 & -8.87 & 6.94 \\
\hline Median long-term growth forecast & 421 & 0.1086 & 0.0543 & 0.0100 & 0.5000 \\
\hline Actual annualized five-year EPS growth rate & 421 & 0.0658 & 0.1798 & -0.4199 & 1.5097 \\
\hline Forecast error in long-term growth forecast & 421 & -0.04 & 0.17 & -0.5414 & 1.4097 \\
\hline Number of forecasts in consensus & 421 & 0.12 & 0.04 & 0.02 & 0.23 \\
\hline Dispersion of analyst forecasts & 421 & 0.00 & 0.01 & -0.05 & 0.13 \\
\hline Book-to-market equity $\mathrm{t}_{\mathrm{t}-1}$ & 808 & 0.55 & 0.43 & 0.01 & 2.75 \\
\hline Market value of equity $\mathrm{t}_{\mathrm{t}-1}$ (in millions of \$) & 808 & 28,428 & 52,788 & 58 & 508,330 \\
\hline
\end{tabular}

\footnotetext{
${ }^{31}$ Customer satisfaction information for one or more these economic sectors is generally updated in the following months: February (retail, finance \& insurance, e-commerce), May (transportation \& warehousing, information, utilities, health care \& social assistance, accommodation \& food services), August (manufacturing durables, ebusiness), and November (manufacturing non-durables).
} 


\section{TABLE 4.1 (continued)}

\section{Descriptive statistics - Panel B}

This table reports summary statistics for the variables that we use in our analysis of the relation between customer satisfaction and earnings announcement returns.

\begin{tabular}{lrrrrr}
\hline \hline Variable & \# Obs. & Mean & Std. Dev. & Min. & Max. \\
\hline Earnings Announcements Return Analysis & & & & & \\
ACSI $_{\mathrm{t}-1}$ & 3,266 & 76 & 5.92 & 49 & 88 \\
$\quad$ Quintile 5 (Top) & 757 & 83 & 1.85 & 81 & 88 \\
$\quad$ Quintile 4 & 681 & 79 & 1.30 & 77 & 82 \\
$\quad$ Quintile 3 & 575 & 76 & 1.00 & 74 & 79 \\
$\quad$ Quintile 2 & 694 & 73 & 1.32 & 70 & 76 \\
Quintile 1 (Bottom) & 559 & 67 & 3.54 & 49 & 72 \\
Excess Return (R-rf) & & & & & \\
$\quad(-1,1)$ day event window & & & & & \\
$\quad(-3,3)$ day event window & 3,266 & $0.09 \%$ & $1.96 \%$ & $-12.68 \%$ & $10.88 \%$ \\
$\quad(-5,5)$ day event window & 3,266 & $0.07 \%$ & $1.01 \%$ & $-5.87 \%$ & $6.42 \%$ \\
$\quad(-10,10)$ day event window & 3,266 & $0.08 \%$ & $0.73 \%$ & $-3.46 \%$ & $5.79 \%$ \\
Cumulative Abnormal Return (CAR) & 3,266 & $0.07 \%$ & $0.48 \%$ & $-2.31 \%$ & $4.37 \%$ \\
$\quad(-1,1)$ day event window & & & & & \\
$\quad(-3,3)$ day event window & 3,266 & $0.13 \%$ & $5.63 \%$ & $-37.35 \%$ & $34.89 \%$ \\
$\quad(-5,5)$ day event window & 3,266 & $0.20 \%$ & $6.67 \%$ & $-37.31 \%$ & $44.21 \%$ \\
$\quad(-10,10)$ day event window & 3,266 & $0.28 \%$ & $7.51 \%$ & $-42.88 \%$ & $51.37 \%$ \\
\end{tabular}

For our investigation into the link between customer satisfaction and firms' earnings, analysts' forecasts of firms' future earnings, and stock market reactions around earnings announcements, we require a match between firms in the ACSI universe and that of various financial databases. We collect daily stock returns on ordinary common shares from the Center for Research in Securities Prices (CRSP) database, annual company fundamentals and quarterly earnings announcement dates from the Compustat library, and analysts' forecasts of future earnings together with firms' actual earnings values from the Institutional Brokers' Estimates System (I/B/E/S). We further exclude subsidiaries and privately held firms, non-traded companies or securities, consolidated parent or tracking stock companies, leveraged buyouts, and over-the-counter securities from the matched samples. Our final sample contains information on 159 firms with 1,096 firm year observations. Table 4.1 reports summary statistics, while Table 4.A1 in the Appendix provides a detailed overview on the variables and databases. 


\subsection{Empirical Analysis}

\subsubsection{Customer satisfaction and future operating performance}

We first investigate the relation between customer satisfaction and future earnings to test Hypothesis 1. Using returns on assets (ROA) as a measure of earnings, we estimate models of the form:

$$
R O A_{i, t}=\alpha+\beta A C S I_{i, t-n}+\sum_{k=1}^{K} \gamma_{k} C_{k, i, t-1}+\varepsilon_{i, t}
$$

where $R O A_{i, t}$ is firm $i$ 's operating income before depreciation scaled by the total book value of its assets. ${ }^{32} A C S I_{i, t-n}$ is the n-year lagged ACSI score assigned to firm $i$, and $C_{k, t-1}$ is the one-year lagged value for control variable $k$, where $K$ denotes the number of control variables. We choose ROA not only because this measure helps us to verify prior related studies with the help of an extended sample period, but also because ROA has more desirable distributional characteristics than other proxies of operating cash flows (Barber and Lyon 1996). Next to modeling ROA using the ACSI lagged by one year we also lag this variable by two years and five years. The objective of using these alternative lags is to see whether the ACSI contains relevant information for the cash flow predictions of investors at those forecast horizons that are central to most analyst forecasts in practice.

Our set of lagged control variables comprises a measure for firm size, defined as the logarithm of the market value of equity $\left(\log M V E_{t-1}\right)$, and the logarithm of the book-to-market ratio $\left(\log B M E_{t-1}\right)$. These variables have been shown to correlate with profitability (e.g., Fama and French 1995; Core et al. 2006; Ittner et al. 2009) and with customer satisfaction (e.g., Anderson, Fornell, and Mazvancheryl 2004). We also include the lagged ROA as a control variable to account for the high persistence in operating performance that has been documented in previous studies (e.g., Penman, 1992; Fama and French, 2000). One caveat here is that the use of lagged dependent variables in dynamic panels results in inconsistent linear estimators, because these variables are by construction correlated with any unobserved panel-level effects. We consequently estimate a linear dynamic panel model with consistent generalized method of moments (GMM) estimators, based on the work of Arellano and Bover (1995) and Blundell and Bond (1998). The corresponding z-statistics are computed using standard errors that are robust to heteroskedasticity and autocorrelation of the residuals (Windmeijer, 2005). Table 4.2 reports the regression results.

Independent of the model employed, we find that customer satisfaction explains future return on assets. The relationships between ROA and the lagged ACSI variables are positive and statistically significant at the conventional significance levels. These results suggest that in the prediction of future earnings, the ACSI is relevant for making both short-term and longterm forecasts. As for the financial control variables, the book-to-market ratio and the lagged dependent variables have coefficients that are significant and consistent with previous literatures (e.g., Ittner et al., 2009).

\footnotetext{
${ }^{32}$ Previous studies advocate the use of operating income before depreciation since the measure is not affected by managerial discretion in depreciation policy (e.g., Barber and Lyon, 1996). We winsorize ROA at the 0.5\% level to control for a small number of significantly negative outliers.
} 


\section{TABLE 4.2}

\section{Customer satisfaction and operating performance}

This table reports regression results for the effect of customer satisfaction on future operating performance. We use return on assets (ROA) as the measure of operating performance, the ACSI score as measure of customer satisfaction (lagged by one-, two-, or five-years), and include lagged controls for the book-to-market ratio $\left(\log B M E_{t, 1}\right)$, market value of equity $\left(\log M V E_{t-1}\right)$, and operating performance in the preceding year $\left(\mathrm{ROA}_{\mathrm{t}-1}\right)$. To account for the presence of a lagged dependent variable as predictor, we estimate Arellano-Bover/Blundell-Bond linear dynamic panel models that produce generalized method of moments (GMM) consistent estimators. Robust Z-statistics are reported in parentheses below the coefficients.

\begin{tabular}{llll}
\hline \hline ROA & $(\mathrm{n}=1)$ & $(\mathrm{n}=2)$ & $(\mathrm{n}=5)$ \\
\hline ACSI $(\mathrm{t}-\mathrm{n})$ & $0.0011^{* *}$ & $0.0011^{*}$ & $0.0021^{* * *}$ \\
& $(2.02)$ & $(1.94)$ & $(2.87)$ \\
logBME (t-1) & $-0.0207^{* * *}$ & $-0.0206^{* * *}$ & $-0.0168^{* *}$ \\
logMVE (t-1) & $(-4.56)$ & $(-4.23)$ & $(-2.44)$ \\
& 0.0040 & 0.0040 & $0.0088^{*}$ \\
ROA (t-1) & $(1.13)$ & $(1.04)$ & $(1.79)$ \\
Constant & $0.5427^{* * *}$ & $0.5323^{* * *}$ & $0.4272^{* * *}$ \\
& $(8.09)$ & $(8.46)$ & $(5.06)$ \\
Prob. $>$ Chi & -0.0789 & -0.0745 & $-0.1834^{* * *}$ \\
\# Observations & $(-1.43)$ & $(-1.21)$ & $(-2.62)$ \\
\hline
\end{tabular}

$* * * \mathrm{p}<0.01, * * \mathrm{p}<0.05, * \mathrm{p}<0.1$

Windmeijer WC-robust estimator

The results reject Hypothesis 1, and corroborate earlier studies that found that firms with higher ACSI scores tend to be more profitable in the ensuing years. While this result makes a case for investors to value customer satisfaction, it leaves open the question whether ACSI should cause anomalously high stock returns because of investors' incorrect expectations of the positive relation between ACSI and future ROA, as is implicitly suggested by Fornell et al. (2006) and Aksoy et al. (2008). Superior profits associated with better customer satisfaction lead to abnormal stock return only to the extent that they are unexpected by investors, which is the focus of the next sections of this study. 


\subsubsection{Customer satisfaction and earnings forecast errors}

The first step in our analysis of errors in investors' expectations focuses on Hypothesis 2. We use earnings forecasts issued by financial analysts to derive earnings forecast errors, which serve as a proxy for investors' misunderstanding of future earnings. To examine whether investors incorrectly assess the effect of customer satisfaction on operating performance, we regress the earnings forecast errors on ACSI and a set of control variables. The general model takes the form:

$$
F E_{i, t}=\alpha+\beta A C S I_{i, t-n}+\sum_{k=1}^{K} \gamma_{k} C_{k, i, t-n}+\varepsilon_{i, t}
$$

where

$$
F E_{i, t}=\text { Actual Earnings }_{i, t}-{\text { Earnings } \text { Forecast }_{i, t-n}}
$$

$F E_{i t}$ represents the measure of forecast errors, which is defined as the difference between firm $i$ 's actual earnings and the consensus of net income forecasts issued by sell-side analysts in an earlier period. Since the $\mathrm{I} / \mathrm{B} / \mathrm{E} / \mathrm{S}$ database allows us to estimate the model for different forecast horizons, we independently examine errors in one-year (1-yr FE) and two-year (2-yr $F E$ ) forecasts as well as errors in the forecast of long-term earnings growth $(L T G)$, following the approach of La Porta (1996), Core et al. (2006), and Edmans (2011). ${ }^{33}$

Since the majority of annual reports are filed within three months after the fiscal year-end, we measure analysts' forecasts four months after the previous fiscal year-end, to ensure that analysts know prior earnings when making their forecast (Core et al., 2006; Doukas, Kim, and Pantzalis, 2002). The one-year (two-year) forecast error is thus defined as the difference between the I/B/E/S actual annual earnings-per-share and the $\mathrm{I} / \mathrm{B} / \mathrm{E} / \mathrm{S}$ consensus mean forecasts of annual earnings-per-share, latter of which is measured eight months (20 months) before the forecasted earnings period. We scale the forecast errors by the firm's share price at the end of the preceding year in one set of regressions (FE/Price), and by total assets per share in a matching set of regressions (FE/Assets) to control for heteroskedasticity. Scaling the forecast errors by assets is considered complementary because price-scaled forecast errors may become substantially inflated for firms that trade at very low prices. The forecast error in the long-term growth forecast of earnings is defined as the difference in $\mathrm{I} / \mathrm{B} / \mathrm{E} / \mathrm{S}$ actual long-term growth in earnings-per-share and the median I/B/E/S consensus forecasts of long-term growth in earnings measured 56 months earlier (Dechow, Hutton, and Sloan, 2000; Core et al., 2006). Since this measure is already expressed in percentages, we do not deflate it but merely rescale it into decimals to facilitate comparison with the other forecast horizons.

To ensure that customer satisfaction information was available to analysts before they formulated their earnings forecasts, we only consider ACSI information that was published at least a month before the respective forecast dates. The control variables that are included in our regression model again comprise the logarithm of the market value of common stock and the

\footnotetext{
${ }^{33}$ Although analysts use different methodologies to forecast long-term growth in earnings, the LTG forecast in general represents an expected annual increase in operating earnings over the firm's next full business cycle. The LTG usually refers to a time horizon of between three to five years.
} 
logarithm of the book-to-market ratio. Both variables have been shown to explain the variation in forecast errors in earlier studies (e.g. Richardson, Teoh, and Wysocki, 2004; Core et al., 2006; Edmans, 2011).

We run pooled OLS regressions with year fixed effects to estimate the forecast errors, and test for the significance of the coefficients using robust standard errors that are clustered at the firm and year level. Not correcting for the cross-sectional and time-series correlation in the residuals of a firm can result in incorrect t-statistics, because the OLS standard errors might be biased and either over or underestimate the true variability of the coefficient estimates (Petersen, 2009). Table 4.3 reports on regressions for the 1-year and 2-year earnings forecast errors as well as the errors in long-term earnings growth forecasts.

The results consistently indicate that the difference between consensus forecasts of earnings and actual earnings is not significantly associated with customer satisfaction. Neither the price-scaled forecast errors nor the asset-scaled forecast errors over one-year and two-year horizons display a statistically significant relation to the ACSI. Also, the long-term growth forecast error does not relate significantly to the customer satisfaction measure.

\subsubsection{Changes in customer satisfaction and earnings forecast errors}

Ittner et al. (2009) point out that it is questionable that investors systematically fail to incorporate information about future earnings that is conveyed by the levels of the ACSI because the levels are highly time-invariant and thus predictable. It is theoretically plausible that only new information about customer satisfaction, conveyed by changes in the ACSI, is a source of expectational errors. For this reason, we also consider the following model:

$$
F E_{i, t}=\alpha+\beta \Delta A C S I_{i, t-n-1}+\sum_{k=1}^{K} \gamma_{k} C_{k, i, t-n}+\varepsilon_{i, t}
$$

where $\triangle A C S I_{i, t-n-1}$ is the change in the ACSI score over the year preceding the analyst earnings forecasts for firm $i$. To test the theoretical claim that only changes in customer satisfaction reflect news that is misinterpreted by the financial market, we estimate the model in a matching set of regressions and report on the results in Table 4.4.

According to the results, the two-year price-scaled forecast error is positively related to changes in the ACSI, even after controlling for firms' book-to-market ratio and firm size. However, we find that none of the other model specifications provide evidence that changes in the ACSI relate positively to analyst forecast errors, including that for two-year asset-scaled forecast errors.

Taken as a whole, our analysis of earnings forecast errors suggests that analysts largely anticipate the implications of customer satisfaction for future operating performance. Yet, this result is not entirely robust across all model specifications. In addition, while analysts' expectations are good proxies for investors' expectations, they nevertheless do not directly capture errors in investors' expectations and their consequences for abnormal stock returns. We therefore complement this analysis with a more direct test of errors in the financial market's expectations, in the next section of this study. 


\section{TABLE 4.3}

\section{Customer satisfaction and earnings forecast errors}

This table shows results for pooled OLS regressions of earnings forecast errors on customer satisfaction. Earnings forecast errors are measured as the difference between actual earnings and the consensus of earnings forecasts by financial analysts, which we compute for one-year (1-yr FE), two-year (2-yr FE), and long-term earnings growth (LTG) forecasts. Following prior research, the one- and two-year forecast errors are respectively scaled by the lagged stock price or book assets to control for heteroskedasticity. Customer satisfaction is measured by the ACSI score, and the regressions include controls for the book-to-market ratio (logBME), market value of equity (logMVE) as well as year fixed effects. All explanatory variables are measured before the issuance of the respective analyst earnings forecasts. Robust $t$-statistics with standard errors that are clustered at both the firm and year level are reported in parentheses.

\begin{tabular}{|c|c|c|c|c|c|c|c|c|c|c|}
\hline & $\begin{array}{l}\text { 1-yr FE } \\
\text { / Price }\end{array}$ & $\begin{array}{l}\text { 1-yr FE } \\
\text { / Price }\end{array}$ & $\begin{array}{l}\text { 1-yr FE } \\
\text { / Assets }\end{array}$ & $\begin{array}{l}\text { 1-yr FE } \\
\text { / Assets }\end{array}$ & $\begin{array}{l}\text { 2-yr FE } \\
\text { / Price }\end{array}$ & $\begin{array}{l}\text { 2-yr FE } \\
\text { / Price }\end{array}$ & $\begin{array}{l}\text { 2-yr FE } \\
\text { / Assets }\end{array}$ & $\begin{array}{l}\text { 2-yr FE } \\
\text { / Assets }\end{array}$ & LTG & LTG \\
\hline ACSI & $\begin{array}{l}0.0001 \\
(0.54)\end{array}$ & $\begin{array}{l}0.0000 \\
(-0.09)\end{array}$ & $\begin{array}{l}0.0000 \\
(-0.28)\end{array}$ & $\begin{array}{l}-0.0001 \\
(-0.81)\end{array}$ & $\begin{array}{l}0.0005 \\
(1.01)\end{array}$ & $\begin{array}{l}0.0005 \\
(0.91)\end{array}$ & $\begin{array}{l}0.0000 \\
(0.12)\end{array}$ & $\begin{array}{l}0.0002 \\
(1.06)\end{array}$ & $\begin{array}{l}0.0011 \\
(0.47)\end{array}$ & $\begin{array}{l}0.0027 \\
(1.14)\end{array}$ \\
\hline $\log \mathrm{BME}$ & & $\begin{array}{l}-0.0015 \\
(-1.57)\end{array}$ & & $\begin{array}{l}-0.0003 \\
(-0.39)\end{array}$ & & $\begin{array}{l}0.0001 \\
(0.08)\end{array}$ & & $\begin{array}{l}0.0025 \\
(1.44)\end{array}$ & & $\begin{array}{l}0.0278 * \\
(1.84)\end{array}$ \\
\hline logMVE & & $\begin{array}{l}-0.0003 \\
(-0.57)\end{array}$ & & $\begin{array}{l}0.0004 \\
(0.72)\end{array}$ & & $\begin{array}{l}0.0020 \\
(1.09)\end{array}$ & & $\begin{array}{l}0.0009 \\
(0.73)\end{array}$ & & $\begin{array}{l}0.0156 \\
(1.57)\end{array}$ \\
\hline Year Fixed Effects & Yes & Yes & Yes & Yes & Yes & Yes & Yes & Yes & Yes & Yes \\
\hline Adj. R-squared & 0.01 & 0.01 & 0.01 & 0.01 & 0.02 & 0.02 & 0.02 & 0.03 & 0.05 & 0.07 \\
\hline \# Observations & 736 & 736 & 808 & 808 & 626 & 626 & 692 & 692 & 421 & 421 \\
\hline
\end{tabular}

$* * * \mathrm{p} \leq 0.01, * * \mathrm{p} \leq 0.05, * \mathrm{p} \leq 0.1$

Robust $t$-statistics reported in parentheses.

Standard errors are heteroskedasticity robust and clustered at both firm and year level. 


\section{TABLE 4.4}

\section{Changes in customer satisfaction and earnings forecast errors}

This table shows results for pooled OLS regressions of analyst forecast errors on changes in customer satisfaction. Earnings forecast errors are measured as the difference between actual earnings and the consensus of earnings forecasts by financial analysts, which we compute for one-year (1-yr FE), two-year (2-yr FE), and long-term earnings growth (LTG) forecasts. Following prior research, the one- and two-year forecast errors are respectively scaled by the lagged stock price or book assets to control for heteroskedasticity. Customer satisfaction is measured as the percentage change in the ACSI score over the year preceding the analyst earnings forecasts. The regressions include controls for the book-to-market ratio $\left(\operatorname{logBME} \mathrm{E}_{\mathrm{t}-1}\right)$, market value of equity $\left(\log \mathrm{MVE}_{\mathrm{t}-1}\right)$ as well as year fixed effects. All explanatory variables are measured before the issuance of the respective analyst earnings forecasts. Robust $t$-statistics with standard errors that are clustered at the firm and year level are reported in parentheses.

\begin{tabular}{|c|c|c|c|c|c|c|c|c|c|c|}
\hline & $\begin{array}{l}\text { 1-yr FE } \\
\text { / Price }\end{array}$ & $\begin{array}{l}\text { 1-yr FE } \\
\text { / Price }\end{array}$ & $\begin{array}{l}\text { 1-yr FE } \\
\text { / Assets }\end{array}$ & $\begin{array}{l}\text { 1-yr FE } \\
\text { / Assets }\end{array}$ & $\begin{array}{l}\text { 2-yr FE } \\
\text { / Price }\end{array}$ & $\begin{array}{l}\text { 2-yr FE } \\
\text { / Price }\end{array}$ & $\begin{array}{l}\text { 2-yr FE } \\
\text { / Assets }\end{array}$ & $\begin{array}{l}\text { 2-yr FE } \\
\text { / Assets }\end{array}$ & LTG & LTG \\
\hline$\Delta \mathrm{ACSI}$ & $\begin{array}{l}0.0073 \\
(1.11)\end{array}$ & $\begin{array}{l}0.0066 \\
(0.69)\end{array}$ & $\begin{array}{l}0.0072 \\
(0.80)\end{array}$ & $\begin{array}{l}0.0077 \\
(0.84)\end{array}$ & $\begin{array}{l}0.0562^{* * *} \\
(2.26)\end{array}$ & $\begin{array}{l}0.0604^{* *} \\
(2.17)\end{array}$ & $\begin{array}{l}0.0270 \\
(1.33)\end{array}$ & $\begin{array}{l}0.0296 \\
(1.54)\end{array}$ & $\begin{array}{l}0.0394 \\
(0.44)\end{array}$ & $\begin{array}{l}0.0636 \\
(0.90)\end{array}$ \\
\hline $\log \mathrm{BME}$ & & $\begin{array}{l}-0.0012 \\
(-1.01)\end{array}$ & & $\begin{array}{l}0.0001 \\
(0.12)\end{array}$ & & $\begin{array}{l}-0.0010 \\
(-0.53)\end{array}$ & & $\begin{array}{l}0.0022 \\
(1.28)\end{array}$ & & $\begin{array}{l}0.0253 * * \\
(2.15)\end{array}$ \\
\hline logMVE & & $\begin{array}{l}-0.0001 \\
(-0.10)\end{array}$ & & $\begin{array}{l}0.0006 \\
(1.19)\end{array}$ & & $\begin{array}{l}0.0022 \\
(1.18)\end{array}$ & & $\begin{array}{l}0.0013 \\
(0.89)\end{array}$ & & $\begin{array}{l}0.0176 * \\
(1.79)\end{array}$ \\
\hline Year Fixed Effects & Yes & Yes & Yes & Yes & Yes & Yes & Yes & Yes & Yes & Yes \\
\hline Adj. R-squared & 0.01 & 0.01 & 0.02 & 0.02 & 0.01 & 0.02 & 0.03 & 0.04 & 0.07 & 0.09 \\
\hline \# Observations & 690 & 690 & 761 & 761 & 590 & 590 & 655 & 655 & 396 & 396 \\
\hline
\end{tabular}

$* * * \mathrm{p} \leq 0.01, * * \mathrm{p} \leq 0.05, * \mathrm{p} \leq 0.1$

Robust $t$-statistics reported in parentheses.

Standard errors are heteroskedasticity robust and clustered at both firm and year level. 


\subsubsection{Customer satisfaction and earnings announcement returns}

The most direct test of investors' expectational errors is an analysis of the relation between stock market responses to firms' earnings announcements and customer satisfaction. If customer satisfaction surprises investors, thus subsequently causing them to revise their expectations of future earnings, we should observe a significant relation between customer satisfaction and stock prices changes when these surprises materialize in the market. That is, we expect investors to revise their expectations subsequent to firms' earnings announcements, leading to changes in stock prices and thereby causing abnormal returns during days around earnings announcements. Under the errors-in-expectations hypothesis, abnormal returns on trading strategies that seek to exploit mispricing of customer satisfaction should be significantly positively related to these earnings announcements returns.

For each firm in our sample, we collect quarterly earnings announcement dates from the Compustat library, and perform a standard event study to measure stock price reactions on and around these dates. Given that prior research does not prescribe a time horizon over which earnings announcement returns materialize, we consider various event windows: 1 day before until 1 day after, 3 days before until 3 days after, 5 days before until 5 days after, and 10 days before until 10 days after the earnings announcement. To test for the presence of systematic earnings announcement effects, we rely on both excess (i.e., in excess of the risk-free rate) and abnormal (i.e., risk-adjusted) stock returns.

For each day that we consider within an event window, the abnormal return on a firm's stock is defined as the difference between its realized return and its expected return as predicted by the Carhart (1997) four-factor model:

$$
A R_{i, t}=R_{i, t}-E\left(R_{i, t}\right)
$$

where

$$
E\left(R_{i, t}\right)=R_{f, t}+\beta_{1, i}\left(R_{m, t}-R_{f, t}\right)+\beta_{2, i} S M B+\beta_{3, i} H M L+\beta_{4, i} W M L+\varepsilon_{i, t}
$$

and where $R_{f, t}$ is the Ibbotson 30-day T-bill rate, $R_{m, t}$ is the return on a value-weighted portfolio of all NYSE-AMEX-Nasdaq stocks, $S M B_{t}$ is the return difference between a smallcap stock portfolio and a large-cap stock portfolio, $H M L_{t}$ is the return difference between a high book-to-market stock portfolio and a low book-to-market stock portfolio, and $W M L_{t}$ is the return difference between a stock portfolio with high past returns and a stock portfolio with low past returns. Carhart (1997) provides details on the construction and interpretation of the four factors. We collect daily four-factor returns and the T-bill rate from the Kenneth French Data Library to calculate expected returns. ${ }^{34}$ The factor sensitivities $\beta_{1, i}, \beta_{2, i}, \beta_{3, i}$, and $\beta_{4, i}$ are estimated for each firm before every earnings announcement, using stock returns observed over a 250-day period that ends 20 days before the announcement date.

Prior research has used different portfolio formation techniques to assess the long-term abnormal return performance of ACSI-based investment strategies. In our test for abnormal earnings announcement returns following the release of ACSI, we form portfolios based on the three most commonly used approaches. First, we rank firms in each quarter according to their

\footnotetext{
${ }^{34}$ http://mba.tuck.dartmouth.edu/pages/faculty/ken.french/
} 
ACSI scores and form five portfolios consistent with the quintile formation approach of Fornell et al. (2006) and O'Sullivan et al. (2009). Quintile 5 covers firms with the highest ACSI scores, and Quintile 1 those with the lowest ACSI scores. Second, we rank firms in each quarter according to the magnitude of a percentage change in the ACSI and again allocate them to one of five quintiles portfolios (Ittner et al., 2009). Quintile 5, in this approach, represents firms that display the largest increase in the ACSI. Finally, we analyze earnings announcement returns for firms that display both above average and increasing (below average and decreasing) values of the ACSI, which is consistent with the portfolio approach advocated by Aksoy et al. (2008). In keeping with this approach, we base both portfolios on ACSI scores that are scaled by the ACSI national average score, which is intended to remove the impact of systematic economy wide sentiment changes.

Following the formation of the ACSI portfolios, we measure daily average excess returns (i.e., in excess of the risk-free rate) and cumulative abnormal returns (CAR) around the earnings announcement dates of each firm. The CAR is defined as the sum of daily abnormal returns measured over a particular event window. Both of the return measures are estimated over the aforementioned event windows, and then respectively aggregated within each ACSI portfolio using equal weights. ${ }^{35}$

Tables 4.5 and 4.6 summarize the results for event studies on the ACSI level- and changebased quintile portfolios. We report earnings announcement returns for the different event windows and their respective quintile portfolios, along with $t$-statistics. In addition, we show the difference in earnings announcement returns for Quintile 5 and Quintile 1 together with the corresponding $t$-statistics.

If customer satisfaction is a pervasive source of errors in investors' expectations, then we expect to find a significant cross-sectional variation in the earnings announcement CARs. If investors misunderstand the positive implications of improved customer satisfaction for future earnings then we should observe that CAR around earnings announcement dates increases with quintile rank.

For the quintile portfolios based on ACSI levels, reported in Table 4.5, we find no such variation in CAR. None of the quintiles earns average abnormal returns around earnings announcements that are statistically significant, independent of the event window that we investigate. An identical message emerges from forming quintiles based on ACSI changes. Table 4.6 shows that cumulative abnormal returns on these quintile portfolios are not significantly clustered around earnings announcement dates.

\footnotetext{
${ }^{35}$ The test results for value-weighted earnings announcement returns are very similar to those presented in this paper. While these results are not reported for brevity, they are readily available on request.
} 


\section{TABLE 4.5}

\section{Customer satisfaction and abnormal earnings announcement returns}

This table summarizes the results of an event study on the relation between customer satisfaction and stock price reactions around earnings announcements. We form quintile portfolios based on ACSI scores and measure both equal-weighted average excess returns (i.e., in excess of the risk-free rate) and cumulative abnormal returns (CAR) around the earnings announcement dates of each firm. Column 1 lists the different event windows over which these returns are calculated, together with their corresponding quintile portfolios. We examine 3-day, 7-day, 11day, and 21-day event windows that are centered on the earnings announcement date. Quintile 5 contains earnings announcement returns for firms with the highest ACSI scores, and Quintile 1 those with the lowest ACSI scores.

\begin{tabular}{|c|c|c|c|c|c|}
\hline ACSI Quintiles & Excess Return & $t$-stat & CAR & $t$-stat & \# Obs. \\
\hline \multicolumn{6}{|c|}{ window $(-1,1)$} \\
\hline 5 & $0.09 \%$ & 0.96 & $0.10 \%$ & 0.47 & 757 \\
\hline 4 & $0.03 \%$ & 0.37 & $0.01 \%$ & 0.04 & 681 \\
\hline 3 & $0.17 \%$ & $1.76^{*}$ & $0.33 \%$ & 1.23 & 575 \\
\hline 2 & $0.14 \%$ & 1.64 & $0.22 \%$ & 0.96 & 694 \\
\hline 1 & $0.01 \%$ & 0.09 & $-0.15 \%$ & -0.51 & 559 \\
\hline $5-1$ & $0.08 \%$ & 0.59 & $0.25 \%$ & 0.49 & 559 \\
\hline \multicolumn{6}{|c|}{ window $(-3,3)$} \\
\hline 5 & $0.06 \%$ & 1.18 & $0.04 \%$ & 0.15 & 757 \\
\hline 4 & $0.09 \%$ & $2.03 * *$ & $0.24 \%$ & 0.91 & 681 \\
\hline 3 & $0.10 \%$ & $2.14 * *$ & $0.38 \%$ & 1.56 & 575 \\
\hline 2 & $0.09 \%$ & $1.75^{*}$ & $0.38 \%$ & 1.23 & 694 \\
\hline 1 & $0.04 \%$ & 0.58 & $-0.25 \%$ & -0.61 & 559 \\
\hline $5-1$ & $0.02 \%$ & 0.83 & $0.29 \%$ & 0.54 & 559 \\
\hline \multicolumn{6}{|c|}{ window $(-5,5)$} \\
\hline 5 & $0.08 \%$ & $2.11 *$ & $0.23 \%$ & 0.74 & 757 \\
\hline 4 & $0.09 \%$ & $2.92 * * *$ & $0.21 \%$ & 0.76 & 681 \\
\hline 3 & $0.09 \%$ & $2.46 * *$ & $0.43 \%$ & 1.47 & 575 \\
\hline 2 & $0.09 \%$ & $1.95 *$ & $0.28 \%$ & 0.75 & 559 \\
\hline 1 & $0.04 \%$ & 0.85 & $-0.21 \%$ & -0.41 & 559 \\
\hline $5-1$ & $0.04 \%$ & 0.52 & $0.45 \%$ & 0.46 & 559 \\
\hline \multicolumn{6}{|c|}{ window $(-10,10)$} \\
\hline 5 & $0.10 \%$ & $3.52 * * *$ & $0.65 \%$ & 1.48 & 757 \\
\hline 4 & $0.06 \%$ & $2.38 * *$ & $-0.22 \%$ & -0.58 & 681 \\
\hline 3 & $0.07 \%$ & $2.61 * * *$ & $0.29 \%$ & 0.67 & 575 \\
\hline 2 & $0.08 \%$ & $2.56^{* *}$ & $0.44 \%$ & 0.95 & 694 \\
\hline 1 & $0.07 \%$ & $2.15 * *$ & $-0.31 \%$ & -0.54 & 559 \\
\hline $5-1$ & $0.03 \%$ & 0.44 & $0.96 \%$ & 0.19 & 559 \\
\hline
\end{tabular}

$* * * \mathrm{p} \leq 0.01, * * \mathrm{p} \leq 0.05, * \mathrm{p} \leq 0.1$ 


\section{TABLE 4.6}

\section{Changes in customer satisfaction and abnormal earnings announcement returns}

This table summarizes the results of an event study on the relation between changes in customer satisfaction and subsequent stock price reactions around earnings announcements. We form quintile portfolios based on the magnitude of a percentage change in the ACSI scores, and measure equal-weighted average excess returns (i.e., in excess of the risk-free rate) as well as cumulative abnormal returns (CAR) around the earnings announcement dates of each firm. Column 1 lists the different event windows over which these returns are calculated, together with their corresponding quintile change portfolios. We examine 3-day, 7-day, 11-day, and 21-day event windows that are centered on the earnings announcement date. Quintile 5 contains earnings announcement returns for firms with the largest change in ACSI scores and Quintile 1 those with the smallest change ACSI scores.

\begin{tabular}{|c|c|c|c|c|c|}
\hline$\triangle$ ACSI Quintiles & Excess Return & $t$-stat & CAR & $t$-stat & \# Obs. \\
\hline \multicolumn{6}{|l|}{ window $(-1,1)$} \\
\hline 5 & $0.07 \%$ & 0.67 & $0.06 \%$ & 0.24 & 685 \\
\hline 4 & $0.14 \%$ & $1.72 *$ & $0.21 \%$ & 1.08 & 784 \\
\hline 3 & $0.18 \%$ & $1.71 *$ & $0.31 \%$ & 0.97 & 268 \\
\hline 2 & $0.09 \%$ & 1.09 & $0.10 \%$ & 0.42 & 840 \\
\hline 1 & $0.02 \%$ & 0.19 & $-0.06 \%$ & -0.27 & 689 \\
\hline $5-1$ & $0.05 \%$ & 0.70 & $0.12 \%$ & 0.72 & 685 \\
\hline \multicolumn{6}{|l|}{ window $(-3,3)$} \\
\hline 5 & $0.06 \%$ & 0.98 & $0.12 \%$ & 0.37 & 685 \\
\hline 4 & $0.10 \%$ & $2.12 * *$ & $0.32 \%$ & 1.30 & 784 \\
\hline 3 & $0.09 \%$ & 1.47 & $0.07 \%$ & 0.16 & 268 \\
\hline 2 & $0.08 \%$ & $1.82 *$ & $0.18 \%$ & 0.69 & 840 \\
\hline 1 & $0.06 \%$ & 0.99 & $-0.04 \%$ & -0.11 & 689 \\
\hline $5-1$ & $0.00 \%$ & 0.98 & $0.15 \%$ & 0.74 & 685 \\
\hline \multicolumn{6}{|l|}{ window $(-5,5)$} \\
\hline 5 & $0.08 \%$ & $1.70 *$ & $0.20 \%$ & 0.47 & 685 \\
\hline 4 & $0.09 \%$ & $2.43 * *$ & $0.28 \%$ & 0.92 & 784 \\
\hline 3 & $0.10 \%$ & $2.06 * *$ & $0.34 \%$ & 0.68 & 268 \\
\hline 2 & $0.07 \%$ & $2.01 * *$ & $0.20 \%$ & 0.64 & 840 \\
\hline 1 & $0.07 \%$ & 1.52 & $-0.01 \%$ & -0.02 & 689 \\
\hline $5-1$ & $0.01 \%$ & 0.86 & $0.21 \%$ & 0.73 & 685 \\
\hline \multicolumn{6}{|l|}{ window $(-10,10)$} \\
\hline 5 & $0.07 \%$ & $2.35 * *$ & $-0.04 \%$ & -0.09 & 685 \\
\hline 4 & $0.10 \%$ & $3.69 * * *$ & $0.32 \%$ & 1.02 & 784 \\
\hline 3 & $0.08 \%$ & $2.73 * * *$ & $0.18 \%$ & 0.30 & 268 \\
\hline 2 & $0.06 \%$ & $2.33 * *$ & $-0.10 \%$ & -0.25 & 840 \\
\hline 1 & $0.08 \%$ & $2.52 * *$ & $0.08 \%$ & 0.15 & 689 \\
\hline $5-1$ & $-0.01 \%$ & 0.85 & $-0.13 \%$ & -0.86 & 685 \\
\hline
\end{tabular}

$* * * \mathrm{p} \leq 0.01, * * \mathrm{p} \leq 0.05, * \mathrm{p} \leq 0.1$ 
The study that documents the strongest long-term abnormal returns to trading strategies using the ACSI forms stock portfolios based on both the level of the ACSI and the change in the ACSI. Aksoy et al (2008) report a significant positive abnormal stock return for a portfolio of firms that display both high levels of the ACSI and positive changes, and interpret this as evidence that the market does not fully understand the implications of strong and better customer satisfaction for firm performance. Table 4.7 shows whether abnormal returns on quintiles formed based on ACSI levels and changes are clustered around earnings announcements. Earlier evidence that such a portfolio formation rule translates into long-term abnormal returns is not supported by tests of earnings announcement returns. We find that neither stocks with high and increasing levels of ACSI nor stocks with low and decreasing levels of ACSI earn statistically significant CAR around earnings announcements, which does not support the errors in expectations story suggested by Aksoy et al. (2008). ${ }^{36}$

We can also derive how large long-term abnormal returns on customer satisfaction-based trading strategies are, provided that these earnings announcements are the sole events underlying abnormal returns in the long-run. To illustrate, the earnings announcement return for the group of firms with high and increasing levels of ACSI is a statistically insignificant $0.48 \%$ higher than that of firms with low and decreasing levels of ACSI, according to the (10,10) value-weighted CARs that are reported in Table 4.A2. Annualized, this difference equals $1.92 \%$, which contrasts sharply with the $10.56 \%$ four-factor alpha that Aksoy et al. (2008) find for a corresponding difference portfolio. A standard $t$-test, not tabulated here for the sake of brevity, confirms that the long-term abnormal return implied by our CARs differs significantly from the annual abnormal return that are reported in earlier studies. This test illustrates that the abnormal returns implied by our explicit errors-in-expectations tests only cover a very limited fraction (i.e., 18\%) of the economically large abnormal returns documented in Aksoy et al. (2008). It also highlights the need for explanations other than errors-in-expectations to justify such large abnormal returns.

Given that stock market responses to earnings announcements are not different for firms with the highest ACSI (changes) compared to those for firms with the lowest ACSI (changes), we are unable to reject Hypothesis 3 that ACSI information does not cause expectational errors that lead to abnormal stock returns.

\footnotetext{
${ }^{36}$ Aksoy et al. (2008) report abnormal returns on portfolios that are value-weighted, but comment that their conclusions are unaffected by an equal weighting of the portfolios. For consistency, we nevertheless also report abnormal returns based on value-weighted portfolios in Table A2 of the Appendix. Note that only the CARs for the $(-10,10)$ event window are statistically significant, and in contrast to Aksoy et al., this significance is limited to firms with low and decreasing customer satisfaction levels.
} 


\section{TABLE 4.7}

\section{Levels \& changes in ACSI and abnormal earnings announcement returns}

This table summarizes the results of an event study on the relation between the combined information contained in ACSI levels as well as changes and stock price reactions around earnings announcements. We form two portfolios: High denotes a portfolio of firms that have above average ACSI scores while also experiencing positive changes in ACSI. Low denotes a portfolio of firms that have below average ACSI scores while also experiencing negative changes in ACSI. Note that these portfolios are constructed based on ACSI scores that are scaled by the national average ACSI score. For each portfolio we report equal-weighted average excess returns (i.e., in excess of the riskfree rate) as well as cumulative abnormal returns (CAR) that are measured around the earnings announcement dates of each firm. Column 1 lists the different event windows over which these returns are calculated, together with their corresponding ACSI portfolios. We examine 3-day, 7-day, 11-day, and 21-day event windows that are centered on the earnings announcement date. The null hypothesis is that the combined information on customer satisfaction levels and changes of firms does not result in significant abnormal returns on the days surrounding the release of earnings statements.

\begin{tabular}{cclllr}
\hline \hline ACSI High vs. Low & Excess Return & $t$-stat & CAR & $t$-stat & \# Obs. \\
\hline window (-1, 1) & & & & & \\
\hline High & $0.09 \%$ & 1.10 & $0.16 \%$ & 0.75 & 1,123 \\
Low & $0.11 \%$ & $1.78^{*}$ & $0.17 \%$ & 1.19 & 1,372 \\
High - Low & $-0.02 \%$ & 0.87 & $-0.01 \%$ & 0.96 & 1,123 \\
window (-3,3) & & & & & \\
\hline High & $0.07 \%$ & $1.74^{*}$ & $0.13 \%$ & 0.66 & 1,123 \\
Low & $0.08 \%$ & $2.01^{* *}$ & $0.23 \%$ & 1.06 & 1,372 \\
High - Low & $-0.01 \%$ & 0.82 & $-0.10 \%$ & 0.74 & 1,123 \\
window (-5, 5) & & & & & \\
\hline High & $0.09 \%$ & $2.51^{* * *}$ & $0.23 \%$ & 0.84 & 1,123 \\
Low & $0.08 \%$ & $2.60^{* * *}$ & $0.24 \%$ & 0.91 & 1,372 \\
High - Low & $0.00 \%$ & 0.92 & $-0.01 \%$ & 0.98 & 1,123 \\
window (-10, 10) & & & & & \\
\hline High & $0.08 \%$ & $3.17^{* * *}$ & $0.07 \%$ & 0.21 & 1,123 \\
Low & $0.07 \%$ & $2.83^{* * *}$ & $0.01 \%$ & 0.02 & 1,372 \\
High - Low & $0.01 \%$ & 0.72 & $0.06 \%$ & 0.90 & 1,123 \\
\hline
\end{tabular}

$* * * \mathrm{p} \leq 0.01, * * \mathrm{p} \leq 0.05, * \mathrm{p} \leq 0.1$ 


\subsection{Conclusion}

Previous studies have not yet reached a consensus about whether investors fully anticipate the implications that customer satisfaction has for the ability of firms to generate cash flows. Unfortunately, the empirical tests that these studies have proposed for this hypothesis revolve only around the relation between customer satisfaction and short-term and long-term abnormal stock returns. However, it is well known that stock returns may be generated by factors other than mispricing, such as an unknown risk factor that drives returns in an efficient market and happens to be correlated with customer satisfaction, or various sample biases.

Under the errors-in-expectations hypothesis, a causal linkage between abnormal returns and customer satisfaction should emerge only when investors do not anticipate the relation between customer satisfaction and firm's future earnings. These errors in expectations by investors have not explicitly been tested in the literature to date. In this study, we add new insights to the debate about the stock markets' pricing of customer satisfaction by focusing explicitly on measures of errors in investors' expectations of future earnings, and the implications of these errors for abnormal stock returns.

Using analysts' earnings forecasts and stock returns around firms' earnings announcements as proxies for investors' errors in expectations, we find that expectational errors cannot be attributed to customer satisfaction. While customer satisfaction is positively associated with future operating cash flows, neither analyst forecast errors nor earnings announcement returns convincingly suggest that this relation is unexpected by the financial market. Consequently, our evidence points away from the idea that errors in expectations cause firms with strong customer satisfaction to experience anomalously positive returns in the stock market.

We note that from a practical standpoint our conclusion does not mean that firms should not assign much importance to customer satisfaction. To the contrary, while mispricing would have implied that equity investors can make abnormal trading profits using information about customer satisfaction, exactly this mispricing would encourage managers to underinvest in customer satisfaction because, then, only in the long run would it pay off to shareholders.

As this study points out, a framework that deepens our understanding of investors' reaction to information about marketing assets and actions that influence firms' cash flows is critical to an adequate interpretation of stock market returns. The analytical framework that we propose in this study should be valuable for investigating the nature of other stock return anomalies that might be documented in the marketing literature as a result of the growing attention for the marketing-finance interface. Srinivasan and Hanssens (2009) provide interesting examples of marketing actions and asset metrics that might lend support to the errors-in-expectations hypothesis. Whether the cash flow implications of these marketing aspects are understood by investors is an interesting empirical question that awaits further research. 


\section{A Appendix}

TABLE 4.A1: Variable definitions

This table provides descriptions of the variables that are used in our analysis. Column 1 lists variable names and their components. Column 2 provides the corresponding variable definitions, and Column 3 reports the data sources from which we collect the information.

\begin{tabular}{|c|c|c|}
\hline Variable Name & Description & Database \\
\hline ACSI & The American Customer Satisfaction Index. & www.theacsi.org \\
\hline Forecast error (1-\& 2-yr) & Actual earnings per share (EPS) minus forecast EPS (mean consensus estimate). & $\mathrm{I} / \mathrm{B} / \mathrm{E} / \mathrm{S}$ \\
\hline Forecast error/price & Forecast error scaled by price at previous year-end. & $\mathrm{I} / \mathrm{B} / \mathrm{E} / \mathrm{S}$ \\
\hline Forecast error/assets & Forecast error scaled by year-end total assets per share. & $\mathrm{I} / \mathrm{B} / \mathrm{E} / \mathrm{S}$ \\
\hline Forecast error (long-term growth forecast) & $\begin{array}{l}\text { Actual annualized growth in earnings per share minus median forecast of long-term growth } \\
\text { in earnings per share, expressed in decimals. }\end{array}$ & $\mathrm{I} / \mathrm{B} / \mathrm{E} / \mathrm{S}$ \\
\hline Number of analyst forecasts & $\begin{array}{l}\text { Number of analysts with an earnings per share forecast outstanding 8, 20, or } 56 \text { month } \\
\text { before the actual EPS is reported. }\end{array}$ & $\mathrm{I} / \mathrm{B} / \mathrm{E} / \mathrm{S}$ \\
\hline Dispersion of analyst forecasts & Standard deviation of analysts' forecasts divided by the mean consensus forecast. & $\mathrm{I} / \mathrm{B} / \mathrm{E} / \mathrm{S}$ \\
\hline Earnings announcement returns & $\begin{array}{l}\text { Cumulative abnormal or excess return for a t-day window surrounding a quarterly earnings } \\
\text { announcement. }\end{array}$ & \\
\hline Daily stock returns & Holding period return minus the Ibbotson one-month Treasury bill rate. & CRSP \\
\hline$R m-R f, S M L, H M L, U M D$ & Fama/French Factors + Carhart Momentum Factor & K. R. French Data Library \\
\hline Quarterly earnings announcement dates & Report date of quarterly earnings. & Compustat NA \\
\hline Return on Assets (ROA) & Operating income before depreciation divided by total assets. & Compustat NA \\
\hline Total Assets & Book value of assets. & Compustat NA \\
\hline Market value of equity & $\begin{array}{l}\text { Outstanding shares at the end of the fiscal year multiplied by the share price at the end of } \\
\text { the fiscal year. }\end{array}$ & Compustat NA \\
\hline Book-to-market equity & $\begin{array}{l}\text { Book value of equity plus book value of deferred taxes, divided by the market value of } \\
\text { equity. }\end{array}$ & Compustat NA \\
\hline
\end{tabular}


TABLE 4.A2

Levels \& changes in ACSI and value-weighted abnormal earnings announcement returns

This table summarizes the results of an event study on the relation between the combined information contained in ACSI levels as well as changes and stock price reactions around earnings announcements. We form two portfolios: High denotes a portfolio of firms that have above average ACSI scores while also experiencing positive changes in ACSI. Low denotes a portfolio of firms that have below average ACSI scores while also experiencing negative changes in ACSI. Note that these portfolios are constructed based on ACSI scores that are scaled by the national average ACSI score. For each portfolio we report value-weighted average excess returns (i.e., in excess of the riskfree rate) as well as cumulative abnormal returns (CAR) that are measured around the earnings announcement dates of each firm. Column 1 lists the different event windows over which these returns are calculated, together with their corresponding ACSI portfolios. We examine 3-day, 7-day, 11-day, and 21-day event windows that are centered on the earnings announcement date. The null hypothesis is that the combined information on customer satisfaction levels and changes of firms does not result in significant abnormal returns on the days surrounding the release of earnings statements.

\begin{tabular}{crlllr}
\hline \hline ACSI High vs. Low & Excess Return & $t$-stat & CAR & $t$-stat & \# Obs. \\
\hline window (-1, 1) & & & & & \\
\hline High & $-0.01 \%$ & -0.12 & $-0.18 \%$ & -0.68 & 1,123 \\
Low & $0.12 \%$ & $1.74^{*}$ & $0.06 \%$ & 0.30 & 1,372 \\
High - Low & $-0.13 \%$ & 0.33 & $-0.25 \%$ & 0.47 & 1,123 \\
window (-3, 3) & & & & & \\
\hline High & $0.04 \%$ & 0.63 & $-0.24 \%$ & -0.65 & 1,123 \\
Low & $0.09 \%$ & $1.94^{*}$ & $0.06 \%$ & 0.23 & 1,372 \\
High - Low & $-0.05 \%$ & 0.52 & $-0.30 \%$ & 0.51 & 1,123 \\
window (-5, 5) & & & & & \\
\hline High & $0.06 \%$ & 1.55 & $-0.11 \%$ & -0.26 & 1,123 \\
Low & $0.07 \%$ & $1.95^{*}$ & $-0.13 \%$ & -0.49 & 1,372 \\
High - Low & $0.00 \%$ & 0.99 & $0.02 \%$ & 0.96 & 1,123 \\
window (-10, 10) & & & & & \\
\hline High & $0.06 \%$ & $2.01^{* *}$ & $-0.50 \%$ & -0.99 & 1,123 \\
Low & $0.04 \%$ & $1.71^{*}$ & $-0.98 \%$ & $-2.68 * * *$ & 1,372 \\
High - Low & $0.01 \%$ & 0.72 & $0.48 \%$ & 0.44 & 1,123 \\
\hline
\end{tabular}

$* * * \mathrm{p} \leq 0.01, * * \mathrm{p} \leq 0.05, * \mathrm{p} \leq 0.1$ 


\section{Chapter 5}

\section{Customer Relationships and Financial Policy: The role of customer claims in capital structure decisions*}

This chapter explores whether customer claims affect the financial decision making of firms. Stakeholder theory suggests that the success of customer-based strategies depends on the ability and willingness of management to deliver on the promises that it sells to customers. We examine whether firms that are committed to honoring customer claims certify their commitment by adopting more conservative financial policies. I use customer satisfaction as a proxy for the commitment to customer claims and confirm that firms with higher customer satisfaction levels hold less debt in their capital structure. We conclude that firms have corporate financial policies that are consistent with their customer relationship policies.

\subsection{Introduction}

There is growing understanding among researchers from various disciplines that firms can reap economic benefits from managing their relationships with non-financial stakeholders, such as customers, suppliers, and employees. ${ }^{37}$ Of these disciplines, the field of marketing has played a fundamental role in helping managers understand the factors that influence a firm's relationships with stakeholders and how these relationships affect firm performance. For example, according to Dwyer et al. (1987, p.12): “...both business marketing and consumer marketing benefit from attention to conditions that foster relational bonds leading to reliable repeat business."

While it is fundamental to marketing science to understand of how marketing strategies contribute to the strengthening of relationships between a firm and its key stakeholders, there is a limited understanding of how a credible commitment to such relationships should be factored into a firm's financial policy. The recent surge in studies on the link between marketing and finance has largely concentrated on financial outcomes of marketing actions and strategies. In this study, we hypothesize that stakeholder-related marketing strategies are an important

\footnotetext{
* This chapter is based on Derwall, Hann, and Verwijmeren (2011).

${ }^{37}$ Freeman, Harrison, Wicks, Parmar and Colle (2010) give an excellent summary of the ways that scholars in management, accounting, economics, and marketing either directly or indirectly address the relevance of these relationships through stakeholder theories.
} 
ingredient of corporate financial policy, as the credibility and the effectiveness of relationship commitment both depend on a firm's financial condition.

We focus on the relationship between the firm and one of its most prominent stakeholders: its customers. While recent research on the marketing-finance interface highlights that the identification and implementation of customer-based strategies can drive the financial performance of firms, these studies do not address whether the successful implementation of such strategies requires the adoption of a supportive financial policy. We suggests that marketing helps firms to maximize shareholder value by developing relations with customers only when strategic marketing goals constitute an integral part of the firm's overall financial policy.

Specifically, we propose that an important decision in signaling credible commitment to customers concerns the choice of financial leverage. The stakeholder theory of capital structure predicts that firms committed to strong relationships with stakeholders are relatively less levered to better ensure that their claims can be honored. When customers do business with a firm, they purchase several claims that can be affected by leverage. First, a high debt ratio increases the likelihood that customers face costs due to bankruptcy (e.g., Titman 1984), which leads to a breach of contractually determined claims. But even in the absence of financial distress, a higher leverage can signal that a firm has a lower likelihood of honoring the claims that customers purchase by entering into a relationship with the firm, particularly claims that are not contractual but implicit in the relation (see, e.g., Cornell and Shapiro 1987; Maksimovic and Titman 1991). Therefore, the hypothesis that we test in this study is that that firms striving for strong relationships with their customers adopt a financial policy that targets a conservative level of debt. A conservative capital structure policy is expected to increase the firm's ability to honor customer claims, and in turn increase the willingness of customers to invest in relationships with the firm.

To investigate whether commitment to customer claims affects firms' capital structure decisions, we use the American Customer Satisfaction Index (ACSI) as a proxy for the level of such a commitment. We conjecture that the ACSI constitutes an attractive measure of the commitment to customer claims, because it captures the firm's efforts and its success in fulfilling the expectations of customers. The ACSI is highly suitable for this study because it measures the quality of a firm's products and services through the lens of the customers that consume them (Fornell, Johnson, Anderson, Cha, and Bryant 1996). It captures the level of quality and reliability that is expected by customers, their post-purchase evaluation of the products and services, and their level of overall satisfaction as well as satisfaction relative to expectations. The ACSI also addresses repurchase likelihood and price tolerance in case of repurchase, which essentially constitutes customer's willingness to commit to the firm's product and services in the future. The ACSI thus overcomes many of the problems involving the measurement of a commitment to implicit claims, and the willingness of customers to engage in relationship-specific investments with the firm.

We study a sample of firms that are rated by the ACSI over the period 1995-2008, and document strong evidence that leverage rates are significantly negatively related to customer satisfaction levels. We find that a one-point increase in the ACSI is associated with a $0.6 \%$ decrease in book leverage, and a $1 \%$ decrease in market leverage. To further reinforce the conjecture that firms choose a capital structure that facilitates commitment to customer claims, we show that the ACSI explains equity and debt issue and repurchase decisions. Consistent with the stakeholder theory, firms with higher ACSI scores are less likely to issue debt than 
equity when they require external financing, and more likely to repurchase debt than equity in case of financing surplus. Our results also show that the documented leverage effect is robust to the effect of customer satisfaction on credit risk, which has been documented in earlier studies. Taken together, the results provide support for the theory that firms require an adequate financial policy to maximize the return on the claims generated by their marketing actions, and in order to prevent situations in which they are forced to renege upon claims, such as financial distress.

The remainder of the study is structured as follows. Section 2 outlines the theoretical framework. We discuss why credible commitment to customer claims plays an important role in the capital structure decisions of firms, introduce the measure of the firm's commitment to both explicit and implicit customer claims, and derive three testable hypotheses based on the stakeholder framework. Section 3 introduces the data that we use in the empirical analysis. Section 4 presents the results. Section 5 concludes this study.

\subsection{Theory and Hypothesis Development}

\subsubsection{Stakeholder theory and capital structure decisions}

Our theoretical framework draws on stakeholder theories that emerged from earlier finance, economics, and marketing literatures. For example, the marketing literature more and more propose that managers steer away from thinking about exchange with stakeholders as discrete events and more towards an ongoing relation-oriented view (see, e.g., Dwyer et al. 1987). The arguments regarding the benefits that firms can experience by such thinking include repeat business and ultimately better financial performance. The finance literature on stakeholder theory complements marketing theory when it comes to enhancing these relationships, and thereby constitutes an important element of the interface between marketing and finance.

Stakeholder theory of finance considers financial policy to be co-determined by stakeholders other than shareholders and bondholders, such as buyers and suppliers. The focus of our analysis is on customers as the primary source of income to the firm, and more specifically, the influence that their claims exert on the capital structure decisions of the firm.

According to Titman (1984), customers are concerned about the probability that a firm goes out of business because of the costs that they experience as a result of the liquidation. In response to this risk, customers are expected to lower their willingness to pay for a firm's products and services as its probability of default increases. Whereas the framework introduced by Titman focuses on the willingness to pay for durable goods as a function of the manufacturer's liquidation risk, Maksimovich and Titman (1991) extend this argument to consumers of non-durable goods. The authors point out that a higher debt ratio matters to consumers of non-durable goods, because it essentially conveys information about a firm's ability and incentive to invest in its reputation and deliver goods of high quality. Following this line of reasoning, firms that aim to increase customers' willingness to make firm-specific investments need to ensure and signal a stable financial conditions. An effective measure to achieve a credible reduction in default risk is the adoption of a conservative capital structure policy.

The empirical evidence suggests that customers indeed react to the financial health of firms along the lines suggested by the aforementioned studies. For example, Hammond (2010) derives from secondary market prices that the willingness to pay for Chrysler products declined 
by $4.4 \%$ following the announcement of financial distress in 1979. On a more aggregate level, Opler and Titman (1994) find that firms with higher levels of debt in their capital structure lose significant market share in times of industry downturns. Kale and Shahrur (2007) provide evidence that firms maintain lower leverage rates to induce suppliers and customers to undertake relationship-specific investments (e.g., R\&D), and engage in strategic alliances or joint ventures. Banerjee, Dasgupta, and Kim (2008) show that firms which produce or procure unique products are also likely to maintain a lower leverage rate, especially when they operate in durable goods industries.

Complementary to these arguments, and central to our analysis, is the stakeholder approach to financial policy that is advocated by Cornell and Shapiro (1987) and later by Zingales (2000). Here, it is particularly the probability that a firm reneges on its implicit agreements, which determines the willingness of customers to pay for products and services. Firms regularly issue implicit claims as an incentive for stakeholders to invest in firm-specific capital. Examples of this practice are the promises that customers receive about product and service quality; the continued supply of the offered product, spare parts, and support; as well as complementary products and product enhancements. Since these claims are neither legally binding nor independently tradable from the underlying goods and services, their expected payoff is uncertain even if the probability of financial distress or bankruptcy is low. ${ }^{38}$

Given the uncertainty surrounding implicit claims, customers are expected to adjust the premium that they are willing to pay for the firm's goods and services, depending on their perception of the ability and willingness of management to deliver on implicit promises. According to the framework of Cornell and Shapiro (1987), firms that sell implicit claims thus have an incentive to pursue a conservative capital structure so as to optimize the return on these claims, and to prevent any downside risk associated with breaching them. ${ }^{39}$

Because of the growing importance of implicit claims in modern businesses, researchers have suggested that a conservative financial policy improves the firm's reputation for honoring the implicit promises that it exchanges with key stakeholders. All of the arguments above suggest that choosing a lower debt ratio offers a credible mechanism for management to certify its commitment to current and future customer claims. A lower debt ratio signals a stronger position to secure stakeholder claims, which decreases the risk that customers bear when investing in relationships with the firm, and therefore increases their willingness to pay for products and services. It also ensures that the cost of honoring future claims is reduced.

\subsubsection{Measuring the commitment to customer claims}

The central challenge in an empirical test of the relation between customer claims and capital structure decisions is identifying the commitment of a firm to such claims. According to Dwyer et al (1987, p 19): "Commitment refers to an implicit or explicit pledge of relational continuity between exchange partners." They consider commitment the most advanced phase of buyerseller interdependence, "where the exchange partners have achieved a level of satisfaction from

\footnotetext{
${ }^{38}$ For example, if a firm faces a temporary liquidity constraint, it is more likely to renege on its implicit promises before violating any explicit agreements because only the latter are legally binding.

${ }^{39}$ While a failure to honor implicit claims does not give rise to legal repercussions, it can result in substantial reputational damage and a permanent loss in firm value (Cornell and Shapiro, 1987).
} 
the exchange process that virtually precludes other primary exchange partners who could provide similar benefits."

It stands to reason that a measure of commitment ideally integrates information on both the implicit and explicit claims of customers, as well as their perception of how well a firm is able to honor current and future claims. We argue that the concept of customer satisfaction represents a suitable proxy for the commitment to customer claims. Customer satisfaction reflects both the expectations that customers have about the products and services that a firm sells, and their perception of how well the firm is able to meet these expectations. The concept of customer satisfaction is not restricted to perceptions of how well the firm fulfills the explicit claims of customers (e.g., warranties), but also captures the firm's commitment to their implicit claims (e.g., quality, reliability).

\subsection{Hypotheses}

We derive a number of testable hypotheses from the preceding discussion. Our primary hypothesis is that firms that are committed to honoring customer claims pursue a more conservative capital structure policy.

\section{Hypothesis 1: Customer satisfaction is negatively related to firm leverage.}

Prior research shows that firms do not frequently rebalance their capital structure to an optimal level (Baker and Wurgler, 2002; Welsh, 2004). As a result, the observed leverage ratios can deviate from their target range because of extraneous factors, which may affect the conclusions drawn from our leverage analysis. To further investigate whether commitment to customer claims influences the capital structure decisions of firms, we also study their actual financing decisions. Firms can alter their capital structure by issuing and repurchasing debt or equity. We expect that firms that target a conservative debt ratio are more likely to issue equity when in need of external financing, and more likely to repurchase debt in case of financial surplus. Therefore, the following hypotheses are tested:

\footnotetext{
Hypothesis 2: Customer satisfaction is negatively (positively) related to the probability of issuing debt (equity).
}
Hypothesis 3: Customer satisfaction is positively (negatively) related to the probability of repurchasing debt (equity).

\subsection{Data}

We rely on the American Customer Satisfaction Index (ACSI) as a proxy for the firm's commitment to customer claims. The ACSI was developed by the National Quality Research Center at the University of Michigan's Stephen M. Ross School of Business to measure the quality of goods and services as experienced by the customers that consume them (Fornell, 
Johnson, Anderson, Cha, and Bryant, 1996). ACSI captures the level of quality and reliability that the customer expects, the post-purchase evaluation of the products and services, and the overall level of satisfaction as well as satisfaction relative to expectations. Moreover, it addresses repurchase likelihood and price tolerance in case of repurchase, which essentially constitutes customer's willingness to commit to the firm's product and services in the future. The fact that the ACSI reflects actual customer experiences and is calibrated to maximize customers' loyalty and repurchase intention is a valuable feature of the measure for the purpose of testing the stakeholder theory of capital structure.

The customer satisfaction levels are estimated on the basis of periodic telephone and internet surveys, in which consumers respond to questions regarding their expectations, the perceived quality, and the perceived value of a firm's products or services. The index contains customer satisfaction scores for more than 200 firms with significant U.S. market shares, which are recorded as of 1994 and updated on an annual basis. Each of the scores ranges on a scale from 0 to 100 , where a higher number represents a higher level of customer satisfaction. ${ }^{40}$

Our data on ACSI cover the period 1995-2008. After excluding multi-brand and nondomestic firms from our sample, we match these data with firm characteristics from Compustat. The set of characteristics comprises information on firms' book leverage, market leverage, decision to issue/repurchase debt or equity, total assets, tangibility, profitability, market-to-book ratio, dividend paying behavior, asset growth, reporting of R\&D expenses, slack, depreciation, deviation from industry leverage, proportion of debt that is due in the next 3 years, and stock return. All continuous variables are winsorized at the 1st and 99th percentile to control for the influence of outliers.

In addition to these firm characteristics, we collect data on the creditworthiness of firms in the form of long-term domestic issuer ratings issued by Standard \& Poor's (S\&P). The S\&P credit rating classifications are recoded into numerical values using two different approaches that have been suggested in the credit risk literature. The first approach allocates credit ratings into categories ranging from 1-7 to ensure sufficient coverage in each of the specified categories (e.g., Ashbaugh-Skaife, Collins, and Lafond, 2006); while the second applies a grading from 1-22 to capture subtle differences between rating classes (e.g., Anderson, Mansi, and Reeb, 2004). A higher value on either of the rating variables reflects a better credit standing and therefore lower default risk.

After the data matching process, we are left with a sample of at most 1,301 yearly observations from 179 firms. Table 5.1 reports summary statistics and provides details on the composition of all variables.

\footnotetext{
${ }^{40}$ Since its introduction, the ACSI has found widespread application in marketing research (e.g., Mittal and Kamakura, 2001; Singh and Sirdeshmukh, 2000; Reinartz, Kraft, and Hoyer, 2004; Mithas, Krisnan, and Fornell, 2005), and in a more recent body of literature that establishes a link between market-based assets and key measures of financial performance (e.g., Ittner et al., 1998; Anderson, Fornell, and Mazvancheryl, 2004; Fornell, Mithas, Morgeson, and Krishnan, 2006; Gruca and Rego, 2005; Morgan and Rego, 2006; Jacobson and Mizik, 2009a, 2009b; Anderson and Mansi, 2009).
} 


\section{TABLE 5.1}

\section{Descriptive statistics}

This table reports sample characteristics. The sample period is 1995-2008. Customer satisfaction is the American Customer Satisfaction Index (ACSI) score lagged by one year. Book leverage is (data9 + data34) / data6, and Market leverage is (data9 + data34) / (data9 + data34 + data24 $x$ data25). Issuance equals one for a debt issue, and equals zero for an equity issue. Repurchase equals one for a debt repurchase, and equals zero for an equity repurchase. Issuance equals one for a debt issuance, and equals zero for an equity issuance. Total assets is defined as data6, and reported in millions of dollars. Tangibility is data 8 / data6, and Profitability is data13 / data6. The market-to-book ratio is calculated as (data9 + data34 + data10 + data24 $\times$ data25) / data6. MTB dummy is one when the market-to-book ratio exceeds one, and is zero otherwise. Dividend paying is a dummy variable that equals one if data 21 exceeds zero, and is zero otherwise. Asset growth is (data6 / lagged data6) minus one. R\&D dummy is one if data 46 exceeds 0 , and zero otherwise. Slack is data1 divided by data6, and Depreciation is data14 / data6. Deviation from industry leverage is a firm's book leverage minus the average book leverage ratio in an industry based on the 4-digit SIC-code. The fraction of debt that is due in three years is computed as (data44 + data91 + data92) / (data9 + data34). The stock return is computed by dividing the stock price in a given year (data24) by the stock price two years before. Rating (1-22) and Rating (1-7) are S\&P long-term credit ratings that are classified on a 7-point (CCC\&D-AAA) and 22-point (D-AAA) scale, respectively, and where '1' denotes the lowest rating category.

\begin{tabular}{|c|c|c|c|c|c|c|}
\hline Variable & \# Obs. & Mean & Std. Dev. & Median & Min. & Max. \\
\hline \multicolumn{7}{|l|}{ Test Variable } \\
\hline Customer satisfaction (t-1) & 1,301 & 75.75 & 6.42 & 76 & 49 & 90 \\
\hline \multicolumn{7}{|l|}{ Dependent Variable } \\
\hline Book leverage & 1,301 & 0.31 & 0.16 & 0.32 & 0 & 0.88 \\
\hline Market leverage & 1,301 & 0.32 & 0.22 & 0.28 & 0 & 0.93 \\
\hline Issuance & 546 & 0.92 & 0.27 & 1 & 0 & 1 \\
\hline Repurchase & 725 & 0.53 & 0.50 & 1 & 0 & 1 \\
\hline \multicolumn{7}{|l|}{ Control Variables } \\
\hline Total assets & 1,301 & 44,043 & 110,046 & 14,666 & 172 & 715,348 \\
\hline Tangibility & 1,301 & 0.39 & 0.22 & 0.39 & 0.01 & 0.86 \\
\hline Profitability & 1,301 & 0.14 & 0.08 & 0.13 & -0.12 & 0.38 \\
\hline Market-to-book ratio & 1,301 & 1.52 & 1.29 & 1.06 & 0.13 & 9.06 \\
\hline MTB dummy & 1,301 & 0.54 & 0.50 & 1 & 0 & 1 \\
\hline Dividend paying & 1,301 & 0.78 & 0.41 & 1 & 0 & 1 \\
\hline Asset growth & 1,301 & 0.09 & 0.28 & 0.05 & -0.31 & 2.59 \\
\hline R\&D dummy & 1,301 & 0.26 & 0.44 & 0 & 0 & 1 \\
\hline Slack & 1,301 & 0.08 & 0.12 & 0.04 & 0.00 & 0.66 \\
\hline Depreciation & 1,301 & 0.04 & 0.02 & 0.04 & 0.00 & 0.13 \\
\hline Deviation from industry & 1,289 & 0.03 & 0.14 & 0.02 & -0.31 & 0.55 \\
\hline Debt due in three years & 1,046 & 0.25 & 0.19 & 0.40 & 0 & 1 \\
\hline Stock return & 1,274 & 1.11 & 0.62 & 1.05 & 0.12 & 4.86 \\
\hline Rating (1-7) & 1,163 & 4.32 & 1.13 & 4 & 1 & 7 \\
\hline Rating (1-22) & 1,163 & 15.01 & 3.43 & 15 & 1 & 22 \\
\hline
\end{tabular}




\subsection{Empirical Analysis}

\subsubsection{Univariate tests}

For a first insight into the link between customer claims and firms' capital structure decisions, we conduct univariate tests on the primary variables of our empirical analysis. Within each calendar year, we rank firms into quintiles based on their relative customer satisfaction performance within the ACSI universe. We then estimate the mean values of each variable within a given quintile, and compare these estimates for firms in the top and bottom quintiles. Table 5.2 reports on the variable means as well as t-statistics for the difference in means between the top and bottom performers.

The univariate results are in line with our primary hypothesis that customer-oriented firms hold less debt in their capital structure to certify commitment to the customer claims that they sell. Firms with high ACSI levels (top quintile) have significantly lower book as well as market leverage ratios than firms with low ACSI levels (bottom quintile), before controlling for the effect of other capital structure determinants. However, the analysis also suggests that firms with high customer satisfaction levels have significantly higher credit ratings than their counterparts. The latter result implies that firms with higher customer satisfaction have a lower default risk and should therefore have a higher debt capacity. Altogether, the univariate analysis highlights the need to control for differences in firm characteristics between firms with high and low customer satisfaction scores.

TABLE 5.2

\section{Univariate analysis}

This table reports univariate tests of the relation between our proxy for the firm's commitment to customer claims (ACSI) and the central variables in our analysis. ACSI is the American Customer Satisfaction Index. Within each calendar year, we rank firms into quintiles based on their relative customer satisfaction performance within the ACSI universe. Columns 2 and 3 report the means of the firm characteristics for firms in the top and bottom quintiles. Column 4 reports $t$-statistics for the difference in means between firms in the top quintile and bottom quintile.

\begin{tabular}{llll}
\hline \hline Variable & $\begin{array}{c}\text { ACSI } \\
\text { Bottom quintile }\end{array}$ & Top quintile & $\begin{array}{l}\text { Difference in } \\
\text { means (t-stats) }\end{array}$ \\
\hline Book leverage & 0.35 & 0.31 & $-2.54^{* *}$ \\
Market leverage & 0.46 & 0.20 & $-14.89^{* * *}$ \\
Rating (1-7) & 3.86 & 4.71 & $8.60^{* * *}$ \\
Rating (1-22) & 13.38 & 16.22 & $8.69^{* * *}$ \\
Log(assets) & 10.00 & 9.23 & $-6.68^{* * *}$ \\
Tangibility & 0.43 & 0.30 & $-7.32^{* * *}$ \\
Profitability & 0.11 & 0.18 & $10.26^{* * *}$ \\
Market-to-book ratio & 0.99 & 2.33 & $12.09^{* * *}$ \\
Dividend paying & 0.64 & 0.85 & $5.85^{* * *}$ \\
Asset growths & 0.08 & 0.10 & 0.56 \\
R\&D dummy & 0.08 & 0.66 & $18.01^{* * *}$ \\
Slack & 0.10 & 0.09 & 0.47 \\
Depreciation & 0.44 & 0.45 & 0.76 \\
\hline
\end{tabular}

$* \mathrm{p} \leq 0.1, * * \mathrm{p} \leq 0.05, * * * \mathrm{p} \leq 0.01$ 
An inspection of the correlation statistics confirms the preceding findings. Moreover, it shows that our multivariate analysis does not suffer from multicollinearity problems, which we also corroborate in variance inflation factor (VIF) tests. The correlation statistics and VIF tests for the primary regression variables are presented in Tables 5.1A and 5.2A of the appendix, respectively.

\subsubsection{Customer satisfaction and credit risk}

The first stage of our multivariate analysis examines whether firms with higher customer satisfaction have better credit ratings. While we utilize ACSI as an instrument to identify a firm's commitment to customer claims, it is important to recognize that customer satisfaction in itself may affect the leverage ratio by reducing credit risk. Prior research suggests that customer satisfaction improves cash flows, which in turn allows firms to achieve a better credit standing, lower cost of debt, and therefore higher debt capacity. ${ }^{41}$ As a result, firms with higher customer satisfaction should be able to increase their leverage ratio in order to seize additional tax benefits. Given that such a relation implies a positive relation between ACSI and leverage, the negative relation that we have estimated so far could be biased upwards. We consequently estimate a pooled ordered logit model of the form:

$$
\text { Credit Rating }_{i, t}=\alpha+\beta \text { ACSI }_{i, t-1}+\sum_{k=1}^{K} \gamma_{k} \text { Control }_{k, i, t}+\varepsilon_{i, t}
$$

where Credit Rating refers to either of our two credit rating measures, and ACSI is the firm's customer satisfaction score lagged by one year. Control is defined as a set of control variables that comprises the logarithm of sales, tangibility, profitability, market-to-book ratio, dividend paying, book leverage, and working capital. To account for the hypothesized relation between the firm's commitment to customer claims and its debt leverage, we impose an orthogonality condition between book leverage and the customer satisfaction measure. ${ }^{42}$ Throughout the analysis, we control for year as well as industry fixed effects in our regressions, and estimate robust standard errors that are clustered at the firm level (Petersen, 2009). Table 5.3 presents the output of the credit risk analysis.

The regression results show that credit ratings indeed improve for firms with higher customer satisfaction levels. We find a positive and statistically significant customer satisfaction coefficient for both model specifications. The control variables carry their expected

\footnotetext{
${ }^{41}$ Earlier research indeed finds that customer satisfaction has a measurable impact on purchase intentions (Bolton and Drew, 1991), customer retention (Mittal and Kamakura, 2001), reduced customer defections (Anderson, 1994), share of wallet (Keiningham, Aksoy, and Hsu, 2007; Keiningham, Perkins-Munn, and Evans, 2003), increased receptiveness to cross-selling efforts (Fornell, 1992), reduced complaints (Bolton, 1998; Fornell, 1992), and word of mouth (Anderson, 1998). Other evidence supports the idea that strong customer satisfaction reduces the firm's cash flow volatility (Gruca and Rego, 2005), positively influences productivity (Anderson, Fornell, and Rust, 1997), profit margins (Ittner and Larcker, 1998; Ittner, Larcker, and Taylor, 2009), return on assets (ROA) and return on invested capital (ROI) (e.g., Anderson, Fornell, and Lehmann, 1994; Anderson et al., 1997; Ittner et al., 2009). Finally, Anderson and Mansi (2009) find that higher customer satisfaction is related to higher credit ratings and a lower cost of debt.

${ }^{42}$ The results are very similar without this orthogonality condition.
} 


\section{TABLE 5.3}

\section{The effect of customer satisfaction on credit ratings}

This table reports the relation between customer satisfaction (ACSI) and S\&P long-term credit ratings. The credit ratings are either based on a 7-point scale as in Ashbaugh-Skaife et al. (2006), or a 22-point scale as in Anderson et al. (2004). The results of the credit rating analysis are based on the estimation of an ordered logit model. We also show corresponding results of a binary model, in which one indicates an investment grade rating (i.e., a credit rating equal or higher than $\mathrm{BBB}^{-}$), and zero indicates speculative grade ratings. Book leverage* is orthogonalized against the customer satisfaction measure to account for our hypothesized relation between these two variables. Working capital is defined as (data4 - data5) / data6. Marginal effects are based on a one unit change in the explanatory variable holding all other explanatory variables at their sample means. Dummy variables are set to zero. Their marginal effects are calculated by evaluating the fitted value assuming the dummy variable under consideration equals one. Industries are based on the Fama-French 12 industry classification. T-statistics are based on panel-robust standard errors. Robust t-statistics appear in parentheses and are based on standard errors that are clustered at the firm level, as suggested by Petersen (2009).

\begin{tabular}{|c|c|c|c|c|}
\hline & \multicolumn{2}{|c|}{ Credit ratings } & \multicolumn{2}{|c|}{ Investment grade } \\
\hline & $(1-7)$ & $(1-22)$ & Coefficient & Marginal effect \\
\hline $\operatorname{ACSI}(t-1)$ & $\begin{array}{c}0.053 * * * \\
(2.66)\end{array}$ & $\begin{array}{c}0.052 * * * \\
(2.72)\end{array}$ & $\begin{array}{c}0.141 * * \\
(2.45)\end{array}$ & 0.005 \\
\hline Log(Sales) & $\begin{array}{c}0.701 * * * \\
(7.27)\end{array}$ & $\begin{array}{c}0.654 * * * \\
(7.62)\end{array}$ & $\begin{array}{c}1.752 * * * \\
(4.75)\end{array}$ & 0.058 \\
\hline Tangibility & $\begin{array}{c}0.996 \\
(1.41)\end{array}$ & $\begin{array}{l}1.074 \\
(1.62)\end{array}$ & $\begin{array}{c}4.936 * * * \\
(2.92)\end{array}$ & 0.163 \\
\hline Profitability & $\begin{array}{c}5.883 * * * \\
(3.84)\end{array}$ & $\begin{array}{c}5.646^{* * * *} \\
(4.02)\end{array}$ & $\begin{array}{c}20.774 * * * \\
(4.62)\end{array}$ & 0.688 \\
\hline Market-to-book ratio & $\begin{array}{c}0.224^{*} \\
(1.91)\end{array}$ & $\begin{array}{c}0.258^{* *} \\
(2.31)\end{array}$ & $\begin{array}{c}0.657^{* *} \\
(2.27)\end{array}$ & 0.022 \\
\hline Dividend paying & $\begin{array}{c}1.712^{* * * *} \\
(8.38)\end{array}$ & $\begin{array}{c}1.701 * * * \\
(8.81)\end{array}$ & $\begin{array}{c}3.212 * * * \\
(5.45)\end{array}$ & 0.295 \\
\hline Book leverage* & $\begin{array}{c}-2.407 * * * \\
(-4.08)\end{array}$ & $\begin{array}{c}-2.729 * * * \\
(-5.04)\end{array}$ & $\begin{array}{c}-6.342 * * * \\
(-3.72)\end{array}$ & -0.210 \\
\hline Working capital & $\begin{array}{c}-3.880^{\text {**** }} \\
(-3.11)\end{array}$ & $\begin{array}{c}-3.839 * * * \\
(-3.24)\end{array}$ & $\begin{array}{l}-3.754 \\
(-1.40)\end{array}$ & -0.124 \\
\hline Industry Fixed Effects & Yes & Yes & Yes & \\
\hline Year Fixed Effects & Yes & Yes & Yes & \\
\hline Pseudo $\mathrm{R}^{2}$ & 0.37 & 0.24 & 0.62 & \\
\hline \# Observations & 1,163 & 1,163 & 1,073 & \\
\hline
\end{tabular}

$* \mathrm{p} \leq 0.1, * * \mathrm{p} \leq 0.05, * * * \mathrm{p} \leq 0.01$

signs and are generally significant (see, e.g., Altman and Rijken, 2004, Verwijmeren and Derwall, 2010). Table 5.3 also shows that this credit risk relation is economically meaningful. We estimate a binary logit model for a straightforward interpretation of the marginal effects. The dependent variable in this model is equal to one for firms with investment grade debt (BBB ratings or better), and zero for firms with speculative grade debt. We find that the marginal effect of customer satisfaction on the investment grade debt dummy is stronger than for most of 
the other explanatory variables. ${ }^{43}$ These results suggest that firms with higher customer satisfaction have a higher debt capacity than their counterparts, and that without controlling for this effect, inferences regarding the relation between commitment to customer claims and capital structure decisions can be biased.

\subsubsection{Customer claims and leverage}

For our test of the relation between customer-based strategies and capital structure decisions, we rely on pooled ordinary least squares regressions. The general model specification is of the form:

$$
\text { Firm Leverage }_{i, t}=\alpha+\beta \text { ACSI }_{i, t-n}+\sum_{j=1}^{J} \gamma_{j} \text { Control }_{j, i, t-n}+\varepsilon_{i, t}
$$

where the dependent variable is either defined as the firm's book leverage or market leverage, and the explanatory variable of interest is the firm's ACSI score lagged by one year. The set of control variables includes firm size (logarithm of total assets), tangibility, profitability, market-to-book ratio, dividend paying behavior, asset growth, R\&D expenses, slack, depreciation, and credit ratings.

We consecutively estimate four model specifications for the relation between the commitment to customer claims and firm leverage. Model 1 involves regressing leverage on the ACSI, while controlling for industry membership and year fixed effects. Model 2 extends the basic specification in line with Frank and Goyal (2009), who show that the most reliable and consistent firm characteristics with an effect on leverage over the period 1950-2003 are firm size, tangibility, profitability, the market-to-book ratio, and whether the firm pays dividends. Model 3 includes additional control variables in the form of asset growth, R\&D expenses, slack, and depreciation (Verwijmeren and Derwall, 2010). Model 4 adds credit ratings as a control variable to account for the influence of a firm's credit standing on its capital structure decisions (e.g., Kisgen, 2006 and 2009). Given the previously documented relation between credit ratings and customer satisfaction as well as their significant correlation with some of the other firm characteristics, we orthogonalize the credit rating variable against the set of explanatory variables. ${ }^{44}$ Table 5.4 summarizes the regression results for the relation between firms' commitment to customer claims and book leverage.

We find that higher ACSI scores are associated with lower book leverage, which is in line with our primary hypothesis. The effect is consistently negative and statistically significant at the $1 \%$ level in all model specifications. Each extra point on the ACSI score lowers the book debt ratio by an absolute $0.6 \%$, ceteris paribus. Whereas the adjusted R-squared of the regression models $(0.36-0.49)$ is comparable to that of earlier studies, the control variables are

\footnotetext{
43 The marginal effects are based on a one unit change in the explanatory variable, while holding all other explanatory variables fixed at their sample means. Note that customer satisfaction is an integer variable, while most of the firm characteristics are defined as fractional variables.

${ }^{44}$ Our results remain very similar, when we use the unmodified credit ratings.
} 


\section{TABLE 5.4}

\section{Customer claims and book leverage}

This table summarizes the relation between firms' commitment to customer claims (ACSI) and their debt leverage, using book leverage as proxy. We estimate a pooled ordinary least squares regression with industry and year fixed effects. Industries are based on the Fama-French 30 industry classification. Model 2 reports the results when we use the control variables suggested by Frank and Goyal (2009). Model 3 includes additional control variables based on Verwijmeren and Derwall (2010). Model 4 adds long-term credit ratings that are based on a scale from 1 (D) to 22 (AAA), and orthogonalized against customer satisfaction as well as the other explanatory variables. Robust t-statistics appear in parentheses and are based on standard errors that are clustered at the firm level, as suggested by Petersen (2009).

Book Leverage
(1)
(2)
(3)
(4)

ACSI (t-1)

$-0.007 * * *$

$(-3.07)$

$\log$ (Assets)

Tangibility

Profitability

Market-to-book ratio

Dividend paying

Asset growth

R\&D dummy

Slack

Depreciation

Rating*

Industry fixed effects

Year fixed effects

Adj. $\mathrm{R}^{2}$

\# Observations

$-0.006^{* * * *}$

$(-3.25)$

\subsection{5}

$(0.48)$

0.010

$(0.13)$

0.000

$(0.00)$

0.006

$(0.51)$

$-0.060 * *$

$(-2.39)$

${ }^{*} \mathrm{p} \leq 0.1,{ }^{* *} \mathrm{p} \leq 0.05, * * * \mathrm{p} \leq 0.01$

$\begin{array}{lc}0.006 * * * & -0.006 * * * \\ (-3.41) & (-4.27)\end{array}$

$-0.001$

$-0.013$

$(-1.41)$

0.029

(0.44)

$-0.005$

$-0.462 * *$

$-0.042$

$(-2.41)$

$(-0.21)$

$0.030^{* *}$

(1.02)

(2.39)

$-0.063 * *$

$(-2.54)$

$-0.074 * * *$

$(-3.34)$

$-0.003$

0.002

$(-0.20)$

$(0.12)$

0.003

0.010

(0.09)

(0.39)

$-0.209$

$-0.179$

$(-1.54)$

$(-1.57)$

$-0.237$

0.646

$(-0.37)$

(1.06)

$-0.023^{* * *}$

(-6.66)

$\begin{array}{cccc}\text { Yes } & \text { Yes } & \text { Yes } & \text { Yes } \\ \text { Yes } & \text { Yes } & \text { Yes } & \text { Yes } \\ & & & \\ .36 & 0.38 & 0.39 & 0.49 \\ 301 & 1,301 & 1,301 & 1,186\end{array}$

Yes

Yes

186 
generally insignificant. We only observe statistically significant relations for several of the controls, after extending the model with credit ratings. The most persistent of these effects is the firm's dividend paying behavior, which is negatively related to leverage as suggested by Fama and French (2002). Dividend-paying firms are generally less constrained in their finances than non-dividend paying firms, and according to the pecking order theory unconstrained firms are less dependent on debt. We also find a significantly negative relation for profitability and credit ratings, which is in line with the preceding argumentation and commonly observed in earlier studies (e.g., Rajan and Zingales, 1995; De Jong, Kabir, and Nguyen, 2008). However, the coefficient on the market-to-book ratio is positive, which runs counter to expectations. To test the robustness of these findings, we repeat our regression analysis with market leverage as alternative dependent variable. The results are presented in Table 5.5.

We again observe a significantly negative relation between the ACSI and market leverage. Each extra point on the ACSI score lowers the market debt ratio by an absolute $1 \%$, ceteris paribus. The adjusted R-squared of the models $(0.45-0.72)$ exceeds that of the book leverage analysis. Furthermore, the control variables are generally significant and carry their expected signs. In particular, the coefficient on the market-to-book ratio has its expected negative loading. We find a positive relation for firm size, which corresponds with the idea that larger firms have more diversified operations and are thus expected to have higher debt ratios. The R\&D dummy and the slack variable are both negatively related to leverage. Firms with R\&D activities are expected to have more intangible assets and unique products, which requires them to hold less debt in their capital structure (Kale and Shahrur, 2007). Firms with more slack, according to the pecking order theory, are less dependent on external financing and thus require less debt.

Our analysis up to this point comprises all firms with available ACSI information, which includes financial firms and utilities. Considering that the latter are expected to have significantly different capital structures from that of other businesses (e.g., Berger, Ofek, and Yermack, 1997), we control for possible biases by repeating the analysis without these firms. ${ }^{45}$ The results are summarized in Table 5.6.

When we exclude financial firms and utilities from our sample, the negative relation between our proxy for the commitment to customer claims and firm leverage grows stronger. This finding coincides with Cornell and Shapiro's (1987) prediction that regulated firms commit fewer resources to certify themselves, because their stakeholder claims are implicitly guaranteed by the government. Most notably, the book leverage regression shows a considerable improvement in model fit, and its explanatory variables are now generally significant and carry their predicted signs. The latter finding underscores that the selected model specifications are less suitable for explaining the book leverage of regulated firms.

In summary, the leverage analysis consistently confirms the prediction of our primary hypothesis: Firms that are committed to customer claims hold less debt in their capital structure. The documented relation corresponds with a certification strategy that aims at optimizing the return on customer claims, by signaling a credible commitment and ability to honor these claims. Moreover, this relation appears to hold despite the higher debt capacity of these firms that is implied by the positive relation between customer satisfaction and credit ratings.

\footnotetext{
${ }^{45}$ We exclude 18 financial firms (SIC codes 6000-6999) and 31 utilities (SIC codes 4900-4999).
} 


\section{TABLE 5.5}

\section{Customer claims and market leverage}

This table summarizes the relation between firms' commitment to customer claims (ACSI) and their debt leverage, using market leverage as proxy. We estimate a pooled ordinary least squares regression with industry and year fixed effects. Industries are based on the Fama-French 30 industry classification. Model 2 reports the results when we use the control variables suggested by Frank and Goyal (2009). Model 3 includes additional control variables based on Verwijmeren and Derwall (2010). Model 4 adds long-term credit ratings that are based on a scale from 1 (D) to 22 (AAA), and orthogonalized against customer satisfaction as well as the other explanatory variables. Robust t-statistics appear in parentheses and are based on standard errors that are clustered at the firm level, as suggested by Petersen (2009).

\section{Market Leverage}
(1)
(2)
(3)
(4)

$\operatorname{ACSI}(\mathrm{t}-1)$

$\log$ (Assets)

Tangibility

Profitability

Market-to-book ratio

Dividend paying

Asset growth

R\&D dummy

Slack

Depreciation

Rating*

\section{Industry fixed effects}

Year fixed effects

Adj. $\mathrm{R}^{2}$

\# Observations

$$
-0.015 * * *
$$

$(-5.37)$

$\mathrm{p} \leq 0.1, * * \mathrm{p} \leq 0.05, * * * \mathrm{p} \leq 0.01$

\section{$(-5.37)$}

$-0.010 * * *$
$(-4.40)$

$0.031 * *$
$(2.44)$
-0.027
$(-0.28)$
$-0.796 * * *$
$(-3.78)$
$-0.030 * * *$
$(-3.22)$
$-0.094 * * *$
$(-3.13)$

Yes

Yes

0.45

1,301

$-0.010^{* * * *}$
$(-4.61)$

$0.025^{*}$

(1.89)

$-0.081$

$(-0.81)$

$-0.903 * * *$

$(-4.16)$

-0.017 *

$(-1.71)$

$-0.099 * * *$

(-3.39)

0.003

(0.13)

$-0.043$

$(-1.49)$

$-0.332 * * *$

$(-2.86)$

0.246

(0.35)

Yes

Yes

0.59

1,301
$-0.010^{* * *}$

$(-5.67)$

0.012

(0.95)

$-0.030$

$(-0.49)$

$-1.534 * * *$

$(-9.86)$

$-0.007$

$(-1.07)$

$-0.106^{* * *}$

$(-4.62)$

$-0.026^{*}$

(-1.66)

$-0.038 *$

$(-1.70)$

$-0.419 * * *$

$(-3.88)$

$1.287 * *$

(2.26)

$-0.035^{* * *}$

(-12.05)

Yes

Yes

0.72 


\section{TABLE 5.6}

\section{Customer claims and firm leverage (excluding banks and utilities)}

This table summarizes the relation between firms' commitment to customer claims (ACSI) and their debt leverage after excluding banks (SIC 6000-6999) and utilities (SIC 4900-4949) from our sample. We estimate pooled ordinary least squares regressions with industry and year fixed effects. Industries are based on the Fama-French 30 industry classification. Rating* is the S\&P long-term credit rating (1-22), which we orthogonalize against the customer satisfaction measure as well as other explanatory variables. Robust t-statistics appear in parentheses and are based on standard errors that are clustered at the firm level, as suggested by Petersen (2009, RFS).

\section{Book Leverage Market Leverage}
(1)
(4)
(1)
(4)

\begin{tabular}{|c|c|c|c|c|}
\hline ACSI (t-1) & $\begin{array}{c}-0.009 * * * \\
(-3.42)\end{array}$ & $\begin{array}{c}-0.010 * * * \\
(-4.43)\end{array}$ & $\begin{array}{c}-0.019 * * * \\
(-5.80)\end{array}$ & $\begin{array}{c}-0.012 * * * * \\
(-6.03)\end{array}$ \\
\hline Log(Assets) & & $\begin{array}{l}0.015 \\
(1.30)\end{array}$ & & $\begin{array}{l}-0.013 \\
(-1.25)\end{array}$ \\
\hline Tangibility & & $\begin{array}{l}-0.077 \\
(-0.93)\end{array}$ & & $\begin{array}{l}-0.017 \\
(-0.19)\end{array}$ \\
\hline Profitability & & $\begin{array}{c}-1.199 * * * \\
(-6.14)\end{array}$ & & $\begin{array}{c}-1.244 * * * \\
(-7.65)\end{array}$ \\
\hline Market-to-book ratio & & $\begin{array}{c}-0.021 * * \\
(-2.32)\end{array}$ & & $\begin{array}{c}-0.013^{*} \\
(-1.81)\end{array}$ \\
\hline Dividend paying & & $\begin{array}{c}-0.119 * * * \\
(-4.55)\end{array}$ & & $\begin{array}{c}-0.099 * * * \\
(-3.77)\end{array}$ \\
\hline Asset growth & & $\begin{array}{c}-0.047 * * * \\
(-2.84)\end{array}$ & & $\begin{array}{c}-0.039 * * * \\
(-2.26)\end{array}$ \\
\hline R\&D dummy & & $\begin{array}{l}-0.002 \\
(-0.07)\end{array}$ & & $\begin{array}{c}-0.041 * * \\
(-2.05)\end{array}$ \\
\hline Slack & & $\begin{array}{c}-0.404 * * * \\
(-3.92)\end{array}$ & & $\begin{array}{c}-0.374 * * * \\
(-4.05)\end{array}$ \\
\hline Depreciation & & $\begin{array}{l}1.156^{*} \\
(1.83)\end{array}$ & & $\begin{array}{l}0.720 \\
(1.20)\end{array}$ \\
\hline Rating* & & $\begin{array}{c}-0.034 * * * \\
(-8.00)\end{array}$ & & $\begin{array}{c}-0.035 * * * * \\
(-9.89)\end{array}$ \\
\hline Industry fixed effects & Yes & Yes & Yes & Yes \\
\hline Year fixed effects & Yes & Yes & Yes & Yes \\
\hline Adj. $R^{2}$ & 0.34 & 0.68 & 0.43 & 0.74 \\
\hline \# Observations & 914 & 833 & 914 & 833 \\
\hline
\end{tabular}

${ }^{*} \mathrm{p} \leq 0.1,{ }^{* *} \mathrm{p} \leq 0.05, * * * \mathrm{p} \leq 0.01$ 


\subsubsection{Issue and repurchase decisions}

The firm's book leverage reflects the aggregate of its past capital structure decisions. Since firms do not frequently rebalance their capital structure to an optimal level (Baker and Wurgler, 2002; Welsh 2004), it can be influenced by many extraneous factors. For example, firms with strong past performance tend to have lower leverage ratios, because retained earnings increase their equity level. Given that the results of our book leverage analysis may be affected by such deviations, we examine whether customer claims are also associated with the firm's issue and repurchase decisions at the time of capital structure changes. Analyzing debt-equity decisions allows us to more effectively isolate the influence of a factor on the target leverage from its correlation with temporary deviations in the leverage ratio (Mackie-Mason, 1990; Hovakimian, Opler, and Titman, 2001; Lipson and Mortal, 2009). If the commitment to customer claims is a relevant factor as suggested by the preceding tests, we expect a negative relation the ACSI and the decision to issue debt instead of equity. In contrast, we expect that the ACSI has a positive relation with the decision to repurchase debt instead of equity.

We define a firm as issuing (repurchasing) a security when the net amount issued (repurchased) divided by the book value of assets at the beginning of the fiscal year exceeds 1\%. Following Hovakimian et al. (2001) and Hovakimian, Hovakimian, and Tehranian (2004), we calculate net equity issued as the proceeds from the sale of common and preferred stock minus the amount of common and preferred stock repurchased as well as the change in the value of preferred stock (data108 - data115 - data10). Net debt issued is calculated as the change in the book value of total debt (data9 + data34). Cases where both debt and equity were issued (repurchased) within a fiscal year are omitted. ${ }^{46}$

We estimate a binary logit model, in which the dependent variable equals one for a debt issue (repurchase), and equals zero for an equity issue (repurchase). The control variables are based on Rajan and Zingales (1995), Hovakimian et al. (2001), and Lipson and Mortal (2009). Table 5.7 shows the regression results.

For the issue decisions, we find that firms with high ACSI scores are less likely to issue debt when they require external financing. The effect is negative and statistically significant at the $10 \%$ level. The results for the control variables show that profitable firms are more likely to issue debt instead of equity. In contrast, firms with a market-to-book ratio in excess of one, leverage ratios that are higher than that of their industry peers, or higher stock returns are more likely to issue equity. However, the significance of the issue decision variable needs to be interpreted with caution, since the marginal effect of a unit change is close to zero. A possible explanation for this weak effect is the limited variation in the issue decisions variable, given that only $8 \%$ of the available observations are equity issues.

Our test of the repurchase decisions shows that firms with high ACSI scores are more likely to repurchase debt than firms with low ACSI scores, ceteris paribus. The effect is positive and statistically significant at the 5\% level. The coefficients of the control variables generally correspond with the findings of prior studies (e.g., Verwijmeren and Derwall, 2010). Taken as a whole, our results on issue and repurchase decisions provides reinforce the robustness of the hypothesis that firms with a high commitment to customer claims have a lower target leverage ratio. The outcomes also suggest that this lower leverage is the result of both a higher likelihood of equity issues in case of financing needs, and particularly a higher likelihood of debt repurchases in case of financing surpluses.

\footnotetext{
${ }^{46}$ For a discussion of dual issues and their relation to capital structure theory see Hovakimian et al. (2001).
} 


\section{TABLE 5.7}

\section{Customer claims and issue and repurchase decisions}

This table reports the results of a binary logit model that estimates firms' decision to issue or repurchase securities, and relates this decision to their commitment to customer claims (ACSI). Firms are defined as issuing (repurchasing) a security when the net amount issued (repurchased) divided by the book value of assets at the beginning of the fiscal year exceeds $1 \%$. Cases where firms issue (repurchase) both debt and equity in a fiscal year are omitted. The dependent variable equals one for a debt issue (repurchase), and equals zero for an equity issue (repurchase). The control variables are based on Rajan and Zingales (1995) and Hovakimian et al. (2001). Marginal effects are based on a one unit change in the explanatory variable holding all other explanatory variables at their sample means. Dummy variables are set to zero. Their marginal effects are calculated by evaluating the fitted value assuming the dummy variable under consideration equals one. Robust $t$-statistics appear in parentheses and are based on standard errors that are clustered at the firm level, as suggested by Petersen (2009, RFS).

\begin{tabular}{|c|c|c|c|c|}
\hline & \multicolumn{2}{|c|}{ Issue Decisions } & \multicolumn{2}{|c|}{ Repurchase Decisions } \\
\hline & Coefficient & Marginal effect & Coefficient & Marginal effect \\
\hline ACSI (t-1) & $\begin{array}{l}-0.197 * \\
(-1.73)\end{array}$ & -0.000 & $\begin{array}{c}0.065^{* *} \\
(2.49)\end{array}$ & 0.016 \\
\hline Log(Assets) & $\begin{array}{l}0.633 \\
(0.75)\end{array}$ & 0.000 & $\begin{array}{c}-1.380 * * * \\
(-6.13)\end{array}$ & -0.338 \\
\hline Tangibility & $\begin{array}{l}-1.544 \\
(-0.74)\end{array}$ & -0.001 & $\begin{array}{c}4.395 * * * \\
(3.56)\end{array}$ & 1.075 \\
\hline Profitability & $\begin{array}{c}43.946^{*} \\
(1.88)\end{array}$ & 0.029 & $\begin{array}{c}-14.433 * * * \\
(-4.16)\end{array}$ & -3.530 \\
\hline Market-to-book ratio & $\begin{array}{l}0.018 \\
(0.04)\end{array}$ & 0.000 & $\begin{array}{l}-0.245 \\
(-0.92)\end{array}$ & -0.060 \\
\hline MTB dummy & $\begin{array}{c}-1.931 * * \\
(-2.57)\end{array}$ & -0.001 & $\begin{array}{l}-0.451 \\
(-1.16)\end{array}$ & -0.109 \\
\hline Book leverage & $\begin{array}{l}7.435 \\
(1.21)\end{array}$ & 0.005 & $\begin{array}{l}-0.234 \\
(-0.20)\end{array}$ & -0.057 \\
\hline Dev. from industry leverage & $\begin{array}{c}-5.662 * \\
(-1.86)\end{array}$ & -0.004 & $\begin{array}{l}0.028 \\
(1.02)\end{array}$ & 0.007 \\
\hline Debt due in three years & $\begin{array}{l}0.533 \\
(0.23)\end{array}$ & 0.000 & $\begin{array}{l}0.068 \\
(0.12)\end{array}$ & 0.017 \\
\hline Stock return & $\begin{array}{c}-1.447 * * \\
(-2.10)\end{array}$ & -0.001 & $\begin{array}{c}0.343^{*} \\
(1.75)\end{array}$ & 0.084 \\
\hline Industry fixed effects & Yes & & Yes & \\
\hline Year fixed effects & Yes & & Yes & \\
\hline Pseudo $\mathrm{R}^{2}$ & 0.43 & & 0.32 & \\
\hline \# Observations & 302 & & 565 & \\
\hline
\end{tabular}

$* \mathrm{p} \leq 0.1, * * \mathrm{p} \leq 0.05, * * * \mathrm{p} \leq 0.01$ 


\subsection{Conclusion}

Although customers forms an integral part in the formulation of corporate strategy, only little is known about the interaction between customer claims and financial policy. Using stakeholder theory, this study suggests that the financial policy of firms is affected by the claims that customers purchase as a result of marketing strategies and actions. In particular, we hypothesize that the choice of a conservative capital structure helps the firm to credibly commit to honoring claims purchased by customers. By using customer satisfaction as a proxy for commitment to customer claims, we document evidence consistent with the stakeholder theory of capital structure: firms with a strong commitment to customer claims have lower leverage rates, are more likely to repurchase debt, and less likely to issue debt than their counterparts.

Future research could extend the idea that stakeholder claims generated by marketing actions demand specific financial policies along at least two lines. First, the concept of brand equity has received considerable attention in the explanation of firm performance. From a claims perspective, strong brands can generate substantial explicit and implicit claims among stakeholders, which form a source of reputational damage and loss of firm value, if defaulted on by management. This is especially the case when reputational damage materializes in the form of a "spillover" across a wide range of products and services (see for example Holder, Langrehr, and Hexter 1998). Second, commitment to stakeholder claims may be reflected in financial decisions other than those regarding capital structure. An interesting avenue for future research would be to investigate how customers respond to certain dividend policies. Dividend payments accrue to shareholders and may signal that the firm has less cash to commit to other stakeholders (Cornell and Shapiro 1987; Shapiro 1990, Holder, Langehr, and Hexter 1998). 


\section{A Appendix}

TABLE 5.A1

\section{Collinearity diagnostics}

This table presents the variance inflation factor test for the regression variables of our base model.

\begin{tabular}{lcccc}
\hline \hline & VIF & SQRT(VIF) & Tolerance & $\mathrm{R}^{2}$ \\
\hline ACSI (t-1) & 1.62 & 1.27 & 0.6185 & 0.38 \\
Log(Assets) & 1.39 & 1.18 & 0.7176 & 0.28 \\
Tangibility & 1.70 & 1.31 & 0.5868 & 0.41 \\
Profitability & 2.42 & 1.56 & 0.4131 & 0.59 \\
Market-to-book ratio & 2.52 & 1.59 & 0.3964 & 0.60 \\
Dividend paying & 1.53 & 1.24 & 0.6525 & 0.35 \\
Asset growth & 1.09 & 1.04 & 0.9176 & 0.08 \\
R\&D dummy & 1.50 & 1.23 & 0.6655 & 0.33 \\
Slack & 1.82 & 1.35 & 0.5495 & 0.45 \\
Depreciation & 1.72 & 1.31 & 0.5805 & 0.42 \\
Mean VIF & 1.73 & & & \\
\hline
\end{tabular}

TABLE 5.A2

Correlation statistics

This table reports correlation statistics for the primary test variables. Relations that are significant at the $1 \%$ level are printed in bold.

\begin{tabular}{lllllllllllll} 
A & B & C & D & E & F & G & H & I & J & K & L \\
\hline
\end{tabular}
(A) ACSI (t-1)
(B) Book leverage
$-0.12$
(C) Market leverage
$-0.420 .62$
(D) $\log$ (Assets)
$\begin{array}{lll}-0.19 & \mathbf{0 . 0 0} & \mathbf{0 . 2 8}\end{array}$
(E) Tangibility
$\begin{array}{llll}-0.15 & \mathbf{0 . 2 9} & \mathbf{0 . 1 8} & \mathbf{- 0 . 1 0}\end{array}$
(F) Profitability
$\begin{array}{lllll}0.34 & 0.03 & -0.52 & -0.26 & 0.17\end{array}$
(G) Market-to-book ratio
$\begin{array}{llllll}0.34 & -0.10 & -0.55 & -0.25 & -0.15 & 0.60\end{array}$
(H) Dividend paying
$\begin{array}{llllllll}0.21 & \mathbf{- 0 . 0 3} & \mathbf{- 0 . 0 7} & \mathbf{0 . 2 9} & \mathbf{0 . 1 3} & \mathbf{0 . 1 2} & \mathbf{- 0 . 1 5}\end{array}$
(I) Asset growth
$\begin{array}{llllllll}\mathbf{0 . 0 2} & \mathbf{- 0 . 0 7} & -0.07 & 0.06 & \mathbf{- 0 . 1 2} & -0.01 & \mathbf{0 . 1 8} & -0.07\end{array}$
(J) R\&D dummy
$\begin{array}{lllllllll}0.45 & \mathbf{- 0 . 0 5} & \mathbf{- 0 . 3 2} & \mathbf{- 0 . 0 8} & \mathbf{- 0 . 3 0} & \mathbf{0 . 2 3} & \mathbf{0 . 3 7} & -0.05 & 0.04\end{array}$
(K) Slack
$\begin{array}{lllllllllll}\mathbf{- 0 . 0 6} & \mathbf{- 0 . 3 4} & -0.29 & \mathbf{- 0 . 1 7} & \mathbf{- 0 . 4 2} & \mathbf{- 0 . 1 0} & \mathbf{0 . 3 6} & \mathbf{- 0 . 4 2} & \mathbf{0 . 1 2} & \mathbf{0 . 2 2}\end{array}$
(L) Depreciation
$\begin{array}{lllllllllll}0.00 & \mathbf{0 . 1 7} & -0.09 & \mathbf{- 0 . 3 3} & \mathbf{0 . 4 4} & \mathbf{0 . 3 7} & 0.07 & \mathbf{- 0 . 1 6} & \mathbf{- 0 . 1 7} & 0.06 & \mathbf{- 0 . 0 9}\end{array}$
(M) Rating (1-22)
$\begin{array}{llllllllllll}\mathbf{0 . 3 4} & \mathbf{- 0 . 3 0} & -0.48 & \mathbf{0 . 3 8} & \mathbf{- 0 . 0 2} & \mathbf{0 . 3 5} & 0.26 & \mathbf{0 . 5 9} & \mathbf{0 . 0 5} & 0.16 & \mathbf{- 0 . 2 5} & \mathbf{0 . 1 0}\end{array}$ 



\section{Chapter 6}

\section{Conclusions}

This dissertation studies the financial relevance of nonfinancial stakeholder. The traditional finance literature mainly considers the claims of investors and managers when evaluating the firm's economic circumstances, while attributing little importance to the claims of other corporate stakeholders, such as employees, customers, or suppliers. My research contributes to a body of literature that challenges this view as being too narrow, because it draws on a theory of the firm that only accounts for the presence of explicit contracts (e.g., Cornell and Shapiro, 1987; Zingales, 2000). Given that the explicit claims of nonfinancial stakeholders are generally secure when the probability of financial distress is low, they are considered to be extraneous to the valuation, corporate governance, and financing decisions of the firm. The competing view that the firm ought to be defined by its complete set of contracts (i.e., including its risky implicit agreements), has lead a growing number of researcher in finance to reconsider the role of nonfinancial stakeholders in the interpretation of classic finance problems. I conduct four empirical studies that test the influence of key nonfinancial stakeholders on the financial position and decisions of firms. In line with earlier studies, my research presents evidence that calls the prevailing assumption into question and provides additional support for the stakeholder theory of finance.

In chapter 2, I study whether employee relations influence the credit risk of firms. Consistent with the theory that employee relations affect bond investors through the influence on organizational performance and risk, I find that the quality of employment policies and practices explain the cross-sectional variation in credit risk. My analysis provides comprehensive evidence that firms with strong employee relations have a lower cost of debt financing, higher bond and long-term issuer ratings, as well as lower firm-specific risk. A onepoint increase in my measure for employee relations quality (ERI) is associated with a 2 to 4 basis points decrease in the annual yield spread of corporate bonds. I estimate that the maximum effect of employee relations on the cost of debt can reach up to 50 basis points, based on a sample of 568 U.S. public corporations between 1995 to 2006. The documented findings are robust to the inclusion of a host of control variables, alternative model specifications, endogeneity concerns, and industry membership. The outcomes of this study support the stakeholder theory of finance, by showing that employees and their human capital have a significant influence on the financial position of firms. My research contributes to the 
existing literature by demonstrating that this effect is not only relevant for equity but also bond investors.

In chapter 3, I examine whether the environmental management of borrowing firms has credit risk implications for bond investors. The results of this study support the view that the credit market concerns itself with the legal, reputational, and regulatory consequences associated with corporate environmental violations. For a sample of 582 U.S. public corporations between 1995 to 2006, I find that environmental concerns are associated with a higher cost of debt and lower credit ratings, whereas a proactive environmental engagement is associated with a lower cost of debt and higher bond ratings. The documented relation is both statistically and economically meaningful: I calculate that a standard deviation increase in my measure for environmental strengths corresponds with a reduction in the yield spread by 6 basis points. In contrast, a standard deviation increase in my measure for environmental concerns is associated with an increase in the yield spread by 5 basis points. According to a conservative estimate, the combined environmental performance effect on the cost of debt can reach as high as 64 basis points per annum. Additional tests suggest that the relation is mainly driven by climate change and regulatory issues, is not limited to high-risk industries, and has increased over the last decade. The presented findings are again robust to numerous controls for company and bond specific characteristics, alternative model specifications, and industry membership.

In chapter 4 , I contribute to the ongoing marketing-finance debate on whether customer satisfaction is associated with abnormal stock returns. I introduce two methods that are deeply rooted in the finance and accounting literature, and provide a more direct test of the errors-inexpectations hypothesis that prior studies suggest to be the source of stock mispricing. Based on my findings, I reject the hypothesis that customer satisfaction causes abnormal stock returns because of errors in investors' expectations about future earnings. While the analysis confirms that customer satisfaction positively influences the future operating performance (i.e., ROA) of firms, I find no evidence that stock market analysts systematically fail to incorporate this effect in their earnings forecasts for various time horizons (i.e., one-year, two-year, and long-term earnings growth forecasts). Furthermore, I find no significant relation between customer satisfaction and stock price changes around the earnings announcement dates of firms, which suggests that investors are not systematically surprised by the earnings implications of customer satisfaction. If the stock market would fail to correctly anticipate the effect of customer satisfaction on earnings, a correction should be observed upon the time that investors learn of their mistake.

In chapter 5, I study whether customer claims affect the capital structure decisions of firms. The stakeholder theory of corporate finance suggests that the success of customer-based strategies depends on customers' perception of how able and willing the firm is to deliver on the promises that it sells. Firms that are committed to honoring customer claims are thus expected to certify their commitment by adopting more conservative financial policies. The outcomes of my research confirm the idea that firms with a strong commitment to customer claims pursue a more conservative financial policy. For a sample of 179 U.S. public corporations over the 1995-2008 period, I find that a one-point increase in my proxy for the commitment to customer claims is associated with a 0.6 percentage point decrease in book leverage, or an equivalent 1 percentage point decrease in market leverage. Additional tests support these findings, by showing that firms with a higher commitment to customer claims are less likely to issue debt than equity when they require external financing, and more likely to repurchase debt than equity in case of financing surpluses. The documented leverage effect 
holds despite the higher debt capacity of these firms, and is robust to the inclusion of numerous controls for company characteristics and industry membership. This study thus provides supportive evidence that customers are able to influence the financial decision making of firms.

The findings presented in this dissertation, lead me to the general conclusion that nonfinancial stakeholders are able to exercise a significant influence on the financial position and decisions of modern firms. My results do not only lend support against the traditional view on the relative importance of stakeholders in financial theory, but also strengthen the foundation of other research streams that study nonfinancial stakeholder interests, such as the sustainability or marketing-finance literature. 



\section{Bibliography}

Abarbanell, J. S., Bernard, V. L., 1992. Tests of analysts' overreaction/underreaction to earnings information as an explanation for anomalous stock price behavior. Journal of Finance 47, 1181-1207.

Akerlof, G. A., Kranton, R. E., 2005. Identity and the economics of organization. Journal of Economic Perspectives 19, 9-32.

Aksoy, L., Cooil, B., Groening, C., Keiningham, T. L., Yalçin, A., 2008. The long-term stock market valuation of customer satisfaction. Journal of Marketing 72, 105-122.

Alchian, A., Demsetz, H., 1972. Production, information, costs, and economic organization. The American Economic Review 62, 777-795.

Altman, E. I., 1968. Financial ratios, discriminant analysis and the prediction of corporate bankruptcy. Journal of Finance 23, 589-609.

Altman, E. I., Rijken, H. A., 2004. How rating agencies achieve rating stability. Journal of Banking \& Finance 28, 2679-2714.

Amato, J. D., Remolona, E. M., 2003. The credit spread puzzle. BIS Quarterly Review (December), 51-63.

Anderson, E. W., 1994. Cross-category variation in customer satisfaction and retention. Marketing Letters 5, 19-30.

— 1998. Customer satisfaction and word of mouth. Journal of Service Research 1, 5-17.

Anderson, E. W., Fornell, C., Lehmann, D. R., 1994. Customer satisfaction, market share, and profitability. Journal of Marketing 56, 53-66.

Anderson, E. W., Fornell, C., Mazvancheryl, S. K., 2004. Customer satisfaction and shareholder value. Journal of Marketing 68, 172-185.

Anderson, E. W., Fornell, C., Rust, R. T., 1997. Customer satisfaction, productivity, and profitability: Differences between goods and services. Marketing Science 16, 129-145.

Anderson, R. C., Mansi, S. A., 2009. Does customer satisfaction matter to investors? Findings from the bond market. Journal of Marketing Research 46, 703-714.

Anderson, R. C., Mansi, S. A., Reeb, D. M., 2003. Founding family ownership and the agency cost of debt. Journal of Financial Economics 68, 263-285.

- 2004. Board characteristics, accounting report integrity, and the cost of debt. Journal of Accounting and Economics 37, 315-342. 
Arellano, M., Bover, O., 1995. Another look at the instrumental variable estimation of errorcomponents models. Journal of Econometrics 68, 29-51.

Ashbaugh, H., Collins, D. W., LaFond, R., 2004. Corporate governance and the cost of equity capital. Working Paper: University of Wisconsin, Madison; University of Iowa.

Ashbaugh-Skaife, H., Collins, D. W., LaFond, R., 2006. The effects of corporate governance on firms' credit ratings. Journal of Accounting and Economics 42, 203-243.

Baker, G., Gibbons, R., Murphy, K. J., 2002. Relational contracts and the theory of the firm. Quarterly Journal of Economics 117, 39-84.

Baker, M., Wurgler, J., 2002. Market timing and capital structure. Journal of Finance 42, 1-32.

Balkenborg, D., 2001. How liable should a lender be? The case of judgment-proof firms and environmental risk: Comment. American Economic Review 91, 731-738.

Banerjee, S., Dasgupta, S., Kim, Y., 2008. Buyer-supplier relationships and the stakeholder theory of capital structure. Journal of Finance 63, 2507-2552.

Barth, M. E., McNichols, M. F., Wilson, P., 1997. Factors influencing firms' disclosures about environmental liabilities. Review of Accounting Studies 2, 35-64.

Barth, M., McNichols, M., 1994. Estimation and market valuation of environmental liabilities relating to superfund sites. Journal of Accounting Research 32, 177-209.

Barton, S. L., Hill, N. C., Sundaram, S., 1989. An empirical test of stakeholder theory predictions of capital structure. Financial Management 18, 36-44.

Bebchuk, L., Cohen, A., Ferrell, A., 2009. What matters in corporate governance? Review of Financial Studies 22, 783-827.

Berger, P. G., Ofek, E., Yermack, D. L., 1997. Managerial entrenchment and capital structure decisions. Journal of Finance 52, 1411-1438.

Bhojraj, S., Sengupta, P., 2003. Effect of corporate governance on bond ratings and yields: The role of institutional investors and outside directors. Journal of Business 76, 455-475.

Blacconiere, W. G., Northcut, W. D., 1997. Environmental information and market reactions to environmental legislation. Journal of Accounting, Auditing \& Finance 14,149-178.

Blundell, R., Bond, S., 1998. Initial conditions and moment restrictions in dynamic panel-data models. Journal of Econometrics 87, 115-143.

Boatright, J. R., 2002. Contractors as stakeholders: Reconciling stakeholder theory with the nexus-of-contracts firm. Journal of Banking \& Finance 26, 1837-1852.

Bolton, R. N., 1998. A dynamic model of the duration of the customer's relationship with a continuous service provider: The role of satisfaction. Marketing Science 17, 45-65.

Bolton, R. N., Drew, J. H., 1991. A longitudinal analysis of the impact of service changes on customer attitudes. Journal of Marketing 55, 1-9.

Boyer, M., Laffont, J. J., 1995. Environmental protection, producer insolvency, and lender liability. In A. Xepapadeas, ed., Economic policy for the environment and natural resources. Northampton, Mass.: Edward Elgar, 1996. 
, 1997. Environmental risks and bank liability. European Economic Review 41, 14271459.

Bradford, W. D., 2005. Discrimination, legal costs and reputational costs. Working Paper: University of Washington.

Bradley, M., Chen, D., Dallas, G. S., Snyderwine, E., 2008. The effects of corporate governance attributes on credit ratings and bond yields. Working Paper: Duke University.

Bradshaw, M. T., Richardson, S. A., Sloan, R. G., 2001. Do analysts and auditors use information in accruals? Journal of Accounting Research 39, 45-74.

Bronars, S. G., Deere, D. R., 1991. The threat of unionization, the use of debt, and the preservation of shareholder wealth. Quarterly Journal of Business and Economics 106, 231-254.

Bushee, B. J., Noe, C. F., 2000. Corporate disclosure practices, institutional investors, and stock return volatility. Journal of Accounting Research 38, 171-202.

Campbell, J.Y., Taksler, G.B., 2003. Equity volatility and corporate bond yields. Journal of Finance 58, 2321-2349.

Carhart, M. M., 1997. On persistence in mutual fund performance. Journal of Finance 52, 5782.

Chava, S., 2010. Do environmental concerns affect the cost of bank loans? Working paper: Georgia Institute of Technology - College of Management.

Chava, S., Livdan, D., Purnanandam, A. K., 2008. Do shareholder rights affect the cost of bank loans? Review of Financial Studies 22, 2973-3004.

Chen, H.J., Kacperczyk, M., Ortiz-Molina, H., 2010. Do nonfinancial stakeholders affect the pricing of risky debt? Evidence from unionized workers. Review of Finance, forthcoming.

, 2010. Labor unions, operating flexibility, and the cost of equity. Journal of Financial and Quantitative Analysis, forthcoming.

Chen, L. K. C., Jegadeesh, N., Lakonishok, J., 1996. Momentum strategies. Journal of Finance 51, 1681-1713.

Cheung, Y., Ng, L., 1992. Stock price dynamics and firm size: An empirical investigation. Journal of Finance 47, 1985-1997.

Clarkson, P., Li, Y., Richardson, G., 2004. The market valuation of environmental capital expenditures by pulp and paper companies. The Accounting Review 79, 329-353.

Cohen, A., 1962. Yields on new underwritten corporate bonds. Journal of Finance 42, 585605.

Connolly, R. A., Hirsch, B. T., Hirschey, M., 1986. Union rent seeking, intangible capital, and market value of the firm. Review of Economics and Statistics 68, 567-577.

Cooil, B., Keiningham, T. L., Aksoy, L., Hsu, M., 2007. A longitudinal analysis of customer satisfaction and share of wallet: Investigating the moderating effect of customer characteristics. Journal of Marketing 71, 67-83. 
Core, J. E., Guay, W. R., Rusticus, T. O., 2006. Does weak governance cause weak stock returns? An examination of firm operating performance and investors' expectations. Journal of Finance 61, 655-687.

Cormier, D., Magnan, M., 1997. Investors' assessment of implicit environmental liabilities: An empirical investigation. Journal of Accounting and Public Policy 16, 215-241.

Cornell, B., Shapiro, A. C., 1987. Corporate stakeholders and corporate finance. Financial Management 16, 5-14.

Cremers, K. J., Nair, V. B., Wei, C., 2007. Governance mechanisms and bond prices. Review of Financial Studies 20, 1359-1388.

Cremers, K. M., Petajisto, A., Zitzewitz, E., 2009. Should benchmark indices have alpha? Revisiting performance evaluation. Working Paper: Yale School of Management.

Cronqvist, H., Heyman, F., Nilsson, M., Svaleryd, H., Vlachos, J., 2009. Do entrenched managers pay their workers more? Journal of Finance 64, 309-339.

Dai, Z., Zhang, W., Jin, L., 2008. Litigation risk and executive compensation. Working Paper: University of Texas, Harvard Business School.

Datta, S., Iskandar-Datta, M., Patel, A., 1999. Bank monitoring and the pricing of corporate public debt. Journal of Financial Economics 51, 435-449.

De Jong, A., Kabir, R., Nguyen, T., 2008. Capital structure around the world: the roles of firmand country-specific determinants. Journal of Banking \& Finance 32, 1954-1969.

Dechow, P. M., Hutton, A. P., Sloan, R. G., 2000. The relation between analysts' forecasts of long-term earnings growth and stock price performance following equity offerings. Contemporary Accounting Research 17, 1-32.

Derwall, J., Guenster, N., Bauer, R., Koedijk, K., 2005. The eco-efficiency premium puzzle. Financial Analyst Journal 61, 51-63.

Doukas, J. A., Kim, C. F., Pantzalis, C., 2002. A test of the errors-in-expectations explanation of the value/glamour stock returns performance: Evidence from analysts' forecasts. Journal of Finance 57, 2143-2165.

Dwyer, F. R., Schurr, P. H., Sejo, O., 1987. Developing buyer-seller relationships. Journal of Marketing 51, 11-27.

Edmans, A. 2011. Does the market fully value intangibles? Employee satisfaction and equity prices. Journal of Financial Economics, forthcoming.

Engelmann, K., Cornell, B., 1988. Measuring the cost of corporate litigation: Five case studies. Journal of Legal Studies 17, 377-399.

Faleye, O., Mehrotra, V., Morck, R., 2006. When labor has a voice in corporate governance. Journal of Financial and Quantitative Analysis 41, 489-510.

Faleye, O., Trahan, E. A., 2006. Is what's best for employees best for shareholders? Working Paper: Northeastern University.

Fama, E. F., Jensen, M. C., 1983a. Separation of ownership and control. Journal of Law and Economics 26, 301-326. 
, 1983b. Agency problems and residual claims. Journal of Law and Economics 26, 327-350.

Fama, E. F., French, K. R., 1993. Common risk factors in the returns on stocks and bonds. Journal of Financial Economics 33, 3-56.

, 1995. Size and book-to-market factors in earnings and returns. Journal of Finance 50, $131-155$.

— 2000. Forecasting profitability and earnings. Journal of Business 73, 161-175.

, 2002. Testing trade-off and pecking order predictions about dividends and debt. Review of Financial Studies 15, 1-33.

Federal Reserve Board, New Security Issues, U.S. Corporations. Statistical Supplement to the Federal Reserve Bulletin, December 2006.

http://www.federalreserve.gov/pubs/supplement/2006/12/table1_46.htm

Filbeck, G., Preece, D., 2003. Fortune's best 100 companies to work for in America: Do they work for shareholders? Journal of Business Finance \& Accounting 30, 771-797.

Fisher, L., 1959. Determinants of risk premiums on corporate bonds. Journal of Political Economy 88, 288-307.

Fisman, R., Heal, G., Nair, V. B., 2006. A model of corporate philantrophy. Working Paper: Wharton School, University of Pennsylvania.

Fornell, C., 1992. A national customer satisfaction barometer: The Swedish experience. Journal of Marketing 56, 6-21.

Fornell, C., Johnson, M. D., Anderson, E. W., Cha, J., Bryant, B. E., 1996. The American Customer Satisfaction Index: Nature, purpose, and findings. Journal of Marketing 60, $7-$ 18.

Fornell, C., Mithas, S., Morgeson III, F. V., 2009a. The economic and statistical significance of stock returns on customer satisfaction. Marketing Science 2, 820-825.

- 2009b. The statistical significance of portfolio returns. International Journal of Research in Marketing 26, 162-163.

Fornell, C., Mithas, S., Morgeson III, F. V., Krishnan, M. S., 2006. Customer satisfaction and stock prices: High returns, low risk. Journal of Marketing 70, 3-14.

Frank, M. Z., Goyal, V. K., 2009. Capital structure decisions: Which factors are reliably important? Financial Management 38, 1-37.

Freeman, R.E., Harrison, J.S., Wicks, A.C., Parmar, B.L., Colle, S., de, 2010. Stakeholder theory. The state of the art. Cambridge University Press, 344.

Gamble, G. O., Hsu, K., Kite, D., Radtke, R. R., 1995. Environmental disclosures in annual reports and 10Ks: An examination. Accounting Horizons 9, 34-54.

Garber, S., Hammitt, J. K., 1998. Risk premiums for environmental liability: Does Superfund increase the cost of capital? Journal of Environmental Economics and Management 36, 267-294. 
Gaspar, J.-M., Massa, M., 2006. Idiosyncratic volatility and product market competition. Journal of Business 79, 3125-3152

Gennard, J., Hayward, G., 2004. Employee relations revision guide 2005. Chartered Institute of Personnel and Development, 2nd edition.

Gibbons, R., 1998. Incentives in organizations. Journal of Economic Perspectives 12, 115-132.

Gompers, P., Ishii, J., Metrick, A., 2003. Corporate governance and equity prices. Quarterly Journal of Economics 118, 107-155.

Goss, A., Roberts, G. S., 2010. The impact of corporate social responsibility on the cost of bank loans. Journal of Banking \& Finance, forthcoming.

Graham, A., Maher, J. J., 2006. Environmental liabilities, bond ratings, and bond yields. Advances in Environmental Accounting \& Management 3, 111-142.

Graham, A., Maher, J. J., Northcut, W. D., 2001. Environmental liability information and bond ratings. Journal of Accounting, Auditing and Finance 15, 96-116.

Graves, S. B., Waddock, S. A., 1994. Institutional ownership and corporate social performance. Academy of Management Journal 37, 1034-1046.

Greenberg, M. I., Shaw, D. M., 1991. To lend or not to lend - that should not be the question: The uncertainties of lender liability under CERCLA. 41 Duke L.J. 1211

Grinblatt, M., Titman, S., 1998. Financial markets and corporate strategy. New York: McGrawHill/Irwin, 2nd edition.

Gruca, T. S., Rego, L. L., 2005. Customer satisfaction, cash flow, and shareholder value. Journal of Marketing 69, 115-130.

Hammond, R. G., 2010. Quantifying consumer perception of a financially distressed company. Working Paper: North Carolina State University.

Hanssens, D. M., Rust, R. T., Srivastava, R. K., 2009. Marketing strategy and Wall Street: Nailing down marketing's impact. Journal of Marketing 73, 115-118.

Hertzberg, F., 1959. The motivation to work. New York: John Wiley \& Sons.

Heyes, A. G., 1996. Lender penalty for environmental damage and the equilibrium cost of capital. Economica 63, 311-323.

Hirsch, B. T., Macpherson, D. A., 2003. Union membership and coverage database from the current population survey: Note. Industrial and Labor Relations Review 56, 349-354.

Holder, M. E., Langrehr, F. W., Hexter, J. L., 1998. Dividend policy determinants: An investigation of the influences of stakeholder theory. Financial Management 27, 73-82.

Horrigan, J., 1966. The determinants of long-term credit standing with financial ratios. Journal of Accounting Research 4, 44-62.

Hovakimian, A., Hovakimian, G., Tehranian, H., 2004. Determinants of target capital structure: The case of dual debt and equity issues. Journal of Financial Economics 71, 517-540.

Hovakimian, A., Opler, T., Titman, S., 2001. The debt-equity choice. Journal of Financial and Quantitative Analysis 36, 1-24. 
Huselid, M. A., 1995. The impact of human resource management practices on turnover, productivity, and corporate financial performance. Academy of Management Journal 38, 635-672.

Ichnioswki, C., Shaw., K., 1999. The effects of human resource management systems on economic performance: An international comparison of U.S. and Japanese plants. Management Science 45, 704-721.

Ichniowski, C., Shaw, K., Prennushi, G., 1997. The effects of human resource management practices on productivity: A study of steel finishing lines. The American Economic Review 87, 291-313.

Ittner, C. D., Larcker, D. F., 1998. Are nonfinancial measures leading indicators of financial performance? An analysis of customer satisfaction. Journal of Accounting Research 36, 135 .

Ittner, C. D., Larcker, D. F., Taylor, D. J., 2009. The stock market's pricing of customer satisfaction. Marketing Science 28, 826-835

Jacobson, R., Mizik, N., 2009a. The financial markets and customer satisfaction: Re-examing possible financial market mispricing of customer satisfaction. Marketing Science 28, 810 819.

- 2009b. Customer satisfaction-based mispricing: Issues and misconceptions. Marketing Science 28, 835-844.

Jensen, M. C., Meckling, W. H., 1976. Theory of the firm: managerial behavior, agency costs and ownership structure. Journal of Financial Economics 3, 306-360

John, K., Litov, L., Yeung, B., 2008. Corporate governance and managerial risk taking. Journal of Finance 63, 1679-1728.

Johnson, R. A., Greening, D. W., 1999. The effects of corporate governance and institutional ownership types on corporate social performance. Academy of Management Journal 42, $564-576$.

Jones, E.P., Mason, S., Rosenfeld, E., 1984. The contingent claims analysis of corporate capital structures: An empirical investigation. Journal of Finance 39, 611-625.

Kale, J. R., Shahrur, H., 2007. Corporate capital structure and the characteristics of suppliers and customers. Journal of Financial Economics 83, 265-321.

Kane, G. D., Velury, U., Ruf, B. M., 2005. Employee relations and the likelihood of occurrence of corporate financial distress. Journal of Business Finance and Accounting 32, 10831105 .

Kaplan, R., Urwitz, G., 1979. Statistical models of bond ratings: A methodological inquiry. Journal of Business 52, 231-261.

Karpoff, J. M., Lott, J. R., 1999. On the determinants and importance of punitive damage awards. Journal of Law and Economics 42, 527-573.

Keiningham, T. L., Perkins-Munn, T., Evans, H., 2003. The impact of customer satisfaction on share-of-wallet in a business-to-business environment. Journal of Service Research 6, 3750 . 
Kempf, A., Osthoff, P., 2007. The effect of socially responsible investing on portfolio performance. European Financial Management 13, 908-922.

Kimbrough, M. D., McAlister, L., 2009. Linking marketing actions to value creation and firm value: Insights from accounting research. Journal of Marketing Research 46, 313-329.

King, A. A., Lennox, M. D., 2002. Exploring the locus of profitable pollution reduction. Management Science 48, 289-299.

Kisgen, D. K., 2006. Credit ratings and capital structure. Journal of Finance 61, 1035-1072.

— 2009. Do firms target credit ratings or leverage levels? Journal of Financial and Quantitative Analysis 44, 1323-1344.

Kishiyama, L. T., 2003. Countering corporate evasion of environmental obligations through bankruptcy. Roscoe Hogan Environmental Law Essay Contest.

Klassen, R. D., McLaughlin, C. P., 1996. The impact of environmental management on firm performance. Management Science 42, 1199-1214.

Klassen, R. D., Whybark, D. C., 1999. The impact of environmental technologies on manufacturing performance. Academy of Management Journal 42, 599-615.

Klein, B., Crawford, R. G., Alchian, A. A., 1978. Vertical Integration, appropriable rents, and the competitive contracting process. Journal of Law and Economics 21, 297-326.

Klock, M. S., Mansi, S. A., Metrick, W. F., 2005. Does corporate governance matter to bondholders? Journal of Financial and Quantitative Analysis 40, 693-719.

Koehler, D. A., Spengler, J. D., 2007. The toxic release inventory: Fact or fiction? A case study of the primary aluminum industry. Journal of Environmental Management 85, 296-307.

Konar, S., Cohen, M. A., 2001. Does the market value environmental performance. Review of Economics and Statistics 83, 281-289.

Kothari, S. P., 2001. Capital markets research in accounting. Journal of Accounting and Economics 31, 105-231.

Kroszner, R. S., Strahan, P. E., 2001. Bankers on boards: monitoring, conflicts of interest, and lender liability. Journal of Financial Economics 62, 415-452.

La Porta, R., 1996. Expectations and the cross-section of stock returns. Journal of Finance 51, $1715-1742$.

La Porta, R., Lakonishok, J., Shleifer, A., Vishny, R. W., 1997. Good news for value stocks: Further evidence on market efficiency. Journal of Finance 52, 859-874.

Lamy, R., Thompson, R., 1988. Risk premia and the pricing of primary issue bonds. Journal of Banking and Finance 12, 585-601.

Leat, M., 2001. Exploring employee relations. Oxford: Butterworth-Heinemann.

Lehman, B., Modest, D., 1987. Mutual fund performance evaluation: A comparison of benchmarks and benchmark comparisons. Journal of Finance 42, 233-265.

Lipson, M. L., Mortal, S., 2009. Liquidity and capital structure. Journal of Financial Markets $12,611-644$. 
Luck, C. G., Pilotte, N., 1993. Domini Social Index Performance. Journal of Investing 2, 60 62.

Mackie-Mason, J. K., 1990. Do taxes affect corporate financing decisions? Journal of Finance $45,1471-1493$.

Maksimovic, V., Titman, S., 1991. Financial policy and reputation for product quality. Review of Financial Studies 4, 175-200.

Maslow, A., 1943. A theory of human motivation. Psychological Review 50, 370-396.

Mattingley, J. E., Berman, S. L., 2006. Measurement of corporate social action - Discovering taxonomy in the Kinder Lydenburg Domini ratings data. Business \& Society 45, 20-46.

McGregor, D., 1960. The human side of enterprise. New York: McGraw-Hill.

McKenzie, G., Wolfe, S., 2004. The impact of environmental risk on the UK banking sector. Applied Financial Economics 14, 1005-1016.

Merton, R. C., 1974. On the pricing of corporate debt: The risk structure of interest rates. Journal of Finance 29, 449-470.

Miller, J. G., Kahn, B., 2003. Analyzing employment practices liability insurance: Employers must manage the risk of lawsuits related to employment practices. Compensation \& Benefits Review 35, 38-45.

Mithas, S., Krishnan, M. S., Fornell, C., 2005. Why do customer relationship management applications affect customer satisfaction? Journal of Marketing 69, 201-209.

Mittal, V., Kamakura, W. A., 2001. Satisfaction, repurchase intent, and repurchase behavior: investigating the moderating effect of customer characteristics. Journal of Marketing Research 38, 131-142.

Morgan, N. A., Rego, L. L., 2006. The value of different customer satisfaction and loyalty metrics in predicting business performance. Marketing Science 25, 426-439.

O’Sullivan, D., Hutchinson, M., O’Connell, V., 2009. Empirical evidence of the stock markets (mis)pricing of customer satisfaction. International Journal of Research in Marketing 26, 154-161.

Opler, T. C., Titman, S., 1994. Financial distress and corporate performance. Journal of Finance 49, 1015-1040.

Ortiz-Molina, H., 2006. Top-management incentives and the pricing of corporate public debt. Journal of Financial and Quantitative Analysis 41, 317-340.

Pagano, M., Volpin, P. F., 2005. Managers, workers, and corporate control. Journal of Finance $60,841-868$.

Penman, S. H., 1992. Financial statement information and the pricing of earnings changes. The Accounting Review 67, 563-577.

Petersen, M. A., 2009. Estimating standard errors in finance panel data sets: Comparing approaches. Review of Financial Studies 22, 435-480.

Pfeffer, J., 1996. Competitive advantage through people: Unleashing the power of the work force. Cambridge: Harvard Business School Press. 
Pitchford, R., 1995. How liable should a lender be? The case of judgment-proof firms and environmental risk. The American Economic Review 85, 1171-1186.

__ 2001. How liable should a lender be? The case of judgment-proof firms and environmental risk: Reply. The American Economic Review 91, 739-745.

Prendergast, C., 1999. The provision of incentives in firms. Journal of Economic Literature 37, 7-63.

Qui, J., Yu, F., 2008. The market for corporate control and the cost of debt. Journal of Financial Economics 93, 505-524.

Rajan, R. G., Zingales, L., 1995. What do we know about capital structure? Some evidence from international data. Journal of Finance 50, 1421-1460.

- 1998. Power in a theory of the firm. Quarterly Journal of Economics 113, 387-432.

Reinartz, W., Krafft, M., Hoyer, W. D., 2004. The customer relationship management process: its measurement and impact on performance. Journal of Marketing Research 41, 293-305.

Reinhardt, F., 1999. Market failure and the environmental policies of firms. Journal of Industrial Ecology 3, 9-21.

Richardson, S., Teoh, S. H., Wysocki, P. D., 2004. The walkdown to beatable analyst forecasts: The roles of equity issuance and insider trading incentives. Contemporary Accounting Research 21, 885-924.

Roll, R. 1977. A critique of the asset pricing theory's tests part I: On past and potential testability of the theory, Journal of Financial Economics 4, 129-176.

Ruback R. S., Zimmerman, M. B., 1984. Unionization and profitability: Evidence from the capital market. Journal of Political Economy 92, 1134-1157.

Russo, M., Fouts, P. A., 1997. A resource-based perspective on corporate environmental performance and profitability. Academy of Management Journal 40, 534-559.

Schneider, T., 2010. Is environmental performance a determinant of bond pricing? Evidence from the U.S. pulp and paper and chemical industries. Contemporary Accounting Research, forthcoming.

Sharfman, M. P., Fernando, C. S., 2008. Environmental risk management and the cost of capital. Strategic Management Journal 29, 569-592.

Sharpe, W. F., 1964. Capital asset prices: A theory of market equilibrium under conditions of risk. Journal of Finance 19, 425-442.

Singh, J., Sirdeshmukh, D., 2000. Agency and trust mechanisms in consumer satisfaction and loyalty judgments. Journal of the Academy of Marketing Science 28, 150-167.

Skinner, D. J., Sloan, R. G., 2002. Earnings surprises, growth expectations, and stock returns or don't let an earnings torpedo sink your portfolio. Review of Accounting Studies 7, 289-312.

Srinivasan, S., Hanssens, D. M., 2009. Marketing and firm value: Metrics, methods, findings, and future directions. Journal of Marketing Research 46, 293-312.

Standard and Poor's, 2008. Corporate ratings criteria.

www.corporatecriteria.standardandpoors.com 
Statman, M., Glushkov, D., 2009. The wages of social responsibility. Financial Analysts Journal 65, 33-46.

Titman, S., 1984. The effect of capital structure on a firm's liquidation decision. Journal of Financial Economics 13, 1-19.

Titman, S., Wessels, R., 1988. The determinants of capital structure choice. Journal of Finance $43,1-19$.

Toffel, M. W., Marshall, J. D., 2008. Improving environmental performance assessment: A comparative analysis of weighting methods used to evaluate chemical release inventories. Journal of Industrial Ecology 8, 143-172.

Tuli, K. R., Bharadwaj, S. G., 2009. Customer satisfaction and stock returns risk. Journal of Marketing 73, 184-197.

Turnley, W. H., Feldman, D. C., 1999. The impact of psychological contract violations on exit, voice, loyalty, and neglect. Human Relations 52, 895-922.

U.S. Department of Justice, Office of Justice Programs, Bureau of Justice Statistics, 2002. Civil Justice Data Brief: http://www.ojp.usdoj.gov/bjs/abstract/crcus00.htm.

U.S. Equal Employment Opportunity Commission. All Statutes. FY 1992 - FY 2006: http://www.eeoc.gov/stats/all.html.

Verwijmeren, P., Derwall, J., 2009. Employee well-being, firm leverage, and bankruptcy risk. Journal of Banking \& Finance 34, 956-964.

Waddock, S. A., Graves, S. B., 1997. The corporate social performance-financial performance link. Strategic Management Journal 18, 303-319.

Welsh, I., 2004. Capital structure and stock returns. Journal of Political Economy 112, 106131.

West, R., 1970. An alternative approach to predicting corporate bond ratings. Journal of Accounting Research 7, 118-127.

Windmeijer, F., 2005. A finite sample correction for the variance of linear efficient two-step GMM estimators. Journal of Econometrics 126, 25-51.

Ziebart, D., Reiter, S., 1992. Bond ratings, bond yields and financial information. Contemporary Accounting Research 9, 252-282.

Zingales, L., 2000. In search of new foundations. Journal of Finance 55, 1623-1653 



\section{Nederlandse Samenvatting}

De traditionele financiële literatuur veronderstelt vaak dat alleen het management en de aandeelhouders relevant zijn voor de waardering, corporate governance en de financiering van een onderneming en dat de andere stakeholders dit niet zijn. Mijn proefschrift draagt bij aan de literatuurstroming die deze opvatting tegengaat en de non-financiële stakeholders een belangrijke rol toedicht op het gebied van bedrijfsstrategie en bedrijfsfinanciering (e.g., Cornell en Shapiro, 1987; Zingales, 2000; Baker, Gibbons, en Murphy, 2002). Ik verricht vier empirische studies die de invloed van de cruciale non-financiële stakeholders op de financiële situatie en besluitvorming van een onderneming toetsen. In overeenstemming met eerdere studies toont mijn onderzoek aan dat de toonaangevende stelling betwistbaar is. Tevens levert mijn onderzoek aanvullend bewijs voor de stakeholder theorie op het gebied van financiering.

In hoofdstuk 2 onderzoek ik of arbeidsverhoudingen invloed hebben op het kredietrisico van ondernemingen. In overeenstemming met de theorie dat arbeidsverhoudingen obligatiebeleggers beïnvloeden door middel van het effect dat arbeidsverhoudingen hebben op organisatorische prestatie en risico, neem ik waar dat de cross-sectionele variatie in kredietrisico verklaard wordt door de kwaliteit van het personeelsbeleid. Mijn analyse toont aan dat ondernemingen met betere arbeidsverhoudingen lagere kredietkosten, een hogere kredietwaardigheid, als ook een lager bedrijfsspecifiek risico laten zien. Een stijging van één punt in mijn variabele voor de kwaliteit van arbeidsverhoudingen (ERI) leidt tot een daling van het jaarlijks renteverschil van bedrijfsobligaties met 2 tot 4 basispunten. Ik raam, gebaseerd op een steekproef van 568 Amerikaanse beursgenoteerde ondernemingen over de periode 1995 tot 2006, het maximaal effect dat arbeidsverhoudingen hebben op de kredietkosten op 50 basispunten. Mijn bevindingen zijn robuust voor het meenemen van verschillende controle variabelen, alternatieve model specificaties, endogeniteit kwesties, en industrie-effecten. De resultaten van deze studie steunen de stakeholder theorie op het gebied van financiering, door aan the tonen dat werknemers en hun human capital een significant effect hebben op de financiële situatie van ondernemingen.

In hoofdstuk 3 onderzoek ik of het milieumanagement van lenende ondernemingen consequenties heeft voor het kredietrisico dat obligatiebeleggers lopen. De resultaten van het onderzoek ondersteunen de opvatting dat kredietmarkten de juridische, reputatie, en regelgevende gevolgen van bedrijfsmatige milieuovertredingen in overweging nemen. Ik constateer dat, gebaseerd op een steekproef van 582 Amerikaanse beursgenoteerde ondernemingen over de periode 1995 tot 2006, milieuproblemen worden geassocieerd met hogere kredietkosten en lagere kredietwaardigheid, terwijl proactief milieumanagement geassocieerd wordt met lagere kredietkosten en hogere kredietwaardigheid. Deze relatie is zowel statistisch en economisch betekenisvol. Een standaard deviatie verhoging van mijn variabele, voor goed 
milieumanagement, komt overeen met een daling van het renteverschil met 6 basispunten. Een standaard deviatie verhoging van mijn variabele voor milieuproblematiek, komt echter overeen met een stijging van het renteverschil met 5 basispunten. Volgens een conservatieve schatting kan het effect van de gecombineerde milieuprestatie op de kredietkosten oplopen tot 64 basispunten per jaar. Aanvullende analyses geven aan dat dit effect voornamelijk gedreven wordt door klimaatverandering en regelgevingkwesties, zich niet beperkt tot industrieën met een hoog risico, en is toegenomen over het laatste decennium. De resultaten zijn opnieuw robuust na het meenemen van verschillende controle variabelen, alternatieve model specificaties, endogeniteit kwesties, en industrie-effecten.

In hoofdstuk 4 draag $\mathrm{ik}$ bij aan de lopende marketing-finance discussie of klanttevredenheid in relatie staat met abnormale aandelenrendementen. Ik introduceer twee methoden die diep geworteld zijn in de financiering en accounting literatuur en een meer directe test die de fouten-in-verwachtingen hypothese toetst die in voorgaande onderzoeken aangedragen wordt als de oorzaak van het misprijzen van aandelen. Gebaseerd op mijn bevindingen verwerp ik de hypothese dat klanttevredenheid de oorzaak is, doordat beleggers foute verwachtingen hebben van toekomstige bedrijfsresultaten, van abnormale aandelenrendementen. Het onderzoek bevestigt dat klanttevredenheid de operationele prestatie (i.e., rentabiliteit van het totaal vermogen) van ondernemingen positief beïnvloed. Ik vind echter geen bewijs, over verschillende tijdsperioden (i.e., één jaar, twee jaar en lange termijn winstverwachtingen), dat beursanalisten er systematisch niet in slagen om dit effect op te nemen in hun winstverwachtingen. Verder vind ik geen significante relatie tussen klanttevredenheid en veranderingen in de aandelenkoers rond de datum dat het bedrijfsresultaat bekend wordt gemaakt. Dit suggereert dat beleggers niet systematisch verrast zijn door het effect dat klanttevredenheid heeft op het bedrijfsresultaat. Als de aandelenmarkt er niet in zou slagen om correct te anticiperen op het effect dat klanttevredenheid heeft op het bedrijfsresultaat dan zou er, op het moment dat beleggers hun fout inzien, een correctie waargenomen moeten worden.

In hoofdstuk 5 onderzoek ik of klantenclaims invloed hebben op de besluitvorming van ondernemingen betreffende de kapitaalstructuur. De stakeholder theorie, op het gebied van corporate finance, houdt in dat het succes van klantgerichte strategieën afhangt van hoe klanten de bekwaamheid en de bereidheid van ondernemingen om hun beloftes na te komen beoordelen. De verwachting is dat ondernemingen die bereid zijn om de claims van hun klanten te erkennen een conservatiever financieel beleid voeren. De resultaten van mijn onderzoek bevestigen de theorie dat ondernemingen die klantenclaims goed afhandelen een conservatiever financieel beleid voeren. Ik constateer dat, gebaseerd op een steekproef van 176 Amerikaanse beursgenoteerde ondernemingen over de periode 1995 tot 2008, dat als mijn variabele, voor het afhandelen van klantenclaims, toeneemt met één punt zich dit vertaalt in een daling in boek leverage met 0,6 procentpunt of een daling in markt leverage met 1 procentpunt. Aanvullende analyses bevestigen deze bevindingen, voor ondernemingen die klantenclaims beter afhandelen is een obligatie-emissie waarschijnlijker als er een financieringtekort is dan een aandelenemissie. Verder kopen ondernemingen die klantenclaims beter afhandelen eerder obligaties terug als er sprake is van een financieel overschot dan aandelen. Ondanks de grotere schuldcapaciteit van deze ondernemingen heeft dit invloed op leverage en zijn de resultaten robuust na het meenemen van verschillende controle variabelen en industrie-effecten. Dit onderzoek levert bewijs dat klanten in staat zijn om de financieringsbeslissingen van ondernemingen te beïnvloeden. 
Op basis van de bevindingen gepresenteerd in dit proefschrift concludeer ik dat nietfinanciële stakeholders in staat zijn om significante invloed uit te oefenen op de financiële situatie en besluitvorming van een moderne onderneming. Mijn resultaten onderschrijven dat de traditionele opvatting betreffende het relatieve belang van stakeholders op het gebied van financiering niet juist is. Daarnaast ondersteunen mijn bevindingen andere onderzoeksstromen die de belangen van niet-financiële stakeholders bestuderen, zoals de duurzaamheid en de marketing-finance literatuur. 



\section{Curriculum Vitae}

Daniel Hann was born on September 9, 1980, in Seoul, South Korea. He attended his secondary school education at the Dietrich Bonhoeffer Gymnasium in Bergisch Gladbach, Germany, where he also obtained his general qualification for university entrance in 2000. After fulfilling his civilian service duties, he enrolled at the Maastricht University School of Business and Economics in 2001 to follow the International Management track with an emphasis on finance and corporate strategy. Next to his studies, Daniel worked for a term at Stilcken+Goettges, a consulting agency for corporate communication in Hamburg, Germany; and in the German automotive sector for Porsche Engineering Services in Weissach. In 2005, he participated in an academic exchange to Yonsei University in Seoul, South Korea. During the second half of his university education, Daniel developed a particular interest in financial theory, which he further pursued in his master thesis that is titled "Corporate Governance and Credit Risk: Testing the Impact of Governance Structures on Credit Default Swap Premia". He graduated from Maastricht University in 2006 with a M.Sc. in Economics.

Following his studies, Daniel joined the Finance Department at Maastricht University as Ph.D. candidate in September 2006. His position was supervised by Prof. Dr. Rob Bauer and co-supervised by Dr. Jeroen Derwall. Parts of his doctoral research were sponsored by Mistra, the Swedish foundation for strategic environmental research. During his time as $\mathrm{Ph} . \mathrm{D}$. candidate, he gathered extensive teaching experience in finance courses at the bachelor and master level. He has also supervised numerous Master's theses at Maastricht University and functioned as an external thesis examiner for MBA students at the University of Cape Town. In 2010, Daniel was offered the opportunity to conduct part of his research as visiting scholar at the Finance Department of the New York University Stern School of Business.

Daniel's research has been presented at various conferences and seminars, such as the $5^{\text {th }}$ Corporate Finance Day at Université Catholique, ECCE SRI/CSR Conference, ECCE / UN PRI Conference, Harvard Law School Labor and Human Rights Conference, Marketing Science Conference, NYU Stern School of Business Corporate Governance Research Luncheon, oikos PRI Young Scholars Finance Academy, SRI in the Rockies Conference, The Academy of Management Meetings, The American Accounting Association Meetings, and Toulouse School of Economics SRI Conference. Next to his academic engagements, Daniel has also presented his work in seminars and workshops at professional institutions, including APG Fixed Income Management, Deutsche Asset Management, DB Advisors, Nordea Bank, SEB Bank, Sustainable Asset Management (SAM), and SWESIF. His work on the credit risk implications of corporate environmental management has been awarded the 2010 Moskowitz Prize for Best Paper in the Socially Responsible Investing domain by the Haas School of Business, University of California at Berkeley and the Social Investment Forum.

Alongside his university appointment, Daniel had and continues to have a research affi- 
liation with the European Centre for Corporate Engagement (ECCE), an internationally oriented research consortium that is devoted to delivering academic and practitioner-oriented research in the fields of corporate engagement and sustainable finance. He will start working for DWS Investments GmbH in Frankfurt, Germany, in July 2011. 